
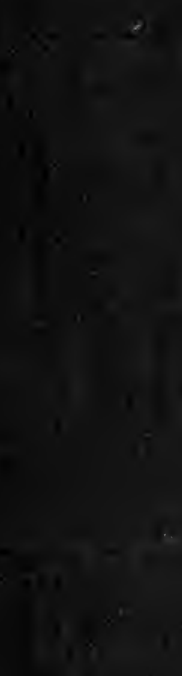
From the collection of the

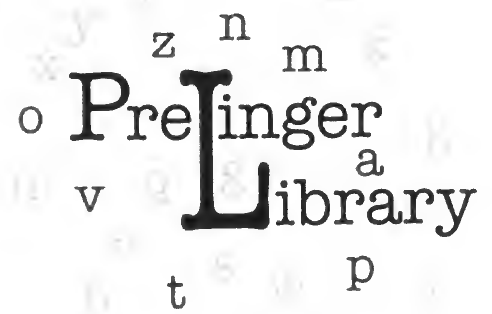

San Francisco, California 2006 


$$
\text { , }
$$





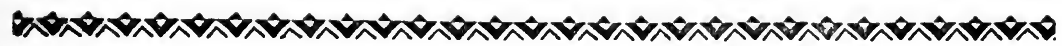

\section{STUDIES IN THE MAKING OF CITIZENS}

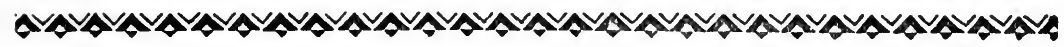


. 


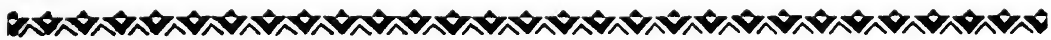

\section{CIVIC ATTITUDES IN AMERICAN SCHOOL TEXTBOOKS}

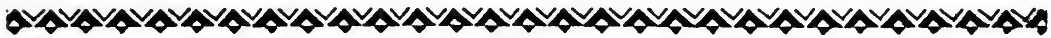


THE UNIVERSITY OF CHICAGO PRESS, CHICAGO THE BAKER \& TAYLOR CO., NEW YORK; THE CAMBRIDGE UNIVERSITY PRESS, LONDON; THE MARUZEN-KABUSHIKI-KAISHA, TOKYO, OSAKA, KYOTO, FUKUOKA, SENDAI; THE COMMERCIAL PRESS, LIMITED, SHANGHAI 


\section{CIVIC ATTITUDES}

\section{IN AMERICAN SCHOOL TEXTBOOKS}

\section{By BESSIE LOUISE PIERCE}

The University of Chicago

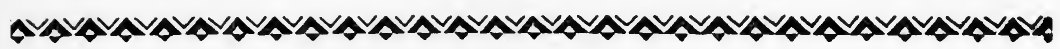

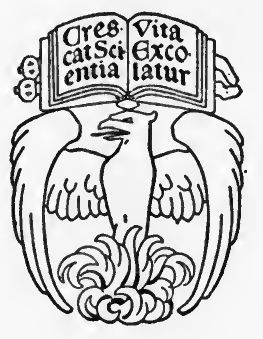

THE UNIVERSITY OF CHICAGO PRESS CHICAGO - ILLINOIS 
COPYRIGHT 1930 BY THE UNIVERSITY OF CHICAGO ALL RIGHTS RESERVED. PUBLISHED SEPTEMBER 1930

COMPOSED AND PRINTED BY THE UNIVERSITY OF CHICAGO PRFSS CHICAGO, ILLINOIS, U.S.A. 


\section{EDITOR'S PREFACE}

This study of civic education is one of a series of similar analyses in a variety of states. Broadly speaking, the common purpose of these inquiries has been that of examining objectively the systems of civic cohesion in a group of states, of determining the broad trends of civic training in these modern nations, and of indicating possibilities in the further development and control of civic education. In two of these cases, Italy and Russia, striking experiments are now being made in the organization of new types of civic loyalty. Germany, England, the United States, and France present instances of powerful modern states, and the development of types of civic cohesion. Switzerland and Austria-Hungary are employed as examples of the difficulty experienced in reconciling a central political allegiance with divergent and conflicting racial and religious elements.

The series includes volumes on the following subjects:

Soviet Russia, by Samuel N. Harper, Professor of Russian Language and Institutions in the University of Chicago.

Great Britain, by John M. Gaus, Professor of Political Science, University of Wisconsin.

Austria-Hungary, by Oscar Jászi, formerly of Budapest University, now Professor of Political Science in Oberlin College.

The United States, by Carl Brinkmann, Professor of Political Economy in the University of Heidelberg.

Italy, by Herbert W. Schneider, Professor of Philosophy in Columbia University, and Shepherd M. Clough, of Columbia University. Germany, by Dr. Paul Kosok, New York City.

Sreitzerland, by Robert C. Brooks, Professor of Political Science in Swarthmore College, Swarthmore, Pennsylvania.

France, by Carleton J. H. Hayes, Professor of History in Columbia University. (This is a part of the Columbia University series of "Studies in Post-war France" and is included here because of its intimate relation to the other volumes in the series.)

Civic Attitudes in American School Textbooks, by Bessie L. Pierce, Associate Professor of History in the University of Chicago. 
The Duk-Duks, by Elizabeth Weber, Instructor of Political Science, Hunter College, New York City.

Comparative Civic Education, by Charles E. Merriam, Professor of Political Science in the University of Chicago.

Wide latitude has been given and taken by the individual collaborators in this study, with the understanding, however, (1) that as a minimum there would be included in each volume an examination of the social bases of political cohesion and (2) that the various mechanisms of civic education would be adequately discussed. There is inevitably a wide variation in point of view, method of approach, and in execution of the project. Investigators differ widely in aptitude, experience, and environment.

Of the various investigators the question may be asked: What part do the social groupings play in the spirit of the state? What is the attitude of the economic groups which for this purpose may be considered under certain large heads, as the attitude of the business element, of the agricultural group, or of labor? What is the relation of the racial groups toward the political group whose solidarity is in question? Do they tend to integrate or disintegrate the state? What is the position of the religious factors in the given society, the Catholic, the Protestant, the Jewish? How are they concerned in loyalty toward the political unit? What is the place of the regional groupings in the political unit? Do they develop special tendencies alone or in company with other types of groupings already mentioned? What is the relation of these competing loyalties to each other?

It cannot be assumed that any of these groups have a special attraction or aversion toward government in general; and the analysis is not conducted with any view of establishing a uniformity of interest or attachment in any type of group, but rather of indicating the social composition of the existing political units and authorities. It may well be questioned whether there is any abstract loyalty, political or otherwise. These political loyalties are determined by concrete interests, modified by survivals that no longer fit the case and by aspirations not yet realized. The cohesion is a resultant of conflicting forces, or a balance of existing counterweights, a factor of the situation. 
All these factors may change and the balance may be the same, or one may change slightly and the whole balance may be overthrown. It is the integration of interests that counts, not the special form or character of any one of them.

Among the mechanisms of civic education which it is hoped to analyze are the schools, the rôle of governmental services and officials, the place of the political parties, and the function of special patriotic organizations; or, from another point of view, the use of traditions in building up civic cohesion, the place of political symbolism, the relation of language, literature, and the press to civic education, the position occupied by locality in the construction of a political loyalty; and, finally, it is hoped that an effective analysis may be made of competing group loyalties rivaling the state either within or without.

In these groups there is much overlapping. It would be possible to apply any one or all of the last-named categories to any or all of the first. Thus the formal school system made and does utilize language and literature, or symbolism, or love of locality, or make use of important traditions. Symbolism and traditions may and do overlap-in fact, must if they are to serve their purpose; while love of locality and language may be and are interwoven most intimately.

Intricate and difficult of comprehension as some of these patterns are, they lie at the basis of power; and control systems, however crude, must constantly be employed and invented to deal with these situations. The device may be as simple as an ancient symbol or as complicated as a formal system of school training, but in one form or other these mechanisms of cohesion are constantly maintained.

In the various states examined, these devices will be traced and compared. The result will by no means attain the dignity of exact measurement but will supply a rough tracing of outlines of types and patterns in different cities. It is hoped, however, that these outlines will be sufficiently clear to set forth some of the main situations arising in the process of political control and to raise important questions regarding the further development of civic education. 
It may be suggested that the process by which political cohesion is produced must always be considered with reference to other loyalties toward other groups in the same society. Many of the devices here described are common to a number of competing groups and can be more clearly seen in their relation to each other, working in co-operation or competition, as the situation may be. The attitude of the ecclesiastical group or the economic group, or the racial or cultural group, or any of them, profoundly influences the nature and effect of the state's attempt to solidify political loyalty; and the picture is complete only when all the concurrent or relevant factors are envisaged.

These devices are not always consciously employed although they are spoken of here as if they were. It often happens that these instrumentalities are used without the conscious plan of anyone in authority. In this sense it might be better to say that these techniques are found rather than willed. At any rate, they exist and are operating.

These eight or nine techniques are only rough schedules or classifications of broad types of cohesive influences. They are not presented as accurate analyses of the psychology of learning or teaching the cohesive process of political adherence. They presuppose analysis of objectives which has not been made, and they presuppose an orderly study of the means of applying objectives; and this also has not been worked out in any of the states under consideration.

This study of Civic Attitudes in American School Textbooks is based upon Dr. Pierce's examination of about 400 texts in common use. These volumes have been carefully analyzed with a view to ascertaining significant attitudes toward important phases of civic life in America. In view of the large place held by schools and textbooks in the civic education of modern states, this inquiry should prove useful in revealing some of the actualities and some of the possibilities in the special phase of the process of political education. Dr. Pierce's study will be followed by a full discussion of the Civic Education in the United States now in preparation by Professor Carl Brinkman, of Heidelberg University, Heidelberg, Germany.

Charles E. Merriam 


\section{AUTHOR'S PREFACE}

In American educational practice of the present, the two chief agencies of instruction in subject matter are the teacher and the textbook. To call attention to the importance of the latter is both needless and commonplace, and to decry its influence in the hands of a good teacher is beside the point, for in many cases it falls into the hands of a poorly prepared teacher and therefore must have considerable weight in fashioning patterns of thought in the child.

This study deals with the content of textbooks in history, civics or citizenship, sociology, and economics sometimes called "problems of democracy," geography, reading, music, and foreign language commonly found in the elementary grades and in the junior and senior high school, selected from lists of state adoptions of prescribed, recommended, and approved books, as well as those chosen by administrators of city systems. Although it does not contain all textbooks which form the basis of instruction in these fields, it is a safe assertion that it has included those most frequently found in the schools. Superintendents of public instruction in all states and many superintendents of city systems were asked to submit the list of books used in the schools under their direction. The extent to which each book was used is not known. The study includes 97 histories, 67 books in civic, sociological, and economic problems, 45 geographies, 109 readers, 10 French books, 4 textbooks in Italian, 7 in Spanish, and 50 music-books. Besides these, sixty-three courses of study, or syllabi, published by state departments of public instruction and typical city systems were read. The French books were chosen from Van Horne's list of the most commonly used books in this subject for high schools. In addition to the books appearing in the lists mentioned, some published since these lists were issued were also scrutinized, since later they may be included among the books approved for use. 
All books were surveyed to discover the civic attitudes which might be gained by a pupil who read them. It was the purpose of the study to ascertain what reactions might be engendered toward peoples, policies, and customs of other lands, to gather what other peoples think of the United States, and to find out what attitudes might be developed in the American boy or girl reading these books. The characteristics and achievements of the American, his relationship to his fellow-man, and his duty toward his country were considered. In other words, from a study of textbooks frequently found in the schools, what opinions can American boys and girls of the present form concerning their own country and of other countries? What makes up the warp and woof of their reactions to civic situations? As touching upon the problem in general, the influence of the lawmaking bodies of our commonwealths in determining the character of the curriculum has also been treated.

Possibly the conclusions reached in the following chapters might be slightly different from those set down if another investigator had performed the same task, but in the main they undoubtedly would be the same. To advocate what should be the content of textbooks does not fall within the confines of this study, for it is designed to be purely pathological and objective. For this reason quotations often chosen as representative of the thought in other books, as well as of the textbook from which they are extracted, appear frequently.

Aside from the study of Charles Altschul in 1917 dealing with the American Revolution in school histories and the work of Donald A. Taft in comparing textbooks of different countries touching the same event, little has been done in the United States to determine the character of civic instruction as derived from textbooks. In Europe, several studies have been made in a similar vein, although not identical in character. Among the best known are Prudhommeaus' Enquête sur les livres scolaires d'aprèsguerre, published in 1925 by the Dotation Carnegie pour la Paix Internationale; the Report on Nationalism in History Textbooks, prepared and compiled by the Working Committee of a Special Commission on Education (Stockholm); Jonathan F. Scott's 
analysis of textbooks published over the title of The Menace of Nationalism in Education; Carlton J. H. Hayes's study in his France: A Nation of Patriots; and Mark Starr's Lies and Hate in Education.

In the preparation of this volume I am indebted to many publishers of textbooks for their generosity in providing copies of their publications. To them I would here express my appreciation. My personal thanks are also due to Professor Charles E. Merriam, of the University of Chicago, for his suggestions and direction.

B. L. P. 



\section{TABLE OF CONTENTS}

\section{PART I. TEXTBOOKS IN HISTORY}

CHAPTER

I. Spain and the United States in History Textbooks

II. England and America

III. France in United States History Textbooks 48

IV. Germany in American History Textbooks . . . 55

V. The Relation of the United States to Countries of the Western Hemisphere . . . . . . . 68

VI. Russia in United States History Textbooks $\quad \therefore \quad 77$

VII. Countries of the Far East in American Histories 80

VIII. Racial Elements in the United States . . . 84

IX. The Dependencies of the United States . . . 93

X. The Foreign Policy of the United States . . 100

XI. Political Concepts . . . . . . . . . 102

XII. The American: His Achievements, Ideals, and Country . . . . . . . . . . . . . 106

XIII. International Attitudes in Some European History TextвoOKs . . . . . . . . . . . . . 131

PART II. TEXTBOOKS IN CIVICS, IN SOCIOLOGY, IN ECONOMIC AND POLITICAL PROBLEMS

XIV. The American Citizen: His Rights and Duties . 139

XV. The American and Other Peoples . . . . . 151

XVI. The Achievements of America . . . . . . 167

PART III. TEXTBOOKS IN GEOGRAPHY

XVII. The United States and Peoples of Other CounTRIES . . . . . . . . . . . . . . 175

XVIII. The Achievements of the United States . . 188 


\section{PART IV. READERS}

CHAPTER PAGE XIX. The United States and Other Nations . . . . 193 XX. The American and His Country . . . . . . 207 PART V. TEXTBOOKS IN MUSIC AND FOREIGN LANGUAGE

XXI. Music . . . . . . . . . . . . . . 217 XXII. Foreign Language . . . . . . . . . . 222

PART VI. OFFICIAL POLICIES

XXIII. Laws Affecting Civic Instruction . . . . . 229 XXIV. Courses of Study $\quad . \quad$. . . . . . . . . . . 242 Conclusion . . . . . . . . . . . . . . . 253 List of Books ANALYzed . . . . . . . . . . . 257 INDEX . . . . . . . . . . . . . . . . . 285 
PART I

TEXTBOOKS IN HISTORY 



\section{CHAPTER I}

\section{SPAIN AND THE UNITED STATES IN HISTORY TEXTBOOKS}

The year 1492 marks the beginning of contacts of the pupil of American history with world-events and peoples. His study of the period of the exploration of America introduces him to daring, "harsh," and "cruel" Spanish adventurers searching for gold in the New World, men of avarice and mere soldiers of fortune. " They were "men of primitive character," asserts The Story of Our American People. "That is to say they acted with little thought. Their emotions were unusually selfish and knew small guidance or control. Their hates were fierce and brutal. Their trust in romance was extravagant. Their desires were for obvious things, riches, power, fame."2 In their relations with the natives, the Spaniards are described as especially harsh and cruel, although contributing to the Indians "many useful lessons."

An opposite point of view is expressed by a history for Catholic schools, which declares: "To Spain is due the discovery of the New World; she it was who opened it up to civilization. Her teachers taught the Spanish language and Christian faith to thousands of aborigines." Her "policy toward the Indians was

${ }^{1}$ Channing, A Students' History of the United States, p. 30; Forman, Advanced American History, p. 13; McLaughlin, History of the American Nation, p. 15. These are typical examples. Most histories paint the Spanish in this way.

${ }^{2}$ Charles Horne, The Story of Our American People, I, 44. The history indorsed by the American Legion designed for seventh or eighth grade. This is taken from the "advance" edition. It should be said, however, that this textbook is probably not widely used at the present. Muzzey, in his An American History, mentions their spirit of romance as well as missionary zeal (p. 13). See also his History of the American People, p. 25. Muzzey's textbook has wide use.

${ }^{3}$ Burnham, The Making of Our Country, p. 13. This is a textbook for junior high school. 
one of humanity, justice, education and moral suasion," although "individual Spaniards broke the strict law of their country and treated the Indians with the utmost cruelty."4

Few authors find much in the Spaniard to commend. Channing and Burnham mention their "energy" and the "hardships" encountered in the daring exploit of exploring a new world. Yet their colonial system is described as entirely lacking religious and political freedom. ${ }^{5}$

Undoubtedly the incident which will most permanently impress itself upon the pupil is that of the cruelty of Menendez to Ribaut, whose "settlement was a double defiance both of their country and of their religion." In colorful language are chronicled Menendez' approach to Florida and the scattering of the French fleet by a hurricane, welcomed by the Spaniards as "the direct protection of Providence."

Horne writes in The Story of Our American People,

While the great storm still raged, Menendez and a company of his soldiers struggled secretly northward against its fury, and suddenly in the midst of the tempest attacked the French settlement. . . . . Every male prisoner was hanged, and the bodies were left with a notice beside them that they had been slain "not as Frenchmen but as heretics." Then Menendez returned in triumph to St. Augustine; and when the wretched survivors of Ribaut's wrecked fleet were found there upon the beach, they also were slain. Only at the last did the stern Spaniard's fierceness fail him. He spared some few of the last men along with the women and children.... The Spanish king promptly approved Menendez' slaughter of the captured "heretics," criticized him only for sparing the survivors and condemned these to become "galley slaves." 6

Although not couched in such stirring language as the passage quoted, other histories at present in use in the schools discuss the attack of Menendez, who is generally described as cruel and

- The Franciscan Sisters of the Perpetual Adoration, $A$ History of the United States for Catholic Schools, pp. 42-43. Muzzey, An American History, notes the missionary spirit of the early Spanish. See p. 13. Thus it is seen that it is mentioned also by others than Catholic authors.

- Channing, op. cit.; Burnham, op. cit., p. 14.

- Horne, op cit., pp. 83-84. 
merciless ${ }^{7}$ and who "butchered in cold blood" the Huguenot settlement. ${ }^{8}$

Children reading the History of the United States for Catholic Schools by Charles H. McCarthy will get a different impression of the Menendez-Ribaut episode. In a footnote to the general discussion in which none of the details appear lurid, Dr. McCarthy says :

This affair, bad enough in any view, is misrepresented in some books, where it is said that the French, who were nearly all Protestants, were massacred by the Spaniards on account of their religion. There is no doubt that the religion of the French settlers added to the anger of the Spaniards, but it must also be remembered that the Spaniards first knew their neighbors as pirates. The French Huguenots were just as cruel as Spanish Catholics. About ten years before, 1555, Jacques de Sorie captured the castle at Havana and though he promised quarter to its garrison, put all his prisoners to the sword. He then burned churches and mutilated images. ${ }^{9}$

The later exploits of the Spanish are described in equally uncomplimentary terms in textbooks found particularly in Protestant schools. Neither the policy of Spain in Louisiana as it affected the West ${ }^{10}$ nor Spanish colonial policy is discussed in a manner which will tend to change the attitude already gained by the pupil. Thompson, in his History of the People of the United States, for example, says: "The Spanish colonies in America were long suffering. The colonial policy of Great Britain, on account of which the United States fought and won its independence, was generous in comparison with the colonial policy of Spain." Evans, in The Essential Facts in American History, mentions the "iron hand of tyranny and extortion" used by Spain in her American colonies, inhabited by a people whom Garner and Henson describe as "down-trodden."

' Forman, op. cit., p. 17; Guitteau, Our United States, p. 231; Thompson, $A$ History of the United States, p. 24.

${ }^{8}$ Latané, A History of the United States, pp. 13-14.

'McCarthy, The History of the United States for Catholic Schools, p. 38 .

${ }^{10}$ Burnham, op. cit., p. 222.

${ }^{11}$ Thompson, History of the People of the United States, p. 251; Evans, The Essential Facts in American History, p. 279; Garner and Henson, Our Country's History, p. 278. 
Nida points out in The Daren of American History in Europe:

The Spanish were earliest upon our shores, but they wasted their time and resources in wild searches for gold, until they lost control of the sea. They did not know the importance of honest labor, nor did they appreciate the value of thinking men in politics or religion. They made a mistake in denying liberty of thought to their people. Every prosperous nation must have workers and thinkers, but Spain had neither. The Spanish rulers and nobles claimed to have Teutonic blood in their veins, but they had lost the spirit of liberty and all other virtues of the Teutons. Since they misunderstood their own people and misgoverned their own country, it is no wonder they failed in the struggle for possession of America. ${ }^{12}$

After the passage of four centuries, the same characteristics still seem a part of Spanish rule. It was the tyranny and selfishness of Spain's colonial policy which are said to have "compelled" the American government "in the interests of humanity" to intervene, in 1898, in the revolt of Cuba. ${ }^{13}$

'Thompson declares in the History of the People of the United States:

The peoples of the United States could not be indifferent to the conditions in Cuba. The island lies but a little more than a hundred miles from Florida. So long as it was held by a foreign power, it might in time of war, become a source of danger as a base for the enemy's operations.

But over and above these considerations, the American people had a genuine sympathy for the Cubans in their struggle for liberty and an abhorrence for the Spanish mode of warfare, ${ }^{14}$

a system full of "barbarities" and "inhuman methods."15

The archtraitor in the Spanish-Cuban struggle is General Weyler, "a fiercely resolute general" known to Cubans as "the

${ }^{12}$ Nida, The Daron of American History in Europe, p. 365.

${ }^{13}$ Mace, School History of the United States, p. 448. See also Guitteau, op. cit., pp. 525, 526; Tryon and Lingley, The American People and Nation, p. 580; Barker, Webb, and Dodd, The Growth of a Nation, p. 608; Muzzey, The American People, p. 509; and others.

${ }^{14}$ Thompson, History of the People of the United States, p. 438. Also mentioned, among others, by Tryon and Lingley, and Muzzey.

${ }^{15}$ Woodburn and Moran, Elementary American History and Government, p. 413; Gordy, History of the United States, p. 423. 
butcher," 16 whose reconcentrados led Americans to send Cubans food and medical aid and to condemn such "horrible conditions" in the platforms of both great political parties in $1896 .{ }^{17}$

[Thus] after thirty years of peace [declares Daffan], the United States again engaged in war from as high a motive as can bring about war. Not to acquire new territory, not to humiliate a rival nation, not to avenge a wrong done to herself, this war was begun to put an end to human oppression and suffering. ${ }^{18}$

Substantially all of the histories used in the schools present the situation in much the same manner. ${ }^{19}$

As a contributory factor in American interest in Cuba the spur of economic contacts is discussed by a few authors. McCarthy, for instance, in his History of the United States for Catholic Schools, minimizes the humanitarian object of the United States and declares that "our country was interested in Cuba because of its situation just off our shores, and later because our people had invested their money in its mines, railroads and plantations." 20

Another writer confesses that the constant warfare between Spain and Cuba interfered greatly with our commerce with the

${ }^{16}$ Horne, op. cit., II, 350; Fite, History of the United States, p. 497.

${ }^{17}$ McMaster, A School History of the United States, pp. 473-74; Muzzey, An American History, p. 452, and IIuzzey, History of the American People, p. 506 .

${ }^{18}$ Daffan, History of the United States, p. 531.

${ }^{19}$ See, for instance, Bourne and Benton, American History, p. 544; Channing, A Students' History of the United States, pp. 549-50; Channing, Elements of United States History, pp. 327-28; Eggleston, First Book in American History, p. 186; Estill, Beginner's History of Our Country, p. 280; Fite, The United States, p. 395; Fite, History of the United States, p. 497; Forman, op. cit., p. 521; Garner and Henson, op cit., pp. 526-27; Hall, Smither, and Ousley, History of the United States, pp. 426-27; Halleck, History of Our Country, pp. 434-35; Leonard and Jacobs, The Nation's History, p. 463; Long, America, p. 453; McLaughlin, op. cit., p. 575; Mace and Bogardus, History of the United States, pp. 367-68; Thompson, First Book in United States History, pp. 357-58; West and West, The Story of Our Country, pp. 458-59; White, Beginner's History of the United States, pp. 303-4.

${ }^{20}$ McCarthy, op. cit., p. 435. See also, for similar point of view, Tryon and Lingley, op. cit., p. 579; Muzzey, History of the American People, pp. 505-6. 
islands, and that the Cuban revolt was "too much like a house on fire in the neighborhood" for Americans to ignore it. ${ }^{21}$

A consistent sympathy on the part of this country in the efforts of oppressed people to gain their freedom and independence is noted by McLaughlin and Beard. ${ }^{22}$ Channing, with others, shows how the interest of the United States in Cuba as a possession had extended over many years, and that "its command of the Caribbean Sea makes American control of it almost a military necessity."23 Such a point of view is rarely expressed in the histories of elementary school level, but appears occasionally in some of the senior high school textbooks.

The attitude which European nations took toward American intervention in Cuba is discussed particularly by books written since the World War, in which is set forth the sympathetic response of England in contrast with the reactions of other European powers.

Most of the European nations sided with Spain and thought the United States should mind her own business [says Halleck]. Continental newspapers called the war "an act of international piracy without shadow of justice." The great English papers, with one exception, took the side of the United States. When London heard of the declaration of war, the Stars and Stripes were displayed in every part of the city. Crowds of Englishmen went to the American Embassy in London and cheered. There had been talk of foreign intervention to stop the war, but when Great Britain's attitude became known, such talk ceased. ${ }^{24}$

Thus was fought by Americans the "people's war"25 against the "weak nation" Spain, ${ }^{26}$ for whom it was "folly" to try "to measure swords with the virile, unmeasured power of the United States."

${ }^{21}$ Robbins, School History of the American People, p. 462.

${ }^{22}$ McLaughlin, op. cit., p. 515; Beard, History of the United States, p. 487 .

${ }^{23}$ Channing, A Students' History of the United States, p. 548; Beard, op. cit., pp. 485-89; Hulbert, United States History, p. 485.

${ }^{24}$ Halleck, op. cit., pp. 435-36. Among others the American Legion history expresses the same sentiment.

${ }^{25}$ Horne, op. cit., II, 350.

${ }^{28}$ EIson, United States: Its Past and Present, p. 481. ${ }^{27}$ Ibid. 


\section{CHAPTER II}

\section{ENGLAND AND AMERICA}

Anglo-American relations as set forth in our school histories fall naturally into distinct periods. The first discusses the opening up of English settlements; the second deals with the Revolutionary epoch, followed by events leading to the War of 1812; the fourth is devoted to a treatment of relations between the two countries after the Treaty of Ghent through the Civil War and the Spanish-American War to 1917; and the last deals with our relations with England as her ally in the World War. Aside from the friendship of England in 1898 recorded by some historians, relations up to 1917 are discussed, on the whole, in such a way that Anglo-American concord will not be promoted.

Although Drake, Gilbert, Raleigh, and other English explorers are surrounded with a romantic atmosphere, their exploits are not narrated in a way to kindle antagonisms in the reader as in the case of Spanish adventurers. Their story merely prepares the way for the coming of English colonists to America. Jamestown may be passed by with little comment for the settlement of the Pilgrims who "had left England because they were not permitted to worship God as they wished" since "the English law was unjust."

\section{According to A School History of the United States, ${ }^{2}$}

There has seldom been a gentler and kinder group of people than the Pilgrims. They appear to have had good will toward all men, even toward the cruel king from whom they had fled and toward the savages of the forests. They valued so highly the freedom to worship God in their own way that they would not refuse the same freedom to others. Their little republic-for so we may describe

${ }^{1}$ Coe, Founders of Our Country, p. 154; Baldwin, The Story of Liberty, p. 63. The latter may be classified also as a reader.

2Stephenson, A School History of the United States, p. 50. "A Godfearing and industrious people," according to Hart, New American History, p. 46. 
their settlement-was a land of peace and good will, [which had] a large influence in shaping the character of our people. ${ }^{3}$

The Puritans, too, came to escape "persecution on account of religion." At the time Winthrop and his followers came to America, Puritans are said to have been "suffering imprisonment, and having their ears cropped and their noses slit on account of their religious opinions."4 According to historians, political tyranny as well as religious persecution played a part in the Puritan exodus. ${ }^{5}$ There is practically no mention of an economic motive.

Following the settlement of the colonies, textbook writers, on the whole, embark chiefly upon a discussion of such factors in colonial life as social and economic development and forms of local government. Even the Andros episode provokes slight unpleasantness, although described by one author as making "a short end of the liberty which the Puritans had built up by labor and sacrifice."

In the struggles between France and England during the eighteenth century, the participation of the colonists in America is applauded. Regardless, however, of the aid given, the pupil is told that in $\mathbf{1 7 4 8}$

France and Britain traded with one another for fragments of the widespread empire of each. Britain gave back Louisburg in exchange for advantages in other lands. This careless neglect of America's interests, this indifference to her great triumph, was a cruel blow to all our people, especially the New Englanders. It taught them how little they could trust to Britain's protection. ${ }^{\text {? }}$

${ }^{3}$ Fish, History of America, p. 22.

- Forman, Advanced American History, p. 39. See also Thompson, A History of the People of the United States, p. 37.

'Fite, History of the United States, p. 40; Halleck, History of Our Country, p. 79; Forman, op. cit., p. 39; McMaster, A School History of the United States, p. 47; Mace and Bogardus, History of the United States, p. 42; O'Hara, A History of the United States, p. 72; West, The Story of Our Country, p. 77.

${ }^{6}$ Long, America, pp. 123-24.

'Horne, The Story of Our American People, I, 299, Long's treatment of the episode is much the same. See Long, op. cit., pp. 134-35. 
Indeed, the return of Louisburg to France is said to have caused the colonists "chagrin" because they had lost "their hardearned prize," and, according to the authors of a history for Catholic schools, "was one of the first events which led the English colonies to see that American affairs should be settled on this side of the Atlantic and not by a power thousands of miles away.".9

Others mention the return of Louisburg to France in a manner to create the impression that the colonists were treated unjustly. ${ }^{10}$ Hulbert, in his discussion of the American phases of the European wars, goes so far as to say that the capture of posts by the colonists was of "so little consequence" to the "Mother Bear (England)" that when "truces were made with France, the gains in America were usually sacrificed. Thus the colonists had the cold truth thrust home upon them that if they stood between the Mother Country and her imperial ambitions they would be brushed aside."11

The classic example of the "blundering tragedies" of England is Braddock's defeat in the French and Indian War, "typical of several others that stunned or enraged our colonies, and that must have disheartened any people less resolute to make an end of the French menace to liberty."12 For this "disaster" Braddock, "obstinate and arrogant, with a noisy contempt for every-

${ }^{8}$ Garner and Henson, Our Country's History, p. 99. See also Burnham, The Making of Our Country, p. 98.

${ }^{\circ}$ The Franciscan Sisters of the Perpetual Adoration, A History of the United States for Catholic Schools, p. 137.

${ }^{10}$ Channing, Elements of United States History, p. 95; Evans, The Essential Facts of American History, p. 138; Lawler, Essentials of American History, p. 134; McLaughlin and Van Tyne, A History of the United States for Schools, p. 115; McMaster, op. cit., p. 81; Mace, School History of the United States, p. 124; Muzzey, An American History, p. 80; Robbins, School History of the American People, p. 90.

${ }^{11}$ Hulbert, United States History, p. 103. The "disappointment" of the colonists is mentioned by some writers such as O'Hara, Thompson, Thwaites and Kendall, and Mace and Bogardus: O'Hara, op. cit., p. 109; Mace and Bogardus, op. cit., p. 100; Thompson, op. cit., p. 90; Thwaites and Kendall, A History of the United States, p. 124.

${ }^{12}$ Long, op. cit., p. 138. 
thing colonial," some hold accountable. ${ }^{13}$ Even those authors who attribute bravery to Braddock, in some cases qualify their statements by describing him as "haughty and self-willed"14 and "a bigot to military rules." 15

On the other hand, Channing, for instance, does not indulge in adjectives uncomplimentary to Braddock, but describes the defeat as follows:

It happened, therefore, when Braddock and his men had crossed the last river, and had gained a point within a few miles of Fort Duquesne, that they suddenly found themselves assailed in front and on either side by Indians and white men, fighting wilderness fashion from behind trecs and anything else that offered protection. This was a kind of warfare to which Braddock and his English troops were entirely unaccustomed. They were brave and so was he, but he could think of no better way to meet this danger than to arrange his men in line and advance to the attack exactly as if he had been fighting regular French soldiers on an open battlefield of Europe. Washington and the Virginians did what they could to save the day by fighting the Indians and French in their own manner, but this proved to be impossible. Braddock was mortally wounded, retreat was ordered, and the defeated soldiers ran away, each man for himself as fast as he could go. ${ }^{16}$

Any protection given the colonists by England in the intercolonial struggles is mentioned rarely. Forman, however, in his treatment of the French and Indian War, points out that "it was England and not the colonies that offered determined and successful resistance to France."17

Doubtless the narration of the Franco-English struggles as

${ }^{13}$ Horne, op. cit., I, 306. See also Barnes, American History for Grammar Grades, p. 169; Burnham, op. cit., pp. 101-2.

${ }^{14}$ Elson, United States: Its Past and Present, p. 108. See also Garner and Henson, op. cit., p. 105; Evans, op. cit., p. 141.

${ }^{15}$ Guitteau, Our United States, p. 117. See also Gordy, History, of the United States, p. 94; Woodburn and Moran, Elementary American History and Government, p. 97.

${ }^{16}$ Channing, op. cit., p. 99. See also Estill, The Beginner's History of Our Country, pp. 149-50; Bourne and Benton, History of the United States, p. 128; Forman, op. cit., p. 95.

${ }^{17}$ Forman, op. cit., p. 64. 
carried on in America, in themselves, would kindle little antagonism to England if they were the only instances of hostility toward the mother-country. But others follow. And these lead directly to the Revolutionary War, the episode in which the greatest animosity toward any country is evinced, with the possible exception of some discussions of Germany in the World War.

To the pupil reading Elson's United States: Its Past and Present it is pointed out that, following the French and Indian War,

there were some forces working in the direction of separation. Some of the American people were not English-the Dutch, Irish, Germans, and others - and these did not inherit a filial love of the motherland; and the great majority of English descent had been born on this side of the water and had never seen England. Furthermore, the colonists had long chafed under the irritating Navigation Laws and the transportation to the colonies of many criminals from the British prisons. These things did not show the fond affection of a parent for a child; but they were not enough to bring about a separation. That was brought about by a series of official blunders covering a dozen years. ${ }^{18}$

In this fashion the child is prepared for the approach of the American Revolution, the result of "the unjust treatment of England" upon colonists who "loved old England, the land of their fathers, and were proud of their kinship with her." The reader is shown how the mother-country, contributing to colonial unrest, "often appointed worthless men ... . who despised the people they ruled," and how there were enacted "English laws" which were "aimed to make English merchants and traders richer, but which, at the same time, kept the Americans poor."19

Even West and Muzzey, recently attacked as "unpatriotic" and "pro-English" by organizations such as the Sons of the American Revolution and by Commissioner of Accounts Hirshfield, in his report on history textbooks used in the New York

${ }^{18}$ Elson, op. cit., pp. 119-20.

${ }^{10}$ Estill, op. cit., pp. 155-56. See also Latané, History of the United States, pp. 92-93; Evans, op. cit., pp. 176-77; Barnes, Short American History, p. 6 . 
City schools, ${ }^{20}$ do not give England a clean bill of health in her mercantile policy. Muzzey points out that "the colonies were naturally aggrieved at such treatment," characterizing the laws as "ugly" and "odious."21

By West, the English laws of 1696, 1732, and 1750 are described as "selfish and sinister."

They must have become bitterly oppressive ere long, had the colonists continued under English rule; and at the time they fully deserved the condemnation visited upon them by the great English economist, Adam Smith: "These prohibitions are only impertinent badges of slavery, imposed upon [the colonies] without sufficient reason by the groundless jealousy of the manufactures of the mother country." 22

The Sugar Act of 1733, according to Professor West, was "another source of justifiable irritation."23

Evasion of the laws of England by the colonists is frequently mentioned, although in such a way that colonial honor is not impugned.

Had the Molasses Act been strictly enforced, the prosperity of New England would have been at an end. But smuggling was carried on so generally that the revenue laws were practically nullified; the customs officers and even the royal governors connived at the practice.... The strict enforcement of these acts threatened the commercial prosperity of the colonies; and thus the real issue between them and Great Britain became one of home rule-whether the colonies were to be allowed to map out their own destinies, or whether they were to be held in permanent tutelage to the British government. ${ }^{24}$

Gordy declares in his History of the United States:

The Sugar Act would greatly injure New England trade with the West Indies, and this trade was one of the principal sources of ${ }^{20}$ See Bessie Louise Pierce, Public Opinion and the Teaching of History in the United States (New York, 1926), pp. 221-22, 253-58, 283 ff.

${ }^{21}$ Muzzey, op. cit., pp. 92, 93.

${ }^{22}$ West, History of the American People, pp. 148-49. The italics are in the textbook.

${ }^{23}$ Ibid., p. 149. See also Gordy, op. cit., pp. 122-23. These are typical.

${ }^{24}$ Guitteau, The History of the United States, p. 113. 
wealth to New England merchants. Threatened with financial ruin, they had to choose between that and smuggling. Believing the law was an unjust interference with their mutual rights, they chose smuggling, and for a time England allowed it to pass unnoticed. ${ }^{25}$ [On the whole, however] colonists proved themselves a law-abiding folk until Parliament, seeking more money to meet growing expenses, decided to revive the old navigation acts. Even then it was not so much the acts .... as the outrageous method of enforcing them which bred a spirit of rebellion. ${ }^{26}$

Instances might be multiplied to show that, although smugglers, the colonists were criminal only in the literal interpretation of the law. In general, the pupil would not condemn, but would probably uphold the colonists in an evasion of a law painted as unjust and unwise. ${ }^{27}$

Some authors point out that the Navigation laws and Acts of Trade were not entirely harmful to colonial industry. McLaughlin, Guitteau, Beard and Bagley, Bourne and Benton, Channing, Fite, James and Sanford, West, and others not only indicate causes for colonial resentment, but also show that "the enumerated commodities, which could be shipped only to Great Britain, were given a preference in that market over similar commodities from other countries." 28 Few authors speak so frankly as Garner and Henson:

It was not, however, until the French and Indian War that the ministry seemed to realize the seriousness of colonial smuggling. So disloyal, at that time, were many of the New Englanders, that although the mother country and the colonists themselves were en-

${ }^{25}$ Gordy, op. cit., p. 123.

${ }^{26}$ Long, op. cit., p. 157.

${ }^{27}$ See West, The 'Story of Our Country, p. 134; Halleck, op. cit., p. 167; Burnham, op. cit., pp. 58-59; Evans, op. cit., p. 177; Horne, op. cit., I, 282; Fish, op. cit., pp. 120-21; Muzzey, op. cit., p. 91 ; Fite, op. cit., p. 98.

${ }^{28}$ McLaughlin, History of the American Nation, p. 137; Guitteau, The History of the United States, p. 113; Guitteau, Our United States, p. 130; Beard and Bagley, The History of the American People, p. 127; Bourne and Benton, op. cit., p. 118; Channing, A Students' History of the United States, p. 112; James and Sanford, American History, p. 142; West, History of the American People, p. 185. Quotation from Fite, op. cit., p. 99. 
gaged in a life and death struggle with the French in America, they persisted in smuggling supplies to New France. ${ }^{29}$

Discussions concerning the Proclamation Line of 1763, the Writs of Assistance, the insistence of James Otis upon the political belief that "a man's house is his castle," the Stamp Act, and succeeding events present the facts from a colonial point of view, although endeavoring in many instances to set forth the British side. A comparison of textbooks now in use with those of a generation ago reveals in the books of the present an attempt to present two sides of the story. Although British colonial policy is said to have been an "unwise course" to which the colonists "naturally"30 objected, it is generally made clear that, on the whole, British colonial government was better than that of other countries of the time. ${ }^{31}$ Yet few writers leave doubts as to the folly of the colonial policy adopted, although they may present reasons for it. As in Long's America, the tendency is to show that the mother-country's policy was unjust, selfish, and ill-advised.

England's political mistake was to regard colonies as dependencies; her economic mistake was to regard them as a mere source of profit to herself. The mercantile theory, then held by all nations, alleged that colonies must make money for Englishmen or Spaniards who stayed at home and invested their funds in ships or goods for colonial trade.

American colonists had a different idea. Following a vision of liberty, they came here not to benefit English commerce but to better themselves. They came first in Elizabethan days, with the Elizabethan spirit of adventure, of pride of race and nation; and they kept their pride while England submitted to the tricky despotism of Charles II

${ }^{29}$ Garner and Henson, op. cit., p. 140.

${ }^{30}$ Thompson, First Book in United States History, pp. 188-89. See also Barnes, American History for Grammer Grades, p. 183; Lawler, op. cit., p. 170; Fish, op. cit., p. 132; Horne, The Story of Our American People, I, 323; Long, op. cit., p. 157; Elson, op. cit., p. 121.

${ }^{31}$ See, for example, Franciscan Sisters of the Perpetual Adoration, A History of the United States, p. 168; Hulbert, op. cit., p. 121; Bourne and Benton, op. cit., p. 118; Thompson, A History of the People of the United States, p. 108; Beard, History of the United States, p. 69; Muzzey, op. cit., p. 57; West, History of the American People, p. 115. 
or the stupid despotism of George III. They had more of the old free English spirit than could be found in England itself. They represented the empire, and were loyal to it; but with all their hearts they loved this land, its wideness, its beauty, its promise that here would Liberty dwell with their children forever; and it became holy in their eyes when they laid their dead to rest beneath its soil. To them America meant all that is expressed in the two dearest words in our language, "home" and "country." England thought of America as "the colonies," places to hunt for furs or grow tobacco for the benefit of British commerce, and made laws to that effect.

In many of the textbooks in most common use a clear distinction is drawn between the political theories of the colonists regarding representation and those held in England. These writers obviously endeavor to point out that a cause for misunderstanding sprang out of two different schools of political thought as to representative government.

The phrase "no taxation without representation" was familiar to all sections of the British people, but it conveyed very different ideas to those living in Great Britain and to their kinsfolk in the colonies. The British Parliament was composed of two houses,-the Peers, comprising hereditary nobles and the bishops, and the House of Commons. The members of the latter body were elected, and were supposed to represent all classes of people. Some of the electoral districts, indeed, contained no inhabitants. In one of these, Old Sarum, it was possible in dry seasons to trace the foundations of old buildings by the color of the grass, in another, Midhurst, the sites of' old allotments were marked by stone posts-while one borough "had sunk beneath the waters of the North Sea." Yet each of these returned members to the House of Commons.

In the colonies, representation was everywhere apportioned on a territorial basis, which was being constantly changed to suit the altered conditions of the several parts of each colony..... This right was regarded as a most valuable one in the colonies. . . . .

In the matter of the franchise there was an equally wide difference of opinion. In Great Britain, it depended for most part, upon the possession of some peculiar privilege. In the colonies, the franchise was regulated by general rules and was usually given to all free adult white men who possessed a moderate amount of property. . . . . In Great Britain, there was no requirement of residence for the rep- 
resentative or the voter. In the colonies, residence was ordinarily required for both the voter and representative.... To the colonist, therefore, the phrase "no taxation without representation" meant that no tax could be; levied except by vote of a legislative body in which a person known to the voter, and in whose election he had taken part, had a seat; but to an Englishman the phrase meant simply "no taxation except by vote of the House of Commons" (Channing, A Students' History of the United States, pp. 118-19).

In England multitudes of tax-payers could not vote. If a town centuries before had not been big enough to send members to Parliament, it could not now send members, however big it was. At the same time towns which once had received the right to send members and had grown small did not lose the right. If now the same lord owned all the property in a town or in three or four of them, he chose the members. Scores of members were in reality named by great lords or by the king. The colonists would not have endured a legislature like that. Their objection, however, was that parliament did not represent them in the sense in which they understood representation (Bourne and Benton, History of the United States, p. 138).

We, in this country, do not consider a person represented in a legislature unless he can cast a vote for a member of that legislature. In Great Britain, not individuals but classes were represented.... At that time, very few Englishmen could vote for a member of the House of Commons. Great cities like Liverpool, Leeds, Manchester, did not send even one member. When the colonists held that they were not represented in Parliament because they did not elect any members of that body, Englishmen answered that they were represented, because they were commoners (McMaster, A School History of the United States, pp. 115-16).

Many other examples might be cited, but the sentiment differs in no great degree. It is sufficient to indicate that the pupil reading such discussions would plainly observe a difference in the theories as to representation held in England and in America. Doubtless he will again conclude that the Americans were right and the English were wrong, but he will see at least that the English were not imposing burdens upon the colonists not borne by themselves, that they were accepting the same obligations to government and bearing them in the same manner as they de- 
manded from the colonial empire. ${ }^{32}$ On the other hand, only about one-half of the most frequently used textbooks make so clear the distinctions regarding the theory of representation and the taxing power as have the preceding. For example, Estill, in The Beginner's History of Our Country, merely says :

The Americans did not mind paying a tax which they themselves had decided was right. But no Americans were allowed to be members of the English Parliament, by which the stamp law and all other stamp laws of England were passed. To the colonists this taxing them without their consent-without their being represented in Parliament was more than the Americans could stand. From one end of the colonies to the other the people repeated the words of an American speaker, "Taxation without representation is tyranny." They decided they would never pay the tax. ${ }^{33}$

Horne's The Story of Our American People, written under the auspices of the American Legion, moreover, in explaining why the colonies and England drifted apart, ascribes the separation to the failure of the upper classes of England to sympathize with us. ". . . . They regarded the Americans as an ignorant frontier folk, incapable of orderly self-government or persistent

${ }^{32}$ See also Burnham, op. cit., pp. 110-11; Fish, op. cit., pp. 135-36; Gordy, op. cit., p. 130; Guitteau, Our United States, pp. 145-46; Guitteau, The History of the United States, pp. 111-12; Fite, op. cit., p. 110; Franciscan Sisters of the Perpetual Adoration, A History of the United States, p. 171; James and Sanford, op. cit., p. 147; Hulbert, op. cit., p. 120; Thwaites and Kendall, op. cit., pp. 144-45; Forman, op. cit., p. 113; Muzzey, op. cit., pp. 97-98; McLaughlin, op. cit., pp. 133-34; McLaughlin and Van Tyne, op. cit., pp. 144-45; O'Hara, op. cit., pp. 126-27; Evans, op. cit., p. 179; Thompson, History of the People of the United States, p. 115; Beard, op. cit., p. 79; West, History of the American People, pp. 187-88; Bourne and Benton, American History, p. 77; Barker, Webb, and Dodd, The Growth of a Nation, pp. $148-49$.

${ }^{33}$ Estill, op. cit., p. 156. See also Barnes, American History for Grammar Grades, p. 183; Beard and Bagley, op. cit., pp. 130-31; Fite, The United States, p. 136; Lawler, op. cit., pp. 172-73; Leonard and Jacobs, The Nation's History, pp. 148-49; McCarthy, History of the United States, pp. 150 ff.; Mace, op. cit., p. 141; Mace and Bogardus, op. cit., p. 112; Hart, School History of the United States, p. 123; Hart, New American History, p. 129; Elson, op. cit., p. 123; Robbins, op. cit., p. 112; Stephenson, op. cit., p. 153; West, The Story of Our Country, p. 151; Woodburn and Moran, op. cit., p. 125. 
warfare," we are told. "Not even our successful Revolution could quite shake Britons out of this stubborn sureness of their superiority. ...."

Britons have often since excused the course their Parliament then took against America by pointing out how well meant were some of the laws which most offended us. This avoids the real dispute, which was about Britain's right to make laws for us at all.... No authority which extends a law over a body of outsiders. who object to it, can then demand or hope that the outsiders will be obedient when the law injures them, or grateful when it chances to turn in their favor.

Americans had governed themselves from the beginning. They were now a grown-up people; and no power on earth could take selfgovernment from them..... In this new land the mass of mankind had at last reached a level where they had enough intelligence to recognize and follow honest leaders, and had enough boldness and endurance to continue steadfast in defeat.... This question of selfrule was the real basis of all our trouble with Britain. ${ }^{34}$

The person held most accountable for the separation of the colonies from England is George III, described as "obstinate," "narrow-minded," "bigoted," "stubborn," "selfish," and "insane." Charged with the use of bribery to surround himself with ministers and others who would carry out his will, he is conceded by few authors to have had any goodness hidden in his nature. He stands convicted as a foe to liberty, a believer in absolutism. And not the least of his faults was his German birth. ${ }^{35}$

A few authors, although criticizing his colonial policy, do not picture King George as the sum of all iniquities. West, in The History of the American People, describes him thus:

"In his private life he exactly fulfilled the popular ideal of a good ruler. In an age when society was recklessly dissolute, he was chaste

34 Horne, The Story of Our American People, I, 320-21. In regard to the Quartering Act this author also remarks: "The Americans, however, had already endured the insolence of British soldiers and British generals, and wanted no more of it" (ibid., p. 325).

${ }^{35}$ Thwaites and Kendall, op. cit., pp. 140-41; Leonard and Jacobs, op. cit., p. 163; Guitteau, Our United States, p. 146; Daffan, History of the United States, p. 179; Muzzey, op. cit., pp. 107-8; Horne, The Story of Our American People, I, 318. King George is unfavorably criticized in most of the books reviewed. 
in conduct, temperate in diet, and simple in manners. While irreligion abounded, he kept a virtuous home, whose days, beginning with family prayer, were passed in laborious performance of duty." King George was exceedingly conscientious, but exceedingly wrong-headed and narrow-minded. He was a good man but a bad king. ${ }^{36}$

\section{Hart, in his School History of the United States, says:}

In one of his (George III's) early speeches he said, "Born and educated in this country, I glory in the name of Briton." He was in many ways a good man, upright, truthful, and true to his friends; but he was a poor king, for he was narrow, stubborn, and determined to be stronger than Parliament. ${ }^{37}$

The program of the king as it related to the American colonies was not unanimously indorsed by Englishmen, according to Barnes, Beard and Bagley, Bourne and Benton, Burnham, Elson, Evans, Fish, Fite, and others. ${ }^{38}$ Out of forty histories most commonly used in the schools, only three fail to mention opposition in England to the king's policy, a far better proportion than Altschul found. ${ }^{39}$ Taking this as a basis for a sweeping statement, which may be somewhat inaccurate, there are not over

${ }^{26}$ West, History of the American People, p. 191, footnote. West quotes from Ford's American Politics, p. 344.

${ }^{37}$ Hart, School History of the United States, p. 122.

${ }^{28}$ Barnes, American History for Grammar Grades, p. 187; Beard and Bagley, op. cit., pp. 137-39; Beard, op cit., p. 132; Bourne and Benton, American History, p. 85; Bourne and Benton, History of the United States, p. 140; Burnham, op. cit., pp. 113, 121; Elson, op. cit., p. 122; Evans, op. cit., p. 180; Fish, op. cit., p. 125; Fite, The United States, p. 140; Forman, op. cit., p. 116; Guitteau, History of the United States, p. 108; Guitteau, Our United States, p. 144; Halleck, op. cit., p. 177; Hart, School History of the United States, p. 126; Hart, Nere American History, p. 127; Hulbert, op. cit., p. 129; Horne, The Story of Our American People, I, 318, 328; James and Sanford, op. cit., p. 150; Latané, op. cit., p. 93; Lawler, op. cit., p. 171; Leonard and Jacobs, op. cit., p. 149; McCarthy, op. cit., p. 159; McLaughlin, op. cit., p. 143; McLaughlin and Van Tyne, op. cit., p. 144; Mace, op. cit., pp. 144-45, 154; Mace and Bogardus, op. cit., pp. 114, 118-19; Muzzey, op. cit., pp. 99, 107; O'Hara, op. cit., p. 126; Robbins, op. cit., pp. 110-11; Stephenson, op. cit., pp. 141, 146; Tryon and Lingley, The American People and Nation, p. 166; West, History of the American People, p. 192; West, The Story of Our Country, p. 152; Woodburn and Moran, op. cit., pp. 138-40; Barker, Webb, and Dodd, op. cit., p. 170.

${ }^{30}$ Estill, op. cit.; McMaster, op. cit.; Thompson, First Book in United States History. 
7 per cent of our histories today failing to note this point, whereas ten years ago over 33 per cent were guilty of the omission. ${ }^{40}$

True it is that many of the textbooks, in pointing out opposition in England to King George's plan, are not explicit in showing its real significance, but tend rather to establish more firmly a belief in the righteousness of colonial resistance. Yet at least they indicate that not all Englishmen were unsympathetic with a struggle for liberty, by all authors admitted to have been just.

Textbook authors have likewise pointed out that sentiment on this side of the Atlantic also lacked unanimity. Unfortunately, in some books this disagreement between upholders and opponents of England's policy is not described in such way as to create in the pupil anything but antagonism for the former and admiration for the latter. Where it is indicated that the struggle was of such a nature that honest men could differ in opinion, a far saner attitude toward the struggle will result than has been held by many in the past. Thus, Muzzey tells his readers:

This great event [the American Revolution] has sometimes been represented as the unanimous uprising of a downtrodden people against a tyrannical attack on their liberties. But there were many thousand Tories in the American colonies who agreed with a noted lawyer of Massachusetts that the Revolution was a "causeless, wanton, wicked rebellion," and there were thousands of Whigs in England who applauded Pitt's denunciation of the war against America as "barbarous, unjust, and diabolical." It is evident from these that on each side of the Atlantic, opinion was divided as to colonial rights and British oppression. ${ }^{41}$

While describing a divergent loyalty by which they show that opinion neither in England nor America was co-ordinated, some textbooks make the Tories or Loyalists objects of contempt. This often occurs, not so much in the written word, as by innuendo. Indeed, the pupil is made to feel "that our war for in-

${ }^{40}$ See Altschul, The American Revolution in Our School Text-Books, pp. 21, $153-68$.

${ }^{41}$ Muzzey, op. cit., p. 90. See also Woodburn and Moran, op. cit., pp. 139-40; McLaughlin, op cit., pp. 151-52. 
dependence was a very difficult one to win, because the patriots led by Washington and his associates were fighting, not only against the British army, but also against a large Tory faction at home," many of whom "spied upon the American troops, gave information to the British, and sold them much-needed supplies."42

The American Revolution is frequently found treated as an uprising of a part of the British empire against the home government in an effort to maintain self-government. As the preserver of English liberties, the Revolution, therefore, is held a blessing to the whole English-speaking people. From this standpoint alone if not from others, justification of colonial resistance would be established. As Woodburn and Moran put it, "Royal rule received a set-back everywhere and popular rights were advanced." ${ }^{43}$ For, according to many historians,

The American Revolution is seen imperfectly, if it is looked upon solely as a struggle between England and America. It was a strife of principles. It was a part of a thousand-year-long contest between the English-speaking people and their kings for more political liberty. In 1776 the most advanced part of that people lived on this side of the Atlantic. The popular claims were made here and the struggle was fought out here.....44

The character of the political rights inherited by all people of English descent and brought to America by the colonists does not escape attention. According to textbook writers, these "immemorial rights" of Englishmen were held in sacred regard by the colonists. Any attempt to alter them or trespass upon them was held as dangerous to the liberty for which they had come. ${ }^{45}$

The gradual acceptance of political theories not common then in England is also given by authors such as Fish, Beard, and

42 Burnham, op. cit., p. 137. Some textbooks point out that some Tories "were honorable men who believed it their duty to uphold the king."

${ }^{43}$ Woodburn and Moran, op. cit., p. 140.

${ }^{44}$ West, History of the American People, pp. 192-93. See also, among others, Horne, op. cit., p. 319; Long, op. cit., p. 151; McLaughlin, op. cit., p. 153.

${ }^{45}$ For example, see Muzzey, op. cit., pp. 90-91; Fish, op. cit., p. 24; Bourne and Benton, American History, pp. 44-50. 
Channing as a cause in widening the breach between England and the colonies. The doctrine of natural rights, as set forth by John Locke in the seventeenth century and adopted by the colonists in the eighteenth, "was as English as the constitutional argument," according to Beard. ${ }^{46}$ Yet few historians, even among the writers of senior high school textbooks, point out how the colonial leaders turned to the political theories of Locke when unable to carry conviction through the "immemorial rights" of Englishmen.

Without doubt the descriptions of the hardships endured, the battles fought, and other heroic exploits of the war stir the emotions more than any other phase of the Revolution. It is here that authors have most deftly employed their powers of description. Consciously or unconsciously, they have used their rhetorical faculties to the degree that sympathies are quickened and hatreds aroused. Who is not moved by the heroism of Paul Revere? What child does not see in fancy the lights in the church tower? Surely pulses beat more rapidly at the picture of "The Spirit of "76." And who is not moved by the words of Patrick Henry:

The war has actually begun. The next gale that sweeps from the North will bring to our ears the clash of resounding arms. Our brethren are already in the field. Why stand we here idle? . . . . Is life so dear or peace so sweet as to be purchased at the price of chains and slavery? Forbid it, Almighty God! I know not what course others may take; but as for me, give me liberty or give me death $!^{48}$

Critics who recently questioned the patriotism of textbook writers because of a failure to include heroic characters and incidents in their histories could not have looked into these books. One of the characters alleged to have been omitted was Paul Revere. Yet an examination of those textbooks most commonly

${ }^{46}$ Beard, op. cit., pp. 95-96; Fish, op. cit., p. 133; Channing, A Students' History of the United States, pp. 114-15.

"See, for example, Woodburn and Moran, op. cit.; Horne, op. cit., Vol II.

${ }^{48}$ Muzzey, op. cit., p. 110; Hart, Neze American History, p. 153; Latané, op. cit., p. 124; Garner and Henson, op. cit., p. 167; West, The Story of Our Country, p. 161. 
used finds the story of his ride chronicled in many. Nor are there lacking the details tending to rouse the emotions. ${ }^{49}$

At no place do colonial troops suffer in comparison with British regulars. For example, at Lexington "a determined little band of minute men" awaited British regulars. To Major Pitcairn's "Disperse you villains," they "stood as motionless as a stone wall." At Concord the British again met the "stubborn resistance" of the colonial force, and "were compelled to retreat. 950

At Breed's Hill, the British twice "were driven back by the deadly fire of the untrained militia who coolly stood their ground until they saw the whites of the enemy's eyes." When forced to abandon the intrenchments, the Americans are said to have "retired in good order, leaving over 1,000 redcoats killed or wounded." With others, Muzzey points out that although technically a defeat it was "virtually an inspiring victory for the Americans," $" 51$ for

On came the British. All was silent behind the breastworks. A thousand eyes were sighting the barrels, each with its man picked out. A thousand fingers presse 1 the firelocks ready to pull at the word. The courage shown was wonderful. "Don't fire until you see the whites of their eyes," said the American commander.

The word was given, "Fire!" There were a few seconds of the

${ }^{49}$ Pratt, America's Story for America's Children, V, 62-71; Elson, op. cit., p. 133; Burnham, op. cit., p. 128; Gordy, op. cit., pp. 138-39; Horne, op. cit., I, 340; Long, op. cit., p. 169; Halleck, op. cit., p. 179; Estill, op. cit., pp. 158-59; Hall, Smither, and Ousley, History of the United States, p. 137; Fite, History of the United States, p. 120; Muzzey, op. cit., p. 105. This list includes histories in use from the elementary grades through senior high school.

${ }^{50}$ Hall, Smither, and Ousley, op. cit., pp. 137-38; West, The Story of Our Country, pp. 162-63; Muzzey, op. cit., pp. 105-6; McLaughlin, op. cit., pp. 154-55; Long, op. cit., pp. 169-70; Bourne and Benton, History of the United States, pp. 150-51; and others.

${ }^{51}$ Muzzey, op. cit., pp. 110-11. See also Fite, History of the United States, pp. 122-23; Pratt, op. cit., II, 69-73; Stephenson, op. cit., pp. 167-68; Woodburn and Moran, op. cit., pp. 134-35; Mace, op. cit., pp. 158-59; McCarthy, op. cit., p. 166; McMaster, op. cit., 129-30; Guitteau, History of the United States, pp. 129-30; Halleck, op. cit., p. 183; Evans, op. cit., pp. 191-92. 
rattle of musketry; a cloud of smoke floated back; powder horns were lifted; bullets were rammed home. This was inside the works. Outside, lay the harvest rows of death. The advancing line had melted. It was broken as a wave is broken when it strikes the rocks. The British soldiers who had come on in martial pride fell back in terror.

Again urged on, threatened, beaten with swords, the British formed and charged. Again the cool marksmen behind the breastworks swept them out of life. Now came a time of danger to the Minute-men. Their powder was gone, and if the British should charge again, they would win.

More troops came from Boston, and the third charge was made. It swept the patriots from the hill, and they fell back to escape capture. It was a costly victory for the British, who lost eleven hundred and fifty-four; the Continentals, four hundred and fortynine. ${ }^{52}$

Descriptions of the winter at Valley Forge afford an opportunity to kindle again the sympathies of pupils as they read of the sufferings endured. According to Beard and Bagley's History of the American People, which presents a typical picture,

The soldiers were in rags and half-starved all the time. Half went without shoes and blankets, and seldom did they have anything but the coarsest food. Lafayette, the young Frenchman who had come over the sea to dedicate himself to the cause of liberty, wrote of Valley Forge: "The unfortunate soldiers were in want of everything; they had neither coats, hats, shirts, nor shoes; their feet and legs froze until they became black.... The army frequently remained whole days without provisions and the patient endurance of both officers and men were a miracle." An undying faith in the justice of their cause and in the wisdom and ability of Washington kept the remnants of an army together..$^{53}$

An anecdote frequently appearing in readers and occasionally found in histories is that of Marion and the British officer who dined with him. It is typical of discussions portraying the hard-

${ }^{32}$ Barnes, American History for Grammar Grades, pp. 195-96.

${ }^{53}$ Beard and Bagley, op. cit., pp. 153-54. See also Thompson, A History of the People of the United States, p. 149; Stephenson, op. cit., p. 188; Woodburn and Moran, op. cit., p. 149; Hall, Smither, and Ousley, op. cit., pp. 15\%-58; Channing, Elements of United States History, pp. 155-57; West, Story of Our Country, pp. 176-77. 
ships suffered by the American soldiers in their struggle for liberty.

A British officer, so the story goes, visited Marion's camp, under a flag of truce, for the purpose of arranging an exchange of prisoners. Marion invited the officer to dine. There was neither chair nor stool; so the host and his guest sat on the trunk of a fallen tree. When the dinner was brought, it proved to be sweet potatoes served on pieces of pine bark.

"Surely," said the officer, "this is not your usual fare?"

Marion bowed and replied, "Yes, and as we have company for dinner, we are lucky to have a larger supply than usual."

The officer was astonished. When he returned to the British camp, he told his comrades that it was useless to wage war against such determined men. Poorly clad and poorly fed, they would fight to the death for the sake of liberty. And he resigned from the army. ${ }^{54}$

Many instances of the use of adjectives describing the troops as courageous, brave, patriotic, and unselfish might be given. For example, at Yorktown they achieved "a noble victory" $;$ " the campaign in the South was "one of the most brilliant in American history" ;6 the victories at Trenton and Princeton were "remarkable feats" ; ${ }^{57}$ and King's Mountain" a splendid victory.",58 It was "brilliant skill and dogged persistence" that at another time held back the British. ${ }^{59}$

On the other hand, equal praise is not given to the foe. "The British in their very cruelty, had aroused the people to resistance," one author avers in his discussion of the campaign of the South. "Britain's haughty treatment of other nation's ships at sea," according to The Story of Our American People, aroused the animosity of "almost all the world." The war in the West,

s4 Thompson, First Book in United States History, pp. 224-25.

${ }^{55}$ Elson, op. cit., p. 174.

${ }^{56}$ Halleck, op. cit., pp. 208-9.

${ }^{57}$ Fite, History of the United States, p. 138.

${ }^{58}$ Thompson, First Book in United States History, pp. 225-26.

so Horne, op. cit., I, 314.

${ }^{60}$ Thompson, First Book in United States History, p. 223.

${ }^{61}$ Horne, op. cit., ${ }^{\text {Fp. }} 383$. 
"more savage than military" marked by "brutal and senseless" raids, is thus characterized by Long and others. ${ }^{62}$

Where adjectives of praise are employed in discussing the British soldiers, the effect is often that of strengthening an impression of the unusual valor of the Americans rather than ascribing a virtue to the English. Thus, "Twice the courageous English soldiers dashed up the hill only to be repulsed by the deadly fire of the patriot marksmen." "63

Not only was the American army a worthy opponent for the British soldiers, but American ships "played havoc with the British merchantmen." The superiority of the Americans is demonstrated to the reader in such discussions as that of the "Ranger," which "prowled about the coasts of Great Britain, took several merchant prizes, captured a British warship which carried more guns than the Ranger, and even burned some of the shipping in a port on the coast of England. 965

Throughout, the discussions of the Revolution show, as The Story of Our American People puts it, "our people's courage and endurance." ${ }^{\text {"66 }}$ Stephenson declares:

We study the wars in which our country has been engaged, first, because the courage and self-sacrifice of our ancestors serve to inspire us with a like devotion to duty, even if need be, to the laying down of our lives; and second because they are precious lessons in how to defend ourselves. ${ }^{67}$

Of all the concepts gathered from a study of the Revolution, that of liberty will be the strongest and most indelibly stamped in the child's mind. In the discussion of the political aspects of the war, in the military movements, and in the social and psychological phases, liberty is the purpose of the struggle. Abstract discussions are attended by stories such as that of Sergeant Jasper. ${ }^{68}$ If we believe the textbook writers, it is for liberty

${ }^{62}$ Long, op. cit., p. 196.

${ }^{63}$ Hall, Smither, and Ousley, op. cit., p. 141.

${ }^{64}$ Elson, op. cit., p. 167.

${ }^{66}$ Horne, op. cit., p. 413.

${ }^{\text {es }}$ Burnham, op. cit., p. 148.

${ }^{67}$ Stephenson, op. cit., p. 176.

68 "For twelve hours a storm of steel broke over the little fort [Fort Moultrie], which answered with all its guns. In the midst of the bombardment the flagstaff was splintered, and the blue flag of South Carolina bear- 
that America fought then; it is liberty which America has exemplified since.

When, in 1917, Charles Altschul made his study of the American Revolution in fifty-three textbooks then in use, he divided these histories into five classes: those dealing fully with the grievances of the colonists, giving an account of general political conditions in England prior to the American Revolution, and giving credit to prominent Englishmen for services rendered America; those dealing fully with the grievances of the colonists, which make some reference to general political conditions in England prior to the American Revolution, and which mention some prominent Englishmen who rendered services to the Americans; those dealing fully with the grievances of the colonists, which make no reference to general political conditions in England prior to the American Revolution, but make, at least, favorable mention of several prominent Englishmen; those dealing fully with the grievances of the colonists which make no reference to general political conditions in England prior to the American Revolution, but mention, at least, Pitt; those dealing fully with the grievances of the colonists, which make no reference to general political conditions in England prior to the American Revolution, nor to any prominent Englishmen who devoted themselves to the cause of the Americans.

In the first group, Mr. Altschul found six books; in the second, fourteen; in the third, thirteen; in the fourth, five; and in the last group, fifteen. That is, the greatest number of the books which he analyzed gave only the colonial viewpoint in the struggle between England and America. ${ }^{69}$

More than ten years have passed since Mr. Altschul's study was made. Although faith in the justice and wisdom of the patriot cause is undiminished, textbooks used most frequently

ing the white word 'Liberty' fell outside the walls. After it leaped a boy, William Jasper. Hardly seen for the smoke of bursting shells, he wrapped the flag around his shoulders, climbed the wall, planted the broken staff among sand bags, and dropped back among his comrades, leaving 'Liberty' afloat above him" (Long, op. cit., p. 174).

${ }^{69}$ Charles Altschul, op. cit. 
today may be grouped in Mr. Altschul's first two classes. On the whole, the histories of today cannot be criticized for setting forth only the viewpoint of the colonials.

Yet the patriot cause does not meet a real challenge even in the most impartial narratives. Throughout, the reader is convinced that the colonists were right. On the other hand, the lack of detail in discussing the English attitude, even in those books dealing most fully with it, may account for the reaction of the reader. For some pupils, undoubtedly, the discussions of Burke, Fox, Pitt, and others favorable to the American cause will strengthen the antagonism toward the English, since even some of the English themselves approved of the colonial cause! The discussion of the Loyalists in America seldom will off set this impression.

But it is a question as to whether the controversy can be better or more fairly treated in the narrow limits of a textbook than it has been by historians such as Muzzey, McLaughlin, Beard, West, and others. Whether the pupil will conclude that the patriot cause was indisputably right will lie, not only with the historian, but also with the teacher who presents the written word. The textbook writer surely is not entirely responsible for the attitudes gained. In nearly all passages, even where impartiality has been evinced by author, explanation and interpretation by teacher will be necessary in view of the controversial character of the subject and because of the inherited antagonism toward Great Britain held by many pupils. As one college student, in assessing the responsibility for his dislike of Russia, said:

This dislike was formed partly, I think, because my instructor (in history) had this dislike. She had traveled in Russia and disliked it, and transmitted this dislike to me. But at the same time she liked France so very well that this country was brought to my liking. Before this time I had no particular liking for France.

Textbook narratives of the period following the American Revolution describe conditions in such a way as to continue the impressions gained up to that point. Instead of "wisely seeking to conciliate and win us, [England] was exasperating in the 
extreme," declares McLaughlin, in A History of the American Nation. He further explains that as a "weak" nation England long refused to treat us as an equal. Not till 1791 did she send a minister to this country. The treaty of 1783 had not been fulfilled by either party. England retained possession of the military posts on our Northern and Western frontier within the limits of the United States. She gave as her excuse that, contrary to the treaty, the loyalists had been persecuted and the British creditors prevented from collecting sums due them by American citizens. Her chargesat least during the time of the Confederation-had too much truth in them; but her main reason for retaining the Western posts was her desire to control the fur trade and to maintain her influence over the Indians. ${ }^{70}$

Similar discussions relating to our relations with Great Britain in the period directly following the Peace of Paris are found in other histories. Guitteau points out that "foreign countries treated the new nation with contempt. Great Britain declined to make a commercial treaty with a government powerless to compel its thirteen states to observe the agreement." Some of the textbooks place the blame, at least to some extent, on the weakness of the government under the Articles of Confederation. ${ }^{71}$

In 1793, when France and Great Britain engaged in war, it was thought, historians tell the pupils, that "our country would find itself on the side of France."72 The Genêt episode occurred, followed by the Neutrality Act. ${ }^{73}$ Then come discussions pointing out the great opportunity for trade which was opened to America. "Never had we such a chance of making money," declares Fish. Yet in this the Americans were foiled by their old enemy England. "The British government wished to prevent this trade," continues this author, "and maintained that international

${ }^{70}$ McLaughlin, op. cit., pp. 209, 211.

${ }^{71}$ Guitteau, Our United States, pp. 217-18. See also Long, op. cit., p. 236; Channing, Elements of United States History, pp. 176, 191; Elson, op. cit., pp. 217-18; Barnes, Short American History, p. 115; Muzzey, op. cit., p. 138; Gordy, op. cit., p. 176; Forman, op. cit., p. 199; Woodburn and Moran, op. cit., p. 169.

${ }^{72}$ Fish, op. cit., p. 201.

${ }^{73}$ Treated in other sections of this study. 
law allowed them to do so. In the spring of 1794, the British seized a hundred and fifty of our ships. We maintained that the trade was legal, and demanded that the ships be released." "74

On the whole, the Jay Treaty is said to have been "a fairly good treaty,"75 "probably the best that could have been made under the circumstances," Its reception in America is recounted by many books, as well as the fact that it did not settle all of the disputes between Great Britain and the United States. "In time, however," says The Story of Our American People, "everyone came to see that this was the best possible treaty for us. It increased our shipping trade enormously, and it enabled us to postpone honorably for twenty years our second unavoidable war with Britain."78

The impressment of American seamen is given as the chief cause of our second war with England, called by Horne and others "the second war for independence"; a war which was "a story of outworn patience, and of mistakes which ended in unexpected fortune" $;^{79}$ a "war for the freedom of our seamen.",80

The pictures drawn of the cause for desertion from Great Britain's service make her indeed a hard taskmaster. The following quotations illustrate the cruelty, the harshness, and the unfairness of the British as set forth in many of our histories:

More than six thousand naturalized Americans had thus far virtually been enslaved in Great Britain's navy, with poor food, low wages, and harsh treatment, and they were obliged, under threat of severe punishment, to assist in annoying their fellow countrymen. No

"Fish, op. cit., p. 202. See also Guitteau, History of the United States, p. 204; Beard, op. cit., p. 177; Leonard and Jacobs, op. cit., p. 232; Lawler, op. cit., p. 242; Robbins, op. cit., p. 196; Hall, Smither, and Ousley, op. cit., p. 198; Mace and Bogardus, op. cit., p. 182. The treatment of the period is similar in most textbooks.

${ }^{75}$ Fish, op. cit., p. 203.

${ }^{76}$ Thompson, A History of the People of the United States, p. 200.

${ }^{77}$ Guitteau, Our United States, p. 247; Hall, Smither, and Ousley, op. cit., p. 198; Beard and Bagley, op. cit., p. 197.

${ }^{78}$ Horne, The Story of Our American People, II, 29. See also Thompson, History of the People of the United States, p. 200; Burnham, op.cit., p. 208.

${ }^{79}$ Horne, op. cit., p. $80 . \quad{ }^{80}$ Estill, op. cit., chapter title. 
doubt some of these kidnapped men actually were deserters from the British navy, as its officers claimed; but the majority were really Americans, and were taken simply because the British wanted these able-bodied fellows for their own ships [Thwaites and Kendall, $A$ History of the United States, p. 250].

In order to do this [impressment], the British often stopped the vessels of other nations at sea and marched the crews before the British officers, who picked out supposed deserters or British subjects and forced them into British ships. American vessels were so treated almost from the founding of our government, and it often happened that through mistake, or carelessness, or wanton insolence, American-born citizens were dragged from their own ships and forced into the service of the king. Again and again as the years passed the United States protested against the practice, but did not feel strong enough to make absolute demands. But a time was coming.

It is true that Great Britain had reason to be alarmed at the numerous desertions from her navy, but it was her own fault. She treated her sailors so harshly and paid them so meagerly that great numbers of them escaped when they could. Sometimes a British vessel could hardly depart from an American port owing to the many desertions of her crew. Better treatment and larger pay in the American ships had greater weight with Jack Tar than his allegiance to his own sovereign. More than once the American government offered to make a treaty with Great Britain for the return of deserters from both sides, but she preferred to carry on her practice of forcible impressment [Elson, United States: Its Past and Present, pp. 264-65].

All histories analyzed give as the primary purpose of the struggle the abolition of the practice of impressment. In many textbooks the desire to annex Canada is mentioned as an accessory motive, and many charge France, as well as England, with a violation of our rights as a neutral nation. Yet England is made the greater transgressor. As Barnes, in his American History for Grammar Grades, puts it:

England and France held to their evil course toward our country during Madison's first term. England was very abusive. By this time, fully a thousand of our trading vessels had been taken by the English navy, and thousands of good American sailors were serving against their will in English warships. They were like slaves, com- 
pelled to fight for their masters, and flogged if they did not work well..... Insults and outrages from England could be borne no longer, and, though the United States was in no condition for fighting, war was declared against England in June, 1812. ${ }^{81}$

Horne, in The Story of Our American People, however, does not make England the greater offender but says: "Upon the whole France treated us rather the worse of the two; but Britain was the more openly defiant about it." ${ }^{92} \mathrm{He}$ also attributes a perplexity to the American people as to which country, they should fight, a problem finally solved by our nearness to Canada and "the traditions of democracy," which still leaned toward friendship with France, "despite the excesses of her Revolution." Although many authors indicate that a longing to possess Canada actuated some Americans in the selection of a foe, yet it is seldom asserted that France harmed us more than did Great Britain.

The desire for Canada is ascribed to westerners like Clay and Calhoun as an impelling motive in making war on England. It is due to their influence, then, the pupil is told, that Madison, a lover of peace like Jefferson, was forced into war. ${ }^{84} \mathrm{By}$ other authors Canada is mentioned as a deciding factor in the selection

${ }^{81}$ Barnes, American History for Grammar Grades, p. 254. See also, among others, Leonard and Jacobs, op. cit., p. 250; Halleck, op. cit., p. 256; Latané, op. cit., p. 226; Burnham, op. cit., p. 235; Hall, Smither, and Ousley, op. cit., p. 217. "It [impressment] was a towering insult. Although France followed the same practice to some extent, her offenses along this line were not to be compared with those of Great Britain" (Fite, The United States, p. 206).

${ }^{82}$ Op. cit., II, 74 .

${ }^{83}$ Ibid., p. 82. Other authors also indicate that France was still held in a more favorable light, owing to her help in the Revolution. See Halleck, op. cit., p. 261; Beard, op. cit., p. 199; Fite, History of the United States, pp. 196, 229.

84 Bourne and Benton, American History, pp. 253-54; Beard and Bagley, op. cit., p. 222; Beard, op. cit., p. 199; Burnham, op. cit., pp. 240-41; Channing, A Students' History of the United States, p. 300; Fite, History of the United States, pp. 229-30; Fite, The United States, p. 209; Franciscan Sisters of the Perpetual Adoration, op. cit., p. 299; Hart, School History of the United States, p. 205; Hulbert, op. cit., p. 221; James and Sanford, op. cit., p. 259; Latané, op. cit., p. 235; McLaughlin and Van Tyne, op. cit., p. 262; McLaughlin, op. cit., p. 245; Muzzey, op. cit., p. 184; Thompson, First Book in United States History, p. 245; Tryon and Lingley, op. cit., p. 279; West, History of the American People, p. 399. 
of a foe because of her nearness to attack, or because "it was generally believed that British agents in Canada were guilty of stirring up the Indians against our settlements on the frontier." 85 The last group of writers do not attribute, either openly or covertly, land-hunger to the "War Hawks" in Congress. According to Elson, "It was not so much land-greed that led to desire of the invasion of Canada; it was more a belief that it would put an end to Indian massacres, supposed to be inspired by British fur-trading interests." 88

As in most wars, the War of 1812 arose out of a need to protect national honor, according to some historians. "There seemed no honorable way for averting war with Great Britain," declares Thompson. "President Madison was a man of peace, but he was forced to go to war to uphold the honor of his country and to protect her rights," assert Woodburn and Moran. And Hulbert points out that England's treatment was looked upon "as an indignity no respectable nation could endure." ${ }^{87}$ Yet some authors doubt the wisdom or the timeliness of the selection of the foe, for, as Hart puts it:

It was an unlucky moment to make war against England, for in 1812 the Russians grew tired of the Continental System and refused any longer to support France. Napoleon therefore raised a "Grand Army" of 550,000 men and led them into the heart of Russia. However unfairly England had acted toward the United States, the English were fighting in 1812 for the freedom of Europe and America, against a military despot who was trying to make himself absolute master of Europe.

${ }^{85}$ Elson, op. cit., p. 273; Channing, Elements of United States History, p. 218; Fish, op. cit., p. 208; Forman, op. cit., p. 227; Guitteau, History of the United States, p. 238; Guitteau, Our United States, p. 271; Garner and Henson, op. cit., p. 259; Hart, Nere American History, p. 254; Horne, The Story of Our American People, II, 84; Mace and Bogardus, op. cit., p. 197; Mace, op. cit., p. 246; O'Hara, op. cit., p. 214; Stephenson, op. cit., p. 250; West, The Story of Our Country, p. 256; Woodburn and Moran, op. cit., p. 232.

${ }^{86}$ Elson, op. cit., pp. 274-75.

${ }^{87}$ Thompson, History of the People of the United States, p. 213; Woodburn and Moran, op. cit., p. 234; Hulbert, op. cit., p. 221. See also Fite, The United States, p. 209; West, History of the American People, p. 395. 
The time was unfortunate also within the United States. The Federalists, after saying that "the administration could not be kicked into a war," now voted and worked against war; for they knew that England would have a right in war time to capture any American vessels found at sea. Many of the Republicans in the Middle States also were opposed to the war.... The country was divided, and a large number of the people were opposed to war with England. ${ }^{88}$

From an international point of view, the War of 1812 was a terrible misfortune [says Channing]. Great Britain was then engaged in a deadly struggle with the military despotism that threatened to overwhelm popular freedom wherever it existed in the world. . . . . True policy dictated the alliance of Great Britain and the United States to destroy the master despot of the age. ${ }^{89}$

According to West,

Our government shilly-shallied, in impotent indecision (between 1806 and 1810), until the energetic part of the nation rose wrathfully to demand that we fight someone at once to win back selfrespect. Then we chose the wrong time, and apparently the wrong foe. Unfortunately, too, our choice of a foe arrayed us on the side of the European despot against the only hope for European freedom. ${ }^{90}$

The difficulties of communication of the time are given by Halleck, West, Barnes, McMaster, and Elson as a contributory cause in the declaration of war. "If there had been an Atlantic cable, the conflict might have been avoided," declares Halleck. "Had there been less haste it would have been better, for, no doubt, a peaceful settlement could have been made," is the statement of Barnes. ${ }^{91}$

In the actual military engagements between England and America, most textbook writers indulge in glorifying our heroes,

${ }^{88}$ Hart, School History of the United States, pp. 205-6.

${ }^{89}$ Channing, A Students' History of the United States, p. 309.

${ }^{90}$ West, History of the American People, pp. 395-96.

${ }^{21}$ Halleck, op. cit., p. 261; West, History of the American People, p. 399; West, The Story of Our Country, p. 257; Barnes, Short American History by Grades, p. 151; McMaster, op. cit., p. 231; Elson, op. cit., p. 273; Muzzey, op. cit., p. 184. These are merely examples. 
in condemning the tactics of war employed by the enemy, and in proclaiming our superiority as fighters although greatly outclassed in material resources.

Although preceding the declaration of war, descriptions of the Chesapeake and Leopard affair establish an attitude of hostility. "Such a wanton insult to the American flag had not occurred since the nation was founded," says Elson.92 For "this outrage," 93 according to other authors, the "British government made a half-hearted apology."94 The discussion attending this episode as given by Gordy and Guitteau is an example of how two authors can engender entirely different attitudes in a discussion relating to the same event:

The Chesapeake, not being in a condition to make resistance, surrendered. She was boarded and four of her crew were arrested as deserters and taken on board the Leopard. Three of these afterward proved to be Americans and were released. The people were deeply offended and in some quarters there was a clamor for war. As the country was not prepared at that time for open hostilities, Jefferson went no further than to enter a protest, and warned British men-ofwar to leave American waters. In return, the British Government made a half-hearted apology although it declared its purpose to continue the impressment of seamen [Gordy, History of the United States, p. 220].

The entire country was stirred by this outrage, and there were loud demands for war. President Jefferson resisted this demand, for he reasoned that the act was that of the British admiral alone, and was probably unauthorized by his government. To allay popular resentment, the President issued a proclamation ordering all British warships out of American waters. He also instructed our minister at London to demand a disavowal of the act and restoration of the men impressed. The British government complied with this demand, restored the impressed seamen to the deck of the Chesapeake and paid a money award to the wounded soldiers and to the families of those slain. Great Britain announced that she did not claim the

${ }^{22}$ Elson, op. cit., p. 265.

${ }^{93}$ Hall, Smither, and Ousley, op. cit., p. 217; Guitteau, Our United States, p. 265.

${ }^{24}$ Gordy, op. cit., p. 220. 
right to search merchant ships. Thus the Chesapeake affair was due to the blunder of an individual commander, whose act was disavowed by his own government [Guitteau, Our United States, p. 265].

In general, in the discussions relating to battles of the war, the success of American arms is not modestly concealed. Perry's victory on Lake Erie was "a terrific fight . . . . abounding in heroic incidents," a battle which brought about the only recorded surrender of a British squadron; best expressed by the frequently recorded words: "We have met the enemy and they are ours,- two ships, two brigs, one schooner, one sloop."95

Our warships are said to have carried on a "glorious work," repeatedly defeating "Britain's world-winning ships in equal battle," by "the superior shooting of our men." "In the first six months of war we captured more warships from Britain than she had surrendered to all the world in twenty years against France and Europe," says Horne. ${ }^{97}$ Indeed, the Americans were such dangerous and courageous foes that, according to this same author, an "astounded" British officer after another combat wrote home, "God deliver us from our enemies, if this is the way they fight!"98

At Horseshoe Bend, Jackson and his "straight-shooting backwoodsmen" in "a whirlwind campaign" smashed the Indian power of the South. ${ }^{99}$ Then, according to one writer, followed a campaign of "terrorism" against our coast towns. In a spirit of "vandalism," for "which no military excuse can be given because none is possible," Washington was burned. ${ }^{100}$

"It [the burning of Washington] was a piece of ruthless warfare which admitted of no defense. Even in England there was a general feeling that the destruction of non-warlike buildings was an outrage inconsistent with civilized warfare," states Evans. ${ }^{101}$

${ }^{25}$ Long, op. cit., p. 264; Muzzey, op. cit., p. 186; Bourne and Benton, American History, p. 256; Fish, op. cit., p. 209; Horne, The Story of Our American People, II, 89. Most histories give the slogan.

${ }^{96}$ Ibid., p. 91.

${ }^{97}$ Ibid., p. 92. See also Long, op. cit., p. $268 .{ }^{98}$ Horne, op. cit., p. 96.

${ }^{99}$ Long, op. cit., p. $264 . \quad{ }^{100}$ Ibid., p. 266.

${ }^{101}$ Evans, op. cit., p. 268. See Barnes, American History for Grammar Grades, p. 260; Burnham, op. cit., p. 247; Guitteau, Our United States, p. 280; Hall, Smither, and Ousley, op. cit., p. 230. 
Mace and Bogardus, Elson, West, McLaughlin and Van Tyne are among the authors who point out that the burning of Washington was a retaliatory measure for the burning of Toronto by Americans. ${ }^{102}$

[In their] raids on peaceable towns [says Long] they [the British] aimed to break the American spirit and bring about the peace of fear. Precisely as in the War of Independence, their effort was to arouse the nation, to strengthen the grim resolve to fight the war out to the bitter end. ${ }^{103}$

The British vessels visited the coasts of Maryland, Virginia, and the Carolinas, more in the character of pirates and plunderers than of honorable soldiers [asserts Daffan]. Ports were blockaded, villages and farm houses were burned, churches looted, and in not a few instances the sick were murdered in their beds. ${ }^{104}$

In 1814, MacDonough “duplicated Perry's glorious feat on Lake Erie," the pupil is told, when "with a few gunboats hastily built he gave battle, and after five hours of fighting destroyed or captured the whole British squadron."105

"His [MacDonough's] superior seamanship enabled him to slacken and then to silence the enemy's fire," says McCarthy, in his History of the United States for Catholic Schools, in which he explains to the pupil, by a footnote, that the captain was of Irish ancestry. "In two hours the most dangerous of the British vessels struck her colors," he continues. "Within half an hour more the other vessels were disabled. About two hundred Americans had been killed and wounded; the losses of the British were at least three hundred."106

In the closing days of the war, so the reader is told, Jackson "with his hard-fighting, straight-shooting Tennessee frontiersmen" and others won an "astounding" victory at New Orleans,

${ }^{102}$ Mace and Bogardus, op. cit., p. 203; Elson, op. cit., p. 286; West, History of the American People, p. 400; McLaughlin and Van Tyne, op. cit., p. 268. See also McCarthy, op. cit., p. 265, footnote; O'Hara, op. cit., p. 221; Thompson, History of the People of the United States, p. 218; Garner and Henson, op. cit., p. 264.

${ }^{103}$ Long, op. cit., p. 266.

${ }^{104}$ Daffan, op. cit., pp. 294-95.

${ }^{105}$ Long, op. cit., p. 266.

${ }^{108}$ McCarthy, The History of the United States for Catholic Schools, pp. 266-67. 
a battle in which the British lost over two thousand men and the American loss was less than a hundred..$^{107}$

It is unnecessary to enter into further detail to illustrate the discussions characteristic of most textbooks. A few authors make clear that "from a military point of view, the War of 1812 was not a great struggle." Muzzey points out that "in the end, the Americans were the worse sufferers by the war," economically, and in its military aspect that eventually "our little navy, in spite of its exploits, had to yield to Great Britain's superiority in numbers." 109

The War originated in blunder. It cost two hundred millions of dollars and thirty thousand lives-besides the incalculable waste and agony that go with war. It was conducted discreditably. And it ended without mention of the questions that caused it. Still it did give a new impulse to Nationality and to Americanism..... Once more we had "whipped England." 110

On the whole, the results of the war are pictured as beneficial. "It made other nations respect our vessels on the seas," it encouraged home manufactures $;^{111}$ it resulted in Great Britain's acceptance of American equality $;^{112}$ it fired the country with the spirit of nationalism $;^{113}$ it gave us commercial independence $;^{114}$ and it showed the world that we "could and would defend our rights."115

The textbook writer, implanting in the pupil's mind the impression that Great Britain had been beaten again by the United States in a struggle for the rights of men, has but strengthened a nationalistic egotism attributed to Americans. It is undoubt-

${ }^{107}$ Horne, op. cit., pp. 103-4.

${ }^{108}$ Forman, op. cit., p. 234. See also Bourne and Benton, American History, pp. 254, 255, 257.

${ }^{109}$ Muzzey, op. cit., p. 187.

${ }^{110}$ West, History of the American People, p. 409.

${ }^{111}$ Barnes, Short American History by Grades, p. 167; Thompson, History of the People of the United States, p. 221.

${ }^{112}$ Hart, School History of the United States, p. 212.

${ }^{113}$ Ibid.; Mace, op. cit., p. 255; Leonard and Jacobs, op. cit., p. 267; McMaster, op. cit., p. 239; McLaughlin, op. cit., pp. 253-54.

${ }^{114}$ Fite, History of the United States, p. 236; Gordy, op. cit., p. 231.

${ }^{115}$ Garner and Henson, op. cit., p. 268. 
edly true that to many may be ascribed a profound belief in American invincibility. For there are not a few who hold that there is no foe whom America could not "whip before breakfast."

Following the War of 1812 until the Civil War, historic accounts do not devote much space to Anglo-American relations. The Rush-Bagot Agreement of 1817 is not discussed by all textbooks, and in those in which disarmament of the Great Lakes region is mentioned, the treaty is often not given by name. Nor is the real significance of the convention stressed. Yet some authors have not failed to call attention to it. ${ }^{116}$ According to West, however,

This humane and sensible arrangement is the nearest approach to disarmament yet reached by international agreement. For the century since, in striking contrast to the constant threat of all European frontiers with their frowning fortresses crowded with hostile-minded soldiery, Canada and the United States have smiled in constant friendliness across the peaceful waters that unite our lands. ${ }^{117}$

In 1818, according to Professor Channing, "an important treaty was negotiated [between England and the United States] in regard to the fisheries and the northern boundary of the United States."118 This agreement and the convention regarding the Oregon country are not unnoticed by frequently used textbooks, including those by West, Bourne and Benton, Thompson, Beard, Forman, and Muzzey. ${ }^{119}$

${ }^{118}$ Bourne and Benton, American History, pp. 268-69; Thwaites and Kendall, op. cit., p. 501; Course with Type Studies, Book IV, p. 74; Fite, History of the United States, pp. 236-37; Fite, The United States, pp. 217-18; Hulbert, op. cit., p. 227; Latané, op. cit., p. 250; Fish, op. cit., p. 212; Long, op. cit., p. 271; Mace and Bogardus, op. cit., p. 205; Lawler, op. cit., p. 276; Hall, Smither, and Ousley, op. cit., p. 240; Halleck, op. cit., p. 269; Stephenson, op. cit., p. 255; West, History of the American People, p. 423; West, The Story of Our Country, p. 263; Guitteau, Our United States, pp. 284-85; Elson, op. cit., pp. 288-89; Bourne and Benton, History of the United States, p. 257.

${ }^{117}$ West, History of the American People, p. 423.

${ }^{118}$ Channing, A Students' History of the United States, p. 320; Bourne and Benton, American History, p. 268.

${ }^{110}$ West, History of the American People, p. 424; Bourne and Benton, American History, pp. 268-69; Thompson, History of the People of the United States, p. 223; Beard, op. cit., p. 284; Forman, op. cit., p. 246; Muzzey, op. cit., p. 266. 
Nor is the influence of England in the pronouncement of the Monroe Doctrine entirely neglected. "Four times Canning, casting about for an effective policy, proposed to the United States a joint declaration against any plan to subjugate the Spanish republics" declare Bourne and Benton, in their textbook for senior high schools. ${ }^{120}$ Muzzey, Channing, Beard, Hart, and others do not pass unnoted this aspect of English interest in a doctrine which came to be purely American. ${ }^{121}$

Few authors explain in so great detail as Bourne and Benton the points of controversy considered in the Webster-Ashburton Treaty; neither is the seriousness of the situation as clearly set forth nor the achievement of the peacemakers. These authors make clear how a latent anti-British feeling in the country was aroused by the issues involved, and how, on the other hand, antiAmerican sentiment grew in England because of the repudiation of debts by American states. The significance of the treaty is, therefore, made the more evident. ${ }^{122}$

In general, the settlement of the dispute over the Oregon territory is said to have "avoided war with Great Britain,"123 and that it was "fair for both countries." 124 Some writers, on the other hand, assert that "not without cause were some of those pioneers angry over the result.".125

The attitude of the governmental group in England during the Civil War, as set forth in our histories, has long rancored

${ }^{120}$ Bourne and Benton, American History, pp. 273-74.

${ }^{121}$ Muzzey, op. cit., p. 206; Channing, A Students' History of the United States, p. 327; Beard, op. cit., p. 206; West, The Story of Our Country, p. 266; McLaughlin and Van Tyne, op. cit., p. 283; Hart, School History of the United States,.p. 241; Woodburn and Moran, op. cit., p. 246. These are samples.

${ }^{122}$ Bourne and Benton, American History, pp. 345-48. See for cusstomary treatment: Fite, History of the United States, p. 310; Fish, op. cit., p. 291; McLaughlin, op. cit., pp. 313-14; Daffan, op. cit., p. 331; Horne, op. cit., II, 168; Hart, School History of the United States, p. 285; Stephenson, op. cit., p. 295. Some textbooks such as Woodburn and Moran, Mace and Bogardus fail to mention the treaty.

${ }^{123}$ Woodburn and Moran, op. cit., p. 306.

${ }^{124}$ Muzzey, op. cit., p. 342; see also Beard and Bagley, op. cit., p. 215.

${ }^{125}$ Mace and Bogardus, op. cit., p. 267. 
in the hearts of northerners. For they have held that "animosity toward the United States and friendship for the Confederacy were plainly displayed in England by the aristocracy, by the majority of the commercial and moneyed classes, and by newspapers." 126

Discussions are focused, in general, about England's recognition of the belligerency of the South, the Trent affair, and the Alabama claims. In the latter connection the Treaty of Washington and the Geneva Award have their part. Substantially all histories deal in a similar vein with these matters. Many of them indicate that cotton played its part in directing the sympathies of Great Britain, and that men like Richard Cobden, John Bright, and Goldwin Smith supported the northern side. $^{127}$

In the Trent affair, "the conduct of Great Britain," according to McMaster, "was most insulting and warlike, and nothing but the justice of her demand prevented war." On the other hand, Stephenson asserts that "Mason and Slidell were not in the Confederate army and so should have been safe against capture."128 The official attitude of Great Britain at this time is said to have been a good opportunity "to embarrass the United States in a time of great difficulty." "129 Not only were England's actions said to have been against "the spirit of fair play," but also contrary to "the laws of nations." "130

In the settlement of the Alabama claims and other disputes through arbitration, authors in several instances have commended to the pupil this method of adjusting international disagreements. 'By arbitrating the 'Alabama Claims,' and other disputes then and since, Great Britain and the United States

${ }^{128}$ James and Sanford, op. cit., p. 401.

${ }^{127}$ A typical treatment is found in Channing, A Students' History of the United States, pp. 470-71.

${ }^{128}$ McMaster, op. cit., p. 413; Stephenson, op. cit., p. 344.

${ }^{129}$ Channing, op. cit., p. 471.

${ }^{130}$ Barnes, Short American History for Grades, p. 272. 
have shown the world that there is a better way than war to settle differences between nations," says Burnham. ${ }^{131}$

The next example of the success of arbitration between the two English-speaking peoples was in the settlement of the seal fisheries controversy which, according to Forman, "led to a dispute so heated as to threaten a break between Great Britain and the United States."132

Histories then discuss the Venezuelan boundary dispute. Here, as in the preceding instances, the effectiveness of arbitration is again mentioned. In practically all books treating the topic, the application of the Monroe Doctrine is explained, as well as the victory gained in the decision. ${ }^{133}$ The statement of Horne, in The Story of Our American People, is:

The Monroe'Doctrine was thus given a new and broader use than ever before, and our government was again brought before the eyes of Europe, as in the Samoan case. We had few foreign interests; but when these were interfered with, we were determined to maintain them even in the face of Europe's greatest warlike Powers. ${ }^{134}$

According to Guitteau a growing friendship between Great Britain and the United States had its influence in the settlement by means of arbitration, ${ }^{135}$ but other authors occasionally use phrases and words which do not put England in a favorable light.

"The brusque attitude of Great Britain aroused our government to an aggressive and spirited course of action," says Forman. ${ }^{136}$ "England's stubbornness," English attempts "to ignore the United States even after Venezuela had asked us to mediate in her behalf to save over twenty thousand acres of mineral lands

${ }^{131}$ Burnham, op. cit., p. 469. See also West, The Story of Our Country, p. 407; Mace, op. cit., p. 396; Thwaites and Kendall, op. cit., p. 415; Fite, The United States, p. 391; Guitteau, Our United States, p. 482; Gordy, op. cit., p. 420.

${ }^{132}$ Forman, op. cit., pp. 493-94.

${ }^{133}$ See Barnes, American History for Grammar Grades, p. 349; Guitteau, Our United States, p. 486.

${ }^{135}$ Guitteau, Our United States. ${ }^{134}$ Op. cit., II, 343.

${ }^{136}$ Forman, op. cit., p. 511. 
in dispute,"137 and England's "indignation"138 are other expressions found.

Yet the excerpt quoted from Thompson's History of the People of the United States is, in general, typical:

For many years there had been a dispute between Great Britain and Venezuela concerning the boundary between British Guiana and Venezuela. Although Venezeula wished to submit the matter to arbitration, and the United States advised such a course, the British government refused to arbitrate. From time to time, Great Britain pushed its boundary line farther into territory claimed by Venezuela. President Cleveland, holding that the action of Great Britain was contrary to the Monroe Doctrine, in 1895 asked Congress for authority to appoint a commission to ascertain the true boundary between Venezuela and British Guiana, and recommended that the United States insist upon the acceptance of the commission's finding. Congress authorized the appointment of the commission, and war clouds for a while hung over the two great English-speaking countries, for unless Great Britain should accept this or some other satisfactory plan of settling the question, it did not seem possible to avoid hostilities.....The British government yielded and the commission of arbitration settled the dispute in favor of Great Britain. ${ }^{139}$

A further effort at arbitration as a means of settling international differences rarely mentioned in the histories was the treaty suggested by England which failed to pass the United States Senate in 1897. ${ }^{140}$

The abrogation of the Clayton-Bulwer Treaty, characterized by Fite as "a grave mistake on the part of the United States,"141 is mentioned in several of the most commonly used textbooks. According to Bourne and Benton, "Since the Venezuela episode of President Cleveland, British statesmen had been anxious to establish more cordial relations with the United States," and "in

${ }^{137}$ Hulbert, op. cit., p. $484 . \quad \quad{ }^{138}$ Latané, op. cit., p. 491.

${ }^{139}$ Thompson, History of the People of the United States, p. 419.

${ }^{140}$ Elson, op. cit., p. 475; West, The Story of Our Country, p. 472.

${ }^{141}$ Fite, History of the United States, p. 325. 
1901 Secretary Hay was able to secure a treaty satisfactory to the United States and Great Britain."142

The favorable attitude of England toward the United States during the Spanish-American War is recounted by a few writers. Here are enumerated events, for instance, in the blockade of Manila, tending to show British sympathy and co-operation with America's undertaking as opposed to evidences of German hostility, ${ }^{143}$ as well as gestures of favorable opinion at the opening of the war.

England as an ally in the World War naturally is accorded nothing but praise. Even in the events preceding our entrance into the war, when occasions for controversy regarding neutral trade are discussed, it is made clear that England destroyed no American lives in enforcing her blockade of Germany. Here is made a sharp distinction between German and English practices. Whereas Germany is charged with committing offenses of the most hideous character in her submarine campaign, England is exonerated in her conduct of the blockade. In the war, the British soldiers are said to have been courageous and daring, evincing a fine spirit of co-operation with their allies in arms. "Today," the pupil is told, "England is a democracy" ;"14 and as "the Mistress of the Seas stands as one of the very greatest of nations," in which "extensive political reforms," made during the century following the American Revolution, have left her as "a most democratic country."

A question can well be raised as to whether the memories of the pupil fired by the usual discussions of the American Revolution and the War of 1812 can be obliterated by abstractions relating to the democracy of England's present government, as-

${ }^{142}$ Bourne and Benton, American History, p. 556. See also Muzzey, op. cit., p. 297; McLaughlin, op. cit., p. 524; Forman, op. cit., pp. 317, 540; Hulbert, op. cit., pp. 297, 354, 504.

${ }^{143}$ Among them are Fite, History of the United States, p. 500; Muzzey, op. cit., p. 462; Latané, op. cit., p. 503; Guitteau, History of the United States, pp. 560-61; Horne, The Story of Our American People, II, 352; Stephenson, op. cit., p. 430; Beard, op. cit., pp. 496-97.

${ }^{144}$ Stephenson, op. cit., p. 157.

${ }^{145}$ Robbins, op. cit., p. 492. 
cription to her of the parenthood of American Institutions, and pronouncements of her friendship for the United States. Those histories which indulge in these discussions have usually attempted a fairness in the portrayal of controversies between the two countries. Unfortunately, they are not all the textbooks used, but in the growth of a spirit of fair play, which Americans claim as a national trait, it is probable that their use will increase. 


\section{CHAP'TER III}

\section{FRANCE IN UNITED STATES HISTORY TEXTBOOKS}

As England is the traditional enemy of the United States, so is France our traditional friend. This attitude is due primarily to her aid during the Revolutionary War. That transcends all other diplomatic contacts either amicable or hostile. Even in the Colonial period, the French Huguenots are described as "a particularly desirable class of settlers and, in proportion to their numbers," as adding "a very great contribution to the making of our country."1

Prior to the opening of the American Revolution, French colonial policy, in general, is characterized by histories in an unfavorable light as contrasted with the English. Attention is also given to the hostile inroads made by the French on colonial holdings as well as their alliances with the Indians against the English. ${ }^{2}$ The vigorous assistance of the colonists in the FrancoEnglish wars during the early eighteenth century has been treated in the previous section of this study, but it may be said again that the French as enemies did not seem as horrible in that rôle as other nations have appeared.

The motives of France in allying herself in the War for American Independence are portrayed by different historians with varying degrees of unselfishness on the part of France. Yet even by those authors who point out that the age-long enmity between France and England doubtless had its influence in inducing the French to take up arms for America, the aid given is acclaimed as generous and valuable.

"True," says McLaughlin, "the French had not entered the Revolutionary War so much for the purpose of helping America

${ }^{1}$ Burnham, The Making of Our Country, p. 66. See also Muzzey, An American History, p. 63.

${ }^{2}$ See, for example, Nida, The Daren of American History, pp. 365-66; Muzzey, op. cit., pp. 72 ff.; Hart, New American History, pp. 37 ff.; Long, America, pp. 130-31. 
as of injuring England, but they seemed to the men of the time generous benefactors."3

The French [declares Fite], since their humiliating losses in the French and Indian War, had been burning for revenge on the British, and were now pleased to see the apparent breaking up of the American empire of their rivals. . . . France concluded a treaty of amity and commerce and another alliance with the struggling states, which she recognized as a free and independent nation. The timely intervention proved the turning point of the war for the United States, for it not only encouraged the new nation, but also secured to them supplies of French guns, ammunition, and clothing, and ultimately the assistance of the French army and navy. ${ }^{4}$

"This court is interested in separating us from Great Britain, but it is not their interest that we should become a great and formidable people," John Jay is quoted by Muzzey as saying about France. To this the author adds: "Yet we were greatly beholden to France. Her aid in men, ships, and money had been so timely and generous that it is almost certain that without it the American cause would have been lost."5 Much gratitude, moreover, is bestowed by textbook authors on the French for this assistance. "This alliance helped to change the world's history," declares Halleck. "We should remember that it is doubtful if we could have secured our independence at that time without the aid of French money and of the French fleet and army."

"This [aid of France] was the real turning point of the war," assert Mace and Bogardus. "It is difficult to see how America could have won her independence without the help of France."7 It is likewise pointed out by Elson that "Cornwallis could not have been captured without French aid," and "it is doubtful if

${ }^{3}$ McLaughlin, History of the American Nation, p. 210.

"Fite, History of the United States, pp. 141-42.

'Muzzey, op. cit., p. 129. See also Beard and Bagley, History of the American People, pp. 156-57; Barnes, American History for Grammar Grades, pp. 200, 215; West, History of the American People, p. 235; McLaughlin and Van Tyne, History of the United States for Schools, pp. 175-76; Bourne and Benton, American History, pp. 139, 142.

${ }^{6}$ Halleck, History of Our Country, pp. 196, 210.

${ }^{7}$ Mace and Bogardus, History of the United States, pp. 134-35. 
Washington could have held his army together during the latter years but for French gold."8

As a result of the French alliance, England found herself without an ally, according to West, for Spain and Holland followed the lead of France. ${ }^{9}$

Without an ally, England found herself facing not only her own colonies, but the three greatest naval powers of the world (next to herself), while most of the rest of Europe, under the lead of Russia, held toward her an attitude of "armed neutrality"-which meant instant readiness for hostility at the slightest opening. ${ }^{10}$

But West goes on to say that "to large numbers of patriots, even the news of the new ally was of doubtful cheer. Many began to fear they had only exchanged the petty annoyances of English rule for the slavery of French despotism and of the Spanish Inquisition."11

Further gratitude to France is aroused in the readers of the histories when they read of Lafayette, who "rendered services of the greatest value to our country."12 $\mathrm{He}$ is the "Good Samaritan who not only gave his services freely but also spent nearly half a million dollars of his own money to assist her [America]."13

The brief naval war of 1798 is mentioned by many of the textbooks, although in general not much space is devoted to it. It was a war in which "about eighty French privateers were cap-

${ }^{8}$ Elson, United States: Its Past and Present, p. 175. See also Beard, History of the United States, pp. 131-32; Stephenson, A School History of the United States, p. 198.

West, op. cit., pp. 235-36.

${ }^{10}$ Ibid.

${ }^{11}$ Ibid., p. 236.

${ }^{12}$ Burnham, op. cit., p. 145. See also Bourne and Benton, History of the United States, p. 180; McMaster, A School History of the United States, p. 149; Evans, The Essential Facts of American History, p. 204; Elson, op. cit., p. 155; Leonard and Jacobs, The Nation's History, p. 177; Estill, Beginner's History of Our Country, p. 166; Beard, op. cit., p. 121; Hall, Smither, and Ousley, History of the United States, p. 159; Garner and Henson, Our Country's History, p. 187; Halleck, op. cit., p. 196; Gordy, Stories of Later American History, pp. 67-69.

${ }^{13}$ Halleck, op. cit., p. 196. 
tured," according to The Story of Our American People, and one in which "Napoleon found us no such easy victims as he had expected." Here again the Americans demonstrated a prowess in arms and an invincibility surprising to the foe, according to Horne. ${ }^{14}$

Prior to the quasi-outbreak of hostilities-such as they were - the episode of Genêt is chronicled; Genêt, who had been sent to "bully us into the conflict" between England and France. ${ }^{15}$ The attitude of the Directorate toward American commissioners at Paris is said by Long and others to have given cause for "desultory conflict," which "went on at sea for two years, without a declaration of war on either side." This had come about, according to Long, because "there could be no dealing with such a government of scoundrels." 16

"She [France] insulted the national dignity by offering, through her ministers, to bribe certain envoys whom the United States sent to her to settle the differences between the two countries," the child is told in Fite's The United States. ${ }^{17}$

"England, indeed, treated us with more consideration than before; but France seemed utterly regardless of how she abused a young nation whom she did not fear, and she was now wroth with the United States because the government had come to terms without her august sanction," says McLaughlin, in speaking of the period directly following Jay's Treaty. ${ }^{18}$

This author also goes on to point out:

French war ships ruthlessly plundered American merchantmen. They had not, on the whole, done so much damage as the English men-of-war, but that was not because the French naval officers lacked the will and desire, but was due to the fact that France was less

${ }^{14}$ Horne, The Story of Our American People, II, 46-47.

${ }^{15}$ Long, op. cit., p. 238.

${ }^{16}$ Ibid., pp. 239-40. Beard and Bagley, op. cit., p. 199. Other references are found in preceding footnotes. Scarcely a history textbook fails to present the points at issue in much this manner.

${ }^{17}$ Fite, The United States, p. 205.

${ }^{18}$ McLaughlin, op. cit., pp. 216-17. 
powerful on the sea than England, and was less capable of injuring neutral commerce. ${ }^{19}$

The attitude of France toward the Jay Treaty, according to Elson, "nearly brought on war." The treatment of Pinckney, followed by the X Y Z affair and preceded by the Genêt episode, as chronicled by this author and others, are not, in any sense, laudatory of France. These accounts may register in the pupil's mind an aversion for the French, but when war was declared in 1812 it was another than France, the pupil is made to realize, who became our antagonist. It is a pretty safe assumption that diplomatic negotiations of even the most unfriendly nature do not impress so profoundly as the assembling of armies and attendant descriptions of actual warfare. ${ }^{20}$

The archtraitor of French perfidy is Napoleon if one reads the histories right. "In his direct relations with the United States," says Hart in his School History of the United States, "Napoleon always showed himself slippery and false. He had not the least idea of courtesy or of keeping promises; hence the Americans often suffered in their dealings with him."21

Few textbooks mention the spoliation claims and the settlement obtained by Jackson. The treatment of this international difficulty is in terms which would engender no animus to France. ${ }^{22}$

${ }^{10}$ Ibid., p. 216. See section on England. Barnes, Short American History by Grades, pp. 127 ff.; Bourne and Benton, American History, pp. 217-24; McLaughlin and Van Tyne, op. cit., pp. $243 \mathrm{ff}$.; Gordy, History of the United States, pp. 197 ff.; West, op. cit., pp. 34. ff.

${ }^{20}$ Elson, op. cit., pp. 221-22; Thompson, History of the People of the United States, pp. 198, 200 ff.; Channing, Elements of United States History, pp. 193, 201; Barnes, American History for Grammar Grades, pp. 245-46; Garner and Henson, op. cit., p. 232; Burnham, op. cit., pp. 206 ff.

${ }^{21}$ Hart, School History of the United States, p. 192. See also among others, Vollentine, The Making of America, p. 135; Mace and Bogardus, op. cit., p. 197; Gordy, History of the United States, p. 223; McLaughlin, op. cit., pp. 241-42; Hall, Smither, and Ousley, op. cit., p. 221; McMaster, op. cit., pp. 229-30; Mace, School History of the United States, pp. 244-45; Baldwin, The Story of Liberty, pp. 233-34; Thompson, op. cit., p. 209.

${ }^{22}$ See, for example, Channing, A Students' History of the United States, p. 371; Bourne and Benton, American History, p. 316; Franciscan Sisters of the Perpetual Adoration, A History of the United States, p. 340; Hart, Nere American History, p. 333. 
The attitude of France in the Civil War receives somewhat casual treatment, and far less space than that devoted to England. In general it is stated that France was favorable to the South for economic reasons and because of her desire for territory in Mexico. In the discussions relating to the latter point, attention is directed to the Maximilian affair, and here the pupil sees not so much hostile action on the part of France as a triumph of the Monroe Doctrine. ${ }^{23}$

Little is made of the attitude of France during the SpanishAmerican War. Long holds a unique place among writers because of his statement that Germany and France united in 1913 to object to American control of affairs in Haiti. ${ }^{24}$

In the entrance of the United States into the World War and the active assistance rendered on the field of battle, it is frequently said that in this way we hoped "to pay the debt to Lafayette." "A part of the meaning of this event," says Mace in speaking of the visit of Viviani, Joffre, and Balfour to this country, "lies in the fact that France in our Revolution sent over Lafayette, De Kalb and Rochambeau. They came to aid Washington in winning our independence. America went to the aid of France and the world in the war for democracy."26

France gave our soldiers a welcome which made every true American proud that we were at last repaying our debt to the land of Lafayette and Rochambeau, the France which had given its blood and treasure to make our country free [declares Guitteau]. Now the young giant of the West was sending its best manhood to fight with France and England and Italy to rescue Europe from the black despotism which hung over the whole world like a pall. For wherever liberty and self-government had developed whether in France, or in

${ }^{23}$ See, for example: Guitteau, Our United States, pp. 480-81; Beard, . op. cit., pp. 478, 479; Long, op. cit., pp. 383-84.

${ }^{24}$ Long, op. cit., p. 479. Guitteau, for example, mentions that "both Germany and France demanded that they be allowed to take control of the customs houses," due to Haiti's financial collapse, and that the United States took over the customs administration to prevent Haiti from passing into the control of her European creditors.

${ }^{25}$ Horne, op. cit., II, 423.

${ }^{26}$ Mace, op. cit., p. 476. 
England, or in the distant Orient, or in South America, there the Imperial German government had been its foe. ${ }^{27}$

Throughout the narrative in comparison with the blackness of Germany's crimes, the action of France in the war is painted a spotless white. France, in accepting a "war which was thrust upon her," gained the "instant and overwhelming" admiration of the world, according to Fite. Dash and bravery and wonderful skill in the art of war were hers. ${ }^{28}$ Surely textbooks in American history are not anti-French. ${ }^{29}$

${ }^{27}$ Guitteau, op. cit., p. 593.

${ }^{28}$ Fite, The United States, p. 424.

${ }^{29}$ It seems unnecessary to duplicate quotations to prove this point. A glance at any of the histories most frequently used will prove it. 


\section{CHAPTER IV}

\section{GERMANY IN AMERICAN HISTORY TEXTBOOKS}

Little space is accorded Germany and her people in American histories prior to our entrance into the World War. Few authors devote any considerable discussion to German immigrants and their contributions to the United States or to diplomatic relations between this country and Germany. Few concepts regarding Germany, as a result, could have been built up in the pupil's mind, so that the chief attitudes formed by reading the textbooks will be those of Germany as an enemy of the most unscrupulous kind.

It should be said, however, that as colonials of the eighteenth century the Germans are described as "quiet, hardworking, frugal and thrifty." "They were very poor when they arrived in America," says Burnham, "but their industrious habits soon brought them prosperity. They were a religious people, honest in their dealings and contented in spirit." "Clannishness" is also attributed to them. This same author in his discussion of early Germans declares that "they wished to remain German and consequently they clung tenaciously to the customs, language and literature of their fatherland."2 According to Beard,

Their clannish habits often irritated their neighbors and led to occasional agitations against "foreigners." However, no serious collisions seem to have occurred; and in the days of the Revolution, German soldiers from Pennsylvania fought in the patriot armies side by side with soldiers from the English and Scotch-Irish sections."3

In the Revolutionary War, the employment of German mercenaries by England reflects upon the English rather than placing the Germans in an unfavorable light. Most textbooks mention the Hessians, but in a manner not to discredit them.

${ }^{1}$ Burnham, The Making of Our Country, p. 66.

${ }^{2}$ Ibid. See also Hulbert, United States History, p. 70; Fish, History of America, p. 98; Beard, History of the United States, p. 10.

${ }^{3}$ Beard, op. cit. 
Among the heroic figures of the war is Baron von Steuben, whose services are extolled in many books. In fact, most authors give the impression that to him is due the credit for providing America with an army able to use the bayonet in a skilful manner.

But thanks to the skill of a noble Prussian officer, Baron Steuben, there came forth from that winter of gloom and suffering (17771778) a new and well-trained army [declares Mace in his School History of the United States]. From the first, Washington had had a hard task to drill his men, for they were mostly militia serving for a short time only and did not like the strict rules of military life. They were the best marksmen in the world, as the British learned on many a battlefield, but they liked the Indian method of fighting, each man for himself.... Steuben, fresh from the army of Frederick the Great, taught the Continentals the fine maneuvers of the Prussian soldiers and the skillful use of the bayonet. ${ }^{4}$

Nor are the services of De Kalb forgotten, who "fell in battle while fighting gallantly for our independence."5

From this point there is practically no mention of Germany until the time of the World War, except references to the Samoan incident, the German attitude toward the Spanish-American War, and the Venezuelan affair, and these do not appear in all the textbooks. It should be said that few writers of American histories do as Bourne and Benton have done in their History of the United States in devoting space to a discussion of affairs in Europe during the revolutionary era there. From a reading of these events in this book, however, the pupil would gather the impression of Germany as a land-grabbing nation, totally oblivi-

4 Mace, School History of the United States, pp. 178-79. See also Elson, The United States: Its Past and Present, p. 155; Leonard and Jacobs, The Nation's History, p. 184; Barnes, Short American History for Grades, pp. 76-77; McLaughlin and Van Tyne, $A$ History of the United States for Schools, p. 178.

'Burnham, The Making of Our Country, p. 145. See also Beard and Bagley, History of the American People, pp. 165-66; Thwaites and Kendall, A History of the United States, pp. 175-76; Channing, Elements of United States History, p. 161; Garner and Henson, Our Country's History, p. 187. These are typical. 
ous to the rights of sister-nations, bent upon dominance by military force.

This new Empire was far different [from what the Revolutionists of 1848 had dreamed of] -it was built on military force. Bismarck, the minister of the Prussian King, once said that "iron and blood," rather than fine speeches, were the surest means of getting what the Prussians wanted. The first act of the new Empire was to tear from France, which had been badly defeated in the war, two border lands, Alsace and a part of Lorraine. ${ }^{6}$

In his discussions preceding the World War, Guitteau, in a chapter entitled "Democracy on Trial in the World War," has ascribed a policy of "aggressive wars" to Bismarck in his attempt to place Prussia in the ascendancy. Out of these three successful wars, says Guitteau,

Modern Germany emerged with boundaries greatly enlarged, and with an implicit belief in war and military force as the best means of advancing her national power. Bismarck's policy appeared fully vindicated, although it was a policy of fraud and trickery as well as of blood and iron. Bismarck had muzzled the press of Prussia, bullied its parliament, and overridden the will of its people; but Germany readily forgave his methods in view of the great material gains from his policy. ${ }^{\text {? }}$

The Samoan dispute, usually discussed as a gesture of American interest in the Pacific, is ascribed by Guitteau to "Germany's jealousy of our growing power" there. ${ }^{8}$ Other authors recount that "serious difficulties arose between the representatives of the two nations" and that men-of-war were dispatched to the island to support the contending nations. ${ }^{9}$ By still other authors the dispute is said to have been attended by an "alarm" of the United States and England as to the extension of German power in

'Bourne and Benton, History of the United States, p. 411.'

'Guitteau, Our United States, pp. 569-70.

s Ibid., p. 485.

${ }^{9}$ Franciscan Sisters of the Perpetual Adoration, A History of the United States for Catholic Schools, p. 513. See also Hall, Smither, and Ousley, A History of the United States, p. 419; Fite, History of the United States, p. 483; Hulbert, op. cit., pp. 483-84: Muzzey, An American History, p. 434. 
the Pacific. ${ }^{10}$ On the other hand, Thompson and others merely mention the treaty agreement made between the powers by which six islands of the Samoan group fell to the United States. ${ }^{11}$

International incidents attending the Spanish-American War are another source of German hostility to the United States, because in this war, "Germany had shown much sympathy for Spain, and the German commander at Manila, Admiral von Diedrich ... . acted toward Americans in a most disagreeable and irritating manner."12 By textbook writers von Diedrich is said to have "repeatedly disregarded the American patrol regulations, and finally landed supplies for the Spaniards in flat opposition to the American blockade." This led to "a brusque protest" from Dewey, and the message to the German commander "that if he wants a fight, he can have it now."13

The reaction of Dewey to the attitude of Germany in the war with Spain, as evinced in the Manila episode, is discussed by Mark Sullivan in his popularly written history, The Turn of the Century, as one of the causes of the adulation heaped upon Dewey. It is mentioned in this study merely to show the trend of the fancies of the American people at the time, kindled in no small degree by such a poem as "Hoch! der Kaiser!" which ends each stanza with the well-known line of "Myself-und Gott."14 It is a question whether in the people's minds the episode at Manila and the general attitude of Germany are associated with a resentment toward the hostility shown the American cause, or whether they merely increase the respect which Americans are

${ }^{10}$ Beard and Bagley, op. cit., p. 546. Other authors, Muzzey, for example, mention at this point the growth of German colonial power.

11 Thompson, History of the People of the United States, p. 450; McCarthy, History of the United States, p. 439; Burnham, op. cit., p. 563; Gordy, History of the United States, p. 430; Garner and Henson, op. cit., pp. 508-9, 538; Robbins, School History of the United States, p. 467.

${ }^{12}$ West, History of the American People, p. 635.

${ }^{13}$ Ibid. See also Fite, op. cit., p. 500; Guitteau, History of the United States, p. 561; Latané, History of the United States, p. 502; Halleck, History of Our Country, p. 436.

${ }^{14}$ Mark Sullivan, Our Times: The United States 1900-1925, Vol. I: The Turn of the Century (New York, 1926), pp. 327-29. 
said to have for themselves. Possibly the attitude of Germany would have made slight impression upon the readers of those histories in which it is described if it had not been for the participation of the United States in the World War, in the discussions of which all evidences of German hostility and perfidy are assembled. It is certain that Germany in this incident is not made a conspicuous culprit by many textbook writers. ${ }^{15}$

One other incident attesting a strained relationship between the two countries may be mentioned before the World War engages our attention. It is the Venezuelan dispute of 1901, in which Great Britain willingly accepted but Germany "refused" arbitration. ${ }^{16}$ It is in discussions attending this incident that Germany is said to have regarded the Monroe Doctrine as a piece of "international impertinence" and to have remained for several days after Roosevelt's demand for the withdrawal of her ships from Venezuelan waters. When withdrawal did take place, it is attributed to the fact that "the American navy at that time was more than a match for the German navy, and it was near at hand in West Indian waters." ${ }^{\text {"17 }}$ Some textbooks do not mention the incident at all, ${ }^{18}$ while others point out only the influence of Roosevelt in effecting a settlement through arbitration, and the episode as an indication of the development of the Monroe Doctrine. ${ }^{19}$

${ }^{15}$ See the sections devoted to England for the mention of England's attitude as contrasted with Germany's in the Spanish-American War.

${ }^{16}$ Forman, Advanced American History, p. 542.

${ }^{17}$ Ibid. See also Horne, Story of Our American People, II, 370-71; Latané, op. cit., p. 525; Bourne and Benton, American History, p. 574; Stephenson, A School History of the United States, p. 432; Halleck, op. cit., p. 490; Beard, op. cit., p. 512. In these books the attitude of Germany is mentioned as changing after the statement of the president that a fleet would appear and force settlement.

${ }^{18}$ McLaughlin, History of the American Nation; Evans, The Essential Facts of American History; Long, America; Gordy, History of the United States; Fish, op. cit.; Channing, A Students' History of the United States; Beard and Bagley, op. cit.; Barnes, American History for Grammar Grades; Robbins, op. cit.; Muzzey, op. cit.

${ }^{10}$ Burnham, op. cit., p. 557; Hall, Smither, and Ousley, op. cit., p. 460; Mace and Bogardus, School History of the United States, p. 384; Hart, Nere American History, p. 608. 
In discussing the World War, no authors adopt the revisionist point of view regarding the war guilt. The nearness of the event to the present, moreover, doubtless colors the treatment in such a way that Germany appears designing, crafty, cruel, militaristic, egotistical, and totally regardless of the rights of other nations. Many books deal with her imperialism and dream of world-empire, her idea of race superiority, her militarism, the disregard of international law culminating in such incidents as the Lusitania affair, and her alleged "atrocities." Few treat of the hidden forces making of Europe an armed camp before 1914.

In the half century that followed the Franco-Prussian War, the German people patiently endured the burden of immense standing armies and the expenditures for a greater navy [declares Guitteau]. They accepted this situation because they had been carefully educated to look upon war as something inevitable, as necessary to the future greatness of Germany. The schools throughout the empire distorted the facts of history and geography to teach the children of Germany that France was a nation of weaklings, Russia a nation of slaves; that most of the peoples of Europe were descended from Germans, and should be united within the empire; and finally that Germany must have larger boundaries, a result which could only be accomplished by a victorious war..... "Might makes right," said the German militarist, "and the dispute as to what is right is to be decided by war." Along with this doctrine that might makes right, that war is "a beautiful and holy thing," the Germans were taught . . . . that the German race is a race of superior beings as compared with other peoples; that its civilization (Kultur) is superior to all other civilizations; and hence it is the duty of Germany to civilize and Germanize the world $! . .$. It is not strange that this people, feeling themselves to be superior beings, came to believe that Germany did not possess the colonies, the commerce, and the influence which such a superior nation ought to have. ${ }^{20}$

It is worth while to continue the quotation from this author:

Inspired by these ideals, the military party which ruled Germany had for many years planned an aggressive war which should give Germany her place as the foremost world power. Not content with the provinces of Alsace-Lorraine which she had wrested from France

${ }^{20}$ Guitteau, Our United States, pp. 570-71. 
in 1871, Germany planned in this new war to steal the northeastern portion of France and to annex the whole of Belgium. This would give her immense fields of coal and iron ore, so necessary for industry, and especially for the manufacture of armaments, while the seizure of the Channel ports would enable her to hold a dagger at the heart of England. For Britain, with her world empire, was the enemy which Germany expected to attack eventually, although she hoped that this would be in a later war after France and Russia were crushed..... And after Britain, then America, peace-loving, idealistic, defenseless America, might be taken in hand, and taught her proper and subordinate place in a world ruled by German power..... This ambitious program was not the dream of a few German visionaries or jingoes. It was an actual plan, carefully worked out in detail by the war-mad clique which ruled Germany. The German people, it is true, were not consulted in the matter; there was no need to consult them, for Germany was ruled not by her people, but by the Kaiser supported by the military leaders and the Prussian aristocracy. So audacious and so insolent is this German plan of world power that it startles our belief; yet in the fateful year of 1914 it came near to realization..... Only the heroic resistance of the little Belgian army, the defeat of the German hordes by France in the battle of the Marne, and England's unbroken power on the sea, prevented Germany's dream of world empire from becoming an accomplished fact. $^{21}$

Evans' textbook is taken as typical of the greater number of histories and the quotations presented may be considered as representative.

In explaining the background of the war, there is emphasized the "wrong done to France" in the taking of Alsace-Lorraine by Germany, the lack of liberalism in Germany's government and the power of the upper classes, her militarism, her desire for more territory and greater trade, her hatred of England, the Berlinto-Bagdad Railway, her desire to Germanize the world, and to spread abroad German Kultur. ${ }^{22}$ "The increasing military preparations of Germany," the other nations regarded "with much distrust," as it compelled them "to sustain armies and navies in ever growing proportion and expense, until for many years there

${ }^{21}$ Ibid., pp. 571-73.

${ }^{22}$ Evans, op. cit., pp. 486-89. 
was a heavy burden of taxation, a feverish haste of armament, and a spirit of oppressive militarism that boded ill for the world." The summary of causes for the World War is here reproduced, since it sets forth the reasons ascribed by most of our textbook writers :

The world at large has laid upon Germany the charge of preparing for and precipitating the World War. The charges against that nation are:

1. Forty years of preparation in creating tremendous armaments and collecting vast supplies.

2. Justification and glorification of war on the part of her statesmen, writers, orators, and teachers.

3. Formation of the Triple Alliance, as a league of defense in case of attack by an outside nation.

4. Hostility to any purpose of the Hague Conference to limit armaments and to prevent war.

5. The expressed determination of Germany to gain more territory, dominate Middle Europe, and control the commerce of the world. ${ }^{23}$

Garner and Henson, Bourne and Benton, Stephenson, Thompson, Halleck, Robbins, Muzzey, Burnham, and Barnes offer typical treatments and follow in general the foregoing quotations. ${ }^{24}$

In these discussions Germany is described as "a despotic colossus bent on destroying free government throughout the world" $; 25$ a nation making war "the holiest and noblest human activity" ; ${ }^{26}$ a country who had "robbed" Denmark of her rich provinces of Schleswig and Holstein, who "tore" Alsace and Lorraine from France, and had made "war her glory and ambition her desire."27 One author points out how "in former times

${ }^{23}$ Ibid., p. 490.

${ }^{24}$ Garner and Henson, op. cit., pp. 590 ff.; Bourne and Benton, History of the United States, pp. 498 ff.; Stephenson, op. cit., pp. 442 ff.; Thompson, First Book in United States History, pp. 386-89; Halleck, op. cit., pp. 501 ff.; Robbins, School History of the American People, pp. 496-98; Muzzey, op. cit., pp. 497 ff.; Burnham, op. cit., pp. 573 ff.; Barnes, American History for Grammar Grades, pp. 397 ff.

${ }^{25}$ Stephenson, op. cit., p. $443 . \quad{ }^{26}$ Halleck, op. cit., p. 501.

${ }^{27}$ Thwaites and Kendall, op. cit., p. 511. 
Germans were admired for their work in science, philosophy, literature, and music," but how "success in industry and commerce" made them "regard as the highest aim the accumulation of material riches." 28 In the conduct of the war they are charged with "deliberately" adding to the "horrors" of war, of carrying "frightfulness into warfare on the sea, where fighting, terrible as it might be, had always been done with knightly courage and noble courtesy." 29

"Because of this return to the savagery of the barbarians from whom she sprang, by the end of 1916 Germany had forfeited the respect of every civilized nation, and henceforth the war became a crusade to rid the world of her militarism," is the assertion of Garner and Henson. ${ }^{30}$

The introduction of "huge new guns and high explosives," the use of poison gas in April, 1915, added "a new horror in warfare."31 German perfidy and cruelty were likewise demonstrated in the invasion of Belgium, whose neutrality "had been guaranteed by a solemn treaty signed by the great powers of Europe, Germany included." In their invasion of Belgium the Germans called this treaty "a scrap of paper," and spread "desolation and destruction on every hand." The "superb and inspiring resistance" offered by the Belgians "angered" the Germans to such a degree that "they wreaked a terrible vengeance," frightening the Belgians into submission by "a systematic policy of "frightfulness." " They brought "suffering, starvation and death" to "innocent victims, to women and children as well as to men." ${ }^{22}$

${ }^{28}$ Thompson, History of the People of the United States, pp. 469-70.

${ }^{29}$ Bourne and Benton, History of the United States, p. 509.

${ }^{30}$ Garner and Henson, op. cit., p. 629.

${ }^{31}$ West, op. cit., p. 709; Evans, op. cit., p. 500.

${ }^{32}$ Woodburn and Moran, Elementary American History and Government, pp. 443-44. The invasion of Belgium is uniformly criticized. See, as typical, McLaughlin, op. cit., p. 506; Forman, op. cit., p. 577; Stephenson, op. cit., p. 434; Eggleston, First Book in American History, pp. 209-10; Beard and Bagley, op. cit., p. 616; Thompson, History of the People of the United States, pp. $486-87$. 
It was this "brutal invasion of Belgium" which brought England into the struggle, declares West:

Germany had been certain that "shop-keeping" England would not fight. This was her first fatal blunder. And the consciousness that she had blundered called out, not a just contempt for her own government and its spies, who had mastered her, but a frenzy of hate for England-whose overthrow in a later war, she now openly declared, had been her goal all along. ${ }^{33}$

Germany's faults shine all the more brightly in contrast with the virtues of Belgium, whose "brave" and "devoted" army held in check the Kaiser's "ruthless invaders."34 The "heroic" French, too, "skillfully against overwhelming odds," with the help of England's "eager volunteers," saved "Western freedom and civilization . . . from a towering despotism."35

Thus "this terrible world-war, especially on the west front, was waged in terrible ways new to the world." For the Germans pursued a "policy of Frightfulness (Schrecklichkeit) deliberately adopted by the German government." The reader is then told :

Official authority in Germany for this policy dates from 1900. In that year a force of German soldiers set out to join forces from other European countries and from the United States in restoring order in China, after the massacre of Europeans there in the Boxer Rebellion. July 27 the Kaiser bade his troops farewell at Bremerhaven in a set address. In the course of that brutal speech he commanded them:

"Show no mercy! Take no prisoners! As the Huns made a name for themselves which is still mighty in tradition, so may you by your deeds so fix the name of German in China that no Chinese shall ever again dare to look at a German askance. .... Open the way for Kultur.,936

${ }^{33}$ West, op. cit., pp. 707-8.

${ }^{34}$ Evans, op. cit., p. 494; West, op. cit., p. 708; Burnham, op. cit., p. 575.

${ }^{35}$ West, op. cit., p. 708.

${ }^{36} \mathrm{~A}$ footnote at this point injects the statement, "The Germans made a number of savage 'punitive expeditions' for booty and rapine. In these they indulged not merely in indiscriminate murder of non-combatants, but even in many indescribable outrages upon women." The footnote adds that these outrages were stopped at the insistence of the American commander (ibid., p. 710). 
Now this Hun policy was put into effect in Western Europe. Never since the ancient blood-spattered Assyrian monarchs stood exultingly on pyramids of mangled corpses had the world seen so huge a crime. Belgium and northeastern France were devastated. Whole villages of innocent non-combatants were wiped out-men, women, children-burned in their houses or shot and bayoneted if they crept forth. All this by deliberate order of the "high command," and not to gain any military advantage, but, like the frightfulness of the old Assyrians, to terrify neighboring peoples-Dutch, Danes, Swiss-so that they might not dare risk a like fate.

About all this there is absolutely no doubt. Of course the German soldiery became brutalized, so that, with or without orders they committed thousands of nameless outrages upon women and Sioux-Indian mutilations upon captives. In like fashion, too, zeppelins raided England, partly to destroy military depots, but chiefly to drop bombs upon resident parts of London and upon peaceful villages. . . . .

So, too, the Germans deliberately bombed hospitals and Red Cross trains, murdering not only wounded soldiers but also the doctors and nurses. And soon the German submarine began to torpedo hospital ships, clearly marked as such. Nor is it easy to find any imaginable crime against the war customs of all civilized nations that was not committed and boasted of by Germany within a few months after this war began. ${ }^{37}$

Following discussions of America's effort to be neutral, come those telling of German spies and agents in the United States, the Zimmerman note, and the difficulties rising out of the submarine policy-a policy characterized as "barbarous" filled with "frightfulness," ${ }^{39}$ but upheld by Germany to the degree that "medals were struck to commemorate" the torpedoing of the Lusitania. ${ }^{40}$ These violations of neutrality and the invasion of Belgium led people "to see that the nation responsible for what was happening there could not possibly be right." ${ }^{41}$ Because of these things, "the spirit of justice" led us to embark upon a "great

${ }^{37}$ Ibid., pp. 710-11. The copyright of this book is 1918. Therefore, it is plain that it is a product of the war period.

${ }^{38}$ Ibid., p. 714.

${ }^{39}$ Guitteau, History of the United States, p. 605.

${ }^{40}$ Woodburn and Moran, op. cit., p. 451.

${ }^{41}$ Thwaites and Kendall, op. cit., p. 513. 
American Crusade," for in it "we were truly battling for the cause of humanity." A2 A "love of fair play" had developed in the American people "sympathy for the Allies which Germany and Austria found so hard to understand,"43 and we had come "to believe with the English and the French that Germany was aiming at world-dominion, as Assyria and Rome had done in the past." "44 Thus were we driven into war. ${ }^{45}$

In the active participation on the battlefield, throughout, the American forces did their share. For example, in the battle of the Argonne, they "carried on" despite "terrible slaughter."

They scarcely even hoped to come out alive; yet they fought onward with unyielding courage, unbroken devotion, till they captured the entire region of the Argonne..... Beyond the Argonne, our troops pushed on with swifter success, until they reached and controlled the main railroad by which Germany carried supplies to her foremost lines..... On November 6, our men's desperate advance brought them at last upon the heights above the city of Sedan..... The whole German army was retreating across the frontier into Belgium and Germany, beaten back from its prey by American arms. That was a great day for our unwarlike nation. ${ }^{46}$

Thus the Americans had a share in "democracy's victory." "47 Indeed, "our soldiers had fought gallantly, and had made possible the victory in the most stupendous conflict of history," for "we stood forth as no feeble foe to match even the terrible German colossus."49

As the preceding narrative will clearly prove, few books used in our schools can be charged with pro-Germanism. Even Long, in his America, and Bourne and Benton, in their recent American History, who are among the few who explain that "the causes of the Great War were not new but old, not one but many," "50 make

42 Horne, op. cit., II, 415.

44 Elson, op. cit., p. 521.

${ }^{4}$ Long, op. cit., p. 486.

${ }^{45}$ Gordy, op. cit., p. 503.

${ }^{46}$ Horne, op. cit., II, 435-37.

${ }^{47}$ Guitteau, Our United States, p. 617.

${ }^{48}$ Guitteau, History of the United States, p. 633.

" Horne, op. cit., II, 422.

${ }^{50}$ The statement of Long, op. cit., p. 482. 
the German military leaders responsible for the war. As the pupil reads the textbooks found most frequently in the schools, he cannot help feeling as one author puts it, "Thus did Germany commit the greatest crime of modern times, to the indignation and astonishment of the entire world."51

${ }^{51}$ Evans, op. cit., p. 493. In reality the quotation applies to the invasion of Belgium. In order to make clear the position of Long as to war guilt, the following quotation is given:

"German military leaders are blamed for the war, and their guilt is plain; but it should be remembered that other nations than Germany, aiming to dominate Europe by force, had all alike waged wars of conquest; that the diplomacy which governed their relations was a maze of trickery, double dealing, wickedness and folly; that all their frontiers bristled with guns; that the whole continent was like a number of military camps, watchful and suspicious, in which a slight difference might at any moment lead to clash of arms.

"Inevitably, therefore, the causes of the Great War were not new but old, not one but many. It was started by Austria-Hungary; but behind it were national jealousies and hatreds, bitter memories, selfish ambitions, greed of colonies, lust of power,-a host of evil conditions that do not affect America and that our people cannot by experience understand" (Long, op. cit., p. 482). 


\section{CHAPTER V}

\section{THE RELATION OF THE UNITED STATES TO COUN- TRIES OF THE WESTERN HEMISPHERE}

\section{CANADA}

Little space is devoted to the relations of the United States and Canada in our school histories. This lack of attention may be due to the friendly contacts which have existed for the greater part of our history. One can arrive at this conclusion easily when he considers that those nations to whom the thoughts of readers of textbooks are directed most often are those nations with whom the United States has at some time been at war, or with whom diplomatic controversies have arisen.

"Our relations with Canada have always been friendly but might well have been more intimate," is the view of Woodburn and Moran, in their Elementary American History and Government. "We have racial and geographical interests in common and it seems a pity in some respects that the reciprocity treaties failed of ratification."1 This excerpt will show the character of discussions when there are any relating to Canadian-American relations, aside from those treated in the section devoted to England. It may not be inappropriate at this point to recall statements in some of the textbooks relative to the friendly relations which have persisted between the two peoples, mentioned previously. $^{2}$ Typical of these is the following from Elson's United States: Its Past and Present: "Yet for a hundred years the two nations, without a fortress or a soldier or a warship have developed side by side in the most friendly relations. Why should not other nations learn a lesson from this?"3

${ }^{1}$ Woodburn and Moran, Elementary American History and Government, p. 515.

${ }^{2}$ See, for example, p. 41.

${ }^{3}$ Elson, United States: Its Past and Present, p. 289. 


\section{MEXICO}

Turning to the nearest neighbor at the south, the reader of textbooks will find a different attitude than that taken toward Canada. Because American arms have been successful there, because our relationship with Mexico has included far more international discord than with Canada, and because of the character of the people, the pupil will glean from his textbooks many facts pregnant with dislike.

The treatment of intercourse between the United States and Mexico is not uniform in the histories most commonly used. This is particularly true of discussions pertaining to the Mexican War. West, for example, characterizes the war as "unjust,"4 whereas Muzzey takes the opposite view, declaring that "Mexico had insulted our flag, plundered our commerce, imprisoned our citizens, lied to our representatives, and spurned our envoys," and that, as early as 1837, President Jackson had said that Mexico's offenses "would justify in the eyes of all nations immediate war."5

Thus, authors of textbooks can be said to be divided into two schools of thought exemplified by these scholars. Few historians put the matter as do McLaughlin and Van Tyne, in A History of the United States for Schools:

There is still room for question as to whether we were right in fighting Mexico, and scholars differ. Our patience was sorely tried, but a little fairness, a little more patience, and a little more generosity might have made war unnecessary. Polk's method of blaming Mexico reminds one of a soldier who came into camp with a dead sheep over

'West, History of the American People, pp. 517-18. See, for a similar point of view, Barnes, Short American History for Grades; Fite, History of the United States; Thwaites and Kendall, A History of the United States; Franciscan Sisters of the Perpetual Adoration, $A$ History of the United States; Hart, Nere American History; Channing, A Students' History of the United States.

'Muzzey, An American History, pp. 279-80. See also Bourne and Benton, American History; Long, America; Mace and Bogardus, History of the United States. In the case of the last textbook, the war is not condoned but it is not condemned, nor is the opposition argument to the war presented. 
his shoulder, though foraging was forbidden. "No sheep can bite me and live," he said. ${ }^{6}$

Similar in spirit to the McLaughlin and Van Tyne discussion is the middle ground taken by Beard, Woodburn and Moran, Stephenson, and Hulbert. By these historians both sides of the question are given in order that the pupil may draw his own conclusion. In addition to other facts commonly presented, Guitteau traces the strained relations which for some time had existed between the two countries prior to the outbreak of the war, declaring that "war might not have resulted if other differences between the two countries had not existed." This author explains to the reader:

American citizens living in Mexico had suffered enormous losses as a result of the frequent revolutions and chaotic conditions there; and for twenty years our government vainly sought reparation. . . . . Mexico [on the other hand] charged the United States with repeated violations of neutrality during the Texan revolution, and she persistently refused to recognize the independence of Texas, even nine years after the event. Meantime Texas had been recognized as an independent nation by the United States and by the leading nations of Europe. The independence of Texas was an accomplished fact, and Mexico's claim to her former province had nothing to rest upon. The reason why Texas was not annexed at an earlier date was not diplomatic, but political; it was due to the institution of slavery and to Northern opposition to the acquisition of more slave territory. ${ }^{7}$

The pupil reading different textbooks would find a difference of opinions among authors as to the cause of the war. Whereas Bourne and Benton, for example, declare that "annexation alone would probably not have brought on a war with Mexico," Vollentine asserts that annexation was the cause of the war. ${ }^{8}$ Long, in his America, however, presents the question of the real boundary thus:

The United States had fair claim to Texas as a part of Louisi-

- McLaughlin and Van Tyne, A History of the United States for Schools, p. 323, footnote.

'Guitteau, History of the United States, p. 348.

${ }^{8}$ Bourne and Benton, History of the United States, p. 315; Vollentine, The Making of America, p. 219. 
ana; but statesmen knew little about the region when to soothe Spanish feeling after the Florida trouble, they allowed Spain to fix the Sabine River as the western limit of the great territory, despite old maps which showed the Rio Grande as the boundary. ${ }^{9}$

In the actual combats between the Americans and Mexicans, the former are said to have "won every battle"10 in "the short war [in which] our countrymen displayed striking qualities."11 To Taylor, familiarly known as "Old Rough and Ready," who with "only two thousand troops" was able to drive "the much more numerous enemy" to retreat and [to] capture several cities," are attributed "brilliant" victories. ${ }^{13}$ Fish, in his History of America, however, declares that "our regular army was very small, and the volunteers who flocked to the flag were ill-trained, and suffered from the change of climate."14

From the discussions of events during and prior to the war, readers of the textbooks will gather the impression that the Mexicans were not only untrustworthy but cruel. The story of the Alamo alone would establish this opinion.

Santa Anna, the new Mexican president, a man of perfidious and cruel character, led an army in person to punish the rebellious province [states Muzzey]. His march was marked with terrible atrocities. At the Alamo, a mission building in San Antonio, a garrison of 166 Texans was absolutely exterminated, even to the sick in the hospital ward; and a little further on, at Goliad the defenders were massacred in cold blood after their surrender. ${ }^{15}$

On the other hand, according to Long, Santa Anna was "generously set free" by the Americans after being captured by the Americans. "Had he been shot for the Alamo massacre and

'Long, op. cit., p. 313.

${ }^{10}$ Halleck, History of Our Country, p. 330.

${ }^{11}$ McLaughlin and Van Tyne, op. cit., p. 323. See also Mace and Bogardus, op. cit., p. 268.

${ }^{12}$ Stephenson, A School History of the United States, p. 298.

${ }^{13}$ Horne, The Story of Our American People, II, 178.

${ }^{14}$ Fish, History of America, 296.

${ }^{15}$ Muzzey, op. cit., p. 269. Cruelty is attributed to Mexicans in other discussions either directly or by inference. See, for instance, White, Beginner's History of the United States, pp. 191-92. 
other barbarities, as he deserved, it would have spared Mexico and the United States much trouble," concludes this author. ${ }^{16}$

Lack of honesty, too, is attributed to the Mexicans by some writers, for "the Mexican border was a nest of bandits, who raided American settlements, stole cattle, killed men and women." ${ }^{17}$

In the diplomatic relations which the United States had had, the reader is told by Hulbert,

Mexico-running true to form-had been insultingly slow in settling claims due for the destruction of American lives and property. . . . . Most of these differences ought to have been straightened out by diplomacy, but a century's experience has taught us that Mexicans are difficult to deal with: ${ }^{18}$

Attention, however, should be called to the statements in two histories, which do not paint the Mexicans as the meanest of villains and the most despicable of foes. West, in his History of the American People, at one place speaks of them as "both brave and subtle," and McCarthy, in his history, asserts that during the storming of Chapultepec, "Mexican cadets of fourteen years shared the horrors of war with the coolness of men."19

The next contact of significance for this study, as chronicled by the authors of history textbooks, is with the Mexicans in Wilson's administration. It was during this unsettled period of Mexican history that the textbooks tell of "much bloodshed.", In this "turmoil many Americans living in Mexico were killed and their property destroyed." 21 In "the spring of 1914," it is

${ }^{16}$ Long, op. cit., p. 315. ${ }^{17}$ Ibid., p. 321.

${ }^{18}$ Hulbert, United States History, p. 287.

${ }^{19}$ West, op. cit., p. 518; McCarthy, History of the United States for Catholic Schools, p. 321.

${ }^{20}$ Forman, Advanced American History, p. 576. Several histories merely state conditions without using colorful language. See, for instance, Thompson, History of the People of the United States, p. 466; Mace, School History of the United States, p. 471.

${ }^{21}$ Ibid. See also discussions in Beard, History of the United States, pp. 594-96; Hulbert, op. cit., pp. 513-14; Gordy, History of the United States, pp. 452-53. Channing and McLaughlin in their textbooks omit this topic. 
frequently narrated, "several sailors belonging to our navy were arrested by the followers of Huerta and were roughly treated." It is further recorded that, in 1916, Villa, with "a band of outlaws," invaded New Mexico and "killed nine American citizens." Due to this act, a punitive expedition was sent by the United States to punish Villa, but it "accomplished but little.",22

In this land of "anarchy," "a ruthless, dissipated, revolutionary general, with Indian blood in his veins, fought his way to power-Victoriano Huerta, the reputed murderer of Madero."23 On April 9, 1914, sailors from an American ship landed at Tampico and were "seized" and carried off "to jail amid the hoots and jeers of the crowd," the reader of Muzzey's An American History discovers. When a formal salute to the flag was asked for as an apology for "this insult," this author observes that Huerta refused to comply As a result, Congress was asked by President Wilson for permission to use force in order to "maintain the dignity and authority of the United States." Following this, the pupil is informed of the loss of seventeen lives of the American marines sent to Mexico. ${ }^{24}$

The part of Germany in Mexican affairs at this time is mentioned by some authors, one writer asserting that "the German government had bribed the Mexican revolutionists to attack the lives and property of our citizens in Mexico and along the border," and that "by involving the United States in a war with Mexico, the German government believed that our nation would be less able to defend itself against German outrages on the high seas."25

${ }^{22}$ Ibid., pp. 576-77. See also Muzzey, op. cit., p. 494; McCarthy, History of the United States, pp. 459-60; Horne, op. cit., II, 398-401.

${ }^{23}$ Muzzey, op. cit., p. 493.

${ }^{24}$ Ibid., p. 494. See also Robbins, School History of the American People, pp. 482-83; Hall, Smither, and Ousley, $A$ History of the United States, pp. 458-60; Garner and Henson, Our Country's History, pp. 603-5.

${ }^{25}$ Guitteau, Our United States, p. 552. See also Mace and Bogardus, op. cit., p. 464; Leonard and Jacobs, The Nation's History, p. 522; O'Hara, $A$ History of the United States, p. 402. 
The recent desire of some Americans for war with Mexico to satisfy American claims is mentioned by Beard. ${ }^{26}$

SOUTH AMERICA

The contacts of the United States and the countries of South America are not only those which arise usually between neighboring nations, but they also embrace the results of the Monroe Doctrine. The Doctrine is discussed elsewhere as a part of our foreign policy. In this section it will not be dealt with primarily as a phase of the foreign policy of the United States as related to European powers, but as directly affecting South American political life.

Described as effectually guarding "the gateway of the Western World for more than a hundred years,"27 the Monroe Doctrine, in general, appears the means of a protection afforded our southern neighbors. "The immediate effect [of the pronouncement]," according to Mace and Bogardus, "was to keep the peace. . . . . With the exception of Maximilian in Mexico, the Monroe Doctrine has kept out foreign nations and has given the nations to the south of us time to get on their feet." 28 Indeed, as a doctrine "really intended for the protection of the weaker states," it has made the United States a benefactor of those states. ${ }^{29}$ As Horne, in The Story of Our American People, puts it, "Much as the Latin Americans sometimes blame our people for having seized northern Mexico or Panama, or overridden them in other ways, we have clearly been a large factor in saving them from European conquest." 30 Moreover, as the preservative of the spirit of liberty, the Monroe Doctrine has served, according to one historian, to demonstrate that "peculiar sympathy" which North America had for those "Spanish-American patriots fighting to make good their own independence."

The "resentment" alleged to exist in the hearts of South Americans toward the people of the United States is not unnoted

${ }^{28}$ Beard, op. cit., p. 625. ${ }^{2 \pi}$ Elson, op. cit., p. 298.

${ }^{28}$ Mace and Bogardus, op. cit., p. 223.

${ }^{29}$ Hart, School History of the United States, p. 454.

${ }^{30}$ Horne, op. cit., II, 287.

${ }^{31}$ Fite, op. cit., pp. 255-56. 
by writers of textbooks. The protection which the United States has given their countries is said by some writers to be the cause. It is accounted a perplexing and difficult bit of diplomacy in "awarding protection to South America" to "avoid wounding the pride of the younger nations, especially of the three powers of Argentine, Brazil, and Chile, the 'A. B. C.' powers of South America. .... ",32

The Panama revolt is likewise held to have "caused serious ill-will through all South America."

Roosevelt had highly pleased our Latin neighbors of the south by his defense of Venezuela. Now, his defiance of Colombia made them feel again, as in Mexico's case, that we were a bullying race, ready to snatch anything we wanted from the weak. They gave little heed to our plea that Colombia's renewed demand, after her rights had already been paid for by France wronged both the United States and Panama. ${ }^{33}$

Thus, many South Americans came to distrust us; and "our successive Presidents all tried to restore harmony by satisfying Colombia," a gesture worth while because of "the good will we thus won from Colombia and from all South America."34

As another instance of hostility toward the United States, the Chilean episode in Harrison's administration is discussed, for, as McLaughlin puts it, the people of Chile "cherished resentment against Americans."

Withal, the frequent meetings of Pan-American congresses and the formation of the Pan-American Union are deemed evidences of amity on the part of both continents. Characterized by Fite as "one of the finest signs of the times in the diplomacy of the twentieth century," Pan-American congresses are said to be promoting the "spirit of brotherhood among the independent American republics." ${ }^{36}$ As a further token of increasing good will there is presented the instance of the mediation of the A B C powers

${ }^{32}$ Ibid., p. 525.

${ }^{33}$ Horne, op. cit., II, 375.

${ }^{34}$ Ibid., p. 467.

${ }^{25}$ McLaughlin, History of the American Nation, p. 499.

${ }^{36}$ Fite, The United States, p. 406. 
in Mexican-American relations in the second decade of the present century. ${ }^{37}$

The increasing trade between North and South America is considered an advantage to both. Special pleas for a continuation and extension of trade and credits are voiced by some writers including Guitteau, Woodburn and Moran, Bourne and Benton. "W8 "We must know more of the people, industries, resources, and trade of the Latin-American republics to the south of us," declare Woodburn and Moran. "We have neglected them somewhat in the past. We are not so likely to do so in the future. We have vast interests in common with them. Pan-Americanism is a growing idea."39

${ }^{3 \pi}$ Ibid., p. 411.

${ }^{38}$ Guitteau, Our United States, pp. 633-34; Bourne and Benton, American History, pp. 670-71.

${ }^{39}$ Woodburn and Moran, op. cit., p. 514. 


\section{CHAPTER VI}

\section{RUSSIA IN UNITED STATES HISTORY TEXTBOOKS}

Very little attention is devoted to Russian-American relations in the study of American history, if one judge by the space allotment in those textbooks examined. The first instance of contacts chronicled by the histories is the warning issued Russia in the pronouncement of the Monroe Doctrine, for "Russia was attempting to extend its power on the Pacific coast south from Alaska as far as the fifty-first parallel, over a part of the territory already claimed by both Great Britain and the United States."1

During the Civil War, the attitude of Russia in contradistinction to that of England and France is said by one author to be "the pleasantest feature of our foreign relations." The motives leading Czar Alexander to warn this country that " $\mathrm{Na}$ poleon was conspiring with the British and Spanish governments to interfere in our war" are attributed to an interest in America's problem of negro slavery and the enmity of Russia toward France and England.

Whether this timely show of friendliness [the appearance of a Russian fleet in New York Harbor] was accidental or purposeful was long debated on both sides of the ocean. It appears now that the "demonstration" was planned as a hint that, if France or Britain interfered in American affairs, they might have an enemy at their backs. It appears also that America paid (so far as gold can pay for anything more precious than gold) by adding the expenses of the fleet to the purchase price of Alaska. ${ }^{2}$

${ }^{1}$ Fite, History of the United States, p. 257. See also Forman, Advanced American History, pp. 257-58; Bourne and Benton, American History, p. 271; Halleck, History of Our Country, p. 276; Thompson, $A$ History of the People of the United States, p. 253; Thwaites and Kendall, A History of the United States, p. 250.

${ }^{2}$ Long, America, p. 384. 
Other authors speak of Russia in amicable terms. "Our good friend Russia,"3 "a stanch friend of the federal government,"4 a country having "a friendly disposition" toward the United States, ${ }^{5}$ and "extremely friendly" to "the cause of the Union." Not all textbooks mention the attitude of Russia toward the North. ${ }^{7}$

The czar of Russia as the instigator of the Hague Conference is mentioned in some of our textbooks. ${ }^{8}$ Such a laudable move, however, is counterbalanced by the later descriptions of some writers of Russia's defection in the World War, when Lenine and Trotsky as "false leaders completed the betrayal of their country by the shameful treaty of Brest-Litovsk. . . . " Owing to Russia's surrender, it is said, Rumania was left "in a helpless position, surrounded by hostile powers."10

On coming into power in Russia [declares Guitteau], the Bolsheviki, or extreme socialists, inaugurated a rule of violence and bloodshed. They abolished the most primitive forms of justice, and thousands of persons suspected of being unfriendly to Bolshevism were shot or hanged without the semblance of a trial. Every newspaper which did not favor the cause was suppressed; and the Constituent Assembly, an anti-Bolshevist body elected by the Russian people, was forcibly dissolved.

${ }^{3}$ Guitteau, Our United States, p. 481.

- Robbins, School History of the American People, p. 345.

- Garner and Henson, Our Country's History, p. 460.

' Hart, New American History, p. 493.

${ }^{7}$ McLaughlin, History of the American Nation; Evans, The Essential Facts of American History; Gordy, History of the United States; Woodburn and Moran, Elementary American History and Government, do not discuss this point.

${ }^{8}$ Guitteau, History of the United States, p. 584; Fish, History of 'America, p. 530; Muzzey, An American History, p. 478; McLaughlin, History of the American Nation, p. 530; Beard, History of the United States, p. 514; Fite, op. cit., p. 517; Lawler, Essentials of American History, p. 422; Hall, Smither, and Ousley, $A$ History of the United States, p. 442; Evans, op. cit., p. 489; McCarthy, History of the United States, p. 442; Mace and Bogardus, History of the United States, p. 382.

'Guitteau, Our United States, p. 596; Guitteau, History of the United States, p. 620. See also McLaughlin, op. cit., p. 580; Muzzey, op. cit., p. 520.

${ }^{10}$ Guitteau, History of the United States, p. 620. 
The Bolsheviki would not fight against the Germans, to whom they had surrendered one third of Russia's territory; but they were ready to fight and plunder their own countrymen. . . . . Hundreds of thousands of lives were lost from starvation and disease, so that in the end the Bolshevist tyranny cost Russia more lives than the war itself.

Not the least among the crimes of the Bolshevist leaders was their attempt to undermine the Governments of other countries, so as to bring on a universal revolution. To accomplish this they relied upon bomb outrages, the destruction of factories and material, and the stirring-up of class hatred..... An attempt was also made .... to undermine our own Government by the spread of Bolshevist doctrines in the United States. But the American Federation of Labor dealt a severe blow to the agitators when its national convention voted against the proposed general strike, and denounced the principles of Bolshevism. ${ }^{11}$

It will, therefore, be apparent that a reading of the textbooks will present Russia in a way to excite, on the whole, friendly sentiments before the opening of the World War. On the other hand, discussions dealing with Russia for the period since 1917 will doubtless arouse the opposite sentiments.

${ }^{11}$ Ibid., pp. 644-45. See also Hulbert, United States History, p. 564; Horne, The Story of Our American People, II, pp. 430-31; Mace, School History of the United States, p. 494. 


\section{CHAPTER VII}

\section{COUNTRIES OF THE FAR EAST IN AMERICAN HISTORIES}

\section{CHINA}

In 1917, Timothy T. Lew published an investigation of textbooks in history in common use in the American public schools, in order to determine to what extent Chinese-American relations were treated. His findings led him to conclude that, owing to the little attention given to this subject, indifference and prejudice might result. He further held that many events which might show cordial relations between the two nations did not appear in the books. He said:

While the initiative, planning, constructive skill, - the brain power -as well as the financing, that has been devoted to the marvelous industrial development and westward expansion of the United States has been supplied by Americans and Europeans, the Chinese have not been without a share in the great work. Less conspicuous, less valuable and seldom honored it has been; yet nevertheless the faithful, plodding toil of thousands of unskilled Chinese laborers has gone into the railroads, highways, mines, cities and farms that have marked the geometric progression of America's industrial development. . . . . Practically none of the authors whose textbooks we have examined give full credit to the contribution of Chinese labor in America. ${ }^{1}$

The same statement as to space allotment as to ChineseAmerican relations is true of those histories written since the World War. Taking, for example, ten of the most commonly used and most recently written or revised senior high school textbooks, the reader finds that topics relating to the two countries may be grouped under six heads: trade relations; the Boxer Rebellion and the Open Door; Chinese labor and restrictions upon Chinese immigration; China in the past, particularly during the

${ }^{1}$ Timothy T. Lew, "China in American School Text-Books," Special Supplement to Chinese Social and Political Science Reviere, VI-VII (July, 1923). 
period of discovery; consideration of China at the Washington Arms Conference; and the Six-Power Loan. No textbook, in those mentioned as illustrating the customary discussions, touches upon all the points enumerated. All treat the Boxer Rebellion and the Open Door Policy. All but one mention Chinese immigration and the attitude of the United States toward it. ${ }^{2}$ Only one introduces information regarding the Six-Power Loan. ${ }^{3}$ Four deal with trade relations between the two countries. ${ }^{4}$

Owing to economic conditions, the Chinese are pictured as. generally an undesirable element in the United States. This fact is explained as due to their influence in reducing wages and lowering the standard of living. "Accustomed to starvation wages and indifferent to the standards of living," says Beard, "they [the Chinese] threatened to cut the American standard to the point of subsistence." $" 5$

The first restrictive measures on Chinese entrance to this country are justified, therefore, on the ground of economic necessity. "Though the law seems harsh," declares Fite, "every nation undoubtedly possesses the right to expel from its shores any aliens whose presence may be considered dangerous to its interests, and likewise to refuse admission to all whom it may consider undesirable."6

Evasion of restriction, moreover, is charged against the Chinese by Evans, who places the blame at the door of the

${ }^{2}$ Hulbert, United States History. ${ }^{3}$ Muzzey, An American History.

- Fite, History of the United States; Fish, History of America; Guitteau, History of the United States; Beard, History of the United States. The histories taken as typical and to illustrate this condition were: Beard, op. cit.; Bourne and Benton, American History; Fish, op. cit.; Fite, op. cit.; Forman, Advanced American History; Guitteau, op. cit.; Hulbert, op. cit.; Latané, History of the United States; McLaughlin, History of the American Nation; Muzzey, op. cit.

${ }^{\circ}$ Beard, op. cit., p. 583. See, among others, Fite, op. cit., p. 458; Evans, The Essential Facts of American History, p. 428; Fite, The United States, pp. 453-54; Barnes, Short American History for Grades, p. 315; Barnes, American History for Grammar Grades, p. 344; Elson, United States: Its Past and Present, p. 468; Leonard and Jacobs, The Nation's History, p. 393.

' Fite, History of the United States, p. 458. 
"shrewd Oriental," who can land in Canada and "easily find his way across the border."

The part of the United States in the Boxer Rebellion is held a bright page in our history. The returning to the Chinese of part of the indemnity money and, as a result, the action of the Chinese government in sending native students to America to study is hailed as a most effective means of promoting international good will. The Open Door Policy is also described as springing from a spirit of generosity toward peoples weaker than ourselves. ${ }^{8}$

\section{JAPAN}

The benefit of Perry's visit to Japan does not pass unnoticed in most of our histories. "And from that day," declares Barnes in his Short American History for Grades, "Japan, copying American ideas and methods, has advanced until it is now the foremost nation of Asia." "Under the friendly guidance of the United States, she started her remarkable modern career," says Horne. "She rapidly developed her industries, and became the powerful country that she is today."10

The part of the United States in the Russo-Japanese War again shows this country in the rôle of benefactor to Japan. In a settlement characterized as "spectacular," a victory for the United States in its effort to protect the smaller nation.

${ }^{7}$ Evans, op. cit., p. 428.

${ }^{8}$ See Fite, History of the United States, p. 531; Fite, The United States, p. 412; Mace, School History of the United States, p. 458; Beard, op. cit., pp. 501-2; Barnes, Short American History for Grades, p. 333; Stephenson, A School History of the United States, p. 416; Garner and Henson, Our Country's History, pp. 537-38; Barnes, American History for Grammar Grades, pp. 352-53; Mace and Bogardus, History of the United States, p. 378; Leonard and Jacobs, op. cit., p. 490; Halleck, History of Our Country, p. 443; Gordy, History of the United States, pp. 437-38; Burnham, The Making of Our Country, p. 564; Forman, op. cit., pp. 529-30; Horne, The Story of Our American People, II, 362-63.

${ }^{9}$ Barnes, Short American History for Grades, p. 226.

${ }^{10}$ Horne, op. cit., II, 203.

${ }^{11}$ Beard, op. cit., p. 512. 
As with China, immigration policies as they relate to the Japanese are condoned. "Were we to throw open our doors to unlimited Japanese immigration we should be inviting a far more serious race problem than we now have with the Negro and the Indian," $" 12$ declares one writer. Nor is attention focused upon the relations existing between the two countries since the last immigration law was enacted and discriminatory measures were directed toward Japan.

${ }^{12}$ Elson, op. cit., p. 468. 


\section{CHAPTER VIII}

\section{RACIAL ELEMENTS IN THE UNITED STATES}

THE DUTCH

Of those peoples with whom Americans have had contacts, not discussed elsewhere, the Dutch of Colonial times have received the least criticism. Their "usual fairness," their industrious habits, ${ }^{2}$ and their enterprise in trading ${ }^{3}$ are characteristics which are given special emphasis. In view of the small part they have had in our history, it is not strange that they receive little attention as compared with France, England, and Germany.

\section{THE SCOTCH AND IRISH}

Among the early immigrants to America mentioned in the histories are the Scotch-Irish, described by Muzzey as "that sterling, hardy race of men which has given us some of the most distinguished names in our history." "They were, says Forman, the best of pioneers, and they soon were out on the frontier, making settlements wherever they could find good vacant lands. They paid but little attention to the claims of the Indians, for they thought "it was against the laws of God and nature that so much good land should be idle while so many Christians wanted it to work and to raise their bread."

The loyalty of the Scotch-Irish to the Colonial cause is a further instance of commendation of their virtues. ${ }^{6}$

As a land of refuge and of opportunity, according to histories which treat in any detail of the immigration problem, America

${ }^{1}$ Horne, The Story of Our American People, I, 243.

'Muzzey, An American History, p. 59.

${ }^{3}$ Channing, A Students' History of the United States, p. 66.

${ }^{4}$ Muzzey, op. cit., p. 60.

${ }^{5}$ Forman, Advanced American History, p. 86. See also Mace and Bogardus, History of the United States, pp. 67-68; Hart, School History of the United States, p. 248.

'Bourne and Benton, American History, p. 103. 
appealed to the Irish, who flocked to this country during the Potato Famine. The loyalty of this group later to the Union cause in the Civil War is not forgotten in enumerating the peoples who answered Lincoln's call. ${ }^{\text {? }}$

However, little space is devoted to these peoples in most histories. To get a full account of Irish activities, the reader must turn to the textbooks prepared for Catholic schools, such as McCarthy's History of the United States. The following incident, for example, is not discussed in any but Catholic histories :

The wild summer of 1844-It was in 1844 that Bishop Kenrick, of Philadelphia, asked the school board to allow Catholic children to use the Catholic version of the Bible. Many were induced to believe that Catholics wished to prevent Protestant pupils from reading their own Bible. In American Protestant opinion, during this period of anti-Catholic feeling, any Catholic was sufficiently bad, but the Irish were odious. In a Native American meeting violent language was used against the members of that persecuted race. At night their houses were stoned and burned. A few attempted to defend their homes and thus some members of the mob were slain. Then was raised the cry, "To the nunnery!" At once a rush was made for a little community of Sisters of Charity, but a volley from its defenders drove the fanatics away for the moment.

On the next day, after the burning of twenty-nine dwellings of Irish Catholics, a church and parochial residence were set on fire. The firemen declined to serve, and the militia were mute. At another place the mayor, who came out to plead for order, was brutally silenced by a missile, which knocked him senseless. The police were dispersed. Amid the shouts of a frenzied mob St. Augustine's Church also was devoted to the flames. When its blazing cross fell, there went up a mighty roar. The house of the Sisters did not escape a second time. The heroines of the cholera scourge were bereft of home.

In this emergency Bishop Kenrick was compelled to suspend the exercises of public worship in the remaining Catholic churches. A grand jury called to inquire into the riots falsely ascribed them to "the efforts of a portion of the community to exclude the Bible from public schools." Those guilty of theft, arson, and murder were mentioned as "unoffending citizens." Though some ministers fanned

${ }^{7}$ Forman, op. cit., p. 378. 
the flames of hate, the more respectable Protestants of Philadelphia were ashamed of the atrocities. ${ }^{8}$

Another example of anti-Irish sentiment is narrated by the Franciscan Sisters of the Perpetual Adoration in their textbook:

From the beginning of the establishment of Catholicity in America, there existed a party called Nativists, which, under the pretext of defending American institutions, carried on a warfare, sometimes open and sometimes secret, against the Catholic Church. Although there had been no open sign of hostility against the Catholic Church for nearly a generation, unhappily, as time went on, its growth was regarded by the Nativists with disfavor. Vile books, sermons and lectures against the Catholic religion gradually gave rise to such excitement that a mob (August 11, 1834) attacked the Ursuline Convent at Charlestown, near Boston, drove out the defenseless nuns and children, and burned their home to the ground. St. Mary's Church in New York was also plundered and given to the flames. The government made no attempt to prevent these outrages and the leaders were subjected to only a farcical trial, which resulted in their acquittal. ${ }^{9}$

\section{THE PROBLEM OF IMMIGRATION}

The problem of immigration is presented from various points of view in our histories. Restriction, on the whole, is not condemned, and in many cases it is strongly indorsed. Immigrants from Northern Europe, or those coming before 1880, are usually described as desirable. In some instances, the immigrant of recent years is said to be undesirable.

Various motives are attributed to foreigners seeking homes in the New World, including the spiritual blessings of a free country and the economic advantages of free land, ${ }^{10}$ all of which are said to have been given freely to aliens, for "American democrats

${ }^{8}$ McCarthy, History of the United States for Catholic Schools, pp. 315-16.

${ }^{9}$ Franciscan Sisters of the Perpetual Adoration, $A$ History of the United States for Catholic Schools, p. 342.

${ }^{10}$ Gordy, History of the United States, p. 306. See also Fite, The United States, p. 455; Barnes, American History for Grammar Grades, pp. 266-67; West and West, The Story of Our Country, p. 356; Atkinson, European Beginnings of American History, p. 3; Thompson, First Book in United States History, p. 293; Thompson, History of the People of the United States, pp. 230-31. 
wanted to share their good fortune with the poor and oppressed in all parts of the world."11

On the other hand, some historians mention the contributions to American culture made by immigrants, particularly of Northern Europe. Referring to aliens, especially those from Germany who came to the United States before 1850, The Story of Our Country acknowledges their introduction of new customs and ideas to American social and intellectual life. "They brought. with them a deep love of music," it is said, "and had ideas for the development of schools and universities which were in advance of ours at that time."12 Material contributions "too large to estimate"13 are likewise attributed to them, their industrious habits and qualities of good citizenship making of them desirable elements in the up-building of their adopted country. Indeed, it is pointed out by one author:

These different kinds of people all had something to bring with them. . . . French and Swiss immigrants were skilled in vine growing; Irishmen know how to raise cattle; Germans were fond of music; the Swiss were builders of good roads. Most of the immigrants found work or made work, and the great West could not have been built up so quickly without the aid of the foreign-born laborers and their children. ${ }^{14}$

On the other hand, as pointed out in the discussion relating to the Chinese, the newer immigration does not receive much favorable comment.

Immigrants that come from the northern countries of Europe are of a class that make good citizens, and as long as most of the immigrants were of that class all went well [says Thompson]. But since the War of Secession most of the immigrants coming to this country have been from the lower classes of eastern and southeastern Europe, and they give much trouble. They are for the most part very ignorant, and having been downtrodden in their old homes, they have no respect

${ }^{11}$ Stephenson, A School History of the United States, p. 315.

${ }^{12}$ West, The Story of Our Country, p. 357.

${ }^{13}$ Gordy, op. cit., pp. 386-87. See also Thwaites and Kendall, $A$ History of the United States, p. 434.

${ }^{14}$ Hart, op. cit., p. 390. 
for law or government. In fact, many of them would like to see the government of the United States destroyed. How to deal with this undesirable class of immigrants is one of the most serious problems that we have today. ${ }^{15}$

Thus the problem of assimilating a diverse, "worthless and dangerous" people ${ }^{16}$ and making of them "good Americans" is presented to the pupil as one of no mean proportions. In instilling in them a love of the new homeland and "an adequate knowledge of American institutions and American government," teaching the English language is held essential. ${ }^{17}$ Lack of such training, we are told, is frequently responsible for political corruption and other vices charged against our recent newcomers. ${ }^{18}$ Although some writers commend the new immigration for "countless and invaluable" aid in American industrial growth, ${ }^{19}$ restrictive measures as to entrance are generally indorsed. ${ }^{20}$

In brief, as Fite puts it,

It is the duty of all who have come to America and are enjoying its privileges, to take out naturalization papers and become citizens. [For] this is their country, in which they do their work and bring up their families, and in which they expect to live and die. It is theirs for the opportunities it offers and the protection it affords, and it is theirs too in the obligation it places upon them to bear a share of its burdens. For old and new citizens to work together for the country's good, and to conserve the best that native and foreign born alike contribute to the national character, this is the true Americanism. ${ }^{21}$

${ }^{15}$ Thompson, First Book in United States History, p. 294. See also Leonard and Jacobs, The Nation's History, pp. 455-56.

${ }^{18}$ Burnham, The Making of Our Country, pp. 544-49. See also Barnes, Short American History for Grades, p. 380; Barnes, American History for Grammar Grades, p. 432; Gordy, op. cit., p. 537.

${ }^{17}$ Woodburn and Moran, Elementary American History and Government, pp. 513-14.

${ }^{18}$ See, for example, on this point Mace and Bogardus, op. cit., pp. 389-90.

${ }^{10}$ Beard and Bagley, History of the American People, pp. 502-5. See also Fite, op. cit., p. 453.

${ }^{20}$ Mace, School History of the United States, p. 494; Guitteau, Our United States, p. 514.

${ }^{21}$ Fite, op. cit., p. 456. 


\section{THE NEGRO}

The place of the negro in American life is not ignored by the writers of history textbooks, but more attention is paid to the negro as a slave than as a citizen of the present. Although the brighter side of plantation life is depicted by some authors, nevertheless the sympathy of the reader is aroused for a people held in a bondage characterized as a "barbarous system," of which there were "odious aspects." 22 The reader's compassion is quickened by the first narratives concerning slavery and its origin. ${ }^{23}$ In its later stages slavery is painted no less realistically, particularly by northern historians. According to Burnham,

Slavery was almost as great a curse to the white people of the South as it was to the negroes. It made the masters hard, passionate, and overbearing. White children who grew up with negro playmates learned much that was evil from them. Ignorant, unskilled, and unwilling slave labor retarded the industrial development of the slaveholding states, in which they were very backward when compared with the free states. ${ }^{24}$

A different impression might be gained were the pupil to read only some "southern" histories in which the condition of slaves is described as generally not hard upon a people most of whom were "content to remain as they had been born." 25 Yet the greater number of histories picture the institution of slavery as a "growing evil," 26 economically a poor system, ${ }^{27}$ and one in which the evils were greater than the benefits. ${ }^{28}$

In the consideration of the present-day negro problem, history textbooks do not have so much to say. In those books in which it is treated, far less space is devoted to it than to the negro problem before 1860. This is, of course, as one would expect.

${ }^{22}$ McLaughlin, History of the American Nation, p. 348.

${ }^{23}$ See, for example, Hart, Nere American History, p. 115; Muzzey, op. cit., p. 247; West and West, op. cit., p. 325.

${ }^{24}$ Burnham, op. cit., p. 344 .

${ }^{25}$ Evans, The Essential Facts of American History, pp. 349-50. See also Hall, Smither, and Ousley, A History of the United States, p. 267.

${ }^{26}$ Gordy, op. cit., p. 278. ${ }^{27}$ McLaughlin, op. cit., pp. 273-75.

${ }^{28}$ Burnham, op. cit., p. 548. 
But the negro is usually accorded praise for his economic progress from "abject poverty and the mental weakness of slavery" toward industrial independence. ${ }^{29}$ His great advance in education is pointed out by several authors, including books designed primarily for southern schools. Evans, in The Essential Facts of American History, for instance, makes clear that "they [negroes] have shown an exceeding eagerness for education, and are willing to endure hardships for the advantage to be derived from attending schools..... As a race they have become hard-working and orderly citizens."

In the forward movement of negro education, Booker T. Washington is given high praise by several authors. ${ }^{31}$ However, the greater number of textbook writers pass by unnoted, not only his services to his race, but negro education and progress in general. ${ }^{32}$

Although mentioning the services of Booker $\mathbf{T}$. Washington to his people, West and West, in The Story of Our Country, preface their remarks of commendation as to the progress of the negro with the statement that "the problem of the negro in the United States-his education, his rights, his relations to white men-is still unsolved."33 These authors also assert that leaders of both races have concluded that the white and black are better apart at present. ${ }^{34}$ As McLaughlin and Van Tyne put it: "It is coming more and more to be believed that white and black must be kept severed socially, and that the dominant race must see to it that the negro be given a helping hand toward educating him and making him useful in industry."35

${ }^{29}$ Long, America, pp. 398-99.

${ }^{30}$ Evans, op. cit., p. 420. See also Beard, History of the United States, pp. 397-98; Hart, School History of the United States, pp. 410-11; Elson, United States: Its Past and Present, p. 448; Gordy, op. cit., pp. 379-80.

${ }^{31}$ Bourne and Benton, op. cit., p. 566; Robbins, School History of the American People, pp. 456-57; Gordy, op. cit., p. 380.

${ }^{32}$ Mace and Bogardus, op. cit.; Channing, op. cit.; Forman, op. cit.; Muzzey, op. cit.; Guitteau, History of the United States; Hulbert, United States History; Fite, History of the United States, are among the number.

${ }^{33}$ West, op. cit., p. 405.

${ }^{34}$ Ibid., p. 406.

${ }^{35}$ McLaughlin and Van Tyne, A History of the United States for Schools, p. 442 . 
These authors, Beard, and others indicate that a political and social inequality exists in the South between the two races. Beard, however, points out that, with the migration of negroes to the North, the problem was no longer local but national. ${ }^{36}$ As a part of the problem, some authors attribute to the negro a tendency to be the prey of political corruption, ${ }^{37}$ and still in large numbers to be "ignorant, lazy and thriftless." 38

\section{THE INDIAN}

Characterized as "wild," "uncivilized," "cruel and barbarous by nature," ${ }^{39}$ the Indian of the day of our forefathers is often encompassed by "a lurid trail of fire and blood." 40 Withal a "vigorous and hardy people, well built, tall and handsome" and possessed of a "bitter hatred of enemies," the red man is sometimes, on the other hand, shown to be the victim of the greed of the white man to whom originally he was "generally friendly." Some authors strive for balance, indicating that the Indian sometimes contributed materially to the welfare of the colonists and that both races frequently failed "to comprehend the other's point of view."42

There is the same difference of opinion relative to our later policy toward the Indians. Guitteau describes it as "unjust," pointing out that the white men "constantly encroached upon the lands reserved for the Indians," thereby necessitating the tribe to move farther west..3 "For years," declares Robbins,

${ }^{36}$ Beard, op. cit., p. 398.

${ }^{37}$ See, for example, Burnham, op. cit., p. 548. This was said especially directly following the Civil War. See Gordy, op. cit., pp. 369-70; Mace and Bogardus, op. cit., pp. 336-37; Muzzey, op. cit., p. 389.

${ }^{38}$ Burnham, op. cit., p. 549. See also, for adverse criticism, Horne, op. cit., II, 298.

${ }^{39}$ Forman, op. cit., p. $58 . \quad{ }^{40}$ Burnham, op. cit., p. 47.

${ }^{41}$ Hart, New American History, pp. 14-15. See also Muzzey, op. cit., p. 25; Hulbert, op. cit., pp. 9-12; Fish, History of America, p. 82.

${ }^{42}$ James and Sanford, American History, p. 101. See also Rugg, The Social Science Pamphlets, I, No. 1, 107-8. The divergent points of view are reflected, for example, in Long, op. cit., and Hulbert, op. cit. The latter is sympathetic.

${ }^{43}$ Guitteau, Our United States, p. 494. 
"the policy of our government was to treat the Indian as if he were a child and a pauper." 44 The opposite point of view may be represented by Long, who characterizes the reservation policy toward the Indian as "liberal" and "generous."

Governmental policy since 1885 is universally indorsed. "Since that time," says Robbins, "there has been little serious trouble, and the Red Man is learning to take his place as a citizen, making his own living and paying his own taxes."46 Garner and Henson emphasize the fact that the new policy has tended to make the Indians good citizens. ${ }^{47}$

Even Long, whose general treatment is such that neither pity for the Indian nor admiration for his personal qualities will be kindled in the reader, concludes that

already he is making use of his farms, ranches and mineral lands. His young men proved gallant soldiers, brave and loyal, when they followed our flag overseas in the Great War, 1917-1918. The American people are now resolved that the Indian shall be treated not as a charity patient, a "ward of the nation," but as a man having equal right with other Americans to "life, liberty and the pursuit of happiness." 48

${ }^{44}$ Robbins, op. cit., p. 412.

${ }^{45}$ Long, op. cit., p. 410. See also Guitteau, Our United States, pp. 494-95.

${ }^{46}$ Robbins, op. cit., p. 412. See also Gordy, op. cit., pp. 390-91.

47 Garner and Henson, Our Country's History, pp. 488-89. See also Channing, op. cit., p. 542.

${ }^{48}$ Long, op. cit., p. 411. 


\section{CHAPTER IX}

\section{THE DEPENDENCIES OF THE UNITED STATES}

Judging from the evidence accumulated in history textbooks, those countries are indeed fortunate, not only in material, but in spiritual matters who fall under the jurisdiction and protection of the United States. Cuba, "pest-ridden" and rescued from "chaos" in three years, was given law, order, and cleanliness by American officials. "To the amazement of the world," after this brief period, American "troops were withdrawn leaving Cubans to win their own place among the world's free people."1 Although the Platt Amendment somewhat limits Cuban freedom, Long confesses, yet it assures the Cubans a "security from rebellion at home and from enemies abroad."2

Under the protection of the United States, "though disturbed at times by temporary upheavals," Cuba, Fite believes, "has had on the whole a happy history.", Indeed, "every citizen of the United States ought to feel proud of our treatment of Cuba," declares Halleck. "In all history no country has acted more generously toward another."4

To no less degree are the Philippines said to be benefited by contacts with the United States since 1898.

The surprising result of the war [says Long] was that the Philippine islands came without forethought or welcome into America's possession. . . . The amazing feature of this expansion [of territorial

${ }^{1}$ Long, America, p. 460. See also Muzzey, An American History, p. 461; Thwaites and Kendall, $A$ History of the United States, p. 471; Hart, School History of the United States, p. 450; Gordy, History of the United States, p. 435; Garner and Henson, Our Country's History, p. 535; Robbins, School History of the American People, pp. 468-69; Thompson, History of the Pcople of the United States, pp. 450-51.

${ }^{2}$ Ibid.

${ }^{3}$ Fite, The United States, p. 400.

${ }^{4}$ Halleck, History of Our Country, p. 441. See also for Cuban-American relations, Hall, Smither, and Ousley, $A$ History of the United States, pp. 438-39; Fish, History of America, pp. 476-77; Hulbert, United States History, p. 488; Beard, History of the United States, pp. 518-19. 
possessions of the United States] is that no statesman planned it, that no party desired it. When we fought to make Cuba free we had no thought of distant lands or empire, and lo! islands and empire were forced upon us. ${ }^{5}$

To these new possessions, according to Long, the United States went "as a liberating rather than as a conquering nation." "The Philippines," he assures his readers, "are ours not to exploit but to develop, to civilize, to educate, to train in the science of self-government." It was difficult, this author continues, for the Filipinos to believe our sincerity and to comprehend fully our statement that we came "as a liberating nation," for other nations "had ruled Eastern lands but left natives much as they found them.",

"After order was restored, our Government established among them schools and libraries," declare Thwaites and Kendall. Besides these spiritual contributions, the Americans have developed industries, improved sanitary conditions, and improved conditions in general. Indeed, according to Long, "It would take a volume to tell the story of American work in the Philippines, the sacrifice, the enthusiasm, the success of it."'

The granting of self-government to these people is mentioned frequently, but most authors point out that "it is not generally believed that the time has yet come for the United States to grant independence. . . . " As According to Horne, "Our pledge to free them still stands; but the time when they are to be trusted to self-government does not seem to have arrived." That "there is a strong feeling in the United States that the Philippines ought

${ }^{5}$ Long op. cit., pp. 460-62.

'Ibid., pp. 466-68.

${ }^{7}$ Ibid., pp. 468-72. For improvements in conditions on these islands see, for example, Thwaites and Kendall, op. cit., p. 474; Robbins, op. cit., pp. 470-71; McLaughlin, History of the American Nation, p. 521; Garner and Henson, op. cit., p. 536; Leonard and Jacobs, The Nation's History, pp. 487-88; West, The Story of Our Country, p. 465; Gordy, op. cit., p. 431; Mace and Bogardus, History of the United States, p. 379.

${ }^{8}$ Fite, op. cit., p. 401. Also Forman, Adranced American History, pp. 527-28.

- Horne, The Story of Our American People, II, 361. 
to be given self-government as soon as there is a reasonable prospect of success" is the view of McLaughlin and Van Tyne. ${ }^{10}$ As to the accomplishment of this fact, Muzzey expresses a skepticism in declaring,

The professed policy of our government ever since the Spanish War has been to give the Filipinos their independence "when they are fit for it"; but as yet we have been unwilling to part with so rich and populous a domain as the Philippine Islands or abandon so fine a strategic post in the Far East. ${ }^{11}$

Yet as governed by the United States the islands are said to have profited, for the policy of America is held to be "liberal" and generally productive of good. ${ }^{12}$

"Having done so much for the people of the Philippines, Congress in 1917 did more for the people of Porto Rico," says McMaster. "It not only gave to them the right to elect members of both houses of their legislature, but made them citizens of the United States."13

The financial help "generously" given the Porto Ricans soon after they came under the control of the United States is mentioned by Gordy, ${ }^{14}$ and other writers include in the benefits derived from American control, not only material advantages such as good roads and the development of intensive production of sugar, but the "inspiring" progress made by education. ${ }^{15}$

The importance of the Hawaiian Islands from a military as well as a financial point of view receives major emphasis in the textbooks. The nearness to the Philippines, the desirability of p. 442 .

${ }^{10}$ McLaughlin and Van Tyne, A History of the United States for Schools,

${ }^{11}$ Muzzey, op. cit., p. 460.

${ }^{12}$ On this point Beard points out that, regardless of the "liberal" policy, independence is still desired by the natives.

${ }^{13}$ McMaster, A School History of the United States, p. 491.

${ }^{14}$ Gordy, op. cit., p. 433.

${ }^{15}$ Fite, op. cit., pp. 400-401; Burnham, The Making of Our Country, p. 561 . 
ownership by the United States as opposed to the disadvantages of ownership by other powers, are not ignored in the discussions. ${ }^{16}$ According to Long, we owe

our valuable possession [of Hawaii] to New England missionaries, who won the friendship of the natives (1820) and created such a strong American sentiment, that, when European powers attempted to seize the islands, the natives appealed to our government for protection and promptly received it. ${ }^{17}$

The customary treatment of acquisition is illustrated by James and Sanford, who point out that the Revolution of 1893 in Hawaii was "incited by Americans," in which the queen was deposed, followed by American recognition of the provisional government. $^{18}$

American control of the Panama Canal region is treated with little openness by writers of textbooks. Certainly it is not set forth that there is any question either as to the advisability or as to the right of the American attitude toward the Panama Revolution. This does not mean that the skirts of the United States government are deliberately cleared of any selfish interest in the revolution, but it means that such an interest is not, as a rule, expressed in the discussions. The unwillingness of Colombia to sell the canal strip, the annoyance of Roosevelt because of Colombia's refusal, the desire of the people of Panama for a canal, the Panama revolt, and the presence of the United States naval forces "to watch the course of events" are points brought out in some discussions. ${ }^{19}$ West and Horne make so bold as to

${ }^{16}$ Hall, Smither, and Ousley, op. cit., p. 437; Beard, op. cit., p. 482; Stephenson, A School History of the United States, pp. 413-14; Thwaites and Kendall, op. cit., p. 475; Channing, Elements of United States History, p. 336; Halleck, op. cit., pp. 441-42; Thompson, History of the People of the United States, p. 449; Elson, United States: Its Past and Present, pp. 483-84; Woodburn and Moran, Elementary American History and Government, p. 419; Forman, op. cit., p. 510; McLaughlin and Van Tyne, op. cit., p. 413; Bourne and Benton, History of the United States, p. 480; Long, America, pp. 472-73.

${ }^{17}$ Long, op. cit., p. 472.

${ }^{18}$ James and Sanford, American History, p. 485.

${ }^{19}$ Beard and Bagley, History of the American People, p. 601; Beard, op. cit., pp. 508-9; Estill, Beginner's History of the United States, p. 285; 
say that Americans "encouraged a revolt in Panama," the latter suggesting that as a result of this incident "many South Americans thus came to distrust us." 20 According to West, "American naval forces were so disposed as to assist the revolution materially; and ex-President Roosevelt has acknowledged that the revolt was directly manipulated from Washington. (Said he frankly some years later, 'I took Panama.')" Ac1 Acording to Forman, "in hot-footed haste [Roosevelt] recognized the new government organized by the seceding State."22 Such statements do not appear often, however.

The payment later of $\$ 25,000,000$ to Colombia "to remove any ground for belief that a sister republic had been unjustly treated" might, if so stated, occasion in the reader a suspicion that some question as to the action of the United States had arisen. ${ }^{23}$ Many textbooks fail to mention the appearance of American naval forces in Colombian waters during the revolution. ${ }^{24}$ The reluctance of Colombia to release the canal strip to the United States is generally regarded as due to selfish motives and a desire to get all she could. ${ }^{25}$ The value of the canal from a financial point of view is given much attention. ${ }^{26}$

Woodburn and Moran, op. cit., p. 426; Fite, History of the United States, p. 519, illustrate typical treatment.

${ }^{20}$ Horne, op. cit., II, 467.

${ }^{21}$ West, History of the American People, p. 644.

${ }^{22}$ Forman, op. cit., p. 541. $\quad{ }^{23}$ Robbins, op. cit., p. 481.

${ }^{24}$ For example, the following do not mention American naval forces: Eggleston, First Book in American History; Hall, Smither, and Ousley, op. cit.; McMaster, op. cit.; Stephenson, op. cit.; Hart, op. cit.; Mace, School History of the United States; Thompson, First Book in United States History; Gordy, op. cit.

${ }^{25}$ McLaughlin, op. cit., p. 525; Elson, op. cit., p. 494.

${ }^{28}$ Thompson, History of the People of the United States, pp. 452, 454; Eggleston, op. cit., p. 194; West, The Story of Our Country, p. 470; Burnham, op. cit., pp. 566-69; Estill, op. cit., pp. 284-85; Barnes, Short American History for Grades, p. 336; Barnes, American History for Grammar Grades, pp. 354-55; Leonard and Jacobs, op. cit., p. 482; Mace, op. cit., p. 462; Thompson, First Book in American History, p. 366; Halleck, op. cit., pp. 489-90; Gordy, op. cit., pp. 441-42. 
The expansion of the United States through the establishment of protectorates is not accorded much consideration in the commonly used histories. The setting-up of protectorates over Santo Domingo, Nicaragua, and Haiti is explained on the basis that such action prevented "a hostile European power" from becoming "a source of danger to American interests." 27 In the case of Santo Domingo, the influence of the United States is ascribed to the effectiveness of the Monroe Doctrine that caused the world to open its eyes. "The practical effect was to make Uncle Sam a kind of policeman for the western hemisphere." 28

The necessity of a supervision of the affairs of Nicaragua is ascribed to the danger which might be occasioned were a foreign power to seize territory near our canal, or, perhaps, dig another canal through Nicaragua. ${ }^{29}$

Thus, according to Hall, Smither, and Ousley:

By various steps, either in the enforcement of the Monroe Doctrine or to protect our own interests by guarding the approaches to the Panama Canal, we have adopted a kind of supervision over many of the islands of the Caribbean Sea and the mainlands bordering on its waters. Santo Domingo, Haiti, Venezuela, and Nicaragua were all heavily in debt to European powers. Upon the appeal of these countries, or in order to prevent foreign intervention and occupation which would be a violation of the Monroe Doctrine, the United States has assumed a certain degree of authority in the management of their finances for the payment of their debts. We have gained control of all available canal routes and have been granted coaling stations and naval bases. ${ }^{30}$

"In line with this policy of guarding American interests in the Caribbean was the purchase of the Danish islands," assert

${ }^{27}$ Beard and Bagley, op. cit., p. 611. The quotation refers to Haiti in particular. See also Long, op. cit., p. 445; Beard, op. cit., p. 513; Garner and Henson, op. cit., p. 606; Gordy, op. cit., pp. 436-37; West, The Story of Our Country, p. 470; Elson, op. cit., p. 517; Woodburn and Moran, op. cit., p. 515; Mace and Bogardus, op. cit., p. 413.

${ }^{28}$ Forman, op. cit., p. 543.

${ }^{29}$ Long, op. cit., pp. 479-80.

${ }^{30}$ Hall, Smither, and Ousley, A History of the United States, pp. 460-61. 
Beard and Bagley. ${ }^{31}$ The strategic advantages of an ownership of the Virgin Islands is likewise discussed by other authors. ${ }^{32}$

Such intervention in the affairs of neighboring peoples has been adjudged a good thing, for

wherever national duty imposes on them tasks of colonial administration be it in the Orient or in the Occident, Americans at once gather the youth of the land which is placed in their charge, into public schools like those of the United States. The public school is a storehouse of national well-being for all peoples. ${ }^{33}$

The policy is clearly depicted as a means for national defense. "Since we have become a world power we must play the game of world politics," declares Long. "For us the first object of that dangerous game is not to get more territory but to guard our national peace and safety." ${ }^{94}$ The influence of economic forces as a factor in the American adventure into the Caribbean is not set forth for the pupil. The Story of Our Country is unique in stating that our military officers have sometimes used their authority in "very arbitrary and un-American ways."35

${ }^{31}$ Beard and Bagley, op. cit., p. 613.

${ }^{22}$ Beard, op. cit., pp. 479-80, 593-94; Barnes, Short American History for Grades, p. 382; Fite, The United States, p. 410; Garner and Henson, Our Country's History, p. 606; Mace, op. cit., pp. 474-75; Halleck, op. cit., p. 491; McMaster, op. cit., p. 491; Woodburn and Moran, Elementary American History, p. 437; West, The Story of Our Country, p. 471; Bourne and Benton, op. cit., p. 485; Robbins, op. cit., p. 482; Guitteau, Our United States, p. 482.

${ }^{33}$ Fite, The United States, p. 409.

${ }^{34}$ Long, op. cit., p. 480.

${ }^{35}$ West, The Story of Our Country, p. 471. 


\section{CHAPTER X}

\section{THE FOREIGN POLICY OF THE UNITED STATES}

Although introduced at other points in this study, it may be well to add a few statements concerning discussions relating to the foreign policy of the United States-a policy inaugurated by Washington and receiving universal commendation. All authors are agreed that Washington's policy was the only feasible and sensible procedure open to the United States at that time. ${ }^{1}$ Its significance in establishing an isolation for the United States and in keeping this country out of "European quarrels" is mentioned. ${ }^{2}$ Such, indeed, is held highly desirable according to the textbooks.

The same favorable treatment as given Washington's policies is accorded the Monroe Doctrine. Far more space in the histories is devoted to its pronouncement and its earlier applications than to the significance of its later growth and applications, which are inadequately and superficially dealt with.

It is generally conceded to have been a "necessary" as well as a beneficial doctrine not only for the United States but for those nations to whom it was to apply.

Its main motive, according to McLaughlin, who quotes Schouler on this point, was "to shelter honorably those tender blossoms of liberty on kindred soil from the cold Siberian blasts

${ }^{1}$ See, for example, West, The Story of Our Country, p. 234; Fish, History of America, p. 202; Evans, The Essential Facts of American History, pp. 242-43; Channing, A Students' History of the United States, p. 243; Hart, Nere American History, p. 223; Guitteau, Our United States, p. 245; Robbins, School History of the American People, p. 193; McLaughlin and Van Tyne, $A$ History of the United States for Schools, p. 240; Mace, School History of the United States, p. 228.

${ }^{2}$ See, for example, Mace, School History of the United States, p. 228; McLaughlin and Van Tyne, $A$ History of the United States for Schools, p. 240. 
of despotism."3 The United States is made, therefore, the "champion of freedom throughout the two Americas."4

The effect of its declaration upon the American people is held likewise profoundly beneficial, for it made men whose political horizon had been limited to a community or a state "consider their nation a great power among the sovereignties of the earth, taking its part in shaping their international relations."5 The approval of the Doctrine by the American people and its gradual incorporation into the consciousness of the United States served as bulwarks for a growing nationalism. ${ }^{6}$ That the Doctrine was not unanimously indorsed by people of its time is mentioned by Bourne and Benton. ${ }^{7}$

Europe also gave heed, for, according to Gordy, although "a vigorous position to take," the Americans had won respect through "the valor and heroism of our fighting on land and sea, and the brilliant victories already achieved." "That Europe has not always liked the Doctrine but has not dared disregard it is called to the reader's attention by Thompson and Barnes. ${ }^{9}$

The "triumphs" of the Doctrine, whenever applied to international disputes, are chronicled in connection with the portions of this study dealing with the different countries concerned. As a doctrine of peace and a preserver of democracy, it receives in the textbooks the approval of their authors. ${ }^{10}$

${ }^{3}$ McLaughlin, History of the American Nation, pp. 273-74.

"Robbins, School History of the American People, p. 212.

${ }^{5}$ Beard, History of the United States, p. 207.

${ }^{\circ}$ See Forman, Advanced American History, p. 260; Fish, op. cit., p. 215; Beard and Bagley, First Book in American History, p. 194.

${ }^{7}$ Bourne and Benton, American History, p. $27 \%$.

${ }^{8}$ Gordy, History of the United States, p. 235.

- Thompson, First Book of United States History, pp. 255-56; Barnes, Short American History, pp. 178-79.

${ }^{10}$ See Elson, United States: Its Past and Present, p. 288; Mace and Bogardus, History of the United States, p. 223, for examples of this point. 


\section{CHAPTER XI \\ POLITICAL CONCEPTS}

The American public school, through the agency of the textbook, is definitely committed to inculcating in the pupil's mind political concepts held to be mainly American. These include concepts transmitted to the present generation through a period of change, development, and adjustment, as well as the original theories respecting the rights and duties of man under government, as bequeathed by our American forbears. History textbook writers, very naturally, leave to the authors of books on government extensive discussions of these factors in American life. But historians do not fail to note their significance in the political history of the country.

Among the "rights" inherited by the American people, according to the textbooks, are the right of petition, free speech and press, religious freedom, the right of holding property, freedom of person, and trial by jury.

The obligation of the citizen to his government likewise receives attention. Those political documents which have held and secured the rights and privileges of Americans, the character and structure of the government, and recent innovations, such as the recall, are not unnoticed. The rule of the people, in which there is a majority as opposed to minority opinion, most often expressed through political parties, the delights of democracy proclaimed because of the "consent of the governed," make of our government, in the words of a textbook writer, "the largest and most promising of mankind's experiments in this difficult field of self-government by an entire people." $\mathrm{He}$ declares:

Our country has developed into a true Representative Democracy. That is, our people select their own officials, and have all an equal vote in changing them when necessary. These representatives are pledged to direct our Government for the equal benefit of us all.

${ }^{1}$ Horne, The Story of Our American People, I, 3. 
There is the same law for all, the same permissions and the same restraints. That is the nearest approach to the ideal of EQUALITY that man has yet been able to attain. ${ }^{2}$

That "democracy is considered the ideal form of government by most of the civilized world" is made an accepted truth. ${ }^{3}$ The reasonableness and effectiveness of the representative system are stressed as well. ${ }^{4}$ Through such a system, liberty, the boon offered by America to all, according to the writers, was preserved. As a tool in its preservation is the law, written or unwritten, toward which obedience is owed by all to whom it offers protection. $^{5}$

As setting forth the principles of government, the most frequently discussed political documents are the Mayflower Compact, the Declaration of Independence, the Articles of Confederation, the Constitution, and the state constitutions. The Northwest Ordinance is also frequently treated.

According to Hart, the great principles contained in the state constitutions, the Declaration of Independence, and the Articles of Confederation are:

(1) A written constitution is a "fundamental law" which cannot be altered by an ordinary law of a legislature or congress. ....

(2) The old doctrine of "natural rights" or "fundamental rights" or "inalienable rights" was claimed in the Declaration of Independence, and enlarged and stated in the "bills of rights" which were added to the state constitutions. . . . .

(3) The Americans wanted a popular government in which there should be no king, no nobles, no privileged classes. . . . . ${ }^{6}$

The praise given these bulwarks of American freedom is not scant in any sense. The Declaration of Independence is said to

${ }^{2}$ Ibid.

${ }^{3}$ Fite, History of the United States, p. 177.

'See, for example, statements bearing out this point in McLaughlin, History of the American Nation, p. 134; Daffan, History of the United States, p. 49; Fish, History of America, p. 145.

${ }^{5}$ Fish, op. cit., has developed this probably to the greatest degree of any of the high-school histories.

' Hart, School History of the United States, pp. 151-52. 
be "truly immortal,"7 "a great human document," and "the most famous document known in the history of our country." The Constitution is adjudged "the most marvelous written political instrument that has ever been made." 10 Evans describes it as a "noble instrument . . . made by the greatest men of our nation." 11

A monumental episode in the world's history, the American Constitution! [Long declares, quoting A. Maurice Low] Never was there anything like it. . . . The history of mankind is a struggle for liberty and equality. From the time that men began to teach and to preach they taught liberty and proclaimed equality; but neither liberty nor equality existed as we today know them, until they were written into the American Constitution, there to remain and to be a beacon-light to all the world. ${ }^{12}$

The famous remark of Mr. Gladstone, that the United States Constitution was "the most wonderful work ever struck off at a given time by the brain and purpose of man," likewise finds a place in the textbooks. ${ }^{13}$

Leonard and Jacobs, in The Nation's History, confess that "the Constitution of the United States may not be perfect; but it is the best constitution which the wisest Americans of $\mathbf{1 7 8 7}$ were able to make, and it has stood the test of time." ${ }^{14}$

${ }^{7}$ Beard and Bagley, History of the American People, p. 150.

${ }^{8}$ Fite, op. cit., p. 133. See also Woodburn and Moran, Elementary American History and Government, pp. 143-44.

- White, Beginner's History of the United States, p. 137. See also Channing, Elements of United States History, p. 145; Hart, op. cit., pp. 148-49; Elson, United States: Its Past and Present, pp. 139 ff.; Burnham, The Making of Our Country, pp. 135-36; Bourne and Benton, American History, pp. 119-21.

${ }^{10}$ Channing, A Students' History of the United States, p. 220. See also Fish, op. cit., p. 178; Elson, op. cit., p. 206; Mace and Bogardus, History of the United States, p. 158; Fite, The United States, p. 185; McLaughlin, op. cit., p. 196.

${ }^{11}$ Evans, The Essential Facts of American History, p. 234.

${ }^{12}$ Long, America, p. 221.

${ }^{13}$ EIson, op. cit., p. 195; Burnham, op. cit., p. 167.

${ }^{14}$ Leonard and Jacobs, The Nation's History, p. 215. 
Its perfection is further attested to by Horne, when he points out:

Many written constitutions have since been prepared by various nations; but they all had this one for a model. Our founders had no similar document to go by. They drew their ideas from the Declaration of Independence, from colonial charters, from the practical experience of each colony in self-government, and from their own broad knowledge of mankind. The Constitution established the basic, unchanging principles of our American philosophy of government. It fitted the moment and the need, as no other government could have done. Yet in matters of detail it contained such wise provisions for its own change that we have ever since been able to alter it to fit new conditions and new generations of men. ${ }^{15}$

Duty to a constituency and the necessity of honesty in office are qualities mentioned as desirable for public officials. "But where dishonesty by a man in public office has been proved he may be regarded as little better than a traitor," declares Robbins. ${ }^{16}$ Discussions of corruption in Grant's administrations frequently emphasize the dangers of such a condition, and the influence of public opinion in getting upright officials is a point made occasionally in connection with the duties of a voter. ${ }^{17}$

Advocacy of civil service reform and disapproval of the spoils system have their place in the textbooks. ${ }^{18}$ Throughout, however, the space allotment is far less than in books designed primarily for the student of government.

${ }^{15}$ Horne, op. cit., I, 428-29.

${ }^{16}$ Robbins, School History of the American People, p. 539.

${ }^{17}$ McLaughlin, op. cit., p. 521.

${ }^{18}$ See, for example, Evans, op. cit., pp. 424-25; Robbins, op. cit., pp. 252 , 424-25; Fite, History of the United States, pp. 278-79; McLaughlin, op. cit., pp. 292-93; Beard, History of the United States, pp. 538-39; Beard and Bagley, First Book in American History, p. 205; Barnes, Short American History by Grades, p. 194; Fite, The United States, p. 262; Garner and Henson, Our Country's History, pp. 495-96; Thwaites and Kendall, $A$ History of the United States, pp. 437-38; Mace and Bogardus, op. cit., p. 227; Leonard and Jacobs, op. cit., pp. 408, 279; Halleck, History of Our Country, p. 315; Gordy, History of the United States, p. 250. 


\section{CHAPTER XII}

\section{THE AMERICAN : HIS ACHIEVEMENTS, IDEALS, AND COUNTRY}

Closely allied with the political concepts gained from reading history textbooks are attitudes and ideals, some of which are political, set up regarding the character and prowess of the United States. Here by direction and indirection the writers of textbooks have created impressions regarding American customs, institutions, and ideals which tend to separate the United States from other nations. The boon of freedom, denied to many peoples, the wonders of democracy and the democratic principles of the American people as presented to pupils inevitably must make a lasting impression. Through all runs the story of the superiority of a people able to create and to attain the unusual.

Our country [says Long] began at a time when kings misruled the world, when government was considered such a difficult science that only a few trained nobles could understand it. . . . . Yet our colonists quickly mastered the practical art of government; . . . . in the field of politics the American people have done three extraordinary things:

1. They have constantly aimed to govern themselves instead of tamely submitting to be governed by others, as most of the world's people have submitted up to recent times.

2. They changed the nature of government, as men formerly understood it. . . . .

3. Following their own theory of government the American people have been steadily removing every form of class privilege; that is, a right given to one class of people which is not equally given to every other class..... America stands for one folk equal before God and man in their rights and privileges. That is the pride of our democracy, and the wisdom and power of it. ${ }^{1}$

All this, according to authors, created in other nations wonderment and surprise, for the unique character of the form of government established by the Revolutionary patriots and since

${ }^{1}$ Long, America, pp. 9-10. 
maintained by "a plain people" aroused an interest in "thoughtful men and women the world over, especially in monarchical Europe, where the common people had little power. ...." "2 For:

- Ours is a government not of force or fear but of ideals. .... Liberty is an American ideal, and every man desires liberty above all other gifts. Justice is an American ideal, and every rightminded man believes in justice. Equality (meaning equal rights) is an ideal in which men have always believed, yet the human quality of all citizens was never admitted by any nation until it was written into the Constitution of the United States. . . . . 3

More than this, the social ideals of the American people have occasioned astonishment in people. They cannot understand how "in all our free America of today, we do not consider one person better than another on account of birth and station." Indeed, it is taught that America is "the greatest democratic nation in the world," the "land of the free and the home of the brave." "5

The Revolution, according to Bourne and Benton, made a nation "dedicated to the ideals of equal opportunity, of inalienable rights, and of government by the consent of the governed. ... It meant, moreover, the presence among the nations of one that knew no caste, no nobility, or other hereditary distinctions. . . . " " For, according to Horne, "there is the same law for all, the same permissions and the same restraints."7 And Fite quotes Crevecour's definition:

Here individuals of all races are melted into a new race of men, whose labors and posterity will one day cause great changes in the world. Americans are the western pilgrims, who are carrying along with them the great mass of arts, sciences, vigor and industry, which began long since in the east. They will finish the great circle. . . . Here they are incorporated into one of the finest systems of popu-

${ }^{2}$ Fite, History of the United States, p. 295.

${ }^{3}$ Long, op. cit., pp. 6-7.

${ }^{4}$ Elson, United States: Its Past and Present, p. 95.

${ }^{5}$ Burnham, Our Beginnings in Europe and in America, pp. 363, 5-6.

${ }^{6}$ Bourne and Benton, American History, p. 160.

${ }^{7}$ Horne, The Story of Our American People, I, 3. 
lation which has ever appeared. . . . The American is a new man, who acts upon new principles; he must therefore entertain new ideas, and form new opinions. . . . . This is an American."

Thus, out of these unusual conditions has come a people who seek "the way of justice," and who follow it "when they have found it" ;" who have the qualities of "good humor, a love of freedom, cheerfulness in bad fortune, generosity in good fortune, warm-heartedness, shrewdness, carelessness of danger, and immense energy," 10 and who are "wide-awake, industrious, and thoughtful men, women and children."11

It is American ingenuity that has placed our country among the first industrial nations of the world, according to Beard and Bagley. ${ }^{12}$ Evidence of this quality is adduced by "the dynamic energy" and "amazing activity" of the Americans upon the entrance of the United States into the World War. ${ }^{13}$

In the arts and sciences, the textbooks describe the American people as having shown a "more wonderful genius for invention than those of any other country."14 Indeed, according to one textbook, "The American invents as the Greek chiseled, as the Venetian painted, as the modern Italian sings." 15

"Americans are celebrated for their skill in adapting scientific knowledge to useful ends," says Stephenson. ${ }^{16}$ In the field of literary endeavor, American newspapers and magazines are "among the best," and many of our authors, artists, and musi-

${ }^{8}$ Fite, The United States, p. 115.

${ }^{\circ}$ Long, op. cit., p. 429.

${ }^{10}$ Stephenson, A School History of the United States, p. 518.

${ }^{11}$ Hart, School History of the United States, p. 12. See also Long, America, p. 12.

${ }^{12}$ Beard and Bagley, First Book in American History, p. 354.

${ }^{13}$ Elson, op. cit., pp. 523-24.

${ }^{14}$ Thompson, First Book in United States History, p. 346. See also Hart, op. cit., p. 460; Evans, The Essential Facts of American History, pp. 449-85.

${ }^{15}$ West, The Story of Our Country, p. 281.

${ }^{16}$ Stephenson, op. cit., p. 501. See also Thompson, History of the United States, Political, Social, Industrial, p. 151. 
cians are believed to have attained world-wide renown. ${ }^{17}$ Thwaites and Kendall declare:

The religion, literature, and pleasures of the people show what they really are. The United States was simple and clean in its amusements and had ideals that it was not ashamed to show. President Roosevelt's demand for a "square deal" for everyone expressed the desire of a nation that loved clean sport and hated a cheat. The great churches that were being built, from the massive cathedrals in New York, to humble missions in little towns, measured an interest in things of the spirit that prosperity had not lessened..... Throughout the literature and religion ran unceasingly the old American ideals of real democracy. Even the moving pictures, which became more popular than the theater had ever been, expressed these same notions of democracy. .... ${ }^{18}$

For the promotion of intellectual interests, it is agreed that "no country has a more complete system of public schools" than the United States, ${ }^{19}$ for it was early recognized that education was necessary for an intelligent and upright citizenry. ${ }^{20}$

According to Robbins,

It is because democracy means "government of the people, by the people" that education has always been a matter of such grave concern to good citizens of our republic. Our people may be expected to rule their country the more wisely as they are the more educated. ${ }^{21}$

In providing for education, the United States, according to Hall, Smither, and Ousley, "is the foremost in the world."22 The

${ }^{17}$ Hall, Smither, and Ousley, A History of the United States, p. 522; Fite, History of the United States, p. 298; West, op. cit., pp. 493-94.

${ }^{18}$ Thwaites and Kendall, A History of the United States, pp. 486-87.

${ }^{19}$ The statement of Stephenson, op. cit., p. 503.

${ }^{20}$ Horne, op. cit., II, 485; I, 218. See also Thwaites and Kendall, op. cit., p. 423.

${ }^{21}$ Robbins, School History of the American People, p. 530. See also Woodburn and Moran, Elementary American History and Government, p. 502; Gordy, History of the United States, p. 539.

${ }^{22}$ Hall, Smither, and Ousley, op. cit., p. 514. See also for American education, Eggleston, First Book in American History, p. 97; Vollentine, The Making of America, p. 245; Fite, The United States, p. 385; Garner 
American people, it is held, have become obsessed with "a popular passion" for education, which has made it possible for all to have an education. This popular fancy for education is additional proof that Americans are "concerned with matters of the spirit as well as with material things."23

In our relationship with other nations, the histories describe the United States as always willing to help the distressed and as being of service, in innumerable ways, to the whole world.

"The United States, now the leading power of the world," declares Barnes, "has done more for world advancement than any other nation ....." Indeed, it is the natural instinct of Americans to help the distressed, or as one textbook puts it, act as "Good Samaritans." 25 As examples of this generous spirit, the writers of histories mention "how Americans saved the world from a scourge (yellow fever)" $;^{26}$ how Americans came to the aid of the Cubans for "humanity's sake" $;{ }^{27}$ how we sent for relief to the starving people of Russia "twenty million dollars" in $1921 ;^{28}$ how we have maintained a generous attitude toward China $;^{29}$ how, in the World War, we became the defender of humanity. ${ }^{30}$ In this last connection it is said that our unselfishness is well demonstrated in the amount of money spent when we were " 'seeking nothing for ourselves but what we shall wish to share with all free peoples." ",31

and Henson, Our Country's History, p. 570; West, The Story of Our Country, pp. 495 ff.; Rugg, Pamphlets, I, 167-68; 173-74; Mace and Bogardus, History of the United States, p. 424; Halleck, History of Our Country, p. 527.

${ }^{23}$ Thwaites and Kendall, op. cit., p. 423.

${ }^{24}$ Barnes, American History for Grammar Grades, pp. 425-26.

${ }^{25}$ Halleck and Frantz, Our Nation's Heritage, p. 408.

${ }^{26}$ Ibid., pp. 408-9.

${ }^{27}$ See Horne, op. cit., II, 350; Leonard and Jacobs, The Nation's History, p. 475; Halleck and Frantz, op. cit., pp. 406-7; Muzzey, An American History, p. 452.

${ }^{28}$ Elson, op. cit., p. 540.

${ }^{29}$ Halleck and Frantz, op. cit., pp. 407-8.

${ }^{30}$ The point of view of substantially all histories.

${ }^{31}$ Halleck and Frantz, op. cit., p. 408. 
In the World War, moreover, our service to humanity is said to have gone beyond the giving of money, for we are described as "Crusaders of old," who went forth to secure for all mankind "the right of self-government." trol over any part of Europe's future, no security even for the payment of our debts. We left behind us only the graves of our men, who had died there that the world might be free." 33

In all our generosity, according to Halleck and Frantz, we do not consider the "almighty dollar." We have far less "narrowness" than other nations, another writer tells us, and "give fair play even to the weakest.",35

Thus, the United States has come to be thought "a kind of paradise, a land of hope" by "the poor folk and oppressed of other lands," for it is known "as the land where work brings its best reward, the one region where Peace seems assured, the land of Opportunity." Indeed, "the leaders of other countries," as well as the poor and oppressed, are said to "turn to the United States. They know it as a land of Power, able to help them in their political troubles, yet not grasping at their rights. They seek our young strength and energy to aid in solving the world-made problems of government at home and trade abroad.",36

In other ways than in protecting and aiding the weak and defenseless, the United States is believed to have been "of service to the Old World." Washington, Franklin, and Lincoln have influenced the history of all peoples; we have "performed a great service for humankind by inviting immigrants to come to our shores as long as there was plenty of good land"; the American "contribution to free government" is inestimable for we have been a powerful advocate of democratic ideals the world over. ${ }^{37}$ Then in the merely material, we have become "the granary of the world," a country to which "men come .... from all lands when they desire to borrow money." In other words, "we have

${ }^{32}$ Guitteau, Our United States, pp. 632-33.

${ }^{33}$ Horne, op. cit., II, 444.

${ }^{34}$ Halleck and Frantz, op. cit., p. 406.

${ }^{35}$ Horne, op. cit., II, 288; I, 2.

${ }^{36}$ Ibid., p. 1.

${ }^{37}$ Halleck and Frantz, op. cit., pp. 408-13, 398-406; Gordy, op. cit., p. 419. 
advanced from our former isolation to a position of leadership in the world," in which "we have a great part to play.",38

In American industrial life, there has been an astonishing development, according to the textbooks. "America has become one of the first workshops of the world," says Beard, in commenting upon the closely knit character of our business organization. ${ }^{39}$ The United States is said also to be "the chief exporting nation of great staples like foodstuffs and steel," whereas New York has become "the money, banking, and credit center of the world." 40 From fourth in the production of manufactured goods in 1860 , the United States advanced during the thirty years following to first place, and now holds the rank of "the leading manufacturing nation of the world." 41

Such conditions have brought about "prosperity" to a degree unknown to other nations. ${ }^{42}$ America has become "the richest country in the world."43

Aiding the ingenuity, inventive skill, and energy said to be characteristics of the American, have been the natural resources of the country ${ }^{44}$ embraced in a territory larger than Western and Central Europe. ${ }^{45}$ In about "sixty years" this vast area

${ }^{38}$ Burnham, The Making of Our Country, pp. 597-98. See also Stephenson, op. cit., pp. 382, 480; Woodburn and Moran, op. cit., p. 530; Evans, op. cit., p. 530 .

${ }^{39}$ Beard, History of the United States, p. 475. See also for attitude toward capitalist class, Stephenson, op. cit., p. 501.

${ }^{40}$ Rugg, Pamphlets, II, 193. See also Guitteau, op. cit., pp. 554 ff.; Figgleston, First Book in American History, p. 197; Vollentine, op. cit., pp. 235-55.

${ }^{41}$ Woodburn and Moran, op. cit., p. 471.

${ }^{42}$ Barnes, op. cit., p. 268. See also among others, Muzzey, op. cit., pp. 420, 464, 518; Fish, History of America, p. 24.

${ }^{43}$ Mace and Bogardus, op. cit., p. 360 . See also Thompson, History of the People of the United States, p. 503; Woodburn and Moran, op. cit., pp. 468-70, 525.

${ }^{44}$ Muzzey, op. cit., p. 22; Hart, Nere American History, p. 8; Forman, Advanced American History, pp. 60-61; Gordy, op. cit., p. 550.

${ }^{45}$ Rugg, op. cit., I, 11; Stephenson, op. cit., pp. 483-84; Halleck, op. cit., p. 528; Elson, op. cit., pp. 178-79. 
was transformed into "the richest industrial nation of the world." ${ }^{46}$

Such conditions in a country naturally lured to our shores many peoples. For is this not the "land of opportunity?"47 Burnham declares:

Nearly all the people who have come from Europe to America, from its earliest history to the present time, came because they wanted to be free, or because they wanted a better chance to make a living than the Old World could give them. Some of them fled from the tyranny of wicked kings; others came to win the right to worship God in their own way; while many were driven out by the want and poverty in the overcrowded lands of their old homes. America has been the land of liberty and opportunity to one and all from the earliest to the latest comer. ${ }^{48}$

All this opportunity, according to Horne, in The Story of Our American People, seems to have been reserved for a chosen people by Divine Providence.

The fact that our continent lay so long unused has seemed to many earnest thinkers one of the world's most striking manifestations of the Divine Purpose of God. They have believed that all this wealth of field and forest and mines was held untouched until civilization should grow worthy of it. America was to be a new rich heritage for man, not to be revealed to him until he had learned how to conserve it, how to govern both it and himself. ${ }^{49}$

Thus there came to inhabit the "promised land,"50 due to "a Divine Purpose working out some mighty aim for America,"

${ }^{46}$ Rugg, op. cit., II, 213, 290-91. Further references to the "prosperity" of the United States might be added, including Hart, School History of the United States, pp. 459-60; Beard, op. cit., p. 477; Halleck, op. cit., p. 368; Elson, op. cit., p. 525; Guitteau, op. cit., pp. 642-44; Woodburn and Moran, op. cit., p. 385.

${ }^{47}$ Fish, op. cit., pp. 12, 26. See also McLaughlin, History of the American Nation, p. 293; West, The Story of Our Country, pp. 422, 62; Long, op. cit., p. 523.

\footnotetext{
${ }^{48}$ Burnham, Our Beginnings in Europe and America, pp. 4-5.

${ }^{49}$ Horne, op. cit., I, 6.

${ }^{50}$ Daffan, History of the United States, p. 1.
} 
"some of its [Europe's] richest seed," destined to be the ancestors of "a new race, the "Americans." 'This chosen group sometimes contained

folk convicted as criminals; but laws have not always judged men as God judges them, and the governments of those days were apt to be harsh and narrow..... Men dwelt in ignorant terror of the law. ... . Some of the convicts sent here were indeed evil-minded rascals; but many were men we would have applauded for their so-called crimes. Moreover, even the real criminal, on being exiled here, had to develop a large strength of manhood-or he perished. ${ }^{51}$

For these unexcelled blessings, the pupil is urged to follow in the footsteps of his forbears, to offer unquestioning obedience to the law of the land, and to carry on the work begun.

If the children of America grow up truthful and pure and brave, proud of their country, and loving God and their fellow men, [declares Estill] if they have the wisdom of Benjamin Franklin, the patriotism of George Washington, the rugged honesty of Abraham Lincoln, the devotion to duty of Robert E. Lee, and Woodrow Wilson's love of freedom for all mankind-if they copy the virtues of their fathers and avoid their faults, the future of our country will be even greater and more glorious than the past. $^{52}$

Our [United States'] future will be determined by the character of our citizens [says Gordy]. We can make the coming years more glorious than the past, if we hold to the ideals of those patriots who have built up our great republic. We owe it much. From the very beginning it has offered freedom of opportunity to all. In return, let us give loyalty and willing support to its great democratic principles and institutions.

The national flag, our own "Stars and Stripes," is the supreme symbol of our republic and its wonderful achievement. Let us pledge allegiance to this flag, and let it inspire us with love for our country and with an abiding faith in its high destiny. ${ }^{53}$

The rendering of homage to the flag as the token of the unity of forty-eight states is held the means of quickening the patriotic pulse of the pupil. Therefore by law, it appears over the school-

${ }^{51}$ Horne, op. cit., pp. 7-11.

${ }^{52}$ Estill, The Beginner's History of Our Country, p. 323.

${ }^{53}$ Gordy, op. cit., p. 550. 
houses of the land and its replica is found in the textbooks. Doubtless, for this purpose the American Legion is said to have sponsored a movement, in Kansas, placing in a million textbooks published in that state and used in the state's schools in 1926 the picture of the national emblem. ${ }^{54}$

Just what this love for country really means the textbook writers sometimes attempt to say.

Patriotism or love of country [Halleck declares] begins first with an appreciation of the service rendered us in our own homes, and then extends to our neighborhood, state, and country. . . . Patriotism is more than saluting the flag. It is enlisting for life in active service for our country. We may challenge any one to name a country in the world that has done more for its citizens or given them a greater chance for success. The flocking of millions of immigrants to the United States bears witness to the greatness of its service, which it is our patriotic duty to repay. George Washington, however, never excused himself from taking his part in the service of his country by asking: "What has my country done for me?" His question was: "What can I do for my country?" It is to such men that we owe our national existence and welfare. ${ }^{55}$

According to Horne,

True patriotism consists in guiding our land, not in making empty boasts of its perfection. Patriotism is not a blind acceptance of everything about us, but a love for the Spirit which we believe our land to represent. For us that Spirit is shrined in democracy's motto: "Liberty, Equality, Fraternity." Liberty means command of the self within us; Equality means justice to others; and Fraternity means love for all.

To aid in establishing and maintaining these, true patriotism performs its civic duties, even when these call for heavy sacrifice. It obeys our country's laws, even when annoyed by them; and it insists that others shall obey them also. It seeks to improve the future, while holding joyously at heart a deep-felt pride in the past, a love for every foot of our fair land..$^{56}$

${ }^{54}$ Daily Iowan, August 21, 1926, Associated Press report.

${ }^{55}$ Halleck, op. cit., pp. 531-32.

${ }^{\text {s6 }}$ Horne, op. cit., II, 489. 
Pupils reading West's Story of Our Country will find the authors' purpose in writing this history stated thus:

America, your America! In a few years you will have a share in determining what this country shall be for the future. You should know then, what it has been and how it has come to be what it now is. You young Americans all like to salute the flag. That is well, even if you have no better reason than that it is your flag. But it is finer and better for you to love to salute it because you ${ }^{-}$know with a joyous pride that it stands for freedom, for law, for fair opportunity in industry (and so for decent and happy homes), for goodwill to the peoples of other lands. To help you understand how this America of ours has come to stand for these glorious principles is the purpose of this book. ${ }^{57}$

All this tends to develop in the pupil that sense of nationality which Long says is hard to define. ${ }^{58}$ In pointing out some of the characteristics of nationality, he tells his readers:

American nationality means, among other things, that we have a country to honor, to serve, to live for at all times or to die for, as Nathan Hale died, if the stern call comes. It means that all our states are one, and our people one..... If the flag that floats over every public building should suddenly challenge the passing multitude "Who goes?" the instant response would not be a thousand different names but the single, myriad-tongued word "American." That answer, proud and loyal, voices the spirit of nationality.

This unity of citizens outwardly different but inwardly alike is the result of history, of the welding together of a people who face problems, difficulties and dangers all together. ${ }^{59}$

The confession of this spirit of nationality is found in the American's Creed reproduced in some of the histories:

I believe in the United States of America as a Government of the people, by the people, for the people; whose just powers are derived from the consent of the governed; a democracy in a republic; a sovereign nation of many sovereign states; a perfect union, one and inseparable; established upon those principles of freedom, equality, justice, and humanity for which American patriots sacrificed their lives and fortunes.

${ }^{87}$ West, The Story of Our Country, p. xxvi.

${ }^{88}$ Long, op. cit., p. 273.

${ }^{59}$ Ibid. 
I therefore believe it is my duty to my country to love it; to support its Constitution; to obey its laws; to respect its flag; and to defend it against all enemies. ${ }^{60}$

Depicted as worthy of imitation and as of unexcelled loyalty to country are many of the heroic characters common to the history textbooks. Most of these heroes have been engaged either in statecraft or in military exploits. It is safe to conclude that contributors to the acts of peace are not only given far less space in the textbooks than the groups mentioned, but often the language used concerning their achievements is spiritless and lacking in color. As an example of comparative space allotment, Gordy's Stories of Later American History may be cited: War heroes receive 3,227 lines, statesmen 1,160 lines, and those engaged in enterprises of peace, such as philanthropists, scientists, and inventors, 2,335 lines. Thus 4,387 out of a total of 6,722 lines are devoted to those whose interests were chiefly political and military. ${ }^{61}$

In enumerating the characters whose names appear most often in histories, one would naturally expect the name of Columbus, "the one man who had faith and courage enough to cross the Atlantic, and thus point the way to the New World."62

In the Colonial and Revolutionary periods, the reader finds the names of John Adams, "a true patriot and statesman";"63 Samuel Adams, "a tribune of the people" whose own fortune dwindled in his espousal of the cause of the colonists, ${ }^{64}$ and who did more than anyone else to arouse the love of liberty in his colony. ${ }^{65}$ and Patrick Henry, whose "great gift" of oratory

${ }^{\circ 0}$ Found in Hall, Smither, and Ousley, op. cit., frontispiece; Horne, op. cit., II, 525.

${ }^{61}$ Gordy, Stories of Later American History (New York, 1923).

${ }^{62}$ White, Beginner's History of the United States, p. 18.

${ }^{63}$ Elson, op. cit., p. 220.

${ }^{64}$ Bourne and Benton, op. cit., p. 81.

${ }^{65}$ Gordy, Stories of Later American History, pp. 15-29; Mace, Primary History of the United States, pp. 148-50, 151-52, 158; Forman, op. cit., pp. 110, 118; James and Sanford, American History, p. 150. These are typical treatments. 
was "used in helping to secure the freedom we now enjoy.""6 The greatest amount of attention of all, as the reader might expect, is devoted to Washington, "the beacon light" of the Revolution, the one hero and patriot who could not have been replaced. ${ }^{67}$ The contributions of his later life are in no less degree discussed in the highest and most laudatory language. All books read commend his services.

Of other military heroes of this early period there is mention of the services of Ethan Allen, ${ }^{68}$ of Nathan Hale, whose only regret was that he had but one life to lose for his country, ${ }^{69}$ of Herkimer, "the hero of Oriskany,"70 of Nathaniel Greene, Morgan, Marion, Sumter, John Paul Jones, John Barry, Leger, Israel Putnam, John Stark, and Anthony Wayne. ${ }^{71}$ Of course the story of Paul Revere is not omitted, especially in the histories

${ }^{68}$ Gordy, Stories of Later American History, pp. 1-13. See also Bourne and Benton, op. cit., p. 68; Latané, A History of the United States, pp. 99-100, 124; Hart, Nerw American History, pp. 129, 152-53; Muzzey, op. cit., p. 110 ; Mace, op. cit., pp 142-47.

${ }^{67}$ Hart, Nere American History, p. 145. See also Burnham, The Making of Our Country, pp. 153-54; Horne, op. cit., II, 38; Elson, op. cit., pp. 137, 145, 208; Thompson, History of the People of the United States, pp. 164-65; Fish, op. cit., pp. 117, 161; Forman, op. cit., p. 186; Fite, The United States, p. 188; Halleck and Frantz, op. cit., pp. 389-92; Barnes, op. cit., pp. 225-26; Channing, Elements of United States History, pp. 151-52, 165-66, 148; West, The Story of Our Country, pp. 166-67; Woodburn and Moran, op. cit., p. 136; Muzzey, op. cit., p. 130; Gordy, History of the United States, p. 248; Gordy, Stories of Later American History, pp. 45-71; Beard and Bagley, History of the American People, pp. 163-65; Bourne and Benton, History of the United States, pp. 189-90; McLaughlin and Van Tyne, A History of the United States for Schools, pp. 158-59; Fite, History of the United States, p. 181; White, op. cit., pp. 176-77; Mace and Bogardus, op. cit., p. 183; McLaughlin, op. cit., p. 164; Thwaites and Kendall, op. cit., p. 231, and others.

${ }^{68}$ Horne, op. cit., I, 348.

${ }^{68}$ Gordy, Stories of Later American History. See also Robbins, op. cit., pp. 133-34; Guitteau, op. cit., p. 174; Mace, op. cit., pp. 176-77.

${ }^{70}$ Mace, op. cit., pp. 195-97; Horne, op. cit., I, 348, 396.

${ }^{71}$ Mace, op. cit., pp. 194 ff.; Beard and Bagley, First Book.in American History, pp. 128 ff.; Garner and Henson, op. cit., p. 200; Mace and Bogardus, op. cit., pp. 136 ff.; Channing, op. cit., pp. 155-56, 165, 191-92; Hart, School History of the United States, p. 137; Thompson, History of the People of the United States, p. 154; Stephenson, op. cit., p. 190; Gordy, Stories of Later American History, pp. 78 ff.; Guitteau, op. cit., pp. 192-93; McLaughlin, 
for elementary use, although it appears in some of the textbooks for the high school. ${ }^{72}$

Benedict Arnold and Charles Lee are held up to the pupils as examples of the basest and most dishonest of humankind. ${ }^{73}$ Their characters, as depicted, stand out in sharp contrast to the heroic figures commonly met.

Of those other personages of these early days appearing frequently upon the pages of the histories are Captain John Smith, Roger Williams, William Penn, John Winthrop, Robert Morris, Benjamin Franklin, Hamilton, Otis, Dickinson, Madison, and Jefferson. ${ }^{74}$ In many cases groups of men engaged in a specific task or bound together by some common tie receive the praise often accorded individuals. ${ }^{75}$

op. cit., p. 170; McMaster, School History of the United States, pp. 148-49; Thwaites and Kendall, op. cit., 186-87; Fite, History of the United States, pp. 146 ff.; Forman, op. cit., p. 145; Gordy, History of the United States, pp. 142 ff.; Mace, School History of the United States, pp. 185-86; Tappan, American Hero Stories, pp. 151-58, $179 \mathrm{ff}$.

${ }^{72}$ Daffan, op. cit.; Tappan, op. cit., pp. 143-51; Hart, Nere American History, p. 135; Muzzey, op. cit., p. 103. See part of the study devoted to England.

${ }^{73}$ Barnes, Short American History for Grades, p. 60; Woodburn and Moran, op. cit., p. 154; Elson, op. cit., pp. 164-65; Fite, History of the United States, p. 150; Hart, Nere American History, p. 147; Barnes, American History for Grammar Grades, p. 218; Fite, The United States, pp. 164-65.

${ }^{74}$ Hart, New American History, p. 45; Eggleston, First Book in American History, pp. 29, 130 ff.; Stephenson, op. cit., pp. 80-82; Muzzey, op. cit., pp. 43-44, 54; Forman, op. cit., pp. 223, 41, 54, 177; Bourne and Benton, History of the United States, pp. 163-64; Elson, op. cit., pp. 253-55, 271-72, 197, 268; Leonard and Jacobs, The Nation's History, pp. 166, 201-2; Beard, op. cit., pp. 145-46; Latané, op. cit., p. 120; Channing, op. cit., pp. 50-51, 205-6; Channing, A Students' History of the United States, p. 61; Coe, Founders of Our Country; Halleck and Frantz, op. cit., p. 388; Mace and Bogardus, op. cit., pp. 178-79, 187-88; Garner and Henson, op. cit., p. 250; Barnes, op. cit., p. 247; Thompson, First Book in United States History, p. 244; Hart, School History of the United States, pp. 190-91; Halleck, op. cit., pp. 244-45; Horne, op. cit., II, 58, 44; Evans, op. cit., pp. 248-51; Gordy, Stories of Later American History; Woodburn and Moran, op. cit., p. 173.

${ }^{75}$ Such as the signers of the Declaration of Independence or a group of people like the Pilgrims and Puritans. 
Following the Colonial and Revolutionary periods and passing into that of nationality, aside from those mentioned in the preceding list, one meets frequently the names of Boone, Lewis and Clark, James Robertson, Sam Houston, and John C. Fremont, those pioneers of expansion, some of whom carried on their activities in the periods first treated..$^{76}$ J. Q. Adams, Monroe, John Marshall, Jackson, Clay, Webster, and Calhoun are given considerable attention in the period before the fifties, Jackson undoubtedly receiving the greatest amount of space. The heroes of the War of 1812 and those of the Mexican War are mentioned elsewhere in this study. Garrison, Douglas, John Brown, Davis, and Seward, besides the presidents, are accorded attention in most histories. Lincoln and the military heroes of the Civil War, particularly Grant and Lee, are found appearing most often in the period of the Civil War. In our more recent history, Dewey and Pershing are outstanding military heroes, whereas, among civilian leaders of various interests, there is an occasional mention of Edison, John Hay, Elihu Root, and Gifford Pinchot. Roosevelt and Wilson, Cleveland and McKinley are the outstanding presidents so far as attention in the textbooks is concerned. Other persons, of course, are mentioned, but not by all histories. Nor are these persons named the only significant personages. They are those whose contributions receive the most space or the most eulogy, taking, in the mass, the histories reviewed. Men whose work has been that of the chief executive are mentioned in all books.

The qualities most often held worthy of emulation are those of service to country, either by defending it in time of war or by offering some constructive idea as to the settlement of difficulties, the formulation of political concepts into a political faith for the people, and unusual leadership in statecraft. Washington may typify the first; Wilson, the second; Jefferson, the third; and Roosevelt, the fourth.

Assuming that the heroic characters most frequently introduced into the great majority of histories are those held to have

${ }^{76}$ See, for example, Gordy, Stories of Later American History; Fish, op. cit.; Daffan, op. cit.; Mace, Primary History of the United States. 
made the highest contribution to the country's history, pupils can readily gather that the greatest patriots are the military forces of the country and the leaders of political thought and action. This same point of view can be gained from a passage such as the following, taken from a textbook for the grades which assures readers that "loyalty and cheerful willingness to serve one's country is the duty of all who are within the limits of military age."

An assertion such as this, abetted by the use of colorful and eulogistic adjectives describing the exploits and achievements of heroic characters set in this frame, can easily establish definite concepts. Although some of our histories speak of war as "a cruel thing at best"78 and urge the settlement of differences between nations by peaceful means, ${ }^{79}$ yet other books are at times advocates of preparedness, declaring that lack of it prolongs a war. ${ }^{80}$ West, for example, points out that "the cost of war is measured first of all in human lives; then in money and property destroyed. The bitterest cost cannot be measured. It is paid in the bad habits formed during long years in camp and barracks and on the battlefield and in the spirit of fear and vengeance which follows war." 81

On the other hand, according to Stephenson,

We study the wars in which our country has been engaged, first, because the courage and self-sacrifice of our ancestors serve to in-

$"$ Barnes, Short American History, p. 372.

${ }^{78}$ Evans, op. cit., p. 405. See also Barnes, American History for Grammar Grades, p. 172; Thompson, First Book in United States History, p. 399.

${ }^{79}$ Ibid. See also Halleck, op. cit., p. 269; Elson, op. cit., p. 289; Barnes, Short American History for Grades, p. 328; Stephenson, op. cit., pp. 422-23; Garner and Henson, op. cit., p. 461; Thwaites and Kendall, op. cit., p. 552; Gordy, History of the United States, pp. $420 \mathrm{ff}$.; Mace and Bogardus, op. cit., p. 384; Guitteau, op. cit., pp. 543-44; Thompson, History of the People of the United States, p. 419.

${ }^{80}$ Thwaites and Kendall, op. cit., p. 578; Fish, op. cit., p. 475; Guitteau, op. cit., p. 485; Long, op. cit., p. 438; Burnham, The Making of Our Country, pp. 243, 248; Horne, op. cit., II, 86, 88, 96, 371; Muzzey, op. cit., p. 434; Channing, A Students' History of the United States, p. 562; West, History of the American Peóple, p. 636; O'Hara, A History of the United States, p. 225; Bourne and Benton, American History, p. 610.

${ }^{81}$ West, The Story of Our Country, p. 395. The italics are in the original. 
spire us with a like devotion to duty, even, if need be, to the laying down of our lives; and second, because they are precious lessons in how to defend ourselves. ${ }^{82}$

It has been mentioned elsewhere in this study that from a reading of the textbooks a child would gather the impression of the invincibility of the American forces in all struggles in which they have been engaged, and that a pupil could readily conclude from his study that the American soldier and sailor are not only more valorous but more generous than their foes. This impression is easily gained when adjectives, commonly used in connection with wars, as well as other forms of speech, are considered. Adjectives such as glorious, brave, brilliant, strong, unconquerable, notable, and imperishable are frequently employed. Such statements as the following, taken at random from two histories, are cited merely to show how the phraseology of discussions is such as to inspire reverence in the pupils for the warlike undertakings of the United States:

Next came the order to the Marine Brigade to capture Belleau Wood; and in the fight that followed, American marines proved themselves the equal of the British at Ypres, of the Canadians at Mons, of the French themselves at Verdun .... the German defenders outnumbered our men by at least three or four to one. But the marines never faltered (Guitteau, Our United States, p. 603).

A few American vessels [in War of 1812], too weak to meet the enemy, were hidden in a sheltered harbor protected by land batteries. Suddenly appeared Oliver Perry, a young naval officer, with orders quickly to build enough ships to beat the British. His timber was then growing on the shore. He had asked for that job, had even sought it eagerly, because it is a tradition of the American navy to challenge the impossible.

With incredible energy Perry built a 'squadron, launched it, and gave battle at Put-in-Bay. The British had six ships mounting 63 guns, the Americans nine with a total of 54 guns. A terrific fight it was, abounding in heroic incidents; the end was told in Perry's dispatch "We have met the enemy and they are ours,-two ships, two brigs, one schooner, one sloop." That is the only squadron that in the whole history of the British navy ever surrendered (Long; America, p. 264).

${ }^{\mathrm{s} 2}$ Stephenson, op. cit., p. 176. See p. 28, where this is previously quoted. 
Recently this point of view was attacked by a member of the United States army, Lieutenant Colonel Thomas J. Dickson, at the annual convention of the Military Order of the World War. Colonel Dickson at that time issued a Critique on American School Histories, in which he criticized fifty-two American school textbooks for "serious errors of omission and commission," and declared that "some of these school histories are ridiculous, absurd and stupid!"83 According to Colonel Dickson, "unless our histories are immediately corrected, our pretensions, unwitting or otherwise, doom us to become the laughing stock of the world and endanger the peace of the nation." 84 He holds this to be true because of an unfortunate use of military terms by persons lacking knowledge of their correct use, because of inaccurate statements regarding military events in the World War, because of the omission of certain significant military maneuvers, and because of false impressions as to the unvarying success of American forces.

In regard to this last point, Colonel Dickson quotes as follows from Mace and Bogardus' History of the United States:

There (San Mihiel) 500,000 Americans met the best troops Germany had, captured 16,000 and went smashing through their lines. .... Over a million men in khaki fought like heroes for over a month. They drove the Germans reeling back toward the Rhine. ${ }^{85}$

Colonel Dickson exclaims :

"Reeling back toward the Rhine!" The Germans contested every foot of ground from the Vauquois Mountain to Sedan. They made a masterful retreat. If the period of "reeling" covers time from turn of the tide to Armistice; they killed 44,000 American soldiers during this time. For weeks, while moving on Sedan, our battle deaths averaged 1,000 soldiers a day. Our soldiers did not wear khaki. We drove the enemy back; captured their trenches, but did not go "smashing through their lines." 86

${ }^{83}$ Thomas J. Dickson, Critique on American School Histories, New York; (Military Order of the World War, 1926). "Authors are advised not to attempt to use this critique in correcting school histories" is' a statement on the first page of the pamphlet.

${ }^{84}$ Ibid., p. 1.

${ }^{85}$ Ibid., p. 8. See Mace and Bogardus, op. cit., pp. 477-78. ${ }^{86}$ Ibid. 
From another textbook he quotes the following:

The fighting at Belleau Wood, Chateau Thierry and in the Argonne Forest demonstrated that the American soldier with six months of training is more than a match for the German veteran. Lack of training on the part of our troops was overcome in large measure by native ingenuity, courage and skill.

To this, Colonel Dickson says:

Steady Clio! "By pride angels have fallen ere thy time." Q.E.D. Ideas like these when believed by children make work for the Graves Registration Service. As a veteran of three wars I have seen the flower of America fade three times and enough money spent to pave with concrete every road in the United States. Same old story. Unprepared $!^{87}$

Of the school histories analyzed for this study, Colonel Dickson criticizes Thompson's History of the People of the United States, Woodburn and Moran's Elementary American History and Government, Estill's Beginner's History of Our Country, Gordy's History of the United States, Daffan's History of the United States, Long's America, Hall, Smither, and Ousley's A History of the United States, Horne's The Story of Our American People, Forman's Advanced American History, Fish's History of America, Mace and Bogardus' History of the United States, Bourne and Benton's American History, Halleck's History of Our Country, Guitteau's Our United States, Burnham's The Making of Our Country, and Fite's History of the United States.

But each nation engages in self-praise and asserts its superiority to other peoples in all lines of endeavor. Above all, the United States, like other nations, ascribes peaceful inclinations to itself and denies any militaristic tendency. ${ }^{88}$ "Always a peace-loving nation," declare Garner and Henson, "the United

${ }^{87}$ Ibid., p. 10. The quotation is from Guitteau, op. cit., pp. 595-96.

${ }^{88}$ See Jonathan French Scott, The Menace of Nationalism in Education (New York, 1926). This is a study of a few textbooks in European countries. 
States has not imitated the European powers by keeping a large standing army or requiring compulsory military service." 989

So far as a feeling of superiority over other peoples is concerned, the Baker-Thorndike Seventh Reader explains it in this way:

Every country is inclined to look with pride on its own especial achievements and often to think of them as greater than they really are. We Americans have been called boastful; and it must be admitted that, in our satisfaction with what we have done, we have often overlooked the big deeds of other nations. Still, it may easily be shown that we have played a big part in developing the civilization of our own time. Our representative system is the oldest in the world, and, no country has more safety, more freedom, more opportunities for its people. We have won the good will of other nations by fair and generous dealing with them. Our sense of the nation's honor does not lie in settling our heels on the necks of other people; we think it more honorable to treat them fairly..... We have grown rich, but we have been generous with our wealth. .... In operations that require courage, energy and big planning, America has a fine record. . . . . ${ }^{90}$

Just what the reactions are to such narratives possibly cannot be measured to any accurate degree. However, to determine the meaning of such abstractions as patriotism and loyalty to children, the following questions were asked of 1,125 children ranging from the seventh grade through the senior year of high school: "What is patriotism?" "How can you show your loyalty to your country?" "Have you, through a study of history, gained a liking or a dislike for any country?"

The questions were asked children in schools of the states of Pennsylvania and Iowa, commonwealths of distinctly different interests. The average age of the seventh grade was twelve years; of the eighth, thirteen years; of the ninth, fourteen years; of the

${ }^{80}$ Garner and Henson, op. cit., p. 631. See also Mace and Bogardus, op. cit., p. 475; Guitteau, op. cit., pp. 571-72; West, The Story of Our Country, p. 472; Thompson, History of the People of the United States, pp. 502-3.

${ }^{90}$ This citation properly falls in the section devoted to readers, but is used here to illustrate the point raised. 
tenth, fifteen years; of the eleventh, sixteen years, and of the twelfth, seventeen years.

Since patriotism and loyalty seemed synonymous to the pupils, the first question is not considered to any extent. The answers fall into these general categories: Defense of country or service to one's country in time of war and honoring the flag, obedience to the law, voting, celebrating national holidays, and honoring "patriotic" men and officials, and paying taxes. In addition, many $y_{1}$ answers of an individualistic nature came, such as "keeping healthy," "serving on the jury," "being loyal to one's fellowmen," "objecting to the formation of secret organizations seeking to destroy the government," "not speaking against your own government," and "making others respect the United States." Defense of country and service to one's homeland, obedience to the law, and voting appear the most often, with "honoring officials" and "paying taxes" following.

Defense of country, since it is found most often, is made to represent 100 per cent. The comparative percentages will show how other "duties" are rated in the minds of the 1,125 children.

Defense of country $\ldots \ldots \ldots$
Obedience to law $\begin{gathered}\text { PER CENT } \\ \text { Voting }\end{gathered}$

In other words, defense of country appears approximately nine times more than the duty to exercise the suffrage, and twenty-five more times than paying taxes. Those holding "obedience to law" the first attribute of loyalty to country are not far behind the number believing defense of country and honor owed to the country's flag the sine qua non of patriotism.

It may not be inappropriate to repeat what one senior in one of the better schools of Iowa holds to be patriotism:

Patriotism is a great thing. It means much to us. If you are loyal you are really in a way patriotic to your country. Loyalty and patriotism are very close relatives. One cannot very well live without the other. Respect your flag and all legal holidays. It may be that 
many people do not fully realize the significance of the Armistice. The world was at war, and then it became more peaceful. The nations were put at rest. Just think of the lives that were sacrificed for us. We should honor our soldier boys and sailors and marines. Think what they did for us; the hardships they went through. On any Patriotic Holiday just stop and think who and what has been sacrificed for us.

Other answers such as the following are typical:

"One can show there [sic] love or loyalty to there [sic] country by respecting the laws or the constitution, by raising [sic] when the national anthem is being sung, by being ready to go to war if at any time they may be called. Always having in mind the good one can do in time of war-both men and women."

"Patriotism is the manner in which you support your country by abiding with its laws and always being ready to preserve, protect and defend it. Patriotism even goes so far as to be ready to die loyally [sic] for your country.",92

The influences of the World War still are present if one judge by the answer of a Pennsylvania girl of sixteen, who says: "You can show your loyalty to your country by helping it in time of need. This does not mean that you must take arms and fight, but does mean that you support the government and the army. This could easily be done in the World War by securing liberty loans."

In the replies received to the question as to whether they had gained a liking or a dislike for any country through historical study, the pupils expressed themselves, in a few cases, as not believing that their animosities had been engendered by instruction in this subject. Some pointed out that history should teach that "there is good in every nation," five pupils writing that history should aid pupils "to see both sides to a national or international question." One child declared that "history fosters a love of your own country," another expressing the same thought held, however, that "love of one's native land is natural"-a belief with which few would quarrel. One boy pointed out that "there school.

${ }^{91}$ Written by a Pennsylvania girl, seventeen years old, junior in high

${ }^{92}$ Written by a Pennsylvania boy, fifteen years of age, in the tenth grade. 
is good in every nation," and one girl indicated her attitude toward Germany thus :

Through my study of history I have to a certain extent overcome a hatred for Germany. By studying history and in this manner learning Germany's side of the question it has reconciled me to a certain extent to think that Germany is not as black as she was painted by the nations engaged in the World War. I realize that she was greety [sic] but all nations have their good and bad points and we must look up to her for her splendid organization [sic] and training. ${ }^{93}$

Yet most of the pupils expressed an admiration for, or a hostility toward, different countries. Austria received no favorable comments, whereas Belgium stands in sharp contrast to the hostility expressed toward Austria characterized as "one of the countries which made the World War." Approximately the same number liked England as those who did not, the reasons for approval arising from the fact that she has "good type of citizens," "great statesmen," and is "the mother country of America." Those stating their dislike for England, when giving reasons, asserted that she "wanted to stop American growth," that she is a "selfish" and "overbearing" nation, and "grasps at something not belonging to them," that she is "unwilling to give the United States credit for her part in the World War," and because of "her treatment of the thirteen colonies."

Over eight times as many students avowed their liking and admiration for France as those confessing an unfriendly attitude. In the latter case the feeling arose, when a reason was given, from a "hatred of Napoleon" and because France had been "intolerant" in religious matters. On the other hand, France is liked because the French are "a peaceful, courageous, patriotic people," because "they helped the United States when in danger," because they have fine architecture and an appreciation of the arts, and because they "like the United States."

Germany presents about the same ratio as France, only in reverse order. As one might expect, dislike for Germany has been engendered by the fact that she "brought about the World War,"

${ }^{23}$ Written by a girl, a junior in high school in Pennsylvania, age seventeen. 
because of her "treatment of Belgium," "her cruelty to women and children," because she is "against world peace," because she "killed American Buddies," because "she is not trustworthy," and because she is "a shelter of barbarism." The students expressing an admiration for Germany, when stating their reasons, declared that the German people were not responsible for all the government did, for "the people were under a tyranny," and that, in some cases, our "dislikes are based on unsound suspicions." Admiration was also expressed for Germany's ability at organization.

Few pupils expressed a liking or admiration for Mexico, Russia, or Turkey. Holland, Switzerland, South America, and Canada are generally "liked," in the last two cases commercial contacts being mentioned as desirable. Spain, Japan, China, Greece, and Italy are held about equal, so far as preferences or expressions of disapproval are concerned. In a few cases, "liking" was mentioned for the countries of Holland, Norway and Sweden, Poland, and Ireland.

A liking for their own country was attested to by many because there is "more freedom here" than elsewhere; there are "better morals in this country"; we have a "better government," "better schools," and "better churches"; because of "the battles fought and won"; because "we help other countries"; because of "the honesty and truth of the United States in the World War"; because we are a "peaceful" people, and "always have done the right thing"; "the best country of all"; and because "America started so small and grew so large and great." Only four pupils out of the entire number confessed that the United States "has carried on some enterprises which we can't be proud of." One other pupil objected to the attitude during Washington's administration taken toward France in "a time of need." A few others suggested indirectly that all nations are subject to changes in policy, and that the United States may not be immune from this immutable law.

In summarizing the attitudes which may be acquired from reading the history textbooks and which are obviously generally 
subscribed to, the following quotation is given as setting forth a commonly accepted fact.

Every American feels a just pride in the achievement of our country. Beginning with a little straggling group of states along the Atlantic seaboard, we have pushed on step by step conquering and civilizing the wilderness as we went until we reached our ocean boundaries on the west, and then reached out to the islands of the sea. From a little weak federation of states we have built up a strong nation of united section [s] bound together by common interests, common ideals and a common patriotism. Finally, we have developed into one of the foremost powers of the world. We have made a nation of many races, and these have been blended together into one type, the vigorous, aggressive, resourceful American. The very cornerstone of American liberty and government is a belief in the rule of the people, and with the growth of territory has gone the spread and development of democracy. . . . . Our political ideals we have passed on to other nations, and we have fought a war to make the world safe for the democracy which we have created and to aid the oppressed peoples of the earth.....

To this end [a continuation of American principles] we [the authors of the textbook] appeal to the courageous patriotism of the student readers of this history soon to come into responsible citizenship, and upon them we invoke the guidance and blessing of the God of our fathers.

I love thine inland seas,

Thy groves and giant trees,

Thy rolling plains;

Thy rivers mighty sweep,

Thy mystic cañons deep,

Thy mountains wild and steep,

All thy domains.

Thy silver eastern strands,

Thy Golden Gate that stands

Afront the west;

Thy flowery Southland fair,

Thy sweet and crystal air-

O Land beyond compare,

I love thee best. ${ }^{94}$

${ }^{94}$ Hall, Smither, and Ousley, op. cit., pp. 524-25. 


\section{CHAPTER XIII}

\section{INTERNATIONAL ATTITUDES IN SOME EUROPEAN HISTORY TEXTBOOKS}

Not only do textbooks in American history contain statements which will form opinions as to the achievements of different nations and peoples, but textbooks in European history carry information of a similar nature.

To determine the general characterizations found in European histories, four books were selected for analysis: Hayes and Moon's Modern History, West's World Progress, Elson's Modern Times and the Living Past, and McNeal's Modern Europe and Its Beginnings. The last book was chosen because it has but recently come from the press, the others are found frequently in approved lists. Discussions relating to events beginning approximately with the eighteenth century and continuing to the present form the basis of comparisons. Obviously most of the material deals with European conditions and events, not much attention being directed toward affairs purely American. To be comprehensive, the part of the study dealing with this aspect of the subject doubtless should have included more books, but it is hoped that the histories selected contain typical material representing the most recent points of view.

There is little criticism of American policy as it relates to our dealings with other nations, the authors usually leaving the impression that American achievements and American intercourse with other powers are praiseworthy. West, in World Progress, however, essays to question the American attitude in the War of 1812, and ventures to criticize American politics in 1920, the latter being quite colorless. ${ }^{1}$

Austria, on the whole, is not described in a way to inculcate in the pupil a favorable attitude toward that country. It is ${ }^{1}$ West, World Progress, pp. 441, 661. 
made a country addicted to repressive measures, a country lacking in democratic ideals, and the home of the autocratic and merciless Metternich. In 1756, it is said for example, that "Austria began a war of revenge." The reader of Elson is informed:

The Italian rebellion against tyranny began in Sicily and Naples in January, 1848, even before the revolution in France. The imbecile tyrant on the throne was quickly frightened into granting a constitution. Then came the news of the revolt in France and the flight of the hated Metternich from Vienna. Instantly the whole Italian peninsula was aflame with revolution. Venice and Lombardy expelled the Austrian garrisons and declared for independence. Their oppression had been galling. Austrian spies and secret police were everywhere. Political discussion was forbidden. There was a tax on every bakery and every market. Venice and Lombardy constituted but one eighth of the population of the Austrian Empire, but paid one fourth of the taxes. Calling on the rest of Italy for help, they were joined by Charles Albert, king of Sardinia ..... It was a great national uprising for liberty. Everything seemed to promise a steady release from Austrian tyranny. ....

The report that Metternich had fallen caused a wave of rejoicing over Germany, for the Germans also were the victims of his heavy hand. .... . ${ }^{3}$

Metternich and the Austrians are pictured by Hayes and Moon also as exemplars of autocracy. In speaking of the Quadruple Alliance, they assert that "the world was to be made safe for autocracy and Austria. There was to be peace without liberty."4 In the treaties of 1815, both Austria and Prussia are described by McNeal as opposed to popular movements for liberal government as well as to nationalist impulses among the German and Italian peoples. ${ }^{5}$ Adjectives such as "repressive," as applied to Austria's measures, tend to give the same impression. ${ }^{6}$ Her ambitions for an expansion of territory are set forth in discussions such as those relating to the Balkan countries. ${ }^{7}$

${ }^{2}$ Ibid., p. 398.

${ }^{3}$ Elson, Modern Times and the Living Past, pp. 542-43.

${ }^{4}$ Hayes and Moon, Modern History, p. 435.

' McNeal, Modern Europe and Its Beginnings, p. 293.

- Ibid., p. 297.

Ibid., p. 345. 
It is a commonplace that Austria is made to share no small responsibility for the World War. ${ }^{8}$

Germany fares scarcely better than Austria. Such terms as "Prussianizing" and "Prussianization" carry significant connotations. "Die Wacht am Rhein" and "Deutschland über Alles" still bring to the readers' mind much of the World War propaganda. ${ }^{9}$ Militarism and Bismarckian methods do not fail of attention, nor is Prussia cleared of charges of perfidy and unfounded claims to territory. ${ }^{10}$ And surely there can be no doubt in the pupil's mind, after a perusal of textbooks in history, as to Germany's guilt in the World War. ${ }^{11}$

Hayes and Moon, however, in their discussion declare:

Because the diplomatic negotiations leading to the war had been conducted in secrecy, no one at the beginning knew for certain who were the guilty nations. The Germans and Austrians blamed Russia and England. The Allies blamed the German Emperor. As a rule, the common people in each country were willing to believe that their own government was innocent and their enemies guilty. Later on many of the facts were revealed and the evidence showed that the Austrian Government, with German consent, deliberately planned to crush Serbia; but it still remained doubtful whether they desired to start a war among the Great Powers. It was also shown that some of the Russian military leaders did their best to bring about the war. The whole truth is not yet known and probably will not be known for many years to come. ${ }^{12}$

Yet as a foe to world-peace, Germany is shown as holding an "implacable opposition" due to her militarism. ${ }^{13}$ Her methods of carrying on war likewise receive denunciation, poisonous gas, for example, being described as "a devilish device," and the use of the submarine as a token of "German frightfulness." As

${ }^{8}$ Ibid., p. 391. Other textbooks would hold the same point of view.

${ }^{9}$ Ibid., pp. 295, 296.

${ }^{10}$ McNeal, op. cit., pp. 309, 310; West, op. cit., pp. 451, 504, 566, 567; Elson, op. cit., pp. 554, 575, 649; Hayes and Moon, op. cit., pp. 204, 205, 211, $480,538,542,547$.

${ }^{11}$ Elson, op. cit., p. 650; McNeal, op. cit., p. 391; West, op. cit., p. 629.

${ }^{12}$ Hayes and Moon, op. cit., p. 717. ${ }^{13}$ West, op. cit., pp. 619, 626, 629. 14 Ibid., pp. 633, 636; McNeal, op. cit., p. 398; Elson, op. cit., pp. 673, 675. 
for the traditional treatment of the violation of Belgium's neutrality, there is still evidence of its popularity among textbook writers. ${ }^{15}$

France, moreover, is not so consistently apotheosized as in American histories, for Napoleon is given considerable attention, and his methods are not more favorably dealt with than are those of Metternich and Bismarck. ${ }^{16}$ Yet the picture drawn of France's activities from the eighteenth century to the present is not so gory as that of her neighbor at the east, and the reader is told that "French culture and French civilization have remained to our own day the standards of culture and civilization of Europe, even of the world."17

In regard to Russia, there is little to commend to the pupils reading these textbooks, unless a feeling of sympathy kindled for the lower classes can do so. A "barbarous, brutal despotism,"18 backward in cultural progress and in industry, ${ }^{19}$ czarist Russia is left accused of "tyranny," of being devoid of liberalism, ${ }^{21}$ and of ambitious designs on territory not legally hers. ${ }^{22}$ Russia's influence in causing a World War in 1914 is noted by McNeal and Hayes and Moon. Bolshevist Russia is described as having a government resting upon "confiscation, terror and dictatorship of the lower classes," brought about by "violence and bloodshed, and the disorganization of industry and decline in production.".23

Turkey fares no better, for the "unspeakable Turk" is characterized as "fanatical," "cruel and oppressive."24 His "reduction to impotence," according to Elson, "must be pronounced "one of the most gratifying results of the World War.",

${ }^{15}$ Elson, op. cit., p. 653; West, op. cit., p. 629; Hayes and Moon, op. cit., pp. 716, 722; McNeal, op. cit., p. 395.

${ }^{16}$ Elson, op. cit., pp. 484, 485; West, op. cit., p. 449; McNeal, op. cit., p. 245.

${ }^{17}$ Hayes and Moon, op. cit., p. 465.

${ }^{18}$ Ibid., p. 180.

${ }^{21}$ West, op. cit., p. 589.

${ }^{19}$ Ibid., pp. 178, 179.

${ }^{20}$ Elson, op. cit., p. 459.

${ }^{22}$ McNeal, op. cit., p. 345.

${ }^{23} \mathrm{Ibid}$., p. 417.

${ }^{24}$ McNeal, op. cit., p. 349; West, op. cit., p. 568; Elson, op. cit., pp. 619, 621; Hayes and Moon, op. cit., pp. 554, 676.

${ }^{25}$ Elson, op. cit., p. 719. 
England is not accorded the place of archtraitor to democratic principles which she appears to hold in some American histories. Rather she is described as that exponent of democracy who successfully opposed Napoleon, ${ }^{26}$ and who came "to be regarded all over the civilized world as the most liberal and progressive of nations." 27 Yet she is pictured as doing her "utmost to stamp out Irish nationalism,",28 although her colonial government is generally conceded wise in conduct and of benefit to her colonists. ${ }^{29}$ Attributes of kindness and generosity to smaller nations $^{30}$ stand in contrast to those qualities which are ascribed by writers to her in her imperialistic adventures. ${ }^{31}$ As the ally of the United States in the World War, her "superb navy" and "heroic army" struggled with American forces in the "war for democracy." Naturally the events chronicled in these textbooks take on a different color for the American school pupil than those discussed in United States histories, for they are often remote from his experience. Events in American histories involving Anglo-American contacts naturally touch, for the most part, upon incidents close to American patriotic sentiment and involve matters of a controversial nature in which the United States has been a participant.

${ }^{26}$ West, op. cit., p. 449.

${ }^{27}$ Hayes and Moon, op. cit., pp. 264, 266; Elson, op. cit., p. 518.

${ }^{28}$ Hayes and Moon, op. cit., p. 638.

${ }^{29}$ Elson, op. cit., pp. 429, 593, 600; West, op. cit., p. 537.

${ }^{30}$ Ibid., p. $568 . \quad \quad{ }^{31}$ Ibid., p. $608 . \quad{ }^{32}$ Ibid., p. 632. 



\section{PART II}

TEXTBOOKS IN CIVICS, IN SOCIOLOGY, IN ECONOMIC AND POLITICAL PROBLEMS 



\section{CHAPTER XIV}

\section{THE AMERICAN CITIZEN: HIS RIGHTS AND DUTIES}

The American of today is conscious that his natal heritage includes certain well-known and prescribed political ideas through which a form of government has been evolved that offers to him protection of life, liberty, and property. Within this consciousness he also holds the instruction of his tender years which taught him an avalanche of responsibilities and duties as a fair return for the protection given. Not only do history textbooks teach this, but even more so do books on government. The whole subject of government in the schools is charged with the duties and responsibilities of citizenship.

"A citizen," declare Woodburn and Moran, "is a member of the nation who owes the nation allegiance and is entitled to its protection."1 Citizenship as held by Americans therefore "implies membership in a nation," according to Williamson. "A citizen owes allegiance to his government, and in return is entitled to the fundamental advantages of organized government, such as the protection of life, liberty and property at home and abroad."' Yet "citizenship does not consist merely of boasting or receiving benefits; it calls for accepting responsibility and for service to one's fellow men. . . . . It not only brings privileges, but carries obligations," says Hughes. ${ }^{3}$

In the fulfilment of these obligations, Williamson avers,

much depends upon the extent to which each of us assumes the responsibilities of citizenship. Those who have gone before us conquered a wilderness, expanded and preserved the Union. But it is not for us complacently to accept the result. Much has been done,

${ }^{1}$ Woodburn and Moran, The Citizen and the Republic, p. 1.

${ }^{2}$ Williamson, Problems in American Democracy, p. 341. See also Ziegler and Jacquette, Our Community, p. 19.

${ }^{3}$ Hughes, Nerw Community Civics, pp. 269, 281. See also Gettell, The Constitution of the United States, p. 76. 
but more remains to be done. .... Without a high sense of personal responsibility, coupled with an intelligent and consistent effort, we can never reach the high goal admittedly possible. ${ }^{4}$

In order to attain "the high goal" desired, pupils are admonished to "study their own government that they may be as well informed as the children of foreign nations," that they may know "its strength .... to support it, and that they should know its weakness that they may be able to strengthen it," in order that "it may continue to be the greatest government in the world."

"It is the duty of every good citizen to know his country's history, to honor its flag, and to be true to its ideals," declare Munro and Ozanne. ${ }^{6}$ "The citizen who does not know his country's past cannot properly understand its present nor can he properly contribute to its future."

The boon and virtues of citizenship are, therefore, envisaged for the boy and girl as the highest possible attainment. "Citizenship," say Jenks and Smith, "is the highest and greatest gift of the nation." It is "one dignity to which every boy and girl is born, and which remains a life-long possession." The "greatest thing that any man can say is, that he is a citizen of the United States."9

The blessings of citizenship in the United States have been brought about, according to the textbooks, through organized government, whose purpose is "to promote the interests of each by promoting the interests of all."10 In other words, "government . . . . is our agent" in the advancement of "the safety and happiness of the people."12 Furthermore, government, it is said, is not a voluntary organization, but it has grown out of the

${ }^{4}$ Williamson, op. cit., p. 40.

${ }^{\circ}$ Brooks, Our Dual Government, pp. 17-18.

${ }^{6}$ Munro and Ozanne, Social Civics, p. 83. See also Guitteau, Preparing for Citizenship, p. 229.

${ }^{7}$ Munro, Current Problems in Citizenship, p. 72.

${ }^{8}$ Jenks and Smith, We and Our Government, p. 77.

${ }^{9}$ Guitteau, op. cit., p. 13.

${ }^{10}$ Munro and Ozanne, op. cit., p. 70.

${ }^{11} \mathrm{Jenks}$ and Smith, op. cit., p. 18.

${ }^{12}$ Munro, op. cit., p. 50. 
necessities of everyday life and brings all within its scope under its control. ${ }^{13}$ Its purpose is primarily protecting "the whole body of its people against external aggression, against foreign invasion," as well as "maintaining the rights and liberties of its citizens," not only from foreign interference but from "injustice at the hands of one another."14 This is accomplished, authors say, by laws "which define the relations of individuals to one another, and of one group of individuals to other groups."15 The purpose of laws then, is "to bring about fair play for all, to keep people from doing things that interfere with the rights of others."16 although such restraint may mean restrictions upon the freedom of individuals. ${ }^{17}$

Back of the laws, under which we carry on our customary and daily tasks, is the Constitution of the United States, the pupil is told. And this is the fundamental law of the land, the "most precious document to which Americans are heirs." 18 It is our "greatest charter of liberty." "Indeed, it might be called a charter of liberty for the world" is the opinion of Davis and McClure, who hold this view because "practically all civilized nations have adopted representative government modeled after

${ }^{13}$ Lapp, Our America, pp. 10, 38.

${ }^{14}$ Munro and Ozanne, op. cit., pp. 70-71. See also Long, Government and the People, pp. 2-3; Binford and Graff, The Young American Citizen, p. 28; Turkington, Community Civics, pp. 76-78; Finch, Everyday Civics, pp. 45-46; Hepner, The Good Citizen, p. 22; Hughes, op. cit., pp. 83-84; Magruder, American Government in 1923, p. 1; Levis, Citizenship, p. 425; Ziegler and Jacquette, op. cit., p. 40; Davis and McClure, Our Government, pp. 1-2, 240; Beard, American Citizenship, p. 5; Morgan, Living and Working Together, p. 155; Brooks, op. cit., pp. 35-37; Dunn, Community Civics for City Schools, pp. 41-48; Hughes, Text-Book in Citizenship, pp. 519, 527.

${ }^{15}$ Munro and Ozanne, op. cit., p. 71.

${ }^{16}$ Levis, op. cit., p. 359. See also Ziegler and Jacquette, op. cit., p. 50; Dunn, op. cit., p. 49.

${ }^{17}$ Reed, Loyal Citizenship, p. 4; Lansing and Jones, Government in State and Nation, p. 3; Guitteau, op. cit., p. 42; Jenks and Smith, op. cit., p. 17; Turkington, My Country, pp. 193, 195-96; Hepner, op. cit., pp. 24-25; Hughes, Text-Book in Citizenship, p. 582; Levis, op. cit., p. 119; Ames and Eldred, Community Civics, pp. 154-55, 232.

${ }^{18}$ Hayes, American Democracy, p. 89. See also Berry and Howe, Actual Democracy, p. 38. 
the American or English plan."19 Even statesmen of other countries have accorded it high praise, Gladstone being quoted as saying that "the American Constitution is the most wonderful work ever struck off at any one time by the mind and purpose of man," and Bryce having said that "it ranks above every other written constitution for the intrinsic excellence of its scheme; its adaptation to the circumstances of the people; the simplicity, brevity, and precision of its language; its judicious mixture of definition in principle with elasticity in details." 20 Indeed, as "the oldest written constitution or complete instrument of government in actual use," as well as ever today (although written in 1787), in what is truly a new world."22

The ideals expressed in the Constitution and insured thereby for the American people are those of freedom of speech, press, assembly, and petition, according to the textbooks. In addition to these rights are the privilege of trial by jury, no excessive bail, no excessive fines, no cruel punishments, no bill of attainder, no ex post facto law, the writ of habeas corpus, a speedy and public trial for accused persons; the provision that no person is twice in jeopardy for the same offense, and that homes are free from search and seizure except by a legal process, the same process being necessary for arrest, and the right of property. ${ }^{23}$

${ }^{10}$ Davis and McClure, op. cit., pp. 57, 67.

${ }^{20}$ Finch, op. cit., p. 199; Ames and Eldred, op. cit., p. 349.

${ }^{21}$ Jenks and Smith, op. cit., p. 51. Italics in the original. See also Beard, op. cit., p. 37 .

${ }^{22}$ Rexford and Carson, The Constitution of Our Country, pp. 1, 3-4.

${ }^{23}$ Woodburn and Moran, op. cit., pp. 389-96. See also Ames and Eldred, op. cit., p. 66; Forman, The American Democracy, pp. 86-89, 244-46; Lapp, op. cit., pp. 44-45; Hepner, op. cit., pp. 70-72; Munro, op. cit., p. 70; Lansing and Jones, op. cit., pp. 6-7; Rexford and Carson, op. cit., pp. 4-6; Hughes, Economic Civics, p. 326; Magruder, op. cit., pp. 206-13; Beard, op. cit., pp. 35-36, 64-76, 54-58; Munro and Ozanne, op. cit., pp. 581-82; Dunn, op. cit., pp. 391-93; Reed, op. cit., pp. 25, 66-68, 139; Berry and Howe, op. cit., p. 47; Greenan and Meredith, Everyday Problems of American Democracy, pp. 85, 10; Levis, op. cit., pp. 433-36; Gettell, op. cit., p. 60; Bennion, 
These rights, held fundamental to American liberty by the founders of the Constitution, are said to be the ideals upon which our government is based. In the polity of the American people, moreover, it is held are the "ideas of natural rights, popular sovereignty, right of resistance against tyranny, individual liberty, representative government and separation of powers."24 The Declaration of Independence, emphasizing the equality of all people, is believed by Woodburn and Moran to have re-created substantially the same ideals, many of which had been bequeathed to the colonists through English political documents such as the Magna Charta, the Bill of Rights, and the Petition of Right. ${ }^{25}$

One of the most significant of the political contributions made by the Declaration of Independence, according to authors of government textbooks, is the belief in the consent of the governed, a belief that no government should carry on its functions without the sanction of the people. ${ }^{26}$ In connection with the pronouncement of a faith in the ability of the people to govern themselves as announced by the colonial fathers, there is mention in some of the textbooks also of the theory of natural rights and of social contract. ${ }^{27}$

Several authors indicate the significance in American political theory of such documents as the Mayflower Compact and papers of the era of the Revolution, in building the foundation of later American political development. The Mayflower Com-

Citizenship, pp. 63-66; Ziegler and Jacquette, op. cit., pp. 51, 64; Hayes, op. cit., pp. 305-9; Morgan, op. cit., pp. 192, 34-35; Ashley, The Nere Civics, pp. 12-13, 134-38; Southworth, The Common Sense of the Constitution of the United States, pp. 91-93; Berry and Howe, op. cit., p. 63.

${ }^{24}$ Gettell, op. cit., p. 60.

${ }^{25}$ Woodburn and Moran, op. cit., pp. 386-88; Reed, op. cit., p. 9; Munro, op. cit., pp. 62-69; Finch, op. cit., pp. 184-86; Munro and Ozanne, op. cit., p. 323; Greenan and Meredith, op. cit., p. 3; Dunn, op. cit., p. 50; Lansing and Jones, op. cit., p. 31; Mavity, Responsible Citizenship, pp. 4-6; Lapp, op. cit., p. 156.

${ }^{28}$ Hayes, op. cit., p. 86; Munro, op. cit., p. 48, and others.

${ }^{27}$ Munro and Ozanne, op. cit., pp. 63-66; Munro, op. cit., pp. 61-62; Dole, The New American Citizen, pp. 123-24; Berry and Howe, op. cit., p. 32; Williamson, op. cit., p. 342; Greenan and Meredith, op. cit., p. 3. 
pact, according to Berry and Howe, affords "the first instance of a movement toward responsible self-government originating in America. It did not provide a form of government, but only pledged its signers to obey the government" ${ }^{28}$ Under the Compact, it is pointed out, was organized "a civil body politick,"29 designed to "our better ordering and preservation," through "just and equal laws" for "the general good."

Thus, "We the people," as expressed in the preamble of the Constitution, is said to be the keynote of our democratic system and to attest the evolution through which government has passed from early English attempts at establishing the people's rights to the Constitutional Convention..$^{31}$

A justification for investing the people with the power of governing themselves, according to Munro and Ozanne, "is that it insures, not necessarily the best government, or even good government; but the sort of government the people earn for themselves." In short, "it will reflect the intelligence, honesty, and patriotism of the governed." ${ }^{\prime 2}$ Yet by some authors democracy is not considered "suitable" to all peoples, for not all peoples have advanced to a high plane of civilization..$^{33}$ But the United States presents an example where self-government has been successful because of its federal and republican character. ${ }^{34}$

Since the ultimate success of government is spiritual, text-

${ }^{28}$ Berry and Howe, op. cit., p. 15. See also ibid., pp. 15, 24, for mention of other documents.

${ }^{29}$ Hill, Community Life and Civic Problems, p. 433.

${ }^{30}$ Rexford and Carson, op. cit., pp. 6-7.

${ }^{31}$ Ziegler and Jacquette, op. cit., pp. 16-17, 20, 180; Rexford and Carson, op. cit., frontispiece, also p. 63; Lansing and Jones, op. cit., p. 55; Greenan and Meredith, op. cit., p. 3; Levis, op. cit., pp. 426-27, 428, 369-70; Finch, op. cit., pp. 160-62; Hughes, Text-Book in Citizenship, pp. 17, 695, 708-9; Reed, op. cit., pp. 70-71; Dunn, op. cit., pp. 435-37.

${ }^{32}$ Munro and Ozanne, op. cit., p. 70.

${ }^{33}$ Greenan and Meredith, op. cit., pp. 3-4, 474-77, 5-67; Munro and Ozanne, op. cit., p. 70; Hughes, Economic Civics, p. 41.

${ }^{34}$ Forman, op. cit., pp. 4-6; Beard, op. cit., p. 83; Hart, Social Life and Institutions, pp. 19-20, 253; Hughes, Nero Community Civics, pp. 157-58, 168; Mavity, op. cit., pp. 56-57; Hepner, op. cit., p. 295; Ames and Eldred, op. cit., p. 349. 
books pay considerable attention to the necessity of an enlightened electorate, for "a sound education and a patriotic spirit are the twin foundations of good citizenship," government being "no better or no worse than the men and women who are responsible for it." 35 Thus "the essence of democracy is government by public opinion," and "the kind of work the government undertakes and the way in which it does its work depend, in the ordinary course of events almost entirely upon public opinion; that is, upon what people think about political matters." ${ }^{36}$

Therefore, it is shown to be necessary for the intelligent and educated voter to exercise the suffrage in order to insure the welfare of this country, for "the vote is the most powerful thing in a republic, because the voters choose the men who govern us." ${ }^{37}$ This method of selecting officials is deemed the best meth-

${ }^{35}$ Gettell, op. cit., p. 84. See also Davis and McClure, op. cit., pp. 188, 196-98; Munro, op. cit., p. 426; Ames and Eldred, op. cit., p. 36; Long, op. cit., pp. 255-56; Hill, op. cit., p. 53; Jenks and Smith, op. cit., pp. 120, 215; Ashley, op. cit., p. 269; Morgan, op. cit., p. 11; Dunn, op. cit., p. 131 ; Forman, op. cit., p. 371; Brooks, op. cit., p. 156; Hughes, Text-Book in Citizenship, pp. 34-35, 53, 124; Ziegler and Jacquette, op. cit., pp. 55-64; Gettell, op. cit., pp. 3-4; Williamson, op. cit., pp. 255-256; Greenan and Meredith, op. cit., p. 63; Hughes, Economic Civics, p. 168; Munro and Ozanne, op. cit., pp. 492-93; Hepner, op. cit., pp. 68-69; Lapp, op. cit., pp. 57-59, 92-93; Mavity, op. cit., p. 175; Guitteau, op. cit., pp. 58 ff.; Brooks, op. cit., p. 158; Turkington, Community Civics, p. 271; Finch, op. cit., p. 30.

${ }^{36}$ Beard, op. cit., pp. 37, 43, 287-88. See also Mavity, op. cit., p. 268; Ashley, op. cit., p. 63; Woodburn and Moran, op. cit., pp. 24-25; Williamson, op. cit., p. 399; Burch and Patterson, Problems of American Democracy, p. 87; Hill, op. cit., pp. 453, 19-22; Davis and McClure, op. cit., p. 190; Forman, op. cit., pp. 235-36; Jenks and Smith, op. cit., p. 117.

${ }^{37}$ Bryant, I Am an American, p. 18. See also Hughes, Nere Community. Civics, pp. 88, 187; Morehouse and Graham, American Problems, pp. 367, 522; Forman, First Lessons in Civics, p. 50; Guitteau, op. cit., pp. 19-20, 27-28, 39; Garner, Government in the United States, p. 390; Hughes, Economic Civics, pp. 54-55, 318, 321 ; Jenks and Smith, We and Our Government, pp. 118, 105, 100-101; Hepner, op. cit., pp. 319, 321; Cabot, A Course in Citizenship, pp. 206-8; Beard, op. cit., p. 7; Binford and Graff, op. cit., pp. 57-59; Finch, op. cit., pp. 200, 301; Greenan and Meredith, op. cit., pp. 10-11, 77; Ziegler and Jacquette, op. cit., pp. 21, 159; Forman, The American Democracy, pp. 11-12; Shepherd, The Boy's Own Book of Politics, p. 23; Munro, op. cit., p. 73; Williamson, op. cit., pp. 373-74; Ames and Eldred, op. cit., pp. 251-52, 338; Turkington, Community Civics, pp. 162 ff.; Mavity, 
od ever devised for choosing a governing body. In contrast, writers point out the hardships and disadvantages entailed in a method of revolution or force by which some South American countries are said to have named their officials. ${ }^{38}$

In turn, when officials are chosen to public office they have been honored with "a public trust," pupils are told. "The proffer of its opportunities to any man or woman is a high compliment. Election to public office is the highest honor a democratic community can bestow," declare Munro and Ozanne. ${ }^{39}$ And it is the duty of these officials to discharge their duties faithfully and well.

It is held highly important, too, that they be men of ability and honor. ${ }^{40}$ "Political bosses are bad," ${ }^{41}$ yet Americans are said to have "easy habits of mind," so that frequently men looked upon "as decent, law-abiding, intelligent citizens" condone votebuying and bribe-giving. ${ }^{42}$ To our officials, however, there should be a loyalty, declare some of the authors. ${ }^{43}$ Furthermore, the pupil is advised to prepare for officeholding, since that as well as voting is a duty. ${ }^{44} \mathrm{By}$ those authors discussing it, civil service is considered as most desirable in comparison with the "spoils system." 45

op. cit., pp. 66-67; Reed, op. cit., p. 68; Lapp, op. cit., p. 185; Dole, op. cit., pp. 80-81, 95-96, 160; Levis, op. cit., pp. 432, 428; Burch and Patterson, op. cit., p. 87; Gettell, op. cit., p. 135; Hayes, op. cit., pp. 309-11; Woodburn and Moran, op. cit., p. 12.

${ }^{38}$ Shepherd, op. cit., pp. 10-11.

${ }^{39}$ Munro and Ozanne, op. cit., p. 90.

${ }^{40}$ Turkington, Community Civics, p. 94. See also Forman, First Lessons in Civics, p. 124; Levis, op. cit., pp. 363, 422; Jenks and Smith, op. cit., pp. 125, 103; Rexford and Carson, op. cit., p. 41; Brooks, op. cit., p. 19; Forman, The American Democracy, pp. 21-22; Hughes, Nere Community Civics, p. 202 ; Williamson, op. cit., p. 365; Lapp, op. cit., p. 186; Hughes, Text-Book in Citizenship, pp. 605-6; Reed, op. cit., pp. 76, 95; Guitteau, op. cit., pp. 54-55; Jenks and Smith, op. cit., p. 117.

"Shepard, op. cit., p. 14.

${ }^{42}$ Woodburn and Moran, op. cit., pp. 15-16, 25; Guitteau, op. cit., p. 27.

${ }^{43}$ Hughes, Economic Civics, pp. 52-53; Cabot, op. cit., pp. 164-65.

"Shepard, op. cit., p. 112. Guitteau, op. cit., pp. 20-21.

${ }^{45}$ Guitteau, op. cit., pp. 112-13, 186-87; Mavity, op. cit., pp. 317, 356. 
As the main officers are selected, however, through the vote of the citizen, it is held desirable that political party affiliation be carefully considered. When people vote for candidates on their merits, it is believed party leaders are forced to choose the best men for office and thereby better government is assured. ${ }^{46}$ By some writers, party loyalty is adjudged a good thing, ${ }^{47}$ others holding that "loyalty to the interests of one's country is an infinitely better thing." 48 On the whole, however, it may be said that authors are agreed as to the "necessity" of political parties. "The plain citizen in order to have much weight in the conduct of government ... must combine with others whose views he shares more or less completely," says Beard. "That is, he must join a political party when he has made up his mind about the things which the government ought to do or ought not to do," ${ }^{49}$ for "political parties are institutions for getting the public opinion of the majority written into law."50 Through them majority opinion is expressed. ${ }^{51}$ Yet the need of restraint in the exercise of majority power is touched upon as well, for it is pointed out that the minority possess rights which should be respected. ${ }^{52}$ Forman asserts that either group is not fixed, for, "the minority may become the majority" in good time. ${ }^{53}$ It is

${ }^{46}$ Finch, op. cit., pp. 292-93.

${ }^{47}$ Reed, op. cit., p. 83; Dole, op. cit., p. 167.

${ }^{48}$ Forman, The American Democracy, p. 74. See also Hughes, New Community Civics, p. 189; Forman, First Lessons in Civics, p. 182; Greenan and Meredith, op. cit., p. 28; Williamson, op. cit., p. 361; Woodburn and Moran, op. cit., pp. 53, 20-22; Hill, op. cit., pp. 506, 525; Hughes, Text-Book in Citizenship, pp. 549-65.

${ }^{49}$ Beard, op. cit., pp. 149-50. See also Hughes, Text-Book in Citizenship, pp. 546-47; Hill, op. cit., p. 506; Dunn, op. cit., p. 441; Davis and McClure, op. cit., p. 91; Ashley, op. cit., p. 115; Shepherd, op. cit., pp. 8, 33; Hayes, op. cit., p. 137; Gettell, op. cit., p. 129; Greenan and Meredith, op. cit., pp. 32-33; Munro and Ozanne, op. cit., pp. 145, 155; Finch, op. cit., p. 293; Hughes, Economic Civics, pp. 72-73.

${ }^{\text {so }}$ Burch and Patterson, op. cit., pp. 88-89.

${ }^{\circ 1}$ Ziegler and Jacquette, op. cit., p. 142.

${ }^{52}$ Berry and Howe, op. cit., p. 5; Munro, op. cit., pp. 54-55; Dole, op. cit., p. 190.

${ }^{63}$ Forman, The American Democracy, p. 5. See also Ames and Eldred, op. cit., pp. 338-39. 
held, however, that "a true American always respects law and order and is willing to abide by the will of the majority as it expresses itself through our form of government."

Yet "the Constitution of the United States and the state constitutions have so limited the powers of our law-making bodies that abuse of power by the majority has been rendered difficult," declare Ames and Eldred. ${ }^{55}$ The significant point in the textbooks is that majority rule is supposed to represent the people's will. In other words, it is the rule of the people in which there is afforded protection to the minority through a separation of powers. ${ }^{56}$

To this will expressed through legislative acts, it is the duty of people to acquiesce, textbooks say. "The first duty of a citizen is to obey the laws of his country. Without obedience to the law there can be no such thing as good government," declares Forman. The same sentiment is expressed by many other authors. ${ }^{57}$

Besides the exercise of the suffrage, officeholding, and obedience to law, the pupils are urged to consider the necessity of serving on the jury, the payment of taxes, and service to the country in time of war.

"'The citizen's duty as a juryman while not so frequent or constant is sometimes more important than his duty as a voter,"

${ }^{54}$ Finch, op. cit., p. 296. See also Jenks and Smith, op. cit., p. 101.

${ }^{65}$ Ames and Eldred, op. cit., p. 339.

${ }^{56}$ Beard, op. cit., pp. 85-86. Majority rule is discussed also in Hayes, op. cit., p. 11 ; Dunn, op. cit., p. 440; Morgan, op. cit., p. 32 ; Dole, op. cit., pp. 184, 72, 69; Bryant, op. cit., p. 20; Jenks and Smith, op. cit., p. 89.

${ }^{67}$ Forman, First Lessons in Civics, p. 56; also pp. 26-28, 15-16; Guitteau, op. cit., pp. 42-43; Dawson, Organized Self-Government, p. 12; Hughes, Economic Civics, pp. 47, 51; Jenks and Smith, op. cit., p. 42; Ames and Eldred, op. cit., p. 19-20; Bailey, What To Do for Uncle Sam, p. 180; Bryant, op. cit., p. 14; Binford and Graff, op. cit., p. 138; Cabot, op. cit., pp. 160-61; Brooks, op. cit., pp. 158-59; Dunn, op. cit., pp. 57-58; Morgan, op. cit., p. 30; Forman, The American Democracy, pp. 237-38; Rexford and Carson, op. cit., p. 92; Ashley, op. cit., pp. 15-17; Ames and Eldred, op. cit., pp. 13, 8-9; Ziegler and Jacquette, op. cit., p. 10; Greenan and Meredith, op. cit., pp. 251-52; Levis, op. cit., p. 408; Munro, op. cit., p. 52; Munro and Ozanne, op. cit., p. 71; Jenks and Smith, op. cit., p. 89; Garner, op. cit., p. 390 . 
assert Woodburn and Moran. ${ }^{58}$ According to Levis, "The jury system is one of the foundations of our liberty, and its value largely depends on the honest, intelligent and willing service of all good citizens." 59

For the protection afforded by the government, citizens should perform the duty of paying taxes, the reader of textbooks is told. Although it is conceded that "it is not easy to lay taxes justly," or will be, performed for the community." ${ }^{\prime \prime}$ The payment of taxes is, therefore, adjudged "a patriotic duty.",2

"A most serious duty of the citizen to his government is to defend it against its enemies," declares Forman. Then he goes on to point out to his juvenile readers that sometime they may be called upon "to take up arms and fight" for their country. "If such a time should come, you should not flinch," he says, "but should go forth bravely to the battle field, prepared to lay down your life, if necessary." me from injury $I$ ought to be ready to take up arms in its defense" should be the attitude of all, it is declared. ${ }^{64}$

So far as the duties of citizenship are concerned, a quotation

${ }^{58}$ Woodburn and Moran, op. cit., pp. 22-23. See also Greenan and Meredith, op. cit., p. 94; Guitteau, op. cit., p. 20; Ziegler and Jacquette, op. cit., p. 177; Mavity, op. cit., p. 135.

${ }^{59}$ Levis, op. cit., p. 422.

${ }^{60}$ Forman, First Lessons in Civics, p. 61.

${ }^{61}$ Levis, op. cit., p. 363.

${ }^{62}$ Davis and McClure, op. cit., p. 184. See also Reed, op. cit., p. 225; Finch, op. cit., p. 90; Hughes, Economic Civics, pp. 38, 56-58; Burch and Patterson, op. cit., p. 86; Forman, First Lessons in Civics, p. 64; Guitteau, op. cit., pp. 18-19, 136-38; Turkington, My Country, pp. 188, 226, 231; Ames and Eldred, op. cit., p. 341; Hughes, Community Civics, p. 144; Morehouse and Graham, op. cit., p. 328; Ziegler and Jacquette, op. cit., pp. 198-99; Dunn, op. cit., p. 421; Southworth, op. cit., p. 25.

${ }^{63}$ Forman, First Lessons in Civics, pp. 57-58.

${ }^{64}$ Forman, The American Democracy, pp. 89, 83. See also Lansing and Jones, op. cit., p. 96; Reed, op. cit., p. 72; Guitteau, op. cit., p. 19; Ziegler and Jacquette, op. cit., p. 177; Burch and Patterson, op. cit., pp. 85-86; Woodburn and Moran, op. cit., pp. 23-24; Munro and Ozanne, op. cit., pp. 83-84. 
from Gettell's The Constitution of the United States will set forth those commonly accepted:

The duties of a citizen have been stated by a recent author as follows: "To know his country's history and to be proud of it; to understand his own government and to know it; to know the laws and obey them; to be respectful of all duly constituted authority; to be loyal in action, word and thought, to look upon the privilege of suffrage as a sacred thing and to use it as becometh a sovereign prerogative; to bear his portions of the common burdens cheerfully; to serve public office at personal sacrifice and to regard it as a public trust; to fight and die if need be in the nation's cause-these are the first obligations which a free government imposes on its citizens. Citizens are liable to military services and to pay taxes." 65

${ }^{\text {as }}$ Gettell, op. cit., pp. 83-84. 


\section{CHAPTER XV}

\section{THE AMERICAN AND OTHER PEOPLES}

\section{THE PROBLEM OF IMMIGRATION}

The relations of the United States with the peoples of other countries are discussed, in general, under the topics of immigration, American foreign policy, wars, and diplomatic engagements. Far less space is devoted to these subjects in books dealing with government, social and economic problems than in history textbooks.

As in the histories, immigration before the Civil War is generally described as bringing to this country a more desirable class of people than that following 1880. The contributions of various peoples to the development of the United States receive attention, as do the characteristics of the peoples who have not served in so beneficial a manner.

It has always been the policy of this country to welcome to our shores the honest men and women of other lands who wish to come here [says Guitteau], and our country's wonderful development would have been impossible without the brain and muscle of the millions of immigrants who have turned to America as the land of opportunity. ${ }^{1}$ Indeed, through the contributions of immigrants, American art, music, invention, and the learned professions are said to have been enriched to a considerable degree. " "The mingling of many races into one people has given the nation vigor and versatility" as well as "that alert and progressive spirit" which is believed one of "our most valued characteristics." Besides giving "strength to democratic ideals," immigrants have contributed in no small way to American economic advancement in that they have frequently furnished a large supply of cheap labor. ${ }^{4}$

${ }^{1}$ Guitteau, Preparing for Citizenship, p. 205.

${ }^{2}$ Gettell, The Constitution of the United States, pp. 120-26.

${ }^{3}$ Munro and Ozanne, Social Civics, pp. 326-27.

${ }^{4}$ Gettell, op. cit., pp. 120-26. See also Burch and Patterson, Problems of American Democracy, pp. 157-58, 169; Woodburn and Moran, The Citizen 
Yet in spite of the benefits derived from their coming to America, immigrants are charged with keeping down wages and with causing unemployment, with producing slum districts and sweatshops, and with widening the gulf between capital and labor. Nay, more, through their "radical and revolutionary ideas" our political system is believed to be menaced and machine politics to be encouraged. Likewise, foreigners are said to furnish a high percentage of the criminal population, illiterates, and dependents on society, while a tendency to segregation and isolation is advanced against them. ${ }^{5}$

But all faults in American life do not lie with the foreigner, some textbooks assert, for Americans are not always courteous and "sometimes assume a very superior air toward recent arrivals." Certainly during the World War, according to Dunn, the loyalty of the immigrant was unquestioned. ${ }^{7}$

In discussions attending official policies, restrictive measures and regulation of immigration are explained by some authors as due to the fact that "the government wants people who come here to become good citizens," and that those excluded would probably not become such. ${ }^{8}$ While the writer of one book indorsed a qualitative selection of those desiring to enter the United States on the basis of intelligence, education, and physical well-being regardless of the section of the world from which they come, ${ }^{9}$ another holds restriction necessary, not only to exclude diseased and criminal classes, but to keep out paupers, anarchists,

and the Republic, pp. 72-73; Hughes, Text-Book in Citizenship, p. 104; Munro, Current Problems in Citizenship, pp. 25-26; Greenan and Meredith, Everyday Problems of American Democracy, pp. 14-16; Reed, Loyal Citizenship, p. 189; Forman, The American Democracy, p. 324.

${ }^{5}$ See references in preceding footnote. Also Burch and Patterson, op. cit., pp. 171-72; Ashley, The New Civics, pp. 48-49; Hill, Community Life and Civic Problems, pp. 150-52, 162-66; Hughes, Economic Civics, p. 173; Berry and Howe, Actual Democracy, pp. 167-68.

${ }^{6}$ Greenan and Meredith, op. cit., p. 18; Hughes, Text-Book in Citizenship, p. 103.

${ }^{7}$ Dunn, Community Civics for City Schools, pp. 80-81.

${ }^{8}$ Ames and Eldred, Community Civics, pp. 142-43.

${ }^{9}$ Munro, op. cit., p. 28. 
convicts, and other undesirable persons from European countries using the United States as "a dumping ground."10

In order to unify all diverse elements in the structure of American citizenship, several textbook authors advocate that all people be made to speak the English language since, according to one writer, "something very dangerous to freedom can happen if all Americans do not speak and use English." As a case in point, this author declares that in 1918 the very great number of Germans in this country who did not speak English led the German government to prepare "to conquer America." For did not the German government know "that people could more easily be made untrue to America if they knew no English"? With this in mind, the pupil is told how the German government had sent "clever men here, to start German newspapers, to publish German books and to get votes so that German should be taught in the primary schools in towns where many Germans lived," and how "some of these people became a real secret army for the Kaiser, against the country they called their own."11 With such a picture of possible but averted disaster in 1918, the pupil is urged now to protect and cherish the English language as the only safe method of communication. ${ }^{12}$

\section{THE ENGLISH}

"English immigrants have been of two widely-differing classes," according to Berry and Howe. "One, well-educated, professional and commercial men and skilled artisans, brings considerable money and contributes a worthy element to our population; the other is a lower type and has been a burden rather than otherwise." Jenks and Smith ascribe to the English the quality of tenacity of purpose, exemplified in Nelson at Trafalgar. ${ }^{13}$

${ }^{10}$ Guitteau, op. cit., p. 205.

${ }^{11}$ Bryant, $I A m$ an American, pp. 83-88. See also Turkington, $M y$ Country, pp. 46, 52.

${ }^{12}$ Ibid.

${ }^{13}$ Berry and Howe, op. cit., p. 160; Jenks and Smith, We and Our Government, p. 22. 
The chief references to our relations with England, however, deal with the Colonial and Revolutionary periods. On the whole, the treatment is far less hostile than in histories, and, in general, relates to the political legacy bequeathed English colonists. It is pointed out that American ideals are English in origin, that American leaders such as Washington, John Hancock, and Samuel Adams were of English blood, and that "the character of the English is still in the character of the Americans."14 Furthermore, considerable stress is laid upon the fact that our governmental forms are inherited from Great Britain, that the Magna Charta, Petition of Right, and Bill of Rights laid the foundation of American political documents. ${ }^{15}$ The principal rights and privileges assured Americans are called English in origin, and as the child of England have been absorbed and adopted by America. ${ }^{16}$

So far as the Revolutionary War and the War of 1812 are concerned, the discussions would not tend to cultivate strong enmities in pupils by a reading of the textbooks. As in the histories, however, some writers place the blame of the uprising of 1776 upon King George III, ${ }^{17}$ and it is made the result of a "violation of rights and liberties of Englishmen, inherited by and guaranteed to the colonists."18 According to Hayes, "It was the unquenchable determination on the part of the colonies to manage their own affairs.' America was bound to be free."19

Munro makes the cause of the Revolution economic rather than political, and declares that the colonists revolted, not because they wanted "to elect their own governors or to secure

${ }^{14}$ Bryant, op. cit., pp. 45-46.

${ }^{15}$ See p. 23. Hayes, American Democracy, pp. 13, 77-78; Morgan, Living and Working Together, pp. 171-74, 188, 193; Lansing and Jones, Government in State and Nation, pp. 19-20; Berry and Howe, op. cit., chap. II; Hughes, Economic Civics, p. 43; Southworth, The Common Sense of the Constitution, p. X; Rexford and Carson, The Constitution of Our Country, pp. 4-6.

${ }^{16}$ Berry and Howe, op. cit., pp. 14-16, 20-21; Davis and McClure, Our Government, pp. 139-41; Gettell, op. cit., pp. 71-73.

${ }^{17}$ Finch, Everyday Civics, p. 162; Hepner, The Good Citizen, p. 71; Morgan, Living and Working Together, pp. 174-75.

${ }^{18}$ Lansing and Jones, op. cit., p. 25.

${ }^{19}$ Hayes, op. cit., p. 65. 
manhood suffrage," but because they "detested the restrictions that were being placed on their trade and industry." 20 Mavity, on the other hand, says, "The American Revolution was made necessary by the fact that the Americans were without representation in the British Parliament."21

Berry and Howe, however, summarize the Revolution thus:

The conflict then begun was not as we see it now; the desperate unanimous rising of an oppressed continent driven to rebel by unbridled and unbearable tyranny, as patriotic historians following the lead of Revolutionary orators long pictured it. .... It was the translation into arms of thoughts and interests long tending consciously and unconsciously to rupture. ...."

They still further point out that it was a struggle for English rights, quoting an Englishman as saying: "Englishmen now understand that in the American Revolution you were fighting our battles."22

The few authors who include in their books discussions relating to the War of 1812 show that both France and England were violating American neutrality, but that England "stirred up the greatest amount of popular resentment," war was waged at heavy cost but with no conclusive results. ${ }^{24}$

Several textbooks attempt a comparison of the government of Great Britain with that of the United States, particularly as to the degree of democracy possible under the two forms. According to Hayes,

The assertion is often made that the government of England is more sensitive to the will of the people than is the government of the United States, but when we realize the contrast between the social life in America and that in England, where class is strongly marked; when we remember that a hereditary House of Lords is one branch of the British government; when we consider that in the conduct of

${ }^{20}$ Munro, op. cit., p. 38.

${ }^{21}$ Mavity, Responsible Citizenship, p. 243.

${ }^{22}$ Berry and Howe, op. cit., pp. 26, 28. These authors quote Abbott.

${ }^{23}$ Munro and Ozanne, op. cit., p. 598. See also Burch and Patterson, op. cit., p. 104.

${ }^{24}$ Gettell, op. cit., p. 149. 
foreign affairs the English people have nothing to say, we may fairly conclude that the assertion is not true. ${ }^{25}$

Another writer points out that "England today has a king that she loves, but he has no power to harm the people," and that the divisions of official functions are similar to ours, ${ }^{26}$ while still another writer concludes that "in many respects the government of Great Britain today is as democratic as ours.",27

In emphasizing the common ties and interests of the Englishspeaking peoples, in some cases authors go so far as to urge an alliance or at least an entente cordiale between England and America as a step which would be mutually advantageous. They declare:

Great Britain is an American power, with more territory in the Western World than has the United States itself. Great Britain helped to originate the Monroe Doctrine in 1823; she has since generously recognized it in restraint of her own aggrandizement, while her navy, together with that of America, has been the main defense against European encroachments.

Britain and America are territorial neighbors with an unfortified frontier boundary line of 3,000 miles between them, the English speaking peoples of America and Canada have lived side by side in an unbroken peace for more than one hundred years. In the Great War they fought together to save themselves and the world against an autocratic, war-making military power which would override the Monroe Doctrine to extend its dominions in America as soon as its interests prompted and its powers permitted. ${ }^{28}$

THE FRENCH

"French immigration," say Berry and Howe, "has never been very large, but has been very desirable, as the French are characterized by intelligence, education, and thrift." 29

Not only do we think of education, intelligence, and thrift as qualities of the French, but there is also brought to our minds,

${ }^{25}$ Hayes, op. cit., p. 49.

${ }^{28}$ Turkington, op. cit., pp. 297-98.

${ }^{27}$ Mavity, op. cit., p. 9. See also Hughes, Economic Civics, p. 43.

${ }^{28}$ Woodburn and Moran, op. cit., pp. 370-71.

${ }^{29}$ Berry and Howe, op. cit., p. 160. 
according to another textbook, the spirit which expressed itself "in those immortal words at the Battle of Verdun: 'They shall not pass!" "30

Indeed, within the pattern of Franco-American relations are woven only the designs of gratitude and friendship. "It is doubtful whether we could have won our independence from Great Britain had it not been for the help of our ally France" is the opinion of Greenan and Meredith. ${ }^{31}$

When we think of the service Lafayette did us, we must also think of the Americans who went to serve his country in her hour of need [says Bryant]. When the freedom of France was attacked by Germany in 1914, many young American men did not wait for America to join the war. They went to war at their own expense, and said to the French government, as Lafayette had said, "We will serve as volunteers without pay." 32

\section{THE GERMANS}

There is little in the textbooks of social, political, and economic problems to cultivate an admiration and liking for Germany. In some cases, where German immigration to this country is discussed, the Germans are described as "thrifty and industrious," easily assimilable, although tending to settle in communities of their own, and as having made a real contribution to the American commonwealth. ${ }^{33}$ As in histories, the chief emphasis in Germanic-American relations, however, is centered upon the World War, in which authors treating the subject carol a lay of hate. It is the opinion of Woodburn and Moran that:

The Great War revealed the nation in Europe against whose hostility and spirit of conquest America needs to be on her guard. The imperial and military rulers of Prussia, with their purpose of obtaining "a place in the sun," have looked, not only to Asia and Africa, but to South America for commercial and colonial enlarge-

${ }^{30}$ Jenks and Smith, op. cit., p. 22.

${ }^{31}$ Greenan and Meredith, op. cit., p. 189.

${ }^{32}$ Bryant, op. cit., pp. 41-42.

${ }^{33}$ Berry and Howe, op. cit., pp. 160-61; Burch and Patterson, op. cit., pp. 159-60; Munro, op. cit., p. 24; Burch, American Economic Life, p. 135. 
ment. The Monroe Doctrine has been an obstacle in their path. German hostility to that doctrine is well known. ${ }^{34}$

As proof of Germany's greediness, as well as evidence of perfidy and cruelty, the story of the invasion of Belgium is chronicled for the young readers. In this "she was doing what no nation, however great and powerful, has a right to do even in time of war," declares Turkington. "Even George the Third had more excuse for sending an army to America in 1776 than Germany had for invading Belgium and France.",35

The use of the submarine by Germany is pictured vividly by Bryant in I Am an American. Excerpts from this book, designed for elementary-school use, will illustrate the extent to which some authors indulge in the use of colorful adjectives and other invectives :

In February, 1915, the German government said to the world, "We are going to send our submarines out into the ocean around England, and sink every ship that comes near, no matter what country it belongs to, nor what it carries. We do not care whether it is a passenger ship or where it is going. . . . We will not give any warning, or try to save the people. We shall torpedo every ship we can catch. We will starve England at any cost to the world." The German government said this in more grown-up words, but this is what the words meant. ....

This was a violation of International Law and of The Hague promises. It was more than that, it was a violation of the human conscience. The world could not believe that Germany meant it.

On a spring day in 1915 the great steamship Lusitania sailed out of New York Harbor to cross to England. . . . . There were many families on board. Many mothers and little children who had to go home to England, Scotland, or France were traveling on the Lusitania because she was so safe and swift. There were more than a thousand people on board who had nothing at all to do with the war.

On the 7th of May, when the Lusitania was almost at the coast of England, an unseen submarine shot two torpedoes into her. There were two fearful explosions, and instantly the Lusitania began to sink. In the terrible fright and confusion, the crew hurried as fast as they could to lower the life boats. Brave men rushed about putting

${ }^{34}$ Woodburn and Moran, op. cit., pp. 369-70.

ss Turkington, op. cit., pp. 28, 303-4. 
little children in the boats, and helping women. But faster and faster the Lusitania settled under them. There was no time, no help, no hope.

In less than twenty minutes the great ship sank to the bottom of the sea, and all those hundreds of mothers and fathers and little children were struggling in the icy water.

Poor little babies! Like wax dolls, they floated a moment on the waves, helpless, then they sank beneath the whirling waters and were drowned.

One thousand, one hundred and ninety-eight people were murdered at sea that day by the German government and its submarine!

While the whole civilized world was filled with horror and pity, Germany held a special holiday for her school children, to celebrate the sinking. The German newspapers said, "With joy and pride we contemplate this latest deed of our navy." And Germany had medals made, celebrating the sinking of the Lusitania and making fun of the people who had sailed in her $!^{36}$

Thus, it became inevitable that the United States be involved in the struggle, the pupils are told. Not only the infringement of American rights is given as a reason for our entrance, but the need of self-defense. For, according to Woodburn and Moran,

America does not wish to be Germanized nor to have cultivated among her people the Prussian idea of world conquest and war. To prevent this, and to bring it about that the world may be ruled by reason and self-control instead of brute force, that the world may be made a safe place in which individuals and democratic nations may develop their own lives without fear of becoming the prey of foreign aggression, America was forced to depart from her isolation and enter the great World War. ${ }^{37}$

\section{PEOPLES OF THE FAR EAST}

The arguments advanced against oriental immigration in the histories are largely reproduced in the books considered in this section. According to Towne,

All the arguments against immigration apply with increased force

${ }^{38}$ Bryant, op. cit., pp. 113-14. The excerpt quoted is typical of the contents of this book.

${ }^{37}$ Woodburn and Moran, op. cit., pp. 370-71. See also Hayes, op. cit., pp. 212-33. Cabot's $A$ Course in Citizenship indicates that the Kaiser's rule for twenty-five years demonstrated his interest in his people (p. 230). 
against oriental immigration. The orientals not only have lower standards of living, but they also so materially differ from the American people in language, religion, and customs, as to constitute an entirely new problem. While many of the European races present problems of assimilation, the oriental has such different racial characteristics, as to be quite impossible of assimilation. The fear is that should we permit the Asiatics to come here as freely as we permit other races, we would soon have on our hands a Japanese problem and a Chinese problem, quite as serious as our present-day negro problem. $^{38}$

Other authors believe restrictive measures against orientals especially necessary owing to the great numbers who would come to our shores, numbers among whom there is a high rate of illiteracy, who do not desire to make America a permanent home, who lack assimilability, and who have a lower standard of living and therefore demand a lower wage for their services than American laborers. ${ }^{39}$

Hill, in his Community Life and Civic Problems, attempts to show the source of antagonism felt by Americans toward oriental groups by pointing out the result of hard times after the completion of the Union Pacific Railroad. "Anger against the hardworking, little-eating, frugal, stolid, yellow-skinned Chinaman quickly appeared, and riots, mobs, and lynchings became frequent," he says. ${ }^{40}$

The glory of the ancient civilization of China, on the other hand, the Chinese as trustworthy, honest, just, and energetic are occasionally mentioned..$^{41}$ Nor does the historic friendship of the United States through the policy of the Open Door fail of attention. ${ }^{42}$

In contrasting the characteristics of Chinese and Japanese, Towne, for example, ascribes to the former a greater trustworthiness in discharging their contracts and in doing their work with

${ }^{3 s}$ Towne, Social Problems, p. 53.

${ }^{30}$ Burch and Patterson, op. cit., pp. 173-74. See also Greenan and Meredith, op. cit., p. 17; Munro, op. cit., pp. 30-32; Mavity, op. cit., p. 126; Ellwood, Sociology and Modern Social Problems, pp. 241-44.

\footnotetext{
${ }^{40}$ Hill, op. cit., p. 154. ${ }^{41}$ Jenks and Smith, op. cit., p. 22.

${ }^{42}$ Munro and Ozanne, op. cit., p. 618.
} 
care, while to the latter is attributed more aggressiveness in becoming landowners and proprietors, especially in the western section of America. ${ }^{43}$

The situation which has developed for the federal government out of objections raised by California is shown to have arisen, in the case of the Japanese, because of unassimilability, and Japanese exclusion is presented as "probably the kindest policy for both races." 44 Some authors see "in the rapid growth of their military and naval strength" a rival for the mastery of the Pacific. ${ }^{45}$

In spite of all alleged disagreeable characteristics of the Chinese and Japanese, Hughes maintains that they are a wonderfully progressive people and Americans should not say disagreeable things about them. ${ }^{46}$

Of other peoples of the Far East Hindus are described as even "less desirable than the Chinese and Japanese" for "they are more caste ridden, mingle less with other people than do other races, and are found almost exclusively in the ranks of the lowest grade of unskilled laborers." 47

THE PEOPLES OF SOUTHERN AND EASTERN EUROPE

Discussions attending migration to America from Southern and Eastern Europe tend to stress deleterious rather than beneficial results. For example, Morehouse and Graham declare:

Puritanism in American life has been greatly affected by the influx of new peoples, mostly from South European lands. The old strict Sabbath, for instance, has definitely disappeared in certain parts of the country and has been modified everywhere. In the cities moral conditions are worse than they were before the foreign influx. .... The new immigration has reduced democracy in our land.

${ }^{43}$ Towne, op. cit., pp. 54-55.

${ }^{44}$ Mavity, op. cit., p. 128. See also Munro, op. cit., pp. 31-32; Ellwood, op. cit., pp. 241-44.

45 Munro and Ozanne, op. cit., p. 618.

${ }^{45}$ Hughes, Text-Book in Citizenship, p. 107.

${ }^{47}$ Towne, op. cit., p. 55. See also Fairchild, Elements of Social Science, p. 368. 
.... The new races have brought over race antagonisms with them that introduce new discord into our national life. ${ }^{48}$

In the case of the Italians, it is alleged that they migrate to this country "chiefly for economic reasons," for they "look with longing eyes to America, the land of opportunity and riches." 49 Berry and Howe distinguish between the northern and southern Italians as to desirability as settlers, holding the former possess "many of the admirable characteristics of the Northern Europeans," while the latter are "less educated and have the fiery passions of the oriental."50 The southern Italians are said to have "an unenviable police record," 51 but they are also characterized as often "frugal and industrious workers" and frequently "handicapped by their ignorance of the English language." Jenks and Smith mention, not only their industry, but "their love for art and music."53

In like manner, the Czechoslovaks are said to "constitute a valuable element in our population." Some writers consider the Slavs difficult to assimilate into American life, ${ }^{54}$ and as belonging "almost entirely to the class of unskilled labor which finds occupation in the mines and in the great manufacturing industries where brawn, not brain, is essential."955

Greeks, Syrians, and Armenians are likewise described as unassimilable, for upon their arrival in America "they go at once to the quarters of their fellow countrymen where congestion, disease, and poverty abound."56 Added to these groups is the immigrant Jew thought to be inclined to segregation, but described

${ }^{48}$ Morehouse and Graham, American Problems, pp. 366-67. See also Hepner, op. cit., pp. 313-14; Woodburn and Moran, op. cit., p. 72.

49 Burch, op. cit., pp. 135-36.

${ }^{\text {so }}$ Berry and Howe, op. cit., p. 162.

${ }^{51}$ Burch and Patterson, op. cit., p. 171.

${ }^{52}$ Burch, op. cit., pp. 135-36.

${ }^{s 3}$ Jenks and Smith, op. cit., p. 22.

s4 Burch and Patterson, op. cit., p. 164.

${ }^{s 5}$ Ibid., p. 110. See also Burch, op. cit., p. 136.

${ }^{56}$ Berry and Howe, op. cit., p. 163. 
as of superior mental ability, industrious, personally ambitious, generous, and noted for fine family life. ${ }^{57}$

THE NEGRO, THE INDIAN, AND THE MEXICAN

In the consideration of the negro problem in America by some writers, it is pointed out that negroes are "a race so far removed from the white population of the United States that there is danger of misunderstanding the other." ${ }^{958}$ The problem of the negro is "one of the many race problems which the United States has," declares Ellwood, "but because it is the most pressing of all our race problems it is frequently spoken of as the race problem." 959 Although described as being addicted to crime to an unwarranted degree, ${ }^{60}$ the colored race is said to have made commendable progress in general since the Civil War. ${ }^{61}$

Little is said about the Indian in the books surveyed in this section of the study, but Burch and Patterson indicate that American dealings with the Indian in the past were not always free from corruption and injustice. ${ }^{62}$

A paucity of treatment is found regarding Mexico, the few authors mentioning the country agreeing, on the whole, that the government is poor, the people poverty-stricken and ignorant. ${ }^{63}$ Mavity, in speaking of the Mexican War, remarks that it is "generally regarded as having less justification than any other war in which the United States has been engaged," 64 and Munro and Ozanne point out that, since 1846, the Mexicans have looked with suspicion upon the United States."

${ }^{5 \tau}$ Ibid., p. 161. See also Burch, op. cit., p. 136; Burch and Patterson, op. cit., p. 164 .

${ }^{58}$ Munro and Ozanne, op. cit., p. 30.

${ }^{59}$ Ellwood, op. cit., p. 246. Italics are in the original.

${ }^{80}$ Burch and Patterson, op. cit., pp. 187-90.

${ }^{61}$ Hughes, Text-Book in Citizenship, p. 109.

${ }^{62}$ Burch and Patterson, op. cit., p. 192.

${ }^{63}$ Long, Government and the People, p. 3; Brooks, Our Dual Government, pp. 90-91; Turkington, op. cit., p. 236.

${ }^{64}$ Mavity, op. cit., p. 165.

es Munro and Ozanne, op. cit., pp. 615-17. 


\section{THE FOREIGN POLICY OF THE UNITED STATES}

Discussions dealing with the foreign policy of the United States hinge upon the pronouncements of the chief executives before Monroe and the Monroe Doctrine, its past and present applications, the economic expansion of the United States, and such gatherings to promote international concord as the Pan-American congresses. The influence of the Spanish-American War in making the United States a world-power does not fail of attention. ${ }^{68}$ Today, declare Munro and Ozanne

there is no part of the world, in fact, to which the interest of the United States, direct or indirect, sentimental, political, or economic, does not now extend. The enormous strength and prestige of America, as disclosed during the war, have made a profound impression in every part of the globe and given the United States a potent influence over the destinies of mankind. The United States has become a world power of the first order. Whether the American people like it or not, that inexorable fact remains. ${ }^{67}$

Woodburn and Moran, likewise, call attention to the changes wrought by time, declaring political isolation wise when first applied, but that America has now emerged to the status of a worldpower.

It took the Pilgrim Fathers sixty days to reach America from Europe [they point out]. It takes five days now, and communication is instantaneous. The Atlantic Ocean is no longer a barrier but a highway between nations, and for certain purposes a subway. Responsibilities are forced upon us which we cannot avoid. ${ }^{68}$

Munro and Ozanne trace the interest and participation of this country in European affairs, beginning with our invasion of the Mediterranean in 1803 against the Barbary pirates. Then followed the War of 1812, growing out of foreign interference with American trade. Owing possibly to geographical position, these authors hold it was possible to keep out of difficulties of an inter-

${ }^{\circ 0}$ Greenan and Meredith, op. cit., pp. 190-91; Burch and Patterson, op. cit., pp. $105-6$.

er Munro and Ozanne, op. cit., p. 621.

${ }^{c 8}$ Woodburn and Moran, op. cit., p. 383. See also Dunn, op. cit., p. 95; Munro and Ozanne, op. cit., p. 587, for changes in transportation and the results. 
national character for the greater part of our history. Furthermore, there was room for expansion on this continent. Then came the World War by which America was brought into contact with the whole world. Following the Spanish War, the United States had acquired colonies, moreover, so that "American interests now extend to everything that may threaten peace." ${ }^{\mathbf{9 9}}$

On the other hand, the isolationist's point of view is expressed by Lapp, when he says:

The aim of the country has always been to keep out of any union with foreign countries. The interests of the great nations of Europe are their own and we have nothing to do with them except to protect the interests of our citizens. Washington, in his farewell address, cautioned our people to avoid all connections which would lead us into trouble with foreign nations. His advice ought to be read today and heeded by all. ${ }^{70}$

In regard to European interference with American affairs, direction is held to be entirely within the province of the United States, keeping Europe out "peaceably if we can, forcibly if we must." 71

For this purpose "the permanent purpose of the Monroe Doctrine is to keep the peace on this side of the Atlantic against aggression and attack by European powers, in order that every nation in the two Americas may be left free to control its own territory and work out its own destiny and progress in its own way." The Doctrine has been "variously interpreted at different times," but "we have striven to be consistent by not participating in European affairs," declare Burch and Patterson. ${ }^{73}$

Out of the Doctrine has sprung the spirit of pan-Americanism,

${ }^{69}$ Munro and Ozanne, op. cit., pp. 606-15. See also Gettell, op. cit., pp. 150-57; Cabot, op. cit., pp. 282-325.

${ }^{70}$ Lapp, America, pp. 297-98.

${ }^{71}$ Woodburn and Moran, op. cit., p. 368.

${ }^{72}$ Ibid., p. 369. References to American foreign policy in Brooks, op. cit., pp. 161-62; Dunn, op. cit., pp. 93-94; Ashley, op. cit., pp. 367-70; Dawson, Organized Self-Government, p. 269; Greenan and Meredith, op. cit., pp. 189-90; Munro and Ozanne, op. cit., pp. 597-601; Mavity, op. cit., p. 167; Hayes, op. cit., pp. 278-99.

${ }^{73}$ Burch and Patterson, op. cit., pp. 104-5. 
which is no small force in directing the destinies of both South and North America. ${ }^{74}$ The Doctrine, furthermore, is described as having compelled us to assume a large measure of responsibility for the proper government of such countries as Santo Domingo and Haiti, "which are practically protectorates of the United States." "75 Protectorates over Cuba and Nicaragua also are mentioned as due to a desire "to prevent confusion in business affairs" and for the sake of stabilizing government. ${ }^{76}$

In its relations with its possessions, the United States is said to have conferred upon its dependencies as much self-government as the peoples were qualified to exercise, and to have increased their share in government as rapidly as possible. In short, "its policy has given attention to the needs and interests of the dependencies, as well as to its own interests at home."

On the whole, it may be said that authors treating the subject of our foreign policy agree that "splendid isolation" as originally practiced is no longer possible. Commerce between nations is made responsible for developing a permanent interest in Americans in peoples of other continents as well as promoting "international good feeling and friendship." Indeed, say Munro and Ozanne, "Isolation makes for suspicion and war. World commerce makes for peace."

${ }^{74}$ Ashley, op. cit., pp. 369-70; Munro and Ozanne, op. cit., p. 617.

${ }^{75}$ Greenan and Meredith, op. cit., pp. 172, 190.

${ }^{76}$ Gettell, op. cit., pp. 115-16.

${ }^{7}$ Ibid., p. 116. See also Forman, op. cit., pp. 151-52; Reed, op. cit., pp. 223, 236; Guitteau, op. cit., p. 203; Burch and Patterson, op. cit., pp. 105-6; Munro, op. cit., pp. 495-501.

${ }^{78}$ Munro and Ozanne, op. cit., pp. 377-78. See also Hughes, Economic Civics, p. 192; Burch and Patterson, op. cit., pp. 106-7. 


\section{CHAPTER XVI}

\section{THE ACHIEVEMENTS OF AMERICA}

Many of the same impressions regarding the achievements and glories of the United States as gleaned from history textbooks will be gained likewise from a reading of the textbooks in government and in social and economic problems. For they hold, also, that in America there is equality of opportunity, equality before the law, and no social distinction. ${ }^{1}$

America is the one country in the whole world where each man has the same chance as every other man [declares Turkington]. Whether he was born in Ohio or in Italy does not matter. If he is brave and patient, not afraid of years of the hardest kind of work, he will win success and happiness. ${ }^{2}$

It is here that there is freedom to choose one's calling, an equal chance to make a living and to obtain compensation for labor. For these things more than anything else, according to Dunn, people have emigrated to America. ${ }^{3}$ Indeed, the economic opportunities open to foreigners have been an impelling force in bringing them to America is the opinion of Hughes. "They had heard wonderful stories of America, the richest land in the world," he says. "The demand for labor here was great and the workman received better wages than he could ever expect to earn in any foreign country. Besides living conditions have always been better here than elsewhere." In other words, the United States is the "richest country in the world," where "every citizen has a chance to get honestly all that he needs to make him

${ }^{1}$ Mavity, Responsible Citizenship, pp. $16 \mathrm{ff}$; Long, Government and the People, p. 1; Turkington, My Country, pp. 41, 228; Morehouse and Graham, American Problems, p. 356 ; Turkington, Community Civics, p. 226; Hughes, Text-Book in Citizenship, pp. 707-8; Dunn, Community Civics for City Schools, p. 297.

${ }^{2}$ Turkington, My Country, pp. 15-16. $\quad{ }^{3}$ Dunn, op. cit., p. 297.

${ }^{4}$ Hughes, Economic Civics, p. 172. See also Hughes, Text-Book in Citizenship, p. 93. 
happy and successful."5 For "when we think of the United States, we think of opportunity, speed, individuality, vision, earnestness of purpose and resourcefulness." 6

Not only have material things attracted to our shores the peoples of other lands less blessed, but freedom from military requirements, the right to worship according to one's conscience, and political freedom. ${ }^{7}$ Into the land of liberty came, then, the oppressed of other countries to obtain for themselves the. blessings of "justice, righteousness and liberty" upon which America is founded. ${ }^{8}$ Here they find a "self-respecting independence" both politically and economically. "The United States is "the first great successful Democracy,"10 a government whose principles have been adopted by other lands desiring to establish democratic institutions, and where there is lacking "the countless fixed ideas and customs that so largely determine the actions of older civilizations," for we are not "unduly hampered by worn-out national traditions."11

For the many advantages and blessings with which America is said to be filled, we are indebted to our forefathers, say the textbooks. Those who preserved for us our rights and liberties by fashioning the Constitution were "the most notable" group

- Bryant, I Am an American, pp. 66-68. See also Turkington, Community Civics, pp. 10-13, 7-9; Munro, Current Problems in Citizenship, p. 484; Woodburn and Moran, The Citizen and the Republic, p. 353; Brooks, Our Dual Government, pp. 17, 159-161; Hall, Immigration, p. 17; Binford and Graff, The Young American Citizen, p. 294; Turkington, My Country, pp. 4-11, 18-19.

- Jenks and Smith, We and Our Government, p. 23. See also Morehouse and Graham, op. cit., pp. 354-55; Long, op. cit., p. 1.

'Hayes, American Democracy, p. 211; Berry and Howe, Actual Democracy, pp. 157-58; Long, op. cit., p. 1.

${ }^{8}$ Hill, Community Life and Civic Problems, p. 158. See also Turkington, My Country, pp. 57-62, 22-23; Rexford and Carson, The Constitution of Our Country, p. 116; Mavity, Responsible Citizenship, pp. 28 ff.; Greenan and Meredith, Everyday Problems of American Democracy, p. 85.

- Morehouse and Graham, op. cit., p. 357.

${ }^{10} \mathrm{Jenks}$ and Smith, op. cit., p. 23. See also Brooks, op. cit., pp. 17, 118-19; Long, op. cit., pp. 407-8; Mavity, op. cit., pp. 213, 12.

${ }^{11}$ Burch and Patterson, Problems of American Democracy, pp. 31-32. 
ever assembled in this country. ${ }^{12}$ And of the men of our early history, "the greatest" was George Washington. ${ }^{13}$ Patrick Henry, George Rogers Clark, John Paul Jones, James Madison, Alexander Hamilton, and Benjamin Franklin are likewise accorded high praise. ${ }^{14}$

Many of these men are responsible, it is said, for the American flag, for which they "had to pay a big price." 15 Of heroes of a later time the books mention, among others, Andrew Jackson, John Quincy Adams, Webster, Clay, Marshall, and Lincoln, ${ }^{16}$ to all of whom is due a debt of gratitude. The valor and achievements of heroic figures in America so impressed a French visitor to an American school that it is said that he exclaimed: " $\mathrm{Ah}$, that we had the great lives to lay bare before our boys and girls that you have here in America! Think of three such great leaders as Washington, Lincoln and Roosevelt belonging to one country!" " 17

The American has cause for just pride also in the fact that "our flag has never known defeat," in wars fought always "to win liberty for somebody."19 Besides defending its citizens and their possessions against foreign enemies just as do other countries for their citizens, the United States is said to have been "successful above most nations" in making such defense effective. ${ }^{20}$ For this common defense, the people "need an army and navy," according to Lapp. ${ }^{21}$ And, although the greater part of the

${ }^{12}$ Guitteau, Preparing for Citizenship, pp. 154-55; Southworth, The Common Sense of the Constitution, p. ix.

${ }^{13}$ Brooks, op. cit., pp. 91-94; Bryant, op. cit., pp. 33-35; Hayes, op. cit., p. 155.

${ }^{14}$ Bryant, op. cit., pp. 36-39. ${ }^{15}$ Ibid., p. 24.

${ }^{13}$ Ibid., pp. 57-58; Hayes, op. cit., p. 155.

${ }^{17}$ Finch, Everyday Civics, p. 295. ${ }^{18}$ Ibid., p. 298.

${ }^{19}$ Turkington, My Country, pp. 37-38. See also Dunn, op. cit., pp. 96-97. Most books make the World War a war for democracy.

${ }^{20}$ Reed, Loyal Citizenship, pp. 64-65.

${ }^{21}$ Lapp, Our America, p. 25. See also Turkington, My Country, pp. 320-24; Mavity, op. cit., pp. 169-70; Hughes, Text-Book in Citizenship, p. 624; Ashley, The Nere Civics, pp. 371, 377-78; Reed, op. cit., pp. 289-90; Forman, The American Democracy, p. 248; Ames and Eldred, Community Civics, pp. 74-75; Bryant, op. cit., 101-5. 
national income may be spent on the upkeep of its military forces, it must be remembered, declare some of the authors, that "the most important duty" of the nation is "that of defending us from the attacks of other nations." ${ }^{22}$

Dole, on the other hand, presents an argument against preparedness as practiced, asserting that where armies are ready for use men will be found ready to use them. ${ }^{23}$ Some authors express an opinion that "war is horrible," but they do not advocate the abandonment of a preparedness program. ${ }^{24}$

On the other hand, the United States is made a lover of worldpeace, a country whose record is unequaled in an "influence to lead the world to peace." 25 It is held by one author that today "what is required is not less loyalty to one's nationality, but more sympathetic understanding of nationalities and national ideals different from one's own, combined with a recognition of the fundamental interests . . . . which unite them to each other." ${ }^{26}$

As the symbol of the unity to which allegiance is owed, the American flag is accorded attention either in passages urging expressions of loyalty or in passages dealing with flag etiquette. ${ }^{27}$ As

${ }^{22}$ Jenks and Smith, op. cit., p. 139. See also Munro and Ozanne, Social Civics, p. 563; Ziegler and Jacquette, Our Community, p. 51.

${ }^{23}$ Dole, The Nere American Citizen, pp. 349, 364. See also Greenan and Meredith, op. cit., p. 164. Greenan and Meredith, in their book, and Munro and Ozanne, in their Social Civics, list classes interested in expansion and having imperialistic schemes in mind. The former mention people alleged to desire war under certain conditions. See Greenan and Meredith, op. cit., pp. 164-65; Munro and Ozanne, op. cit., p. 620.

${ }^{24}$ Turkington, Community Civics, p. 490; Ames and Eldred, op. cit., p. 173; Greenan and Meredith, op. cit., pp. 159-61; Munro and Ozanne, op. cit., p. 583; Morehouse and Graham, op. cit., p. 556; Hughes, Nere Community Civics, pp. 288-89; Hill, Lessons for Junior Citizens, pp. 197-207.

${ }^{25}$ Reed, op. cit., pp. 291-92. See also Greenan and Meredith, op. cit., p. 161; Munro, op. cit., pp. 470-78; Dole, op. cit., p. 349; Hughes, Nere Community Civics, pp. 289-93; Forman, op. cit., pp. 252-64; Dunn, op. cit., pp. 99-103.

${ }^{28}$ Dunn, op. cit., pp. 104-5. See also Morgan, Living and Working Together, pp. 269-70; Finch, op. cit., p. 20; Ashley, op. cit., p. 33.

${ }^{27}$ Davis and McClure, Our Government, pp. 250-57; Ziegler and Jacquette, op. cit., p. 179; Rexford and Carson, op. cit., pp. vi, 143-45; Brooks, op. cit., pp. 168-71, 173-75; Bailey, What to Do for Uncle Sam, pp. 129-36; Turkington, My Country, pp. 360-68; Hughes, Economic Civics, p. 51; Bryant, op. cit., pp. 22-23. 
a token of the love felt for the flag and the country for which it stands, "The American's Creed," by William Tyler Page, and the "Athenian Oath" find a place in some of the textbooks. ${ }^{28}$

In closing her book designed for the upper elementary grades, Sara Cone Bryant, in $I$ Am an American, puts in words for her readers this confession of faith in America:

I am an American. My country is the freest, the richest, and the most beautiful land on earth.

My Flag is unstained. My Navy is unconquered. My Army defends the freedom of the world.

The faith of America is faith in God and man. She believes in brotherhood and opportunity. She believes in justice and mercy.

America has received from all races. She gives to all races. One bond binds all races together in her citizenship. It is the bond of loyalty. To be an American is to love America; to believe in America; to serve America. To be an American is to live by the American ideals of freedom, honor, and service.

I thank God for the privilege of being a child of America. I pray that I may be worthy of the privilege. With gratitude and high purpose, for service with the heart, hand, and brain,

\section{AM AN AMERICAN. ${ }^{29}$}

${ }^{28}$ Ames and Eldred, op. cit., opposite p. 1; Reed, op. cit., p. 118; Ziegler and Jacquette, op. cit., p. 7 .

${ }^{29}$ Bryant, op. cit., pp. 161-62. Many references might be given on the spirit of loyalty and how to show loyalty to country, obligations to the government for its protection, and similar topics. See, for instance, Munro and Ozanne, op. cit., p. 72; Woodburn and Moran, op. cit., pp. 27-28; Finch, op. cit., pp. 157, 295-98; Binford, The Young American Citizen, pp. 294-97; Hughes, Text-Book in Citizenship, p. 701; Ashley, op. cit., p. 33; Dole, op. cit., p. 367; Shepherd, The Boy's Oren Book of Politics, p. 9; Morehouse and Graham, American Problems, p. 494; Turkington, My Country, pp. 68-73; Reed, Loyal Citizenship, p. 74; Dunn, op. cit., pp. 56-57, 75-76. 

PAR'T III

TEXTBOOKS IN GEOGRAPHY 



\section{CHAPTER XVII}

\section{THE UNITED STATES AND PEOPLES OF OTHER COUNTRIES}

\section{CHARACTERISTICS OF OTHER PEOPLES}

Geography textbooks portray far less of controversial issues than do the histories and other social study books commonly found in the American public school. When they depart from a discussion of physical features, geography textbooks deal largely with trade relations and the customs of the people, and then in such a way as to make for mutual understanding and tolerance. Some geographies trace the descent of the people of the United States, showing the influence of various nationalities upon American political and social institutions and life. In fact, a number of authors aver in the preface of their books a desire to stimulate the reader's interest in the life of people of countries other than America. ${ }^{1}$ On the whole, far less material tending toward civic education is found in geographies than in other books surveyed in this study.

It is the obvious effort of some authors to create a tolerant attitude, for they frequently point out at length that a custom which seems "strange" to us is not "strange" to all peoples, and that many American practices would appeal to other nations as peculiar as theirs appeal to us. For example, Huntington says:

In reading about strange customs we must remember that the fact that they are strange to us does not mean that they are not as good as our own. Some are doubtless worse than ours, many are equally good, and some are better. For instance, in readiness to learn from others the Japanese far surpass us; while in patient economy and industry the Chinese are so far our superiors that we have as much to learn from them in those respects as they have to learn from us in other ways. ${ }^{2}$

${ }^{1}$ For example, Blaisdell and Blaisdell, Child Life in Many Lands.

${ }^{2}$ Huntington, Asia, p. 24. See also for a similar point of view Morris, Home Life in All Lands, Book I. 
Fairgrieve and Young have a like point of view:

We have no right to laugh at other people's clothes, their food or their houses, because these things are not like ours. We have to learn that other people are as good and wise as we are, and that if their ways seem strange to us, ours seem just as funny to them. We like sugar, an Eskimo boy likes fat, and an African child likes salt. If we were Eskimos we should think it fine to eat candles, but because we are Americans we would much rather have candy. ${ }^{3}$

People differ from each other in race, in color, and in the kinds of places in which they live [declares Smith in his Human Geography]. Yet all mankind is alike in having six needs [food, fuel, shelter, clothes, tools, luxuries]. In having these six needs all men are brothers. ${ }^{4}$

Not only do nations hold in common certain needs, but due to systems of transportation, all nations today seem near neighbors, with the welfare of all mutually dependent. The higher the civilization, the greater the interdependence is the conclusion of Packard and Sinnott. ${ }^{5}$ Furthermore, "each nation has something to teach the others." 6

As we turn to statements relating to the Europeans in general, geography textbooks describe them as belonging "to the most highly civilized of all the world's peoples," the people of the mother-continent, and the teacher of most of the world. "Most of the best books, music, paintings, and sculpture have come from Europe," assert Tarr and McMurry. ${ }^{8}$

Europeans and their descendants dominate most of the world [states Whitbeck]. European civilization has spread over the earth; it seems to have won because of its superiority. . . . . Most Europeans were barbarians when we first know of them; and from this condition of barbarism they have been changed into the most enlightened and most masterful people in the world. ${ }^{9}$

${ }^{3}$ Fairgrieve and Young, Human Geography by Grades, Homes Far Aray, Book II, p. 10.

"Smith, Human Geography, Book II, p. 1.

${ }^{5}$ Packard and Sinnott, Nations as Neighbors, pp. 4-5.

${ }^{6}$ Ibid., p. 14. $\quad{ }^{7}$ Carpenter, Europe, p. 17.

${ }^{8}$ Tarr and McMurry, Nere Geographies First Book, pp. 187-88.

'Whitbeck, High School Geography, pp. 501-2. 
They are characterized as energetic and competent; and "they have written more books than all the rest of the people of the world." $" 10$

Among the foremost of these peoples are the English, pictured as intelligent, ingenious, industrious, and progressive, with a natural fondness for exploration, trade, and industry. "Notwithstanding its small size, the United Kingdom is in many respects the most powerful, and the most important in the world," declare Tarr and McMurry. "It carries on more foreign commerce than any other nation, it has more and larger colonies, and in it is London, the largest city in the world."12 In government England is held "remarkably liberal and adaptable, conservative enough to prevent hasty changes, yet always able to change when the need of change is clear." Its people have a genius for business, for colonization, and for diplomacy. "The Englishman never knows when he is beaten, and, as a consequence, he has won almost every great conflict in which he has engaged. The stubbornness and persistence of the British are proverbial."13

"In the extent and importance of its dependencies" there is "no other nation that compares with Great Britain," say McMurry and Parkins. ${ }^{14}$ They believe, "moreover, the British have in general kept the loyalty of their colonies through good government," 15 India being cited as a case in point of the improved condition of that country since British occupation. ${ }^{16}$

Blaisdell and Blaisdell bring up a Revolutionary War incident of the General Gage régime in Boston which recalls Anglo-American discord, but few of the books follow that line of treatment. ${ }^{17}$

${ }^{10}$ Smith, op. cit., Book I, p. 276.

${ }^{11}$ Packard and Sinnott, op. cit., p. 275. See also Smith, op. cit., Book II, p. 215; Tarr and McMurry, Nere Geographies Second Book, p. 276.

${ }^{12}$ Tarr and McMurry, Nere Geographies First Book, p. 189. See also Robinson, Commercial Geography, p. 398.

${ }^{13}$ Whitbeck, op. cit., p. 468. See also Robinson, op. cit., p. 398.

${ }^{14}$ McMurry and Parkins, Advanced Geography, p. 293.

${ }^{15}$ Ibid., p. 294.

${ }^{18}$ Ibid., p. 407. See also Carpenter, Asia, p. 281. The same statement is made about Egypt in Robinson, op. cit., p. 348.

${ }^{17}$ Blaisdell and Blaisdell, op. cit., pp. 29-31. 
Indeed, the general opinion of authors of geography textbooks is that "the English-speaking peoples have risen to a commanding place among the nations, and if the highest ideals of these peoples can prevail their leadership will benefit the world." 18

To the French are attributed the qualities of intelligence, thrift, artistic taste, and culture. ${ }^{19}$ According to Robinson

The French people are generally conceded to be among the most patriotic and united in Europe. They have an artistic instinct which imparts beauty to whatever they touch, and great thrift which enables them to prosper in spite of a huge standing army, and a public debt without parallel, and enormous taxes. ${ }^{20}$

"In many respects" they are said still to hold "an advanced position among European peoples," due not so much "to the magnitude of their undertakings" as to their "intellectual and artistic qualities." 21 Huntington, in his book on Asia, questions the wisdom of French colonial policy, suggesting that in some respects it has hampered the development of the colonies. ${ }^{22}$

The Germans are considered among "the most intelligent and industrious of the world," "always ready to fight and work for a great share of all that the world has to offer." Indeed, the American "always finds them among our chief competitors in manufacture and trade." 23 According to Smith, "nearly everybody in Germany can read and write, and there are fine universities and trade schools in many of the cities."24 Among Germans are found the foremost scientists and musicians. ${ }^{25}$

The World War, according to McMurry and Parkins, cost Germany "her former rank among the nations of the world."26 In the years before 1914,

Germany had become one of the greatest nations in the world. Had the nation continued its peaceful course it seems unquestionable that

${ }^{18}$ Whitbeck, op. cit., p. 499. See also Carpenter, Europe, p. 77.

${ }^{19}$ Tarr and McMurry, Nere Geographies Second Book, pp. 285, 287; Carpenter, Europe, pp. 98, 101; Smith, op. cit., Book I, p. 233, 234, 236.

${ }^{20}$ Robinson, op. cit., p. $390 . \quad{ }^{22}$ Huntington, op. cit., p. 294.

${ }^{21}$ Whitbeck, op. cit., pp. 514-15. $\quad{ }^{23}$ Carpenter, Europe, p. 221.

${ }^{24}$ Smith, op. cit., Book I, p. 239. See also Tarr and McMurry, Nere Geographies Second Book, p. 311.

${ }^{25}$ Smith, op. cit., Book I, p. 240.

${ }^{26}$ McMurry and Parkins, op. cit., p. 328. 
Germany would have become the leading nation of the world. But the warlike spirit and the ambitions of her ruling class plunged the world into the most terrible war of all time, and Germany emerged from it almost wrecked. . . . The old autocratic government had been overturned and a republic established; the immediate future is uncertain but the German people remain and will probably again become powerful in Europe. ${ }^{27}$

The German ability at organization and German militaristic tendencies are mentioned by some writers, as well as the invasion of Belgium, when "the Germans cruelly oppressed the Belgians." Because the latter were among "the competitors of the Germans in manufacturing and industry," it is alleged that Belgian industrial centers were ruined and the Belgian people left to starve. $^{28}$

Italian art, architecture, science, music, the influence of the Latin language and Roman law upon the civilized world are the chief contributions to history made by the Italians, according to the geographies. ${ }^{29}$

Of the characteristics of the Russians illiteracy seems to have impressed authors to the greatest degree. ${ }^{30}$ A "reverent" and oppressed people under the czarist régime and now under the Bolsheviki, the sympathies rather than the animosities of the reader are kindled by discussions in the geography textbooks. ${ }^{31}$

The Swiss are described as industrious, skilful, having an independent spirit expressed in the form of their government, and of "a high state of civilization." "32

${ }^{27}$ Whitbeck, op. cit., pp. 521-22. See also McMurry and Parkins, op. cit., p. 330 .

${ }^{28}$ Tarr and McMurry, New Geographies Second Book, p. 309; Robinson, op. cit., p. 418; Carpenter, Europe, p. 139.

${ }^{29}$ Packard and Sinnott, op. cit., pp. 397-401; Tarr and McMurry, Nere Geographies Second Book, p. 326.

${ }^{30}$ Robinson, op. cit., p. 430; Tarr and McMurry, Nerw Geographies Second Book, p. 304; McMurry and Parkins, op. cit., pp. 355-56; Smith, op. cit., Book I, p. 273; Packard and Sinnott, op. cit., pp. 421-22.

${ }^{31}$ Huntington, op. cit., p. 142; Smith, op. cit., Book I, p. 273.

${ }^{32}$ Smith, op. cit., Book II, pp. 251, 252; Brigham and McFarlane, Essentials of Geography: First Book; p. 202; Tarr and McMurry, Nere Geographies Second Book, pp. 320-21; Mirick and Holmes, Home Life around the World, p. 39; Carpenter, Europe, p. 261. 
In sharp contrast to descriptions of people like the Swiss are the larger number of discussions detailing the qualities of the Turk, whose object, it is said, seems to have been "to check progress as much as possible." "The Turks are "a fierce yellow race," who have "desolated" and "polluted" with "robbery and murder" one of the "fairest lands of the world." 35 They are "cruel and backward," and it is a gain to have freed European territory from Turkish control. ${ }^{36}$ As an example of their cruelty the Armenian massacres are mentioned..$^{37}$ Huntington and Carpenter remark on Turkish politeness and hospitality. ${ }^{38}$

Of the Danes, Finns, and Dutch the textbooks speak in high praise. To the Dutch are ascribed qualities of industry, excellent character, and a passion for education and liberty. ${ }^{39}$ Dutch cleanliness is frequently mentioned. ${ }^{40}$ The Danes are noted also for their thrift, industry, and education, as are the Belgians, Finns, and Scandinavians. ${ }^{41}$ A love of liberty is attributed to the people of Lithuania, Latvia, Poland, and Esthonia. ${ }^{42}$ The people of Iceland are said to "buy, read, and write more thoughtful books than the same number of people anywhere else." ${ }^{\text {43 }}$ The Eskimos are sometimes called "dirty" but Fairgrieve and Young suggest that "if we had no water, perhaps we should not be any cleaner."44 To the Irish is ascribed "a very great sense of humor,"

${ }^{33}$ Tarr and McMurry, Nerw Geographies Second Book, p. 337.

${ }^{34}$ Carpenter, Europe, p. 387. $\quad{ }^{35}$ Robinson, op. cit., p. 335.

${ }^{36}$ Tarr and McMurry, Nere Geographies Second Book, p. 337; Smith, op. cit., Book II, p. 264, Huntington, op. cit., p. 72.

${ }^{37}$ Huntington, op. cit., p. 83.

${ }^{38}$ Carpenter, Europe, p. 398; Huntington, op. cit., p. 83.

${ }^{39}$ Carpenter, Europe, p. 162; Tarr and McMurry, Nere Geographies Second Book, p. 278.

${ }^{40}$ Perdue, Child Life in Other Lands, pp. 68-69.

¿1 Tarr and McMurry, Nere Geographies Second Book, pp. 281, 300; Carpenter, Europe, pp. 141, 207, 212, 182; Smith, op. cit., Book II, pp. 231, 238, 242; Perdue, op. cit., p. 46; Packard and Sinnott, op. cit., p. 434.

${ }^{42}$ Smith, op. cit., Book II, p. 243; McMurry and Parkins, op. cit., p. 356; Packard and Sinnott, op. cit., p. 436.

${ }^{43}$ Smith, op. cit., Book II, p. 212.

" Fairgrieve and Young, op. cit., Book II, p. 17. 
and of those coming to the United States a great interest in politics and government. ${ }^{45}$

Turning to the Magyars and the Greeks, the reader finds in the former qualities of strength, bravery, patriotism, pride, and hospitality, and in the latter's country "the source of many of our own manners and customs," the "cradle of civilization." The Spanish and Portuguese are described as unprogressive, indolent though polite. ${ }^{46}$

The geography textbooks, in treating countries of Asia, point out that "Asia was the seat of some of the earliest civilizations of mankind." But "in spite of this early progress the Asiatic people have long stood still, while Europeans have been making rapid advances. In recent times, however, an awakening has begun. Some of the countries of Asia have already made astonishing progress, and others have begun to follow their example.",

Today Japan is the most civilized nation of Asia [says Huntington]. Indeed, in many ways Japan is the most civilized nation in the world. Europeans and Americans have made greater progress than Japan in inventions, manufactures, and commerce, but Japan is ahead of us in equally important matters, such as patriotism, filial respect, cleanliness, politeness, art and the love of nature. ${ }^{48}$

But "unfortunately the Japanese are forgetting some of their love of beauty, and are devoting much energy to the mad rush for wealth and business supremacy," the same author holds. ${ }^{49}$

Especially noteworthy are the Japanese qualities of politeness, love of the beautiful, intelligence, and patriotism..$^{50}$ As an example of their patriotism, a willingness to pay taxes and an

${ }^{45}$ Carpenter, Europe, p. 34; Smith, op. cit., Book II, p. 228.

${ }^{46}$ Tarr and McMurry, Nere Geographies First Book, pp. 212, 209; Carpenter, Europe, pp. 403, 305. For Spain and Portugal: Packard and Sinnott, op. cit., p. 391 ; Carpenter, South America, p. 85; Smith, op. cit., Book II, pp. 275, 261.

${ }^{47}$ McMurry and Parkins, op. cit., pp. 387-88.

${ }^{48}$ Huntington, op. cit., p. 193.

${ }^{49}$ Ibid., p. 198.

${ }^{\text {so }}$ Smith, op. cit., Book II, p. 319; Huntington, op. cit., pp. 215, 200, 217;

Brigham and McFarlane, op. cit., p. 232; Carpenter, Asia, p. 43. 
implicit obedience to law are contrasted with the attitude of Americans toward the same obligations. ${ }^{51}$

Today Japan, equipped with a powerful army and navy, an elective parliament, efficient public schools, and a ruling class educated in all modern arts and sciences, ranks with the Great Powers of the world, and is a dominating factor in all the problems of the Far East. There is no other example in history of such marvelous progress [declares Robinson]. ${ }^{52}$

When our ancestors were ignorant savages living in rude huts, the Chinese were already highly civilized. They lived in well-built houses, wore silk clothes, and knew how to read and write. They possessed schools, orphanages, and hospitals, and were governed peacefully and justly. Long before our ancestors thought of such things, the Chinese had devised the art of printing and invented gunpowder and the compass. They learned that the best way to settle quarrels was by arbitration rather than by blows [says Huntington].

After doing all this, the Chinese ceased to make progress, and have stood still for centuries. Europe and America, on the contrary, have progressed rapidly leaving the Asiatics far behind. To-day, however, the Chinese are beginning to wake up. In a few hundred years they may once more be far ahead of us, unless we learn to practice greater industry, patience, and economy, the three great virtues of China. ${ }^{53}$

Part of this backwardness is attributed by Huntington to China's dense population and frequent famines, which have caused both ignorance and poverty. ${ }^{54}$ Robinson likens China to "a house built of bricks without mortar," declaring that "her people, though rating life of little worth, are not brave in battle, and the family tie is so strong among them that public spirit or national patriotism can hardly be said to exist. China then appears badly equipped for the modern struggle for existence of

${ }^{51}$ Smith, op. cit., Book II, p. 319 ; Huntington, op. cit., p. 194.

${ }^{52}$ Robinson, op. cit., p. 301. See also Packard and Sinnott, op. cit., p. 470; Tarr and McMurry, Nere Geographies First Book, p. 225; Whitbeck, op. cit., p. 544; McMurry and Parkins, op. cit., p. 425.

${ }^{53}$ Huntington, op. cit., p. 221. See also Packard and Sinnott, op. cit., pp. 457-58; Tarr and McMurry, Nere Geographies First Book, p. 221, Second Book, p. 362; McMurry and Parkins, op. cit., pp. 413-15.

${ }^{54}$ Ibid., pp. 283, 232, 272. 
nations." Y55 "as the Chinese have come into closer contact with the people of America and Europe they have gradually given up many of their old national customs, and they are becoming more and more like ourselves in dress and habits," declares Carpenter. ${ }^{56}$

Toward this country the United States has adopted a policy of friendship, authors assert. "It has taken a vigorous stand in preserving her territory and independence. America has been China's best friend among the nations." 57

Although it is believed that the Mexicans are lacking in a capacity to develop the resources of their own country or to establish a stable government, nevertheless it is conceded that "the upper class of Mexicans includes people of high education, refinement and wealth." ${ }^{958}$ Most of the natives are said to be ignorant Indians of mixed blood, and more than 50 per cent of the adults are "unable to read and write." The difficulty of protecting the border line between Mexico and the United States from marauding Mexican bands is mentioned by some authors. ${ }^{60}$ The desirability of cultivating friendly relations between the two countries is stressed, particularly by McMurry and Parkins. ${ }^{61}$

Our neighbors of the South American continent receive kindly treatment, on the whole, by the geographers. The Venezuelans are characterized as "hospitable," the Chileans as "vigorous and brave," the Peruvians as "polite and especially cordial to strangers," the Colombians as gentle and "hospitable."

The encouragement of friendly relations from a commercial standpoint is the plea of some of the textbooks. As Whitbeck, in his High School Geography, says:

The United States and South American countries ought to maintain close and friendly relations. The tropics produce things which

${ }^{55}$ Robinson, op. cit., p. $310 . \quad{ }^{68}$ Carpenter, Asia, p. 197.

${ }^{57}$ McMurry and Parkins, op. cit., p. 419. See also Carpenter, Asia, p. 146.

${ }^{s 8}$ Whitbeck, op. cit., p. 428.

${ }^{50}$ Smith, op. cit., Book I, p. 185; McMurry and Parkins, op. cit., p. 199.

${ }^{\text {Bo }}$ Ibid. ${ }^{\text {e1 Ibid. }}$

${ }^{82}$ Carpenter, South America, pp. 44-45, 90, 135-36, 378; McMurry and Parkins, op. cit., pp. 268, 271. Brazil is discussed in ibid., pp. 257-58. 
we need in ever increasing quantities . . . . Moreover, South America depends upon, outside countries for most of its coal, petroleum, machinery, and manufactures of all kinds. These we can supply and ought to supply as we are now doing. ${ }^{63}$

The island possessions of the United States are said to have improved materially and spiritually under the tutelage of the Americans. In this respect, the geographies do not depart much from the point of view presented by the histories. ${ }^{64}$

\section{TRADE AMONG NATIONS}

The influence of trade in cementing relations among peoples of varied and diverse interests is discussed in many of the textbooks examined. According to Smith

The world is one. Trade has made it so. The different parts of the world are now connected. No longer do most of the families of the world live apart from other families. ... . Ships, railroads, telegraphs, and machines have made the people of many lands our helpers. Each country now has something that we buy. Trade has also made us helpers to many other people. We help them by selling to them the things that they want. ${ }^{65}$

Therefore, the pupil is shown, in his reading of such textbooks, that the United States contributes to each country, and other countries give to the United States necessities and luxuries which otherwise would be lacking.

"We see men [In France] plowing the battlefields with American steam tractors." Belgium gets "food stuffs from the United States, iron from France, and rubber, ivory, palm oil and other products from its great colony, the Belgian Kongo in Africa." On the other hand, "a great deal of Belgian plate glass is exported to the United States." We take "much Belgian rubber, which is brought from the Belgian Kongo to Antwerp and sent from there across the Atlantic Ocean to us." "We furnish Gerstudy.

${ }^{83}$ Whitbeck, op. cit., pp. 463-64. Quoted also in a later portion of this

${ }^{64}$ Brigham and McFarlane, op. cit., p. 153; Packard and Sinnott, op. cit., p. 230; Smith, op. cit., Book II, pp. 194-95; McMurry and Parkins, op. cit., pp. 200, 173, 431-34; Robinson, op. cit., p. 224.

${ }^{\text {es }}$ Smith, op. cit., Book II, p. 10. 
many three-fourths of its cotton, nine-tenths of its copper and much meat, especially lard. Before the World War we bought more of Germany than of any other country except Great Britain." Furthermore,

Germany makes laces and embroideries and exports to the United States millions of dollars' worth of machine-made lace. It has vast cotton mills fed by our Southern plantations and woolen mills that export their goods to all parts of Europe and the United States. The sheep of Saxony .... have fine wool, and in our dry goods stores one can buy the beautiful Saxony yarns used for crocheting and knitting. ${ }^{66}$

From the Swiss, "vast quantities" are said to be exported to the United States, so that "tens of thousands of Swiss men, women and children" are kept busy working "to supply the American market with certain kinds of goods." "67 From the United States Switzerland buys

much of the copper and other metals used in her electrical machinery, and a great deal of the raw cotton employed in making her beautiful embroideries, curtains and laces. .... We sell her petroleum, flour, meat, and various food stuffs. At the same time we are the best customer of all the nations for Swiss embroideries. ${ }^{68}$

From Italy the United States imports "quantities" of macaroni and raw silk; from Russia, caviar; from Czechoslovakia, horns, violins, and musical toys; as well as things from Bohemia. ${ }^{69}$

So far as South America is concerned, the United States and the countries of that continent

ought to maintain close and friendly relations. The tropics produce things which we need in ever increasing quantities . . . . Moreover, South America depends upon outside countries for most of its coal, petroleum, machinery, and manufactures of all kinds. These we can and ought to supply as we are now doing. Many American banks have already been established in Latin America . . . . and a cordial feeling exists between the United States and most South American countries. ${ }^{70}$

${ }^{\text {B8 }}$ Carpenter, Europe, pp. 135, 141, 147, 223, 240.

${ }^{67}$ Ibid., p. 261.

${ }^{68}$ Ibid., pp. 263-64.

${ }^{69}$ Ibid., pp. 376, 430, 443.

${ }^{70}$ Whitbeck, op. cit., pp. 463-64. 
Many of our farmers use the nitrates from the South American desert to fertilize their crops. Our finer rubber comes from the wild trees of the Amazon basin, and almost all the coffee we drink is grown in Brazil. The most of our chocolate comes from the cocoa trees of Brazil, Venezuela, Colombia, and Ecuador. .....We import wool and meat from the Rio de la Plata basin. We get some of our tin from Bolivia, and considerable copper from Peru and Chile. We have diamonds from Brazil and emeralds from Colombia. Indeed, there is hardly a state of South America that does not supply us with materials of one kind or another, and .... South Americans are using more and more of the things we raise and the manufactures we make for export to other nations. ${ }^{71}$

Besides these American products, Carpenter enumerates others being used in South American countries, such as canned meats, typewriters, automobiles, motor trucks, and phonographs. On the other hand, we buy coffee, beef extract, raw wool, cattle, borax, nitrate of soda, iodine, sugar, rice, and other things. ${ }^{72}$

In Asia, Carpenter tells his readers, "at nearly every port ships filled with American goods may be found, while other ships are starting out with exports for the United States." ${ }^{\text {"73 }}$ Japan, in particular, has an "enormous trade" with the United States. From there we get tea and silk. In fact, the United States is Japan's "best customer in silk."

The trade between the United States and Japan is increasing and she sells more and more manufactured goods to us every year. On the other hand, we are shipping to Japan many different kinds of machinery. She buys our chemicals, dyestuffs, and leather, and our cars and locomotives for her railways. We send her flour and wheat, and all sorts of manufactures in iron and steel. We send her minerals of various kinds, and we furnish the gasoline used in her automobiles and gas engines, and the kerosene in her lamps. Most of the Japanese are clad in American cotton, and millions of them depend for their living upon the work they have in making into manufactured goods the raw materials supplied by the United States. ${ }^{75}$

${ }^{71}$ Carpenter, South America, pp. 18-19.

${ }^{72}$ Ibid., pp. 130, 133, 99-100, 129, 278, 202, 205, 138, 145, 388.

${ }^{73}$ Carpenter, Asia, pp. 20-21. $\quad{ }^{74}$ Ibid., pp. 43, 92.

is Ibid., pp. 101-2. 


\section{THE UNITED STATES AND OTHER COUNTRIES 187}

From China come duck eggs and tea, and in Shanghai there are many oil works and tobacco factories said to belong to Americans. According to Carpenter, many Americans live in China to "manage the trade between the two countries." $\mathrm{He}$ also discusses the "great trade" carried on between Calcutta and the United States, mentioning especially the export of linseed oil to this country. ${ }^{77}$

In spite of the vast extent of our industries, we are by no means independent of other nations [declare McMurry and Parkins]. We should suffer less from hunger than many of them, even if there were no foreign trade; but we could hardly be prosperous. Every one of our states is dependent upon the others in scores of ways; and in much the same manner any one nation is dependent upon others. ${ }^{78}$

${ }^{76}$ Ibid., p. 170.

${ }^{77}$ Ibid., pp. 275, 325.

${ }^{78}$ McMurry and Parkins, op. cit., p. 472. 


\section{CHAPTER XVIII}

\section{THE ACHIEVEMEN'TS OF THE UNITED STATES}

There is little "jingoism" or braggadocio in geography textbooks, although there are mentioned the prosperity and riches of this country, the helpfulness of America to the oppressed, the benefits of democracy, and the valor and fortitude of our forebears.

"There is, perhaps, no country on earth where an honest man, with ability and energy, can prosper so easily as in the United States," declare Tarr and McMurry. ${ }^{1}$ Indeed, according to Smith,

It is . . . a very good country in which to live to make a living. The people of the United States are fortunate. The climate is good, so that most of the people are strong and healthy and want to do things. . . . . In some countries they are not as healthy as they are in the United States. . . . .

Besides being fortunate in having a good climate, our country is rich in the materials needed by man for food, clothes, shelter, fire, power and machines. People like to come here to live because good wages can be paid in a country so rich in the thing which men need. . . . .

We have over one hundred million people in this great country of ours, but there is enough land for us all. We feed ourselves and have much food to spare. This surplus we can send to the people in other countries. There is much land in the United States that we do not yet use for crops. ${ }^{2}$

Everywhere abundant resources are found to have been turned to advantage by man's hand and brain. ${ }^{3}$ This remarkable development is due "in large part," it is said, to the many devout, industrious, and thrifty people who first settled here. Most of them were men and women of strong character who thought more of doing right themselves and training their children properly than they did of gaining wealth. That they might carry out their

${ }^{1}$ Tarr and McMurry, Nere Geographies First Book, p. 107.

${ }^{2}$ Smith, Human Geography, Book I, pp. 46-47, 258. See also Knowlton, First Lessons in Geography, p. 1.

${ }^{3}$ Lefferts, Our Own United States, p. 331. 
high purposes, they left their homes and friends to live in a wilderness across the Atlantic where the conditions of life were very hard. "We owe much to their sacrifices. Their high ideals, passed on from generation to generation, have done much to make this land of ours one of the best places in the world in which to live."

McMurry and Parkins also agree in their statements with othe $f$ writers concerning American prosperity. "The United States is the wealthiest nation in the world, and also the greatest in manufacturing," they declare. "Since the leading countries of Europe have been so impoverished by the World War, our advantage in wealth is very great."

The opportunity "to make a living" and "to be free" has prompted many people to leave their native land for America, if we read the textbooks aright. ${ }^{6}$ For is not America "a treasure house of wonderful riches" ?7 'Then, too, the government is a "democracy" in which "all the officers are thus really servants of the people, and not their masters, and they are paid for their work by the people." The object of this government is "to help every one, as far as possible and not to worry or oppress anyone."

Another advantage in living in the United States, according to the authors of geography textbooks, is the opportunity for free education open to all. "Our excellent system of education is one of the chief causes of our rapid advance, for educated people can do things which ignorant people cannot do," is the belief of Tarr and McMurry. ${ }^{\circ}$

As a gesture toward protecting weaker nations, the Monroe Doctrine is said to have been announced and applied in various

4 Packard and Sinnott, Nations as Neighbors, p. 57. See also Robinson, Commercial Geography, p. 196.

'McMurry and Parkins, Advanced Geography, p. 276.

${ }^{\circ}$ Smith, op. cit., Book II, p. 266. See also Packard and Sinnott, op. cit., pp. 59-61.

${ }^{7}$ Carpenter, North America, p. 18. See also Carpenter, Europe, p. 174.

${ }^{8}$ Tarr and McMurry, op. cit., pp. 80, 107. See also Carpenter, Asia, p. 462 .

- Tarr and McMurry, op. cit., p. 107. 
instances since $1823 .^{10}$ The Pan-American Union has been a development of the spirit of kinship which is said to have grown between the two American continents. ${ }^{11}$ Through the Union peace has been promoted and war eliminated. And the writers of geographies, on the whole, believe that this is wise.

War is the enemy of trade and commerce. It blocks harbors and curtails the freedom of the seas. It alters the purchasing power of money and causes great disparity of prices in the markets of the world. It strikes at the heart of industry and discourages the production of all things not essential to carrying on the conflict. In its destructive course it draws out of the world's storehouse much of the wealth accumulated by the efforts of mankind through successive ages. $^{12}$

The need of preparedness is touched upon by Carpenter in his North America. ${ }^{13}$ Arbitration and the formation of some association of nations as a means of settling international controversies are advocated by Packard and Sinnott and McMurry and Parkins. ${ }^{14}$

The advantages and attractions of America, it may be said in closing, are attested to, according to the textbooks, by the large number of immigrants seeking admittance to this country. "When they land here, few of them know our language, but they soon learn to speak it," declare Brigham and McFarlane. "They send their children to our schools, they work hard, and they become useful citizens."15 According to Packard and Sinnott, "All of these newcomers have aided in the development of our country"16 - "the most important country in the Western Hemisphere . . . . in many ways the leading country in the world."17

${ }^{10}$ McMurry and Parkins, op. cit., p. 276; Allen, South America, p. 6.

${ }^{11}$ McMurry and Parkins, op. cit., p. 276. See also Allen, op. cit., p. 6.

${ }^{12}$ Robinson, op. cit., p. 456. See also Knowlton, op. cit., p. 238; McMurry and Parkins, op. cit., p. 389; Carpenter, North America, p. 41.

${ }^{13}$ Carpenter, North America, pp. 41, 152-53.

${ }^{14}$ Packard and Sinnott, op. cit., p. 11; McMurry and Parkins, op. cit., p. 381.

${ }^{15}$ Brigham and McFarlane, Essentials of Geography First Book, p. 184. See also Tarr and McMurry, Nere Geographies Second Book, p. 331.

${ }^{16}$ Packard and Sinnott, op. cit., pp. 58-59. See also Tarr and McMurry, New Geographies First Book, p. 107.

${ }^{17}$ McMurry and Parkins, op. cit., p. 25. 
PART IV

READERS 



\section{CHAPTER XIX}

\section{THE UNITED STATES AND OTHER NATIONS}

\section{GENERAL CHARACTER OF MATERIAL IN READERS}

Readers, like histories, contain much material having an emotional appeal. Indeed, many of the textbooks in reading, published during the World War, were designed to stimulate the emotions of that great conflict, and to stir the patriotic pulse by the narration of heroic exploits and national achievements of the allies in arms, especially of America. The same effect was accomplished by uncomplimentary and sometimes untrue statements regarding the enemy peoples. Some of these readers still appear in the lists of approved textbooks of city systems and of state adoptions. Frances Nimmo Greene's My Country's Voice may be used as an illustration.

The Table of Contents can be cited to show the topics discussed: "To the Young American," "A Bit of History," "Warren's Address to the American Soldiers," "Henry's Appeal to Virginia," "English Defense of the Colonies," "The Minuteman of the Revolution," "The Concord Hymn," "George Washington," "Washington," "Lafayette-The Friend of America," "Spirit of the Declaration of Independence-Liberty-Justice," "The Story of a Flag," "How To Treat the Flag," "About Our Constitutionthe Foundation of Our Laws," "The Story of a Song," "America the Beautiful," "The Opportunities of Democracy," "The Monroe Doctrine," "Pioneers! O Pioneers!" "A Nation of Pioneers," "The Bivouac of the Dead," "Disunion and War," "To Save the Union," "Little Giffen," "Gettysburg Address," "About the Battle Hymn," "The End of the Brothers' War," "O Captain! My Captain!" "Repledging the South to the Union," "The Blue and the Gray," "Old Ironsides," "Lincoln-the American," "Leethe American," "America for Me," "A Precedent," "For Cuba," "High Points," "True Americanism," "The Homes of the People," "Home, Sweet Home," "America Wakes," "Germany's Sins 
against America," "The War Message," "Old Ties Renewed," "The Ship of State," "Soldiers of Freedom," "A 'Toast," "Loyalty," "The Nation in Arms."

The titles are, in most cases, descriptive of the contents. They are preceded by a picture of a Red Cross nurse, whose background is the American flag, and in front of whom stand an American marine and a soldier. Surrounding them are people with outstretched arms, as if pleading for help. Beneath the picture is this verse:

Content to find where'er her flag shall wave Thy glory or thy grave!

In comparison, the Table of Contents in one of the LymanHill Junior High School series, Literature and Living, is given. Although this series contains selections bespeaking loyalty to country, it has also excerpts of readings from authors who are attempting "to interpret life" in its social setting. Book I of the series is divided into the following parts : "I. Making Homes," "II. Going to School," "III. Finding Enjoyment," "IV. Providing Safety," "V. Seeking New Homes," "VI. Making the Best of One's Self."

Part I deals with "The Dwelling Place," "The Home Circle," "Glimpses into a Few Homes," and "Family Ties and Home Obligations." Part II takes up "Schools and Schooling of Long Ago," "Overcoming Difficulties for an Education," "Sports and Sportsmanship in School Life," and "Glimpses of Education and School Life." Part III treats "Joy in the Out-of-Doors," "Beauties of Nature," "Trees," "Sports, Amusements, and Games," and "Happiness, Cheerfulness, and Contentment." Part IV discusses "Safety from Fires and Floods," "Maintaining Law and Order," and "Safeguarding Health." Part V deals with "Visions and Purposes of Newcomers to America," "Experiences of New Americans," "What the Newcomers Bring to America," and "What America Should Mean to True Citizens." Part VI presents materials on "The Highest Success," "The Material with Which We Build," "Carrying Hard Tasks Through," and "Personal Growth." 
FRANCE IN THE READERS

Readers, in general, conform to the general characteristics of content in the history textbooks. France, therefore, is depicted as a friend of America to whom a debt of gratitude is owed. "Your admiration for France will grow as you study history and learn what she has done to help in the struggle for Freedom, Brotherhood, Equal Right," declare Lewis and Rowland. ${ }^{1}$

Stories of the World War carry out the same idea and, in contrast to those told of Germany, paint France a martyr and an example of nobility. The following story of two little French orphans living in a big orphanage in France will serve to illustrate. Leon was ten years old; Marcel was a baby.

So very long it seemed to Leon now, since his dear father, dressed in the wonderful blue soldier clothes, had marched down to fight for France, their beloved country. And then afterwards, when word came that a cruel German shell had killed him, the dear little mother had grieved herself to death-and that is why Leon and baby Marcel lived in the orphanage. But Leen remembered well the day his mother called him to her side and placing her hand on his head, said with a smile, "You are mother's big, strong boy! I am going away from you, Leon; take good care of Marcel. She will have only you now to keep her from harm."

Leon had said to his mother: "I am going to be a soldier and fight for France, and I shall kill the Germans too, because they shot my father and made you sick. ....."

And then came the day of horrors to the little French villagea day when German raiders rode pell-mell through the peaceful streets, entered the homes, carried away all food, wine, clothing, furniture, silver, jewelry; and then setting fire to the houses, shot in their tracks those who fled in panic into the streets.... [Then Leon rescues Marcel.]

A few yards more and he would be safe and then-bang! bang! The shots seemed to fall over and all about him, and with a dull thud poor little Leon dropped to the ground, baby Marcel beneath him. . . . [ [Then] bounding through the strip of woods came a big American soldier ... as the little group turned towards the

${ }^{1}$ Lewis and Rowland, The Silent Readers Eighth Reader, pp. 267-68, "The Name of France." 
pretty Orphan's Home, the roof fell in with a crash as the flames shot high in the air. "Beasts!" muttered the khaki soldier. "Three of them at least will burn no more villages or shoot babies either. I got here just in time to send them shot for shot."2

Another story carrying the theme of American-French friendship is that of "Joan and Pierre." Joan and Pierre were two little French children who lived in a small village which had been "torn to pieces by the guns of the Great War."

"Oh, Joan!" said Pierre, "What a beautiful new coat you have." Then Joan took Pierre to the place where she got her coat. Over the house floated an American flag which Joan said her father told her had made him very happy the first time he saw it in the trenches. Pierre went into the house and was given nice, warm clothes, a pair of shoes and a cap and some food. It was the house of the Junior Red Cross. "The little boys and girls of America send us these things," said Joan. ${ }^{3}$

Even the dogs in France during the World War received eulogy. Under the title of "The Smallest Soldier of All," Lewis and Rowland, in their Fifth Reader, tell the story of a dog, "Mignon," the pet of a French soldier, which carried an important message through battle-fire and thereby saved France."

In the World War, the Americans renewed "old ties" with the nation which had sent Rochambeau and Lafayette to aid in a struggle for liberty..$^{5}$ Indeed, recalling the coming of Lafayette, "the friend of America,", who came to aid us in "the establishment of the great public principles of liberty," it is pointed out how difficulties beset him.

${ }^{2}$ Lewis and Rowland, The Silent Readers Fourth Reader, pp. 7-12.

${ }^{3}$ Elson Readers Book Tro, pp. 154-57. See for "A Brave Little Frenchman," Lewis and Rowland, Fourth Reader, pp. 204-7.

${ }^{4}$ Lewis and Rowland, The Silent Readers Fifth Reader, pp. 132-33. Found also in Lincoln Readers Fourth Reader, pp. 263-65.

'Greene, My Country's Voice, pp. 137-38.

'Ibid., p. 29.

'Baker and Thorndike, Everyday Classics Seventh Reader, pp. 162-63. See also "The Lafayette Rose," in Heart of America Readers Fifth Reader, pp. 126-33. 
You may well believe that the kind and all the other high-andmighty ones by whom the young marquis was surrounded did not share in his sympathy for liberty. .... Lafayette had to steal out of France in disguise and set sail from a Spanish port in a vessel bought for the purpose with his own money.

He came! He helped us to conquer!.... And it was chiefly due to him-who came to the help of America when he had to run away to do it-that the government of France later sent over a considerable land force under the Count de Rochambeau, and a fleet of warships to aid in the struggle for American Liberty. . . . .

We Americans love to remember that Lafayette went back to France, and there helped to establish-after the pattern of America - the glorious Republic of France.

Vive La France! ${ }^{8}$

\section{GERMANY IN THE READERS}

In sharp contrast to the reading of excerpts from prose and poetry extolling the virtues of France are those relating to Germany. Not only are the military tactics of the Germans condemned, but the educational policies and the general characteristics of social and political life come in for criticism.

How was it possible for the ruling class in Germany [during the World War] to hold seventy million people to a war program which subjected them to so much suffering and sacrifice [Lewis and Rowland ask]? By far the most satisfactory answer to this question is to be found in the organization of the German schools as they were before the World War. Indeed, the striking contrasts between autocracy and democracy are at no point more clearly revealed than in the differences between the Imperial German system of education and a democratic system like the United States. ${ }^{9}$

To tell the complete and unconscious subjection of the German soldier to the military system is the purpose of "Catching a Spy." According to the story, during the World War a German naval

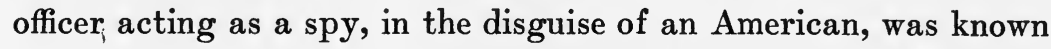
to be trying to return to Germany through London and Holland. The story tells how the spy had nearly convinced the investigator

${ }^{8}$ Greene, op. cit., pp. 31-33.

${ }^{\circ}$ Lewis and Rowland, The Silent Readers Eighth Reader, pp. 88-93. 
that he was the wrong man, when suddenly the admiral shouted to him in German:

"How dare you stand, like that when you are speaking to a superior officer?"

The suspect straightened his back, his heels clicked, and his hand was half way up to the salute before he could control himself. It was then too late, and after the arrest the proofs were found. The admiral knew that, if the man were surprised, no exercise of will could prevent him from responding to an order in the typical manner of a German officer. ${ }^{10}$

It was against such a system that it is alleged that America entered the World War. Indeed, just as we had warred against the "oppressive rule" of George III, who in reality was "a German, who had the same absurd ideas of the divine right of kings that Kaiser Wilhelm had," so we engaged in the World War against Kaiser Wilhelm for democratic principles to be maintained throughout the world. ${ }^{11}$

The blame for the War is clearly fixed upon Kaiser Wilhelm and his immediate associates. According to Baldwin,

The last great conspiracy against democracy and human liberty originated in the German empire and was planned and conducted chiefly by the Kaiser, William Hohenzollern, and his officers and subordinates. From the time of his accession to the throne, the Kaiser's chief ambition was the attainment of world empire, the exaltation of himself as the "All-Highest," or the supreme ruler by divine right, and the suppression and overthrow of democracy. ${ }^{12}$

At another point, Baldwin continues the theme:

You know the results [of the World War] .... and how by the treaty of peace many peoples hitherto helpless and enthralled were awarded the priceless gift of freedom. The forces of autocracy had been routed and overthrown. The world would henceforth be safe for democracy. LiBerTy was triumphant. ${ }^{13}$

In the reproducing of documents like the President's Address to Congress, April 2, 1917, many readers carry for the upper

${ }^{10}$ Lewis and Rowland, The Silent Readers Seventh Reader, p. 237.

${ }^{11}$ Ibid., pp. 291-95.

${ }^{12}$ Baldwin, The Story of Liberty, pp. 235-36. $\quad{ }^{13}$ Ibid., pp. 239-40. 
grades the same ideas as those given in story form for younger children. But undoubtedly the poetry and prose directly relating the hardships, sacrifice, and achievements of the fighting forces have the most pronounced effect on the pupils who read them. Such are poems like "In Flanders Fields," appearing in several of the readers. ${ }^{14}$

In Flanders fields the poppies blow

Between the crosses, row on row,

That mark our place; and in the sky

The larks still bravely singing fly,

Scarce heard amidst the guns below.

We are the dead. Short days ago

We lived, felt dawn, saw sunset glow,

Loved and were loved, and now we lie

In Flanders fields.

Take up our quarrel with the foe.

To you, from failing hands, we throw

The torch. Be yours to hold it high!

If ye break faith with us who die

We shall not sleep, though poppies grow

In Flanders fields.

Then follows, in some of the books, "The Pledge" and "The Fulfillment," reproduced here to show the character of the poetry of the World War period.

\section{AMERICA'S ANSWER}

Rest ye in peace, ye Flanders dead, The fight that ye so bravely led

We've taken up. And we will keep

True faith with you who lie asleep

With each a cross to mark his bed,

${ }^{14}$ Elson Readers Book Seven, p. 496; Lewis and Rowland, The Silent Readers Eighth Reader, p. 3; Hartwell, Story Hour Readings Fifth Year, p. 304; Fryer, The Young American Readers Community Interest and Public Spirit, p. 277. 
And poppies blowing overhead,

Where once his own life blood ran red.

So let your rest be sweet and deep

In Flanders Fields.

Fear not that ye have died for naught.

The torch ye threw to us we caught.

Ten million hands will hold it high,

And Freedom's light shall never die!

We've learned the lesson that ye taught

In Flanders Fields. ${ }^{15}$

THE FULFILLMENT

In Flanders fields the poppies bloom Above your lovely, hallowed tomb, That your brave deeds may never die. The torch of freedom lifted high Shall shine forever where you lie. No more in Flanders fields will grow The crosses, endless row on row, For crushed and conquered lies the foe.

We kept the faith-We've seen it through, Our myriad dead lie dead with you In Flanders fields.

Sweet be your rest! Our task is done; The tramp of armies, boom of gun And furious cry of savage Hun Are silent now. The victory's won!

Peace to your souls! The victory's won In Flanders fields. ${ }^{16}$

Another poem, which can in no degree stir anything but hate for Germany in the pupil who reads it, is "War's Recompense," taken from the National School Service by authors of readers. This poem is said to have been found on the body of an unknown

${ }^{15}$ Hartwell, op. cit., p. 305; Elson Readers Book Seven, p. 476; Lewis and Rowland, The Silent Readers Eighth Reader, p. 4.

${ }^{16}$ By Rev. J. A. Williams, Lewis and Rowland, The Silent Readers Eighth Reader, pp. 5-6. 
Australian soldier who died on the Western front of France during the war.

Ye that have faith to look with fearless eyes

Beyond the tragedy of a world at strife,

And know that out of death and night shall rise

The dawn of ampler life,

Rejoice, whatever anguish rend the heart,

That God has given you a priceless dower,

To live in these great times and have your part

In freedom's crowning hour;

That you may tell your sons who see the light

High in the heavens-their heritage to take-

"I saw the powers of Darkness put to flight;

I saw the morning break." 17

\section{ENGLAND IN THE READERS}

Since the World War the readers have mirrored a new and affectionate regard for England. A sense of kinship of Englishspeaking peoples has become articulate. As Washington Allston has put it in his poem "America to Great Britain":

All Hail! thou noble land!

Our fathers' native soil!

and further:

While the manners, while the arts

That mold a nation's soul

Still cling around our hearts,

Between let Ocean roll.

Our joint communion breaking with the sun;

Yet still from either beach

The voice of blood shall reach,

More audible than speech,

"We are One!"18

In this spirit there is reproduced the speech of Balfour, July, $191 \%$, on "Our Mutual Interests," in which he pointed with a special satisfaction to the progress of the United States because

${ }^{17}$ Ibid.

${ }^{18}$ Baldwin, The Story of Liberty, p. 204. 
"the thirteen colonies were British colonies"; because "the thirteen colonies, in spite of small controversies, grew up, broadly speaking, under the protection of England"; because

the men who founded the great American republic, the men whose genius contrived its Constitution, their forefathers who, struggling in the wilderness, gradually developed the basis of all that has happened since, were men speaking the English language, obeying and believing in English laws, and nourished upon English literature.

And then he concludes that the World War had bound together forever "the two great branches of the English-speaking race" for "one common purpose in one common understanding.".19

Regardless, however, of the spirit of comradeship of the World War, there still appears in the readers much anti-British literature of the Revolutionary War period. There frequently are found such stories as "The Boy, the Bees and the British," in which is told the episode of British soldiers robbing a Virginia home of food and horses, and how the wit of a little boy, by setting loose the bees upon the "Red Coats" as they were trying to take "Old Bay," a horse, saved the day. Then the boy ran and brought American soldiers. "So it was that the brave young American boy found a way to help his country, even though he could not join Washington's army. For the four hundred British soldiers were captured, and it was Jack with his angry bees who brought it about."20

There are many other stories of like sentiment, such as "How Andy Helped To Capture the Redcoats," a story of the capture of a small British force by a frontiersman and Andy ;" "Betty's Ride," the story of a little Quakeress, left alone at home near a besieged church, and how she carried a message to Washington although pursued by the British ;" the story of "Jabez Rockwell's Powder Horn" ;3 and the story of "A Patriot of Georgia," in which is narrated the incidents surrounding a legendary char-

${ }^{10}$ Ibid., pp. 224-26.

${ }^{20}$ Elson Readers Book Three, pp. 163-68.

"1 Natural Method Readers Third Reader, pp. 257-66.

${ }^{22}$ Child Library Readers Book Five, pp. 177-84.

${ }^{23}$ Natural Method Readers Third Reader, pp. 3-19. 
acter, Robert Sallette, who pursued the British with "ferocity.",24 Others might be named, but these will serve to illustrate.

Besides stories glorifying the achievements of mythical characters, there are those found both in prose and poetry and based upon truth, such as "A Tea Party," the story of the Boston Tea Party ;" "A Tea Party," the story of Edenton, North Carolina, women refusing to drink tea because it was taxed $;^{26}$ and "At Valley Forge," a narrative of the trials of the winter at Valley Forge. ${ }^{27}$ A popular story is that of "A Visit to General Marion's Headquarters," in which is told the story of a British officer visiting Marion, encamped north of Charleston, to see about the exchange of prisoners. Here the British officer saw American soldiers dressed in cast-off or captured uniforms of the British fighting forces. Marion himself was dressed in homespun and had only sweet potatoes for dinner. The British officer learned that the Americans were getting no pay except that of fighting for liberty. He was so impressed that he could fight no more and returned to England..$^{28}$

Excerpts from speeches, journals, diaries, reminiscences, and similar material appear, such as "Patrick Henry's Speech" of the phrase "Give me liberty or give me death" ;9 "Lexington and Concord," from William Emerson's Journal;" "A Famous Protest against the American War," by William Pitt " "Burke Ad-

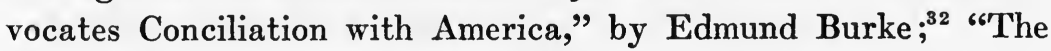

${ }^{24}$ Hartwell, Story Hour Readings Seventh Year, pp. 85-87.

${ }^{25}$ Hartwell, Story Hour Readings Sixth Year, pp. 158-60.

${ }^{26}$ Lincoln Readers Fourth Reader, pp. 117-19.

${ }^{27}$ Hartwell, Story Hour Readings Sixth Year, pp. 383-84.

${ }^{28}$ Heart of America Readers Fourth Reader, pp. 93-95. See also Horace Mann Readers Fifth Reader, pp. 131-35.

${ }^{29}$ Hartwell, Story Hour Readings Seventh Year, pp. 343-46. See also Baker and Thorndike, Everyday Classics Seventh Reader, pp. 150-53. Heath Sixth Readers, pp. 212-15; Haliburton Readers Fifth Reader, pp. 217-21; Horace Mann Eighth Reader, pp. 111-12; Elson Readers Book Seven, pp. 275-78.

${ }^{30}$ Ibid., pp. 304-6.

${ }^{31}$ Horace Mann Sixth Reader, p. 277.

${ }^{32}$ Ibid., pp. 276-77. See also Baker and Thorndike, Everyday Classics Seventh Reader, pp. 154-59. 


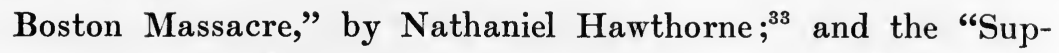
posed Speech of John Adams on the Declaration of Independence," by Daniel Webster. ${ }^{34}$

"Concord Hymn," by Ralph Waldo Emerson, appears in readers the most frequently of any of the poems of this epoch. ${ }^{35}$ Other popular selections are "General Joseph Warren's Address," by John Pierpont, "Paul Revere's Ride," by Longfellow, ${ }^{37}$ "The Minute Men of '76," by George William Curtis. ${ }^{38}$ "The Marching Song of Stark's Men," by Edward Everett Hale, ${ }^{39}$ "Song of Marion's Men," by William Cullen Bryant," and "Independence Bell." 41

Many other illustrations of the preservation of the literature of this period might be given. All tend to fire the imagination and to kindle sympathy for the colonies. Direct and intimate messages to the pupil from heroic characters are found in passages such as "The Capture of Ticonderoga," by Ethan Allen. Here Allen uses, with persuasiveness, descriptive adjectives and

${ }^{33}$ Horace Mann Eighth Reader, pp. 104-9.

${ }^{34}$ Baker and Thorndike, Everyday Classics Sixth Reader, pp. 264-67. See also Heath Sixth Reader, pp. 243-46.

${ }^{35}$ Horace Mann. Fifth Reader, pp. 393-94; The Natural Method Readers Fifth Reader, p. 339; Baker and Thorndike, Everyday Classics Sixth Reader, p. 262; Hartwell, Story Hour Readings Sixth Year, p. 385; Heath Sixth Reader, p. 311; Gordon, Fifth Reader, p. 203; Haliburton Readers Fifth Reader, p. 226.

${ }^{36}$ Elson Readers Book Seven, p. 274; Horace Mann Sixth Reader, pp. 287-88; Hartwell, Story Hour Readings Seventh Year, p. 335.

${ }^{37}$ Horace Mann Sixth Reader, pp. 278-83; Baldwin, op. cit., pp. 118-23; Hartwell, Story Hour Readers Fourth Year, pp. 168-73; Merrill Readers Fifth Reader, pp. 148-53.

${ }^{38}$ Horace Mann Sixth Reader, pp. 284-87; Haliburton Fifth Reader, pp. 221-25.

${ }^{39}$ Heart of America Readers Fourth Reader, p. 80.

${ }^{40}$ Horace Mann Fifth Reader, pp. 135-37; Baker and Thorndike, Everyday Classics Fifth Reader, pp. 190-92; Gordon, Fifth Reader, pp. 230-32; Haliburton Fourth Reader; Hartwell, Story Hour Readings Fourth Year, pp. 174-96; Elson Readers Book Seven, pp. 285-87.

${ }^{41}$ Merrill Readers Fifth Reader, pp. 204-6; Hartwell, Story Hour Readings, Fifth Year, pp. 381-84; The Nere Barnes Readers Book Four, pp. 233-38. 
dynamic verbs in a sentence such as the following: "The first systematic and bloody attempt at Lexington to enslave America thoroughly electrified my mind and fully determined me to take part with my country." 42 Selections in which Anglo-American relations are detailed from the writings of Washington Irving, Nathaniel Hawthorne, Jared Sparks, Thomas Paine, and George Bancroft proceed in similar channel. ${ }^{43}$

Stories of heroic character found in the readers attest to the popularity of the heroes of the Revolution and the preceding period: Nathan Hale, who mourned that he could lose but one life for liberty $;^{44}$ Molly Pitcher and her bravery $;^{45}$ John Paul Jones ;6 Robert Morris, "a great citizen" of America ;7 and Washington, about whom are many stories of his childhood to his later manhood. ${ }^{48}$

Thomas Jefferson, ${ }^{49}$ John Smith, ${ }^{50}$ and William Penn ${ }^{51}$ receive a share of the plaudits. The Pilgrims are also immortalized,

${ }^{42}$ Horace Mann Seventh Reader, pp. 74-77.

${ }^{43}$ Baker and Thorndike, Everyday Classics Seventh Reader, pp. 137-49; Horace Mann Seventh Reader, pp. 2-3; Horace Mann Eighth Reader, pp. 243-50, 136-43; Heart of America Readers, pp. 109-13; Elson Readers Book Seven, pp. 288-89; Heath Readers Fifth Reader, pp. 75-79.

${ }^{44}$ Horace Mann Eighth Reader, pp. 115-17.

${ }^{45}$ Hartwell, Story Hour Readings Seventh Year, pp. 57-59; Lincoln Readers Fourth Reader, pp. 258-62.

${ }^{46}$ Horace Mann Readers Sixth Reader, pp. 354-75.

${ }^{47}$ Hartwell, Story Hour Readings Sixth Year, pp. 379-82.

${ }^{48}$ Lewis and Rowland, The Silent Readers Fifth Reader, pp. 72-74; Nere Education Readers Book Two, p. 131; Hartwell, Story Hour Readings Sixth Year, pp. 201-2, Fifth Year, pp. 326-31, Fourth Year, pp. 162-67, Seventh Year, pp. 161-67, Eighth Year, pp. 302-3; Searson and Martin, Studies in Reading First Grade, p. 63; Baker and Thorndike, Everyday Classics Sixth Reader, pp. 258-60, 251-56, Third Reader, pp. 245-46; Natural Method Readers Third Reader, pp. 204-5; Horace Mann Sixth Reader, pp. 333-41, Fifth Reader, pp. 382-86, Eighth Reader, pp. 250-52, 131-33; Haliburton Readers Fifth Reader, pp. 227-32; Elson Readers Book Five, pp. 110-12; Monroe and Miller, The American Spirit a Basis for World Democracy, pp. 33-43.

\footnotetext{
${ }^{40}$ Heath Reader Fifth Reader, pp. 121-26.

${ }^{50}$ Lewis and Rowland, The Silent Readers Seventh Reader, pp. 238-43.

${ }^{12}$ Lewis and Rowland, The Silent Readers Fifth Reader, pp. 170-86.
} 
particularly by a poem like Felicia Hemans' "The Landing of the Pilgrims." 52 In many cases there is a carrying-over of hostility to England provoked by a recital of so-called oppression and restrictive acts of the mother-country.

${ }^{52}$ Hartwell, Story Hour Readings Sixth Year, pp. 377-78; Baldwin, The Story of Liberty, pp. 74-75. See also for other things: Nicholson, Heart of America Readers Fifth Reader, p. 12; Lincoln Third Reader, pp. 56-60; Hartwell, Story Hour Readings Eighth Year, pp. 293-94; Heath Reader Sixth Reader, pp. 84-85; Pratt, Stories of Colonial Children, pp. 9-10. 


\section{CHAPTER XX}

\section{THE AMERICAN AND HIS COUNTRY}

Many of the readers which contain literature of a historical and patriotic character are eminently successful in having collected selections of strong emotional appeal. They are charged with realism and with those qualities which vividly stir the imagination. Of all the books examined in this study none are more filled with powerful emotional passages than are the readers. Perhaps this is due to the great number of excerpts from orations delivered at times of national stress, perhaps to the great number of poems of heroic struggle and sacrifice, and perhaps to the able manner of presentation in the fictitious episodes intended to kindle and inflame the imagination of the one reading.

Much space is devoted to the flag, including the story of its origin, its symbolism, and the achievements of the country it represents. "The flag" has a place in even the first reader designed for the most elementary grade. It is also found in those books to be used in the upper grades. Of the well-known poems about the flag there appear most frequently "Your Flag and My Flag," by Wilbur D. Nesbit," "The American Flag," by J. R. Drake," "The Flag Goes By," by Henry Holcomb Bennett," "Union and Liberty," by Oliver Wendell Holmes," and "The

${ }^{1}$ The Nere Barnes Readers Book Three, pp. 30-31; Horace Mann Fourth Reader, p. 158; Natural Method Readers Third Reader, pp. 267-68.

${ }^{2}$ Horace Mann Seventh Reader, pp. 306-8; Baker and Thorndike, Everyday Classics Seventh Reader, pp. 371-73; Baldwin, The Story of Liberty, p. 147; Merrill Readers Fifth Reader, p. 109; Lyman and Hill, Literature and Living, Book Three, p. 389.

${ }^{3}$ Smith, The Easy Road to Reading Third Reader, pp. 310-11; Natural Method Readers Third Reader, pp. 1-2; Elson Readers Book Troo, p. 153, Book Seven, pp. 462-63.

${ }^{4}$ Heath Sixth Reader, pp. 43-44. 
Flag," by Arthur Macy. ${ }^{5}$ The sentiment in all is much the same as the following:

$$
\text { FLAG } 0^{\prime} \text { MY LAND }
$$

Up to the breeze of the morning I fling you, Blending your folds with the dawn in the sky, There let the people behold you, and bring you Love and devotion that never shall die. Proudly, agaze at your glory, I stand, Flag o' my land! Flag o' my land!

Standard most glorious, banner of beauty, Whither you beckon me there will I go, Only to you, after God, is my duty; Unto no other allegiance I owe.

Heart of me, soul of me, yours to command, Flag o' my land! Flag o' my land!

Pine to palmetto and ocean to ocean, Though of strange nations we get our increase, Here are your worshipers one in devotion. Whether the bugles blow battle or peace, Take us and make us your patriot band, Flag o' my land! Flag o' my land!

$$
\text { -T. A. } \text { DALY }^{6}
$$

Typical of prose selection is Franklin K. Lane's "The Makers of the Flag," which appears in several of the upper elementary grade readers. ${ }^{7}$ Many of the poems and pieces and prose seek to bring out what Henry Ward Beecher has said:

A thoughtful mind, when it sees a nation's flag, sees not the flag only, but the nation itself; and whatever may be its symbols, its

${ }^{5}$ Heart of America Readers, pp. 269-70; Lyman and Hill, Literature and Living, Book Three, p. 383; Horace Mann Readers Introductory Fourth Reader, p. 157.

' Hartwell, Story Hour Readings Sixth Year, p. 212.

'Elson Readers Book Seven, pp. 441-43; Nicholson, Heart of America Readers Fifth Reader, pp. 4-7; Hartwell, Story Hour Readings Fifth Year, pp. 394-97; Lewis and Rowland, The Silent Readers Eighth Reader, pp. 219-21; Lyman and Hill, Literature and Living, Book Three, pp. 387-89. 
insignia, he reads chiefly in the flag the government, the principles, the truths, the history, which belong to the nation which sets it forth. ....

This nation has a banner, too; and wherever it streamed abroad, men saw daybreak bursting on their eyes, for the American flag has been the symbol of liberty and men rejoiced in it. Not another flag on the globe has such an errand, or went forth upon the seas, carrying everywhere, the world around, such hope for the captive, and such glorious tidings.....

Let us then twine each thread of the glorious tissue of our country's flag about our heartstrings; and looking upon our homes and catching the spirit that breathes upon us from the battlefields of our fathers, let us resolve, come weal or woe, we will, in life and in death, now and forever, stand by the Stars and Stripes. ${ }^{8}$

The flag is closely associated in song and story with the achievements and sorrows of the battlefield. "Flag of the heroes who left us their glory," sings Holmes;" and "Washed in the blood of the brave and the blooming" $;^{10}$

Sing of the banner that aye shall be

Symbol of honor and victory!

Don't you thrill when the marching feet

Of jubilant soldiers shake the street,

And the bugles shrill, and the trumpets call.

And the red, white, and blue is over us all !11

Not only is the flag associated with the "glories" of the battlefield, but it is held to represent "the home of the free and the

${ }^{8}$ Heath Fifth Reader, pp. 348-51; Horace Mann Eighth Reader, pp. 133-36; Elson Readers Book Seven, pp. 460-61; "The American Flag," by Henry Ward Beecher.

"Union and Liberty;" Horace Mann Seventh Reader, pp. 226-27; also in Fifth Reader, pp. 377-78.

${ }^{10}$ Ibid., pp. 197-98, "God Save the Flag," by Oliver Wendell Holmes.

${ }^{11}$ Heart of America Readers Third Reader, pp. 242-43, "A Song of Our Flag," by Margaret E. Sangster. Many similar quotations might be given. 
land of the brave,"12 a land "always standing for the right" $;^{13}$ a land "that will not let anyone be oppressed,"14 "a sign of brotherhood and good will to all nations."15

The flag, then, is said to be expressive of that citizenship toward which the pupil is admonished to strive, and of the Americanism which is believed desirable in all peoples under American protection. To that end creeds and pledges of allegiance are proposed for memorization. Of these there are the well-known "American's Creed," "The Pledge to the Flag," and the "Pledge of the Athenian Youths." In addition there are many of the type reproduced here, under such a caption as the following, "Civic Creed for the Boys and Girls of the Great Republic":

God has made one blood all nations of men, and we are his children, brothers and sisters all. We are citizens of these United States and we believe our Flag stands for self-sacrifice for the good of all the people. We want, therefore, to be true citizens of our great country and will show our love for her by our works. Our country does not ask us to die for her welfare only-she asks us to live for her, and so to live and so to act that her government may be pure, her officers honest, and every corner of her territory a place fit to grow the best men and women, who shall rule over her. ${ }^{16}$

There is also similar sentiment voiced in "A Creed of Americanism," by William H. Keller :

There are many reasons why I should be proud of my native land and loyal to it and its institutions.

My native land, the United States of America, was the first to

${ }^{12}$ Searson and Martin, Studies in Reading First Grade, p. 14, Third Grade, p. 118; "The Star Spangled Banner" and "America," among other patriotic poems set to music, appear frequently. See Hartwell, Story Hour Readings Fifth Year, pp. 397-98; Horace Mann Fifth Reader, pp. 381-82; Haliburton Fifth Reader, pp. 195-97; Elson Readers Book Five, pp. 104-5; Elson Readers Book Two, pp. 152-53; Hartwell, Story Hour Readings Fourth Year, pp. 182-83; Baker and Thorndike, Everyday Classics Third Reader, pp. 247-48; Gordon, Second Reader, p. 88; Nere Education Readers Book Troo, p. 135.

${ }^{13}$ Gordon, Second Reader, p. 74.

${ }^{14}$ Haliburton Fifth Reader, pp. 198-202, "The Meaning of the Flag," by Charles F. Dole.

${ }^{15}$ Ibid. $\quad{ }^{16}$ Heart of America Readers Third Reader, p. 24. 
declare that all men have inalienable rights to life, liberty, and the pursuit of happiness.

Carrying out this declaration, the United States has a form in which we all are equal before the law. There is no position in the government to which any of us may not attain. Poor boys have attained the presidency of the United States, a greater honor than the throne held by any European monarch.

By the union of states our government gives each of us a greater range of civilized country to travel in than any other nation in history. ....

My country gives me the right to think, speak, and write my thoughts, and try to persuade my fellow citizens to think as I do provided that $I$ do not incite them to violent action and do not interfere with the liberty of any other citizen.

My country permits me to worship God according to the dictates of my conscience, and permits no union of church and government nor any favors to any form of religious belief.

My country with its public schools enables me to learn the thoughts and understand the achievements of the great and wise men of all the ages. The public school places the poor boy on a level with the rich boy and enables the attentive and studious boy to win the honors, regardless of the wealth of his parents. ....

My country has become a beacon light to all the other peoples of the earth, summoning them to leave the darkness of ignorance and dwell in the glorious light of liberty.

So again I pledge allegiance to you, the flag of my native land, beautiful banner of the brave and the free, and I thank God, who gave me life, that $\mathrm{I}$ am able to say, $\mathrm{I}$ am an American. ${ }^{17}$

Obligations to the world at large are occasionally mentioned. Lyman and Hill, for example, have a section in Book III of Literature and Living on "Promoting World Fellowship." Here are given extracts from literature proposing and glorifying peace

${ }^{17}$ Hartwell, Story Hour Readings Sixth Year, pp. 392-93. Among others, pledges are found in Baker-Thorndike, Everyday Classics Second Reader, p. 188; Heart of America Readers Third Reader, p. 244; Lincoln Readers Sixth Reader, pp. 34-37; Merrill Readers Sixth Reader, p. 138; The Child's World Second Reader, p. 128; Lewis and Rowland, The Silent Readers Eighth Reader, p. 103. 
for the world. "The Fatherland," by James Russell Lowell, is one of the selections given, and the last stanza may serve to present the sentiment of these authors in the section devoted to the general subject of world-fellowship:

Where'er a single slave doth pine,

Where'er one man may help another,-

Thank God for such a birthright, brother-

That spot of earth is thine and mine!

There is the true man's birthplace grand,

His is the world-wide fatherland $!^{18}$

Although war is glorified to a greater degree than the achievements of peace in most of the readers, one, however, finds such selections as "Daily Service," by Susan Coolidge, in which the man of true and simple life is said to "serve his country best."19 "What Constitutes a State," by William Jones, ${ }^{20}$ "The Army of Peace" and "Who Patriots Are," by Charles F. Dole, "True Patriotism," by Benjamin Harrison, ${ }^{22}$ and "Your Best and Hardest Job," by Hildegarde Hawthorne. ${ }^{23}$

But patriotic service, as it has been said before, receives the most striking eulogy when it represents service on the battlefield. ${ }^{24}$ The "homeland," its glories and blessings, cannot be more stir-

${ }^{18}$ Lyman and Hill, Literature and Living, Book Three, p. 540.

${ }^{19}$ Hartwell, Story Hour Readings Sixth Year, pp. 390-91.

${ }^{20}$ Horace Mann Eighth Reader, p. 83.

${ }^{21}$ Gordon, Fifth Reader, pp. 192-93; Heath Readers Fourth Reader, pp. 192-97.

${ }^{22}$ Hartwell, Story Hour Readings Seventh Year, pp. 350-51.

${ }^{23}$ Child Library Readers Book Five, pp. 169-75.

${ }^{24}$ Hartwell, Story Hour Readings Seventh Year, pp. 329-30; Heart of America Readers Third Reader, pp. 325-30; Lewis and Rowland, The Silent Readers Eighth Reader, pp. 160, 208-11, 212-15, Seventh Reader, pp. 159-66, 78-82, 25-27; Baker and Thorndike, Everyday Classics Sixth Reader, p. 272; Elson Readers Book Three, pp. 169-70; Field First Reader, pp. 131-38; Baker and Thorndike, Everyday Classics Seventh Reader, pp. 364-67, Fifth Reader, p. 195; Searson and Martin, Studies in Reading Third Grade, p. 233; and many others. 
ringly real than in Hale's "The Man without a Country."25 On the whole, the following quotations may summarize the greater portion of content devoted to inculcating attitudes, national and international:

Let our object be our country, our whole country, and nothing but our country. And by the blessing of God, may that country itself become a vast and splendid monument, not of oppression and terror, but of wisdom, of peace, and of liberty, upon which the world may gaze with admiration forever. ${ }^{26}$

We stand the latest, and if we fail, probably the last experiment of self-government by the people. We have begun it under circumstances of the most auspicious nature. We are in the vigor of youth. Our growth has never been checked by the oppressions of tyranny. Our constitutions have never been enfeebled by the vices and luxuries of the Old World.

Such as we are, we have been from the beginning simple, hardy, intelligent, accustomed to self-government and self-respect. The Atlantic rolls between us and any formidable foe. Within our own territory, stretching through many degrees of latitude and longitude, we have the choice of many products and many means of independence.

The government is mild. The press is free. Religion is free. Knowledge reaches or may reach every home. . . . ${ }^{27}$

All of us belong, to the same great country-the United States of America. It is the country of Washington and Lincoln. We believe it is the best country in the world. It is our duty as its citizens to love it, defend it, and to make it better in every way we can. ${ }^{28}$

And

We must have in this country only one flag-the American flag; and but one loyalty-that to the United States. ${ }^{29}$

${ }^{25}$ Lyman and Hill, Literature and Living, Book Three, pp. 358-74; Horace Mann Eighth Reader, pp. 269-301.

${ }^{26}$ From Daniel Webster, Horace Mann Sixth Reader, p. 343.

${ }^{27}$ Hartwell, Story Hour Readings Eighth Year, pp. 304-6.

${ }^{28}$ Hartwell, Story Hour Readings Fourth Year, p. 147.

${ }^{29}$ Baldwin, op. cit., frontispiece quoted from Theodore Roosevelt. 



\section{PART V}

TEXTBOOKS IN MUSIC AND FOREIGN LANGUAGE 



\section{CHAPTER XXI}

\section{MUSIC}

It has been said that music is the one universal language; assuredly there is no bond among peoples whose strength is greater or whose appeal stronger. To speak of its potency in

ELEMENTARY SCHOOL MUSIC BOOKS

\begin{tabular}{|c|c|c|c|}
\hline Title & Collection or Series & $\underset{\text { Book }}{\text { No. Songs in }}$ & $\begin{array}{c}\text { Pèrcentage of } \\
\text { Songs of } \\
\text { National and } \\
\text { International } \\
\text { Character }\end{array}$ \\
\hline Music Primer. & Eleanor Smith & 152 & 3.8 \\
\hline Book I....... & Eleanor Smith & 145 & 2.7 \\
\hline Book II. . & Eleanor Smith & 210 & 3.8 \\
\hline Book III. & Eleanor Smith & 206 & 6.7 \\
\hline Book IV . . . . . . . . & Eleanor Smith & 159 & 14 \\
\hline Songs of Childhood... & Music Education Series & 130 & 4 \\
\hline Introductory Music. . . . . . & Music Education Series & 182 & 4 \\
\hline Juvenile Music.......... . & Music Education Series & 158 & 6.9 \\
\hline Elementary Music.......... & Music Education Series & 209 & 9 \\
\hline Intermediate Music $\ldots \ldots \ldots$ & Music Education Series & 208 & 12.9 \\
\hline Three Part Music . . . . . . . . & Music Education Series & 153 & 10 \\
\hline Junior Music . . . . . . . . & Music Education Series & 164 & 12.8 \\
\hline First Year Music..... & Hollis Dann Music Course & 166 & 3 \\
\hline Second Year Music........ & Hollis Dann Music Course & 71 & 5.6 \\
\hline Third Year Music..... & Hollis Dann Music Course & 108 & 4.5 \\
\hline Fourth Year Music......... & Hollis Dann Music Course & 154 & 9 \\
\hline Fifth Year Music..... & Hollis Dann Music Course & 156 & 3.8 \\
\hline Sixth Year Music. . . . . & Hollis Dann Music Course & 159 & 7 \\
\hline Junior Songs. . . . . . . . . & Hollis Dann Music Course & 138 & 21 \\
\hline First Book of Songs........ & Foresman & 98 & 9 \\
\hline Second Book of Songs...... & Foresman & 111 & 9 \\
\hline Third Book of Songs...... & Foresman & 127 & 11 \\
\hline Fourth Book of Songs..... & Foresman & 125 & $\mathbf{9}$ \\
\hline Fifth Book of Songs... & Foresman & 172 & 11 \\
\hline Book I. . . . . . . . . . . & Progressive Music Series & 192 & 4 \\
\hline Book II. . & Progressive Music Series & 243 & 5 \\
\hline Book III. & Progressive Music Series & 207 & 4 \\
\hline Book IV. . . . . . . . . . . & Progressive Music Series & 151 & 10 \\
\hline Lyric Music Primer... & Johnston and Loomis & 106 & 4 \\
\hline Lyric First Reader. . . . . . . . & Johnston and Loomis & 198 & 8 \\
\hline Lyric Second Reader. . & Johnston and Loomis & 208 & 7 \\
\hline Lyric Third Reader... & Johnston and Loomis & 231 & 13 \\
\hline Primer............ & Universal School Music Series & 102 & 2 \\
\hline Book II. . & Universal School Music Series & 266 & 3 \\
\hline Book III... & Universal School Music Series & 224 & $\mathbf{5}$ \\
\hline Book IV...... & Universal School Music Series & 154 & 15 \\
\hline
\end{tabular}


rousing the emotions is a commonplace. One does not need to think far back in his own experience to envisage the effect of flying banners and soldiers marching to fife and drum. Nor is it difficult to recall the quickening of the pulse at the singing of patriotic hymns.

In the phase of this study devoted to an analysis of books in music commonly found in the schools, fifty books were examined, ranging from the elementary grades through the senior high

INTERMEDIATE GRADES, JUNIOR AND SENIOR

HIGH SCHOOL

\begin{tabular}{|c|c|c|c|}
\hline Title & Collector & $\underset{\text { Book }}{\text { No. Songs in }}$ & $\begin{array}{l}\text { Percentage of } \\
\text { Songs of } \\
\text { National and } \\
\text { International } \\
\text { Character }\end{array}$ \\
\hline Grammar School Songs. & Farnsworth & 84 & 4.7 \\
\hline The Laurel Unison Book.... & Armitage & 165 & 20 \\
\hline Junior Laurel Songs. . . . . . . . & Armitage & 267 & 10 \\
\hline Senior Laurel Songs. . . . . . & Armitage & 357 & 8.6 \\
\hline The Lake High School Song & & & \\
\hline Book. . . . . . . . . . . . . . & White & 178 & 8 \\
\hline Songs We Like To Sing..... & Alexander & 110 & 12 \\
\hline The American Song Book... & Levermore & 122 & 25 \\
\hline Twice 55 Community Songs & & & \\
\hline No. 1: The Brown Book.. & Birchard (publisher) & 120 & 15 \\
\hline Twice 55 Community Songs & Birchard (nublisher) & 138 & 03 \\
\hline Glee and Chorus Book...... & NeCollins & $\begin{array}{l}100 \\
110\end{array}$ & 12.7 \\
\hline Art Songs for High School... & Earhart & 160 & 6.8 \\
\hline The Junior Song and Chorus & & & \\
\hline Book. . . . . . . . . . & Giddings and Newton & 116 & 12 \\
\hline The School Song Book. . & McConathy & 197 & 15 \\
\hline
\end{tabular}

school. The statement in the accompanying tables summarizes the proportion devoted to songs carrying national and international points of view.

"America" appears in all the books examined; "The Star Spangled Banner" is found in nearly four-fifths (35 books) ; "Columbia, the Gem of the Ocean" in two-fifths (20); "America the Beautiful" in three-tenths (15) ; "Battle Hymn of the Republic" in approximately one-fifth (11); "Hail Columbia" in approximately one-sixth (8); and "Yankee Doodle" in about one-tenth (6). "Speed Our Republic," "The Battle Cry of Freedom," "America for Me," "America," by Sidney Lanier, and the "New 
American Hymn," by Soule, are among other patriotic songs appearing less than five times.

In many of the songs the same concepts gleaned from a study of textbooks in academic fields may be gained. America, in song, is a land of freedom as in "Our Native Song"; a land also of plenty and peace as well as freedom in such a song as "My Country," found in the Smith Fourth Book. "Liberty" and "freedom," for which our "forefathers fought and died," especially lend themselves to poetic fancy. Because of the blessings thus bestowed the music books admonish a loyalty to country which expresses itself in service in time of war. ${ }^{2}$

With the earliest primer the qualities needed for a good soldier and the glory of service to country are emphasized. In this connection it may be well to quote from "The Sergeant" intended for singing in the fourth to sixth grades, and typical of many songs found:

Come, noble lads, enlist with me And life in earnest you shall see, I'll lead you on to fame.

Why waste your life in ploughing fields?

Content if you can earn your needs, Why be so poor and tame?

Now hear the rolling drums resound, Come leave your fields for nobler ground, And win a soldier's name.

Another song of the same grade level is "Happy Is Our Soldier Band":

Happy is our soldier band, Happy is our soldier band, Laughing still at care or sorrow, Much today and naught tomorrow,

${ }^{1}$ Eleanor Smith, Music Course, Book Four, p. 210.

${ }^{2}$ For example, "America to Her Children," in Eleanor Smith's Music Course, Book Three, p. 5. Also in "Fatherland's Psalm." 
Now on sea and now on land

Shrill and clear the fifes and trumpets sound,

Loudly clash the guns and cannons,

At the noise, exulting our bosoms bound,

Death or glory all demand,

Happy is our soldier band,

Happy is our soldier band. ${ }^{3}$

In Book One of the Eleanor Smith Music Course, the pupil gains this impression:

Soldier lad, brave and glad,

Eyes a beaming, Colors gleaming,

Marching so, See him go

To fight his country's foe. ${ }^{4}$

Similar sentiment is expressed in Songs of Childhood:

"Soldier boy, soldier boy,

Where are you going,

Waving so proudly the red, white and blue?"

"I'm going to my country

When duty is calling;

If you'll be a soldier boy,

You may come, too."5

War is thus extolled in song and story. All of the books examined have songs of this character. It would be needless repetition to enumerate the many songs having the theme "Playing Soldier," "The Parade," "The Soldier Song," and so forth. ${ }^{6}$ On the other hand, although in the minority, some songs praising peace are to be found. Such is that of "World Peace," by George

${ }^{3}$ Eleanor Smith, Music Course, Book Four, pp. 32, 236.

${ }^{4}$ Eleanor Smith, Music Course, Book One, p. 32.

${ }^{5}$ Songs of Childhood, p. 140.

"Others are "War Song of the Hussites," "Weave in, My Hardy Life" by Whitman, "When Johnny Comes Marching Home," "The Two Grenadiers," "Tramp, Tramp, Tramp," "Soldiers' Chorus" from Faust, "Sleep, Noble Hearts" by Frederic Manley, "Roman War Hymn" from Rienzi, "The Red Scarf" by Southey, "Our Patriot Fathers" from Iolanthe, "Men of Harlech," "Marching Song," "March of Triumph," "Let Me Like a Soldier Fall." 
Huntington, "The Spirit of Peace," by M. A. L. Lane, "Let Peace Endure," by Katherine Whitmore, "Let Dread War Cease," "Hear O Ye Nations!" by Frederick L. Hosmer, and the "Anvil Chorus," from Il Trovatore.

Patriotism and love of country, as well as homage to the flag and what it signifies, are praised in song from the first-grade primer through the books intended for senior high school use. Allegiance is pledged to the flag, the pledge of allegiance commonly found in civics and history textbooks being set to music. Of the songs having a local color, "Dixie" and "Maryland, My Maryland" appear most frequently.

Some of the books contain the national anthems or patriotic airs of other countries. The "Marseillaise" appears the most often. Two books include "God Save the King" and "Rule Britannia." "The Watch on the Rhine" was found in four books, but they were published before the World War. Other national airs or songs containing material on other countries than America are "Swiss Battle Song," "In Sweden" by Lillian Vandevere, "Santa Lucia," "Polish National Song," "Dombrowski's Men," "Polish Fatherland Song," "Poland Fair," "Norwegian Sailor Song," "Sons of Dear Norway," "O Land of My Fathers" (Welsh national song), "Japanese National Anthem," "Italian National Anthem," "Italia," from Boccaccio, "Oh, Italia, Beloved," from Lucrezia Borgia, "King Christian" (Danish national song), "Come Back to Erin," "O, Canada," "Bohemia, My Fatherland," "Bohemian National Hymn," "Austrian National Hymn," and some Scotch songs. 


\section{CHAPTER XXII \\ TEXTBOOKS IN FOREIGN LANGUAGE}

\section{FRENCH}

France, in the textbooks of the French language for the children of our public schools, does not suffer in any degree, for she is described as a beautiful, free country, whose government is a republic with the motto "Liberty, Equality and Fraternity." Indeed, France is "queen of nations," a great country of brave soldiers and wise men. ${ }^{3}$

Service to country in time of war is given particular attention and high praise. ${ }^{4}$ Stories of a peasant's success in outwitting the enemy (the Germans) by hitching his oxen up wrong for their use, ${ }^{5}$ the surrender of the six burghers to England at Calais to save their country, ${ }^{6}$ and incidents in warfare detailing the bravery of children, as well as adults, are found in the pages of the books examined. ${ }^{7}$ There is much emphasis placed upon the love of the Frenchman for his country, and his willingness to sacrifice all, if need be, in its behalf. "Love of country is one of the great national virtues of this country," it is said; and the bravery of soldiers in their country's service is described in glowing terms. ${ }^{8}$

Joan of Arc, Charlemagne, and Napoleon are chief among the heroic figures discussed in the textbooks read. Bravery, self-

${ }^{1}$ Méras and Roth, Petits contes de France, p. 17; A. de Monvert, La Belle France, p. 11.

${ }^{2}$ Labiche and Martin, Le voyage de Monsieur Perrichon, pp. 75, 13.

${ }^{3}$ Lavisse, Histoire de France, p. 195.

${ }^{4}$ Ibid., pp. 157-58, 64-67; Méras and Roth, op. cit., p. 55.

- Méras and Roth, op. cit., p. 19.

'Lavisse, op. cit., pp. 64-67.

${ }^{7}$ Ibid., 67.

${ }^{8}$ A. de Monvert, op. cit., p. 34; Méras and Roth, op. cit., pp. 104-9; Lavisse, op. cit., p. 154 . 
sacrifice, and devotion to country are virtues said to be exemplified by them. ${ }^{9}$

Much attention in the readings is focused upon GermanFrench relations in which Alsace-Lorraine holds a conspicuous place. The love of these people for France, their hatred for Germany, and their ultimate deliverance are pictured in realistic language. ${ }^{10}$ In the Phonetic Edition of Chardenal's Complete French Course there are many examples of the unending animus said to have existed between these two countries.

In the Chardenal Phonetic Edition the frontispiece is the picture of the statue by Mercie of an Alsatian woman seizing the gun of a dying soldier, and symbolizing the defense of Belfort in the Franco-German War of 1870. It is called "Quand Mẽeme!" In the "Additional Selections for Reading" there is found much to inspire the reader with a hatred for Germany. The first reading, entitled "The Statue in Spite of Everything," describes the statue of Strassburg. It declares that before the World War no Frenchman was able to pass before this statue silent and veiled, without seeing there the symbol of faithfulness in captivity, without feeling a secret humiliation for the defeat of the country and a remorse at the apparent indifference of France toward the inhabitants of the annexed provinces-an indifference occasioned because France would not have taken the responsibility of horrid war in the hope of revenge. In silence and resignation, it is said, France awaited the awakening of justice. And it was Germany herself, the story goes on to say, who awakened it. It was Germany who broke the Treaty of Frankfort. It was Germany who let loose the war. Following the war, the statue was unveiled and covered with flowers and the tricolor, according to the narrative, for Alsace and Lorraine were French again. ${ }^{11}$

Another reading, "L'Alsace-Lorraine," carries the same general idea of Alsatian love for France and hatred for Germany.

'Méras and Roth, op. cit., pp. 109-13; Lavisse, op. cit., pp. 17-20, 78-85, 165-66; Méras and Roth, op. cit., pp. 122-26; A. de Monvert; op. cit., p. 18, 76; Mairet, La Tâche du petit Pierre, p. 60; Merimée, Colomba, p. 9.

${ }^{10}$ Lavisse, op. cit., p. 175 ; Méras and Roth, op. cit., p. 56.

${ }^{11}$ Chardenal, Complete French Course, Phonetic Edition, p. 364. 
Because they were separated from the mother-country "by violence," they are said never to have ceased, with a tenacity which is the admiration of the world, to affirm their unshakable attachment, their unalterable loyalty to France. The author points out that the Germanization of a people so patriotic was difficult, if not impossible. According to the census of 1895, he says that 160,000 were said to speak French habitually. In 1900, five years later, 200,000, among whom were 52,000 children, spoke the language of France. The affection of Alsace and Lorraine for France is thus pictured as almost a religion. It became everywhere, the story declares, the mission of women to combat the influence of German culture in teaching French secretly to the children, and telling them the exploits of their ancestors in the service of France. Then came the day of deliverance in the World War, when, after forty-eight years, they were freed from German rule. It was the end of a "long nightmare," the "realization of a dream." The French uniform became the symbol of liberation, the author declares.

The reading further narrates events connected with the celebrations attending the evacuation of the Germans. It ends with the story of a little boy who, on the day of triumphal entry of the French soldiers, ran to the cemetery and stopping before the tomb of his grandfather, on which he placed a little tricolor, cried out, "Grand-père, il sont la !"12

These extracts are typical of the discussions attending FrancoGerman relations in $\mathbf{1 8 \% 0}$. From the French books the reader inevitably conceives a dislike for the conqueror and a sympathy for the conquered.

\section{SPANISH}

To the Spaniards is attributed, in the textbooks of Spanish, the rare art of successful colonization. They are pictured as a hardy people, able to overcome difficult obstacles, who are brave, polite, and happy. ${ }^{13}$ In its past Spain is described as a great

${ }^{12}$ Ibid., pp. 373-77.

${ }^{13}$ Dorado, Primeras lecturas en Español, pp. 1, 48; Ibañez, Vistas Sudamericanas, p. 16. 
and powerful nation with immense colonies in the New World, ${ }^{14}$ to which it contributed as much as any nation of the time could have contributed. ${ }^{15}$

\section{ITALIAN}

As may be expected, readings in textbooks in Italian deal largely with Italian peoples and events. Among the former are Cavour, Mazzini, and Garibaldi, all extolled and honored. ${ }^{16}$ Some of the latter treat Italian efforts to gain freedom and unity, particularly from 1815 to 1870 .

In general, to Italy is ascribed, not only a "sunny climate," but a spirit of beauty reflecting itself in the works of man, ${ }^{17}$ yet today afflicted by great illiteracy and ignorance. ${ }^{18}$ To the Italian peasant are attributed gentleness and natural goodness, patience, industry, and frugality. ${ }^{19}$ Books point out that from the Italian have come the works of men like Petrarch and Boccaccio, the architecture, sculpture, painting, and music of Donatello, Verrochio, Michaelangelo, Leonard da Vinci, Raphael, Bellini, Palestrina, Rossini, Verdi, and others. ${ }^{20}$ In the realm of science the contributions of these people have been no less, it is held, than in other things.

In excerpts relating to foreign relations, Austria comes in for a fair share of attention. ${ }^{21}$. As in the French books, stories narrating heroic exploits in war find a conspicuous place. ${ }^{22}$ The American pupil reading these textbooks would conceive only respect and liking for the Italian. On the other hand, in the books read, there appeared far less of international animus in the narratives than in many other books analyzed.

${ }^{14}$ Dorado, op. cit., pp. 45-46.

${ }^{15}$ Nelson, Spanish American Reader, pp. 314-15; Ibañez, op. cit., p. 16.

${ }^{16}$ Van Horne, Il Resorimento.

${ }^{17}$ Wilkins and Marinoni, L'Italia, p. 6.

${ }^{18}$ Ibid., p. 23.

${ }^{19}$ Ibid., p. 30.

${ }^{20}$ Ibid., chaps. ix, x, xi.

${ }^{21}$ See, for example, De Amicis, Cuore, pp. 56-65.

${ }^{22}$ Ibid., pp. 12-14. 

PART VI

OFFICIAL POLICIES 



\section{CHAPTER XXIII}

\section{LAWS AFFECTING CIVIC INSTRUCTION}

As early as 1642 the American people evinced an interest in the schools through promulgations respecting the character of instruction-an interest which has persisted through legislation to the present. These declarations at all times have reflected the dominant interest of the period in which they were enacted, departing from the purely religious purpose of education held by the colonial fathers to that of the nationalism of the present day.

Following the entrance of the United States into the World War, legislators and others came to be peculiarly sensitive as to the character of American patriotism. During the war the apprehension that a disunited public opinion would prove the undoing of the allies in arms led to the passage of laws regarding the teaching of foreign languages in the public schools, the character of instruction in history, and the speech and loyalty of teachers. Since 1918 a wave of patriotic fervor has led to the passage of many laws tending to develop a loyalty to country through the required teaching of national history, the Constitution of the United States, special observance days, and patriotic exercises and legislation respecting the content of textbooks as well as oaths of loyalty required of teachers.

STATUTES RELATING TO THE SOCIAL STUDY CURRICULUM SINCE 1917

Beginning with 1917 there has been a steady increase in the number of laws passed to require the teaching of the social studies, particularly American history and the Constitution of the United States. Added to these requirements were frequently found provisions making state history and civics mandatory. Occasionally a statute prescribed courses in problems of democracy, as well as other offerings in social and political science. All were directed, however, toward promoting an understanding of 
American citizenship as commonly conceived, including instruction to develop "a love of country and a devotion to the principles of American government."1

By 1923 statutes of this nature were enacted by Arkansas, New Hampshire, Connecticut, Pennsylvania, Kentucky, Texas, Delaware, Alabama, Georgia, Tennessee, Texas, California, New York, Massachusetts, New Jersey, Ohio, Iowa, Kansas, Washington, Maine, Wisconsin, Michigan, Illinois, Nebraska, Oklahoma, Colorado, Utah, Arizona, Nevada, New Mexico, Virginia, and Idaho. ${ }^{2}$ From 1923 to 1927 sixteen states engaged in legislation

${ }^{1}$ See the law of Oklahoma, Acts of Oklahoma (1921), chap. 112, secs. 1, 2, 3, 4. For a more complete discussion of laws affecting the social study curriculum, see Pierce, Public Opinion and the Teaching of History, chaps. i-iv.

${ }^{2}$ General Lawes of Vermont (1917), chap. 60, sec. 1277, p. 301. Lazes of Montana (1917), chap. 128, par. 601, p. 309. Digest of the Statutes of Arkansas (1919), chap. 158, par. 9066, p. 547. Lares of New Hampshire (1921), chap. 85, sec. $10(3)$, p. 125. In 1919 history and civics were required. In 1918 Connecticut carried over a law from the Revision of 1902 prescribing United States history (General Statutes of Connecticut [1918], chap. 44, sec. 835, I, 308). Pennsylvania incorporated a law of 1911 prescribing instruction in general history and civil government in her Statute Law of 1920. Digest of the Statute Law of Pennsylvania (1920), par. 5102, p. 470. In Kentucky, United States history, state history, and civil government were required in 1918, carried over from a law of 1893 (Statutes of Kentucky [1918], art. III, par. 4383, III, 866; Lares [1916], chap. 24, art. III, sec. 24, p. 162). In Texas in the Compiled Statutes of 1920 was again included a law requiring the teaching of civil government and state and national history (Statutes of Texas [1920], art. 2783, p. 467). Laws of Delaware (1919), art. 2283, sec. 11, p. 356; also Laws, Special Session, 1920, Ninetyseventh Assembly, sec. 12, XXXI, 113. General Lares of Alabama (1919), art. 3, p. 571; Acts of Georgia (1919), sec. 18, p. 295. Compilation of the Statutes of Tennessee (1917), art. XV, sec. 1453, I, 983; ibid., 1454. Laws of South Dakota (1919), sec. 7511, p. 154. Lawes of California (1917). chap. 549, p. 728. Approved May 8, 191\%. It was the same for the social studies for the elementary schools in 1921 (Statutes [1921], chap. 486, p. 739). A law of Illinois in which instruction was to be devoted to "raising the standard of good citizenship" was passed in 1909, and was still on the statute books in 1917 (Revised Statutes [1917], p. 273). Laws of New York (1918), chap. 241, art. XXVI-C, secs. 705, 706, pp. 886-87. See the discussion under "Oaths of Allegiance as Teacher Requirements" for a statement regarding the repeal of the Lusk Law. General Acts of Massachusetts (1918), pp. 294-95; Acts (1920), chap. 411, p. 418. General Statutes of Connecticut (1918), chap. 45, sec. 852, I, 312. Acts of New Jersey (1919), 
pointed toward the social study curriculum, in order to instil "into the hearts of the various pupils . . . an understanding of the United States .... a love of country and . . . a devotion to the principles of the American government."3

chap. 125, p. 304. Lazes of Pennsylvania (1919), sec. 1607, pp. 544-45. In 1921 the law relating to courses of instruction for public and private elementary schools was amended but carried with it the requirement of United States history, history of Pennsylvania, and civics, including "loyalty to the state and national government" (Commonwealth of Pennsylvania, Department of Public Instruction, The School Lare . . . [1921], sec. 1607, p. 116). Laws of Ohio (1919), secs. 7645 and 7762, p. 542. Acts of Iowa (1919), chap. 406, p. 535. Private as well as public schools were included. Lares of Kansas (1919), chap. 257, secs. 2 and 3, p. 352; Session Lares of Washington (1919), p. 50. Alabama in 1919 added community civics to her elementary school curriculum but merely enumerated her subjects. General Lares of Alabama (1919), art. 3, sec. 7, p. 571. Resolves of Maine (1921), chap. 25, p. 27. Lares of New Hampshire (1921), chap. 85, sec. 5(3), p. 114. Acts of Michigan (1921), No. 209, secs. 1, 2. Wisconsin Session Lars (1921), chap. 81, p. 152. Lares of Illinois (1921), pp. 820-21. Acts of Iowa (1921), pp. 8182 ; Lares of Nebraska (1921), chap. 53, sec. 6924, p. 230. Acts of Oklahoma (1921), chap. 112, secs. 1, 2, 3, 4. In cases of a violation a fine of not less than $\$ 100$ and not more than $\$ 500$ or imprisonment in the county jail for not less than thirty days nor more than six months, or both, may be the penalty. A teacher is subject to discharge or removal in case of malfeasance, and a college (corporation) is liable to a revocation of its charter. Lares of Colorado (1921), chap. 216, p. 728. Acts of Arizona (1921), chap. 140, sec. 1, p. 312. Statutes of Nevada (1921), p. 28. Lares of New Mexico (1921), chap. 172, p. 364. Statutes of California (1921), chap. 486, p. 739. Acts of Virginia (1922), p. 69. Virginia School Lares (1923), p. 41; Public Lares of Rhode Island (1922), chap. 2195, sec. 17, Lares of Utah (1921), chap. 95, p. 284. Lares of Nevada (1917), chap. 146, p. 245. Compiled Statutes of Idaho (1919), p. 269, par. 944.

${ }^{3}$ The phraseology varies somewhat, but often many laws are much the same even as to language. Laws as passed during 1923-27 can be found in the statute books of the following states: Digest of School Lares . . . . of Arkansas .... (1923), p. 166. Approved March 23, 1923, this law provides that no person can graduate from high school without at least one full year's work in American history and civics; School Lazs of Mississippi (1924), chap. 283, p. 3; School Lares of Ohio (1923), p. 41; Public School Lares of Tennessee . . . (1923), p. 35; Acts of West Virginia (1923), chap. 10, sec. $9 a$, p. 40. Laws of Alabama (1923), p. 87; School Lares of the State of Idaho (1923), p. 57; Acts of New Jersey (1923), chap. 17, p. 17; Laws of Oregon (1923), chap. 7, sec. 102; Lares of Utah (1923), chap. 4; Lares of New York (1924), chap. 64, or article 26-d, sec. 797. School Lares of Delaware (1923), pp. 62-63. Georgia School Code.... (1923), p. 70. The 
Nearly all these enactments provide that instruction in the required subjects shall begin in the elementary grades, continue in the high school and in courses in state colleges, universities, and educational departments of state and municipal institutions to an extent to be determined by the superintendent of public instruction or by the state board of education. ${ }^{4}$

\section{LEGISLATION REGARDING SOCIAL STUDY TEXTBOOKS}

The most significant laws respecting textbooks since the World War deal with the character of the subject matter in histories as commonly written. They are the result of an apprehension arising from a misgiving that America is lacking in patriotisman apprehension noticeable in other legislation of this period.

In 1918, one of the Lusk Laws passed in New York prohibited the use of any textbook which contained statements seditious in character, disloyal to the United States, or favorable to the cause of any enemy country. The law created a commission composed of the commissioner of education and two persons designated by the regents of the University of the State of New York. To this body any person might present written complaints against textbooks in "civics, economics, English, history, language and literature," which were then to be examined "for the purpose of determining whether such textbooks contain any matter of statements of any kind which are seditious in character, disloyal to

Public School Law of North Carolina Codification (of 1923), p. 120. School Legislation of the Thirty-eighth Legislature [of Texas], pp. 36-37. Lares of Minnesota (1923), chap. 291, p. 388. Lares of New Mexico (1923), chap. 148, sec. 1417, p. 325; also Nere Mexico School Cods (1923), p. 34. Statutes of California (1923), chap. 176, secs. 1 and 2.

"The following provide that the course start not later than the eighth grade: Statutes of California (1923), chap. 176; Lares of Alabama (1923), p. 87; School Lares of Delareare (1923), pp. 62-63; School Lares of the State of Idaho (1923), p. 57; Lares of Minnesota (1923), chap. 291, p. 388; Oregon School Lares (1923), p. 39, Lares (1923), chap. 7, sec. 102; Public School Lares of Tennessee (1923), p. 35, Lares of Tennessee (1923), chap. 17, sec. 1, pp. 61-62. In New Jersey the seventh grade is prescribed for the beginning of the study, Acts of New Jersey (1923), chap. 17, p. 17. In Arkansas it is required that "such teaching shall commence in the lowest primary grade," but Arkansas history may be substituted for American history in one of the grades (Digest of School Laws of Arkansas, loc. cit.). 
the United States or favorable to the cause of any foreign country with which the United States is now at war."5 In case the commission disapproved of the book after examination, the law prescribed that the reasons be forwarded to all boards of education, who then must abandon the use of the book. It was further provided that any person in authority continuing to use a condemned book would be considered guilty of a misdemeanor.

Beginning with the year of 1922, concerted efforts were made by private organizations to control the content of history textbooks. In general, the criticisms against the histories in use were sponsored by patriotic and racial organizations seeking to rekindle the traditional treatment of relations with Great Britain, particularly during the American Revolution and the War of 1812.

One result of this agitation was the proposal of laws directed against the content of textbooks. In 1923 the commonwealth of Wisconsin proscribed by statute any textbook "which falsifies the facts regarding the war of independence, or the war of 1812, or which defames our nation's founders or misrepresents the ideals and causes for which they struggled and sacrificed, or which contains propaganda favorable to any foreign government."

Oregon passed a law of like character. In this state the use of any textbook has been prohibited which "speaks slightingly of the founders of the republic, or of the men who preserved the union, or which belittles or undervalues their work." Eff enact similar laws have been unsuccessful in the legislatures of New York and New Jersey. ${ }^{8}$

Against these attempts at censorship arose active protest from educators, historians, the press, and others. In New Jersey, the bill as introduced in the Assembly provoked opposition from

${ }^{5}$ Lares of New York (1918), par. 674, p. 892, approved April 17, 1918.

- Lares of Wisconsin (1923), chap. 21, secs. 40, 36.

${ }^{7}$ Oregon School Laws (1923), chap. iii, sec. 571, p. 169.

${ }^{8}$ State of New York, 3d Rdg. 652. Nos. 602, 1781, 1887. Int. 581. In Senate, February 7, 1928. Also No. 1186. Int. 1086. In Senate March 5, 1924. For New Jersey: Assembly, No. 14. Introduced January 8, 1924, by Mr. Williams. 
the faculty of Princeton University, who resolved that "such legislation is in direct contravention of the fundamental principles of freedom of speech and of the press, and calculated to impair the integrity of education in both the public and private institutions in the State of New Jersey."9 In December, 1923, the American Historical Association voiced a vigorous protest against an official censorship which would "inevitably bring about a ruinous deterioration both of textbooks and of teaching."10 In discussing the results of such a censorship the New York Times aptly expressed the sentiment of many when it declared that it was inconceivable that "any honest man would wish to write textbooks in history for children under such statutory prescription."

\section{LAWS ON TEACHING FOREIGN LANGUAGE AND THE}

USE OF ENGLISH

During the World War, the enthusiasm for a patriotism deemed unalloyed by the legislator led to the passage of laws pertaining to the teaching of foreign languages in the schools. German as a popular foreign-language study and as the language of one of the enemy powers came in for a large share of the lawmakers' attention. Whereas laws permitting the teaching of German had been passed by states such as Ohio and Indiana prior to 1917, following the World War there are found statutes prohibiting the teaching of this subject. For instance, Ohio declared, in a statute prior to the war,

The board of any district shall cause the German language to be taught in any school under its control, during any school year, when a demand therefor is made, in writing, by seventy-five freeholders resident of the district, representing not less than forty pupils who are entitled to attend such school, and who, in good faith, desire and intend to study the German and English language together; but such demand shall be made at a regular meeting of the board, and prior to the beginning of the school year, and any board may cause the

' Nere York Times, February 12, 1924.

${ }^{10}$ American Historical Reviere, XXIX (April, 1924), 428. A similar sentiment was expressed at the annual meeting of 1927.

${ }^{11}$ Nere York Times, April 19, 1923. 
German or other language to be taught in any school under its control without such demand. ${ }^{12}$

Following the war, the phase of the law dealing with this subject decreed that "the German language shall not be taught below the eighth grade in any of the elementary schools of this state."13

A law, passed in Louisiana in 1918 and repealed in 1921, prohibited, in like manner, the teaching of German in public or private elementary, high, or higher schools. ${ }^{14}$ In 1919, and 1921 New Hampshire permitted instruction in foreign languages in the curriculum of the public schools of that state, provided that such instruction did not abridge the teaching of required subjects. ${ }^{15}$

A law common to those states enacting restrictive legislation of this type is that which decrees that all instruction must be in English. Sometimes it is prescribed that an exception may be made in the case of the teaching of foreign languages. Statutes of this kind are found in the enactments of Alabama, Connecticut, Idaho, Maine, Nebraska, Nevada, New Hampshire, Oklahoma, and Pennsylvania. For example, the Nevada law sets forth:

It shall be unlawful for any board of school trustees, regents, or board of education, or for any teacher or other person teaching in the public or private schools of the State of Nevada, to cause to be taught or to teach any subject or subjects, other than foreign languages, in the public or private schools of the State of Nevada in any language except English.

Alabama requires that "English shall be the only language employed and taught in the first six grades of the elementary school," and Mississippi insists that "all textbooks adopted for use in the public schools of the state shall be printed in English

${ }^{12}$ General Code of Ohio (1910), sec. 7729, p. 1636. See also Burns's Annotated Indiana Statutes (1914), III, 384.

${ }^{13}$ General Code of Ohio (1920), sec. 7762-1, p. 3558. Burns' Annotated Indiana Statutes, Supplement (1921), V, sec. 6581a, 881.

${ }^{14}$ Acts of Louisiana (1918), p. 188; ibid. (1921), p. 102 (Special Session).

${ }^{15}$ Lares of New Hampshire (1919), chap. 106, sec. 13(3), p. 161; ibid., chap. 85 , sec. $10(3)$, p. 125 . 
except such books as shall be adopted as textbooks in the study of foreign language."16

In addition to the laws already noted, enactments that English shall be the medium of instruction in the schools are found on the statute books of Arkansas, Colorado, Delaware, Georgia, Illinois, Iowa, Kansas, Louisiana, Minnesota, New Jersey, New York, North Carolina, Ohio, Oregon, and West Virginia. ${ }^{17}$ To these states may be added Indiana, Michigan, Montana, North and South Dakota, Texas, and Washington, at some time advocates of this prescription. It is interesting to note that only Florida, Kentucky, Maryland, Massachusetts, Missouri, New Mexico, Vermont, Virginia, and Wyoming have not subscribed to such a prescription. ${ }^{18}$

In some states where a strong foreign element predominates,

${ }^{16}$ Statutes of Nevada (1919), chap. 133, p. 247; Supplement to Digest of Statute Law of Pennsylvania (1924), sec. 5089, p. 143; Compiled Statutes of Idaho (1919), sec. 985, p. 280; Lares of Maine (1921), chap. 25, p. 27; Compiled Statutes of Nebraska (1922), secs. 6457-62, p. 2045; Lares of New Hampshire (1921), chap. 85, sec. 13, p. 125; Public Acts of Connecticut (1923), chap. 166, p. 3591; General Acts of Alabama (1919), No. 442, art. 3, sec. 7, p. 571; Hemingway's Annotated Mississippi Code (1917), sec. 7838, II, 3127.

${ }^{17}$ Digest of Statutes of Arkansas (1919) sec. 9062, p. 2329; Compiled Lares of Colorado (1921), sec. 8497, p. 2179; Laws of Delaware (1921), chap. 160, sec. 8, p. 482; Supplement to Park's Annotated Code of Georgia (1923), sec. 1432A, III, 295; Cahill's Revised Statutes of Illinois (1923), sec. 401, p. 3148; Code of Iowa (1919), secs. 2363, 2364, p. 690; Revised Statutes of Kansas (1923), par. 72-1101, p. 1170; Constitution of Louisiana (1921), art. 12, sec. 12; Lares of Minnesota (1919), chap. 320, p. 337; Acts of Nere Jersey (1919), chap. 35, p. 71; Lares of New York (1921), chap. 386, sec. I, II, 1211; Public Lares of North Carolina (1923), chap. 136, sec. 39, p. 321; General Code of Ohio (1920), sec. 7762-1, p. 3558; Olson's Lares of Oregon (1920), sec. 2223-3, I, 1274; Barnes's Code of West Virginia (1923), chap. 45, sec. 9, p. 823.

${ }^{18}$ Burns' Annotated Statutes of Indiana, Supplement (1921), sec. 6581a, V, 881; Constitution of Michigan (1923), art. 11, sec. 9; Revised Code of Montana (1921), sec. 1054, I, 540; Compiled Lazes of North Dakota (1913), sec. 1199, I, 290; Revised Code of South Dakota (1919), sec. 7511, Vol. II, sec. 1878; Complete Statutes of Texas (1920), art. 2782, p. 467; Remington's Compiled Statutes of Washington (1922), sec. 4681, II, 698. 
the language of that nationality is permitted, as French in Louisiana and Spanish in New Mexico. ${ }^{19}$

\section{OATHS OF ALLEGIANCE AND CITIZENSHIP AS REQUIREMENTS}

FOR TEACHERS

Laws requiring American citizenship and oaths of allegiance for all who would teach in the public schools are also found among the statutes passed beginning and following the World War. In 1917 a provision of the Lusk Laws of New York forbade "the utterance of any treasonable or seditious act" by teachers or employees of the public schools. ${ }^{20}$ In 1918 and 1919 citizenship was made a qualification essential to teachers, and in 1921 loyalty and obedience to the government of the state were enjoined by statute upon all who would teach. ${ }^{21}$ Aggressive opposition to such control led to a repeal of the statutes by the state legislature in 1923, to which Governor Alfred E. Smith affixed his signature.

Laws similar to the statutes passed by New York are found in Ohio, Michigan, West Virginia, Tennessee, Oklahoma, Nebraska, South Dakota, Nevada, Idaho, Montana, and Washington. In 1919 Michigan, Nebraska, Tennessee, Montana, and Washington enacted statutes requiring that all teachers of the public schools must be citizens of the United States, and Idaho kept a law of 1897 which had a like purpose. The same action was taken by North Dakota in 1921. In addition to those engaged as instructors in the public schools, Nebraska included teachers in private and parochial institutions. In Washington, California, and Michigan the privilege of a license was granted to those aliens who declared their intention of becoming citizens, and in Washington in addition there were included those teachers whose certificates or diplomas had been revoked on account of a failure to impress upon the minds of the pupils "the principles

${ }^{19}$ Constitution of Louisiana, art. 251; Lares of Nerw Mexico (1923), sec. 1418, p. 325.

${ }^{20}$ Lares of New York (1917), chap. 146, par. 568, II, 1280.

${ }^{21}$ Ibid. (1919), chap. 120, 3, p. 218; ibid. (1918), chap. 158, pp. 550, 749; ibid. (1921), par. 555a, III, 2048. 
of patriotism or to train them up to a true comprehension of the rights, duty, and dignity of American citizenship.."22

An open declaration of loyalty and of an intention to inculcate patriotism in their pupils was required of all teachers by Ohio in a law of 1919, by Colorado, Nevada, Oklahoma, Oregon, and South Dakota in 1921. In Ohio, Colorado, Oklahoma, Arizona, and South Dakota teachers, not only in the public schools, but in private and parochial schools were forced by law to take an oath to support the constitution of the state and of the United States and to obey their laws. The Ohio law prescribed an "undivided allegiance to the government of one country, the United States of America," and Colorado and Oregon adhered to the same principle. ${ }^{23}$ Nevada's law of 1921 required of teachers paid by the state the oath in her constitution, prescribed for all public officers. ${ }^{24}$

In addition to the regulations imposing an oath of allegiance on teachers, South Dakota, like Washington, in her law included a prohibition of treasonable utterances. The Law declared:

Any teacher who shall have publicly reviled, ridiculed or otherwise spoken or acted with disrespect or contumacy towards the flag of the United States or its official uniforms or insignia, or towards the system of government of the United States, or its Constitution, or shall refuse to take and subscribe to the oath of allegiance hereinbefore required, shall thereafter be forever disqualified to teach in any public or private school within this state, and the certificate of

${ }^{22}$ Lares of Washington (1919), sec. 1, p. 82; Lares of Nebraska (1919), chap. 250, sec. 1, p. 1020; Acts of Michigan (1919), No. 220, sec. 1, p. 392 ; Lares of Tennessee (1919), chap. 91, p. 223; Compiled Statutes of Idaho (1919), par. 946, I, 270. Idaho, in her Lazes of 1921, has another enactment, but it has the same purpose (Lares [1921], sec. 77, p. 464). Lares of Montana (1919), chap. 196, sec. 18, p. 429, amending law of 1905, by which any teacher holding a certificate and not a citizen was given time (six months) to declare his intention. Political Code, chap. 77, sec. 1912, p. 167. For California's law see School Law of California (1921), p. 203. Lazes of North Dakota (1921), chap. 111, p. 90. Mississippi and Maryland aliens were not permitted to teach following the war.

${ }^{23}$ Lares of Ohio (1919), supplements 7852 of General Code, sec. 7852-1, p. 514. Lares of Colorado (1921), chap. 213, sec. 1, p. 719; Lares of Oregon (1921), chap. 115, p. 226.

${ }^{24}$ Statutes of Nevada (1921), sec. 38, p. 303. 
any such teachers shall be revoked by the Superintendent of Public Instruction upon satisfactory proof of the commission of any such offense. ${ }^{25}$

An Oklahoma statute excluded from all public and private schools of that state persons "guilty of teaching or inculcating disloyalty to the United States or of publicly reviling the flag, or the system of government of the United States." Yet the statute prescribes that "criticism of any public official shall not be construed as within the purview" of this regulation. ${ }^{26}$

Thus the legislature through prohibitive decrees attempted to block and direct the speech of teachers as well as to make the personnel of the teaching corps purely American. This form of legislation again illustrates the temper of the lawmaker toward Americanism and is not different from that so plainly evident in many other laws passed since $191 \%$.

\section{OBSERVANCE DAYS}

In the public school, the legislator has also decreed, shall be observed those days which may be commemorative of historic personages and events. Avowedly such legislation is designed to foster patriotism, and many states have indulged in this method of developing a patriotic citizenry. The display of the flag upon public buildings, ceremonials to pay homage to the flag, exercises to commemorate the achievements of American "statesmen and patriots," 27 and the singing of the national anthem at prescribed periods are frequently enjoined upon teachers by official fiat. ${ }^{28}$

${ }^{25}$ Lares of South Dakota (1921), chap. 210, p. 317.

${ }^{28}$ Oklahoma School Lares (1923), p. 18; Acts of Oklahoma (1921), chap. 15 , sec. 2, p. 141.

${ }^{27}$ See Lares of Minnesota (1917), chap. 108, sec. 1, p. 135. The law prescribed one-half hour daily for "exercises tending to promote and inculcate patriotism."

${ }^{28} \mathrm{See}$, for example, Lazes of Maryland (1918), chap. 75, sec. 1, 176a, p. 121 ; ibid. (1920), chap. 381 , sec. 1, p. 665 . Acts of Oklahoma (1921), chap. iii, p. 137. Revised Statutes of Maine (1916), chap. 16, sec. 52. The celebration through patriotic exercises of the birthdays of Washington and Lincoln is found, for instance, in Wisconsin. Lares of Wisconsin (1923), chap. 337. October 12 and November 11 in North Dakota (Educational Lares of North Dakota [1923], chap. 2821, p. 45). In addition to those previously prescribed, Michigan observes Roosevelt's birthday and November 11 (General School Lares of Michigan [1923], p. 107). 
Since 1918 November 11 has served as a time in which special exercises are to be held to recall the part taken by the United States in the World War and to set forth "the principles for which the allied nations fought." ${ }^{29}$ A resolution of the legislature of Maryland in 1920 memorialized the president of the United States to make this date a day for "national thanksgiving," because it was the time when "there terminated that war which overthrew the human monster who laid blood-hands upon nearly every home of a peace-blest earth.",30

Special days are occasionally set aside to engage in some formality intended to emphasize the rights and privileges of American citizens. Thus South Dakota (1921) declared that Memorial Day be known as "Citizenship Day," at which time each citizen who has become twenty-one years of age during the year, or who has been admitted into full citizenship of the United States during that period, shall receive a "citizenship certificate signed by the Governor, attested by the Secretary of State, and countersigned by the chairman of the Board of County Commissioners of the County in which such citizen resides." Accompanying the certificate is a "manual of citizenship" containing "the Mayflower Compact, the Declaration of Independence, the Constitution of the United States and of South Dakota," and "nonpolitical axioms and discussions of the principles of popular citizenship."31

Laws showing local as well as national patriotism are occasionally found. "Rhode Island Independence Day" is one of this kind. First proclaimed in 1908, it has become the occasion for patriotic ceremonies held on May $4 .^{32}$ In North Carolina, the twelfth of October is devoted to appropriate exercises in the public schools, "to the consideration of some topic or topics of state history."33 Oklahoma has decreed that November 16 be

${ }^{29}$ Session Laws of the State of Washington (1921), chap. 56, sec. 1, p. 171. See also School Law of West Virginia (1923), p. 32.

${ }^{30}$ Lares of Maryland (1920), pp. 1448-49.

${ }^{31}$ Lares of South Dakota (1921), chap. 144, secs. 1, 2.

${ }^{32}$ Acts and Resolves, of Rhode Island (1914), chap. 1071, sec. 2, p. 1104.

${ }^{33}$ Public School Law of North Carolina (1923), Part XIII, art. 38, sec. 367 . 
celebrated in such a manner as to teach "loyalty and patriotism" to state and Union. ${ }^{34}$ Other states at a time previous to the World War have enacted similar laws. ${ }^{35}$

In a few cases in which the law requiring celebration of observance days or compliance with a fixed ceremonial has been enforced, objections have been reported. According to the Social Service Bulletin of December 1, 1926, "In early 1926 fifty children of the Jehovites in Denver were expelled for refusing to salute the American flag. The Jehovites maintain that they respect the law and the flag, but they are opposed to saluting the flag as a symbol of temporal power. The Denver School Board has now waived the compulsory patriotic exercise ruling, and has readmitted the children to school. In Bellingham, Washington, a nine-year-old boy was taken permanently from his home and given out for adoption by 'Christian patriotic parents,' because the religious scruples of his parents forbade him to salute the flag in school exercises. The same scruples forbid them to take the case to court."

${ }^{3}$ School Lares of Oklahoma (1923), p. 69.

${ }^{35}$ For example, "Georgia Day" on February 12, "South Carolina Day" on March 18, "Maryland Day" to be named by the State Board of Education, "Pioneer Day" in Montana, "Minnesota Day," and "Grand Army Flag Day" in Rhode Island, among others.

${ }^{*}$ Social Service Bulletin, XVI (December 1, 1926), 1. 


\section{CHAPTER XXIV}

\section{COURSES OF STUDY}

\section{COURSES OF STUDY PREPARED BY STATE DEPARTMENTS OF INSTRUCTION}

Both through legislative mandate and through personal initiative, state superintendents of public instruction in many states have issued courses of study for use in the schools. These are designed to provide a guidance for teachers, and are used to the greatest degree, undoubtedly, in the rural schools and in the schools of the small cities. City systems often provide separate manuals for the work carried on in their schools.

Besides suggestions of different kinds as to the content of the courses and the methods of carrying on instruction occasionally found, aims and objectives are usually set forth. Here there is found a similarity of thought but a variety of expression. In geography, the interdependence of people is usually stressed; in civics, the knowledge of governmental structure and a training in the duties and privileges of citizenship; in American history, the inculcation of loyalty to country through a study of the past and an understanding of American nationality. In general, history, it is believed,

fosters the spirit of patriotism which puts right above might, and produces a more unselfish, social individual. . . . A study of the noble, worthy deeds of great men and women and the achievements of nations in any age, gives lessons of loyalty and duty to the nation, a desire for service that neither doubts, nor counts the cost, nor asks recognition, a service that means sacrifice. ${ }^{1}$

\section{GEOGRAPHY}

Like textbooks, courses of study in geography stress to a greater degree than those in allied fields the interdependence of people. ${ }^{2}$ Frequent mention is made of the possibilities of the sub-

${ }^{1}$ State Course of Study Montana City Elementary Schools, p. 389.

${ }^{2}$ See, for example, General Course of Study for Arizona Schools, p. 73; New Mexico Common Schools Course of Study (1923), p. 57. 
ject to develop "a sympathetic understanding of other peoples,"3 as well as "an appreciation of our indebtedness to the nations of the world for our citizens, our institutions, our history, our art, our literature and for many comforts now enjoyed." 4 In the development of a sympathetic attitude toward other peoples manuals suggest not only the promotion of understanding through spiritual contacts but through commercial intercourse. Attention is directed toward the interest of America not only in the world in general, but toward her interest in certain countries. For example, the Montana course emphasizes not only the indebtedness of America to Europe, but points out a special friendliness felt for France. "Why are Americans so deeply interested in France?" is asked. In answer there are mentioned: "Our admiration for the bravery and sacrifices of the French. Our debt to France. Part Lafayette and the French nation played in securing our freedom." The aid of Europeans and Americans to the people of Asia and the relationships through products and political ties of countries to each other receive attention in this manual. Nor are pupils permitted to leave unnoted the concept of freedom embodied in the name America and the wealth and prosperity evident in the United States. ${ }^{5}$

\section{COURSES IN CITIZENSHIP}

The objectives set forth for the teaching of political problems, or civics, have in common the aim of "good" or "intelligent citizenship." Just what these terms mean is generally left unsettled for the teacher, for they are seldom defined. Obviously this might result in as many different concepts for the pupil as there are different interpretations by different teachers.

${ }^{3} A$ Course of Study in the Social Studies (Connecticut), p. 3. See also Courses of Study in Junior and Senior High Schools (Missouri), Bulletin No. 1 (1925); A Course of Study for the Elementary Schools of Wisconsin (1923), p. 85; Curriculum for Elementary Schools of Minnesota (1923), p. 350; Manual and Courses of Study for Elementary Schools (Pennsylvania), p. 266.

"Utah Course of Study for Secondary Schools ("The Junior High School"), p. 75. See also State Course of Study Montana City Elementary Schools, p. 534.

${ }^{5}$ Ibid., pp. $486-87$. 
The Connecticut course has as its fundamental aim in all the social studies the development of "an intelligent citizenship of cooperation and service," and specifies for citizenship courses the incorporation of "knowledge of the civic duties, responsibilities, and privileges of the intelligent, co-operative citizen." general, the ultimate aim of courses in civics is "the making of better citizens in the home, in the community, in the state, in the nation."7

The values of the American form of government, love for country, respect for law, and the need of an intelligent citizenry receive emphasis. Thus, according to the Missouri course for elementary schools :

The great end of our government, the service of all the people, should be emphasized at every point. While no attempt should be made to mislead the pupil into the false view that no further improvement can be made in our local and general systems, the whole of democratic government, and the need of loyal co-operation with it are repeatedly demonstrated.

The bulletin makes a special plea that reverence for the law be taught since "no child is too young to be a patriot or to be taught the responsibilities of a good citizen."8

In this course of study, as in other manuals, there are frequently established, besides the general objective, aims for different grades. For instance, the care of property is stressed in the first year of the Missouri course; the second grade is to touch upon the sacrifice of pioneers in establishing a free government in America; the third is to tell stories "illustrative of the blessings that arise under our form of government as compared with hereditary monarchy"; the fourth year is "to teach the story of our flag, the number of stars and stripes, the significance of each, the colors on the flag and the significance of each color."

- (Connecticut) A Course in the Social Studies, p. 3.

' (Iowa) McClenahan, Course in American Citizenship, I-III, pp. 4, 5, 7, 9.

- State Course of Study for the Elementary Schools in the State of Missouri, pp. 157-58. See also State of Oklahoma, Course of Study for the Common Schools, p. 59; General Course of Study for Arizona Schools, pp. 27-28. 
The pupils are to "read the story of Betsy Ross." In the fifth grade the pupils are

to see a nation rise because its citizens were temperate, frugal, just, honest, brave, and loyal; to see a nation remain intact for centuries, increasing its territory and governing wisely because of good laws, industry and the spread of knowledge and loyalty; to see a nation fall, as soon as its people become indolent, seeking individual advantages regardless of the group's good. . . . .

The directions continue for the fifth grade as follows:

Learn to sing and commit to memory, "My Country 'Tis of Thee." Teach the history of the American flag. By means of suitable reading matter and stories inculcate in all a clear comprehension of the difference between our form of government, a government by the people, and its opposite, a hereditary monarchy. Give suitable lessons that show the blessings that arise from our form of government and show through what struggles the early settlers in America passed in order to establish freedom and independence.

In the sixth grade of the Missouri course it is suggested that children "trace, the early struggles of the people for recognition and give especial attention to such events as mark the turning point in the development of freedom." A further task for the sixth-year teacher is to teach so that there is "the recognition of what each nation contributes to American ideals," thus making "broader sympathy, better cooperation, and greater unity of purpose." The next year the pupils are to "study and memorize the poems 'The American Flag,' 'My Flag and Your Flag.", They are to be taught obedience to authority in the home, the school, the country, the state, and the nation.

The eighth grade of this course enjoins committing to memory and learning to sing "The Star Spangled Banner." Here the children are to be taught "the importance of complete loyalty to the principles for which our government stands," as well as the meaning and necessity of government. ${ }^{9}$

In short, it is the special desire of curriculum makers in citizenship to cultivate right civic habits, to create high civic ideals, and to develop, by means of service, a finer patriotism and a

${ }^{\circ}$ Ibid., pp. 158-61. See also Course in Florida. 
larger democracy, ${ }^{10}$ as well as the "belief that our democratic government is the best kind of government for Americans and that it is our duty to defend it against all enemies."11

\section{HISTORY}

Most makers of courses of study are united in their belief that the main aim of instruction in American history is the development of a vivid conception of American nationality and a high sense of patriotism and civic responsibility. "It is our task to teach more adequately and thoroughly than in the past the peculiar and characteristic genius of American institutions and the permanent and outstanding assets of our democracy." ${ }^{12}$ Through such instruction, it is held, a much desired patriotism will result. According to one manual,

Patriotism, the greatest of our national ideals, comprehends all the rest. Love of country is a sentiment common to all peoples and ages; but no land has ever been dearer to its people than our own America. No nation has a history more inspiring, no country has institutions more deserving of patriotic love. Turning the pages of our nation's history, the young citizen sees Columbus, serene in the faith of his dream; the Mayflower, bearing the lofty soul of the Puritan; Washington, girding on his holy sword; Lincoln striking the shackles from the helpless slave; the Constitution, organizing the farthest west with north and south and east and into one great Republic the tremendous energy of free life trained in free schools, utilizing our immense natural resources, increasing the nation's wealth

${ }^{10}$ Commonwealth of Pennsylvania, Department of Public Instruction, Manual and Courses of Study for Elementary Schools, p. 107. See also High School Manual for South Dakota, p. 123; Syllabus for Elementary Schools (New York), p. 5; Courses of Study for the High Schools of Oregon, p. 21; Commonwealth of Massachusetts, Plan for the Study of the Constitution, Bulletin No. 4 (1924), p. 2; State of Mississippi, Department of Education Bulletin No. 29 (1924), High Schools, pp. 111-12; A Manual for the High Schools of Wisconsin (1924), p. 150; Course of Study for the Elementary Schools of Florida, pp. 153, 172; State Course of Study (Montana), p. 475; Manual for Georgia Teachers, p. 154; State of Oklahoma, Course of Study for the Common Schools, p. 59; General Course of Study for Arizona Schools, pp. 27-28.

11 (Massachusetts) Bulletin (1924).

${ }^{12}$ Manual and Courses of Study for the High Schools of Idaho, p. 73. 
with the aid of advancing science, multiplying fertile fields and noble workshops, and busy school systems and happy homes.

This is the history/for which our flag stands; and when the young citizen salutes the flag, he should think of the great ideals' which it represents. The flag stands for democracy, for liberty under the law; it /stands for heroic courage and self-reliance, for equality of opportunity, for self-sacrifice, and the cause of humanity. It stands for free public education, and for peace among all nations. ${ }^{13}$

The influence of heroic characters is held an important factor in the development of responsible citizenship and patriotism by the authors of manuals in Idaho, Georgia, Florida, Colorado, Missouri, Massachusetts, Pennsylvania, and Utah. ${ }^{14}$ With this in mind, manuals on patriotism and special observance days have been prepared by some states. Among these North Dakota, South Dakota, Oklahoma, New Jersey, and Maryland have placed before their teachers suggestive lessons and programs for such days as Washington's and Lincoln's birthdays, Memorial Day, and Armistice Day.

The Georgia manual expresses the general sentiment as to the value of teaching the achievements of heroic characters in history:

A study of the men and women who have made the present what it is by their deeds in the past offers a splendid opportunity for the development of the fundamentals of Citizenship and Americanization. Teaching patriotism, a sense of brotherhood, a devotion to law and order, a harmony of all the good elements of citizenship in the "citi-

${ }^{13}$ Idaho Bulletin of Education, Courses of Study for the Public Schools of Idaho (1923), p. 35, quoted from Guitteau's Preparing for Citizenship. See also Course of Study for the Elementary School of Florida, p. 171, seventh-grade history.

${ }^{14}$ Idaho Bulletin of Education, op. cit., pp. 88-89; Manual for Georgia Teachers, pp. 130, 193 (eighth grade); Course of Study for the Elementary Schools of Florida; Colorado Course of Study in Education, pp. 182-83; State Course of Study for the Elementary Schools (Missouri), p. 122; Massachusetts, Teachers' Manual of United States History for Grades VII and VIII (1922), p. 11; Commonwealth of Pennsylvania Department of Public Instruction, Manual and Courses of Study for Elementary Schools, p. 115; Utah Course of Study for Secondary Schools, p. 65. 
zen of the future" should be among the chief aims of the teacher of history. ${ }^{15}$

Several manuals suggest the development of a loyalty toward, and a responsibility for, humanity in general as an aim of history and its allied subjects. One of the pledges of loyalty in the Missouri course stresses the desirability of friendly relations between the United States and foreign countries. ${ }^{16}$

At this point it may not be inappropriate to mention the efforts of the World Federation of Education Association, especially as they touch the teaching of history and the development of international good will. Through this group, organized under the auspices of the National Education Association, World Good Will Day on May 18, the date of the opening of the first Hague conference, has been proclaimed. Upon this day, exercises to develop a spirit of international fellowship are held, including pageants, plays, music, essays, and compositions. ${ }^{17}$

The same organization in $\mathbf{1 9 2 5}$ affirmed "its belief that geography, history, and training in citizenship should be taught not only from a national point of view but also from a modern sociological and international point of view." 'They also asserted "that textbooks descriptive of child life in all lands and setting forth in brief and simple form the best that each nation has achieved be prepared for the elementary schools of the world."18

The National Education Association is also definitely associated with "America Education Week," which has for its primary purpose a dedication of all the people to "the task of universal education." During this time, programs arranged by the American Legion, the United States Bureau of Education, and the

${ }^{15}$ Manual for Georgia Teachers, p. 130.

${ }^{16}$ State Course of Study for the Elementary Schools in the State of Missouri, p. 164. See also Course of Study for Elementary Schools of Oregon; Manual and Courses of Study for Elementary Schools (Pennsylvania); Course of Study for High Schools of Arkansas; Utah Course of Study for Secondary Schools.

${ }^{17}$ See Augustus A. Thomas, "Good Will Day, May 18," Journal of the National Education Association, XV (April, 1926), 111-12.

18 "World Federation Resolutions," Journal of the National Education Association, XIV (October, 1925), 218-19. 
National Education Association offer suggestions for exercises in the schools for each day of the week. Officials of the public schools, posts of the American Legion, state educational institutions, and other co-operating organizations are prepared each year to furnish speakers. ${ }^{19}$

\section{COURSES OF STUDY IN CITY SCHOOL SYSTEMS}

City school systems, in general, do not publish extensive courses in the social studies but leave to the teachers of those subjects the direction of the work. When data on the work given are available, they are often of an experimental and temporary character. It may be said that on the whole the subject matter presented varies but slightly from that of the state course or the prescribed textbook.

St. Louis and Denver are two cities which recently embarked on projects of curriculum revision in which they have! set up objectives whose nature is such as to be considered here. Both point out the need of developing a social attitude. Through emphasis on industrial and commercial relationships, the interdependence of peoples is stressed. The St. Louis course specifically mentions as one of its aims "to develop a sense of membership in the world community," and both courses propose to develop an understanding and an appreciation for the social and civic ideals of America. ${ }^{20}$

Other city courses have similar purposes. Boston, in her Course in Citizenship through Character Development, for instance, teaches "obedience to duly constituted authority," "loyalty to home, to school, to country, to faith." "21 Under the Law

19 "American Education Week-1925," Journal of the National Education Association, XIV (October, 1925), 227.

${ }^{20}$ Public Schools, Denver, Colorado, Course of Study Monograph No. 3: Social Science; Board of Education, St. Louis, Social Studies Curriculum Bulletin Nos. 6, 13, 25, 26, 2\%, 28, 29. See also Department of Education, City of Baltimore, The Social Studies Course of Study for Senior and Junior High Schools, pp. 323, 383.

${ }^{21}$ School Document No. 10 (1924), Boston Public Schools, Course in Citizenship through Character Development Grades I to VIII (Boston, 1924). 
of Loyalty there is pledged loyalty to humanity, in which is asserted a willingness to do one's best "to help the friendly relations of our country with every other country."22 The Lake County, Indiana, social studies course stresses obedience to law and has as one objective the development of "a sense of group consciousness and of human interdependence," an objective frequently found in manuals for geography. ${ }^{23}$

In some courses of study attention is directed toward attributes alleged to be primarily American. Such an aim is found in the Syllabus for High Schools and Junior High Schools, First Year Civics, in New York, in which is expressed a desire "to inculcate American ideals." Among these ideals are listed democracy; equality of opportunity and equality before the law; majority rule with recognition of the rights of minorities to further their ideals by lawful methods; responsibility of public officials to the people whose chosen agents they are; legal processes for changing our laws and governmental institutions; freedom of the press, of speech, of assembly, of religion, for all; a broad citizenship, with undivided allegiance; universal free education; local self-government, representative government when direct government is not practicable; a fair and public trial for all. ${ }^{24}$

Sioux City, Iowa, through her superintendent, M. G. Clark, has issued a course of study in history, called Progress and Patriotism, in the hope that it may be instrumental in leading children to the acceptance "of an intelligent and loving service for their city, their state, their nation, and for humanity."25 In the "spiritualization of the facts," each unit of the course in every grade throughout the entire system is known by its own peculiar patriotic study name. It is hoped, throughout the system, that "these names may come into familiar use and instead of speaking of the ${ }^{22}$ Ibid., p. 31.

${ }^{23}$ Department of Superintendence Fourth Year Book, The Nation at Work on the Public School Curriculum, pp. 332-33, 337, 341. See, for example, the Cleveland, Ohio, course of study.

${ }^{24}$ Syllabus for High Schools and Junior High Schools: First Year Civics, City of New York (1923), p. 2.

${ }^{25}$ M. G. Clark, Progress and Patriotism (Bloomington, Illinois, 1923), dedication page. 
first grade, the second grade, the third grade, we will speak of them by their patriotic name." For this purpose, in Patriotic Studies, "the Kindergarten group is known as the 'Home Patriots.' The first grade is known as 'The Red, White and Blue,' the second grade as 'The Washington Room,' the third grade as 'The Lincoln Room.',"26

In Indianapolis, the Course of Study in American Citizenship ascribes to such a course the creation of "an interest in and an understanding of the place of his nation in the scheme of events." and the development of "a firm sense of responsibility for honest, intelligent, and aggressive participation in public affairs."

Some city systems have definitely undertaken through instruction in social studies to secure good international understanding. For example, the Deering High School, of Portland, Maine, endeavors to show the progress of civilization in art, science, and literature, among other things, in which mankind as a unified group has a part. $^{28}$

Education for international good will is characteristic especially of Quaker schools. Such reading lists as those proposed by W. Walker Cheyney, of the Baltimore Friends' School, are typical of the reading done in these schools. ${ }^{29}$ According to $\mathrm{Mr}$. Walter W. Haviland, principal of the Friends' Select School of Philadelphia, the schools of his religious sect endeavor to emphasize the international idea especially in geography. In history, no peace propaganda is obvious, he holds, but an effort is made to find heroes "who save other people's lives rather than those heroes who take them." Mr. Haviland cited as books expressing this idea Coe's Heroes of Everyday Life and Hyde's Modern Biography. ${ }^{\mathbf{3 0}}$

${ }^{26}$ Ibid., p. 36.

${ }^{27}$ Indianapolis Public Schools, Course of Study in American Citizenship (1922), p. 9.

${ }^{28}$ Personal letter.

${ }^{20} \mathrm{~W}$. Walker Cheyney, "Education for International Goodwill, A Study of the Will to Friendship and Some Suggestions as to Its Development" (Philadelphia: Friends' Peace Committee, 1925).

${ }^{30}$ Personal conference, March 12, 1926. 
Some of the public and secular private institutions carry on work of a like nature. In Miss Kearns' School for the Deaf at East Twenty-fourth Street in New York, touch with the outside world is maintained by the pupils writing to classes in Belgium, Germany, Denmark, and other countries. Sometimes Christmas presents are exchanged, and there is established "a spirit of camaraderie and mutual helpfulness that transcends national boundaries."31

The following letter illustrates the work done:

270 East 24 Street

New York City

March 18, 1926

Dear Betty:

I received your letter that you sent me. I thank you very much.

We thank you very much for sending us some beautiful pictures which were painted by some boys in your school. We have one of them hanging on the wall. It shows beautiful trees and mountains and rippling water and grass. All the time we see it.

My parents were born in Spain. I was not born in Spain but in America. I have three brothers and no sisters.

I know how to dance Spainish [sic] and Dutch dances and the Charleston. Do you know how to dance? I know how to swim, skate, sew, read and do many other things.

Would you like to come to New York? If you come to New York maybe I will meet you. If I meet you I will show you how to dance. How old are you? What grade are you? I hope you will write me another letter and answer my questions.

Your loving best friend,

MARY TELLUS

The sending of dolls at Christmas time to Japanese children is a project of international amity sometimes practiced. Destined to be messengers of good will, the dolls are distributed in the public schools by the Japanese government. Much of this work has been sponsored by the Committee on World Friendship among Children of the Federal Council of the Churches of Christ in America, and has a purpose similar to the international undertaking of such groups as the Junior Red Cross.

${ }^{31}$ The Public and the School, No. 253, March 9, 1926, p. 6. 


\section{CONCLUSION}

Never in the history of the world has there been such interest in education as there is at the present time. The World War did much to bring this about. Of the 2,000,000 men drafted into the army in 1917, about 200,000 could not understand the English language - a condition undreamed of by the layman, who thought education not only free and universal, but also compulsory.

This, with other forces, tended to awaken men to the necessity of renewed interest in the functions and possibilities of the school. This interest spread in many directions, chief of which was an appraisal of the character of the public-school curriculum. Abetted by a zealous patriotism, individuals and organizations took up the matter and entered the ranks of those demanding an educated citizenry. As the number of crusaders increased, the purposes of education enlarged to include many points of view. It was soon recognized that what was taught the boy and girl became stock in trade and made up the "accumulated memories" with which later they might ply their trades, and with which they could combat any forces held insidious to the development and welfare of the nation. Following the war the feeling of kinship with some of the peoples of the world quickened by an alliance of arms in a common cause was superseded by an intensified nationalism. While the war raged the American people would have unanimously indorsed Goethe's belief that above the nation is humanity. Following the war this belief became a shadow, and people in general reverted to the attitudes of pre-war days.

Many of these attitudes are the result of instruction in the schools and the knowledge gained from textbooks. "The average man's notion of a Frenchman or of a German or of an Irishman or of a Jew is gotten not from extensive personal observation but from anti-types supplied by versifiers, story-tellers, and playwrights," says Carlton Hayes, in his Essays on Nationalism. ${ }^{1}$

${ }^{1}$ Carlton J. H. Hayes, Essays on Nationalism (New York, 1926), p. 67. 
And to the list might be added the writers of history and other textbooks commonly used in the schools.

From the analysis of nearly four hundred textbooks representing different subjects taught in the schools, the conclusion inevitably must come that the American is taught to respect and venerate his forebears and the institutions which they designed and developed. Textbooks are permeated with a national or patriotic spirit. Most books are pro-American. None can be charged with disloyalty to American ideals. Nor is there frequent criticism of American characteristics or of American activities. Indeed, the Preface of one history avows as its purpose a sentiment which is characteristic of many books :

The future of our country is in the hands of our school boys and our school girls. May they realize our country's greatness, with its opportunities, and their own individual responsibility in preserving and enlarging and maintaining both. May they follow the course and keep the faith of the fathers remembering that America is a great cause and not a result. When Americans once agree upon any course or any cause, the united world cannot conquer them. ${ }^{2}$

On the other hand, the attitudes engendered toward other peoples through a reading of these books must, in many cases, redound to their ignominy in contrast with the glory of America. The Spaniard in histories is pictured as harsh and cruel, and, from a reading of many of the books, one is forced to inquire, "Was there no good in the Spaniard?" England, although receiving far more generous treatment than in the histories and readers of twenty-five years ago, still is not accorded glowing praise. The animosities kindled by the Revolution, the War of 1812, and the attitude of England toward the North in the Civil War are still evident in some books. Present-day critics of textbooks who charged a pro-British bias in writers could have read only scantily. True it is that reputable historians and others have endeavored to set forth both sides of controversial questions, and of late there has been a decided development of the spirit of fair play. Nevertheless the books are not pro-British. They may not be anti-British. Perhaps we may best call them pro-American.

${ }^{2}$ Daffan, History of the United States. 
The charge of pro-British prejudice, so frequently heard within the last few years, may have arisen from the effort of these writers to portray events as impartially as possible. When read by persons still holding the animus aroused by the older type of history and reader, they undoubtedly seem "un-American." As Anatole France said, "If you have any new insight, any original ideas, if you present men and affairs under an unwonted aspect, you will surprise the reader. And the reader does not want to be surprised. He seeks in history only the stupidities with which he is already familiar."

As England has been considered the traditional enemy of America, so has France been held the traditional friend. Of all nations, France receives the most praise. In sharp contrast is the treatment accorded in most books to Germany. Militarism, greed, rapacity, and cruelty are charged against her. Of the countries of the Far East, China is used often as an example of American generosity to a weaker nation. On the other hand, Chinese immigrants to this country are not pictured in a favorable manner. Similar treatment is accorded the Japanese immigrant, although to Japan is ascribed a progressive spirit unknown in China.

In general, the peoples of South America are mentioned in connection with discussions of the Monroe Doctrine generally held not only necessary but beneficial. As in the case of the dependencies of America, the United States is described as generous in spirit in her relations with weaker peoples and as a benefactor of mankind. Mexico is given scant praise.

Of all the books examined, geographies are the least inclined to paint the American as superior to other peoples, readers and histories being the most guilty in this respect. Moreover, many books do not preach a brotherhood of man, and the emphasis on war heroes and incidents is such as to exalt war over peace. One is reminded of a passage from Shakespeare's Merchant of Venice as he considers the attitudes which may be gained from some of the books in common use.

Hath not a Jew eyes? Hath not a Jew hands, organs, dimensions, senses, affections, passions? fed with the same food, hurt with the 
same weapons, subject to the same diseases, healed by the same means, warmed and cooled by the same Winter and Summer, as a Christian is? If you prick us, do we not bleed? if you tickle us, do we not laugh? If you poison us, do we not die? and if you wrong us, shall we not revenge? if we are not like you in the rest' we will resemble you in that.

Nor do textbooks fail to advocate a loyalty to the government of this country. Especially do books in civics or citizenship set forth the rights, privileges, and duties of citizens and admonish the maintenance of ideals held American. Because of freedom of opportunity, the right of liberty, life, and property, the pupil is taught that he owes a sturdy allegiance to a democratic and just government through whose protection he is enabled to possess these blessings.

It has not been the purpose of this study to advocate what the content of textbooks should be. Its purpose has been to set forth only the facts. In view of the period of life in which most of these books are read by the child, the question, however, arises as to the character of ideals and attitudes which should be established in this plastic stage of development when many impressions become indelibly fixed. "The chief part of man's life is remembering," said James Harvey Robinson. What do the American people wish their children to remember? 


\section{LIST OF BOOKS ANALYZED}

TEXTBOOKS IN HISTORY

American School Citizenship League. An American Citizenship .Course in United States History, Course with Type Studies, Book I for Grades IV and V. New York: Charles Scribner's Sons, 1921.

- An American Citizenship Course in United States History, Course with Type Studies, Book Two for Grade VI. New York: Charles Scribner's Sons, 1921.

- An American Citizenship Course in United States History, Course with Type Studies, Book Three for Grade VII. New York: Charles Scribner's Sons, 1921.

- An American Citizenship Course in United States History, Course with Type Studies, Book Four for Grade VIII. New York: Charles Scribner's Sons, 1921.

Atrinson, Alice M. The European Beginnings of American History.

Boston: Ginn \& Co., 1912.

Barker, Eugene C.; Webb, Walter P.; and Dodd, William E. The Growth of A Nation: The United States of America. Evanston: Row, Peterson \& Co., 1928.

Barnes, Everett. Short American History by Grades, Part II. Boston: D. C. Heath \& Co., 1922.

- American History for Grammar Grades. Boston: D. C. Heath \& Co., 1923.

Beard, Annie E. S. Our Foreign Born Citizens. New York: Thomas

Y. Crowell Co., 1922.

Beard, Charles A., and Bagley, William C. A First Book in American History. New York: Macmillan Co., 1922.

- The History of the American People. New York: Macmillan Co., 1923.

- Our Old World Background. New York: Macmillan Co., 1922.

Beard, Charles A., and Beard, Mary R. History of the United States. New York: Macmillan Co., 1925.

Bemis, Katherine Isabel; Holtz, Mathilde Edith; and Smith, Henry Lester. The Patriotic Reader. Boston: Houghton-Mifflin Co., 1917. 
Blaisdell, Albert F., and Bald, Francis K. American History for Little Folks. Boston: Little, Brown \& Co., 1917.

- The Child's Book of American History. Boston: Little, Brown \& Co., 1913.

Bourne, Henry Eldridge, and Benton, Elbert J Jy. American History. Boston: D. C. Heath \& Co., 1925.

- A History of the United States. Boston: D. C. Heath \& Co., 1921.

—. Introductory American History. New York: D. C. Heath \& Co., 1916.

- Story of America and Great Americans. Boston: D. C. Heath \& Co., 1925.

Burnham, Smith. The Making of Our Country. Philadelphia: John C. Winston Co., 1920.

- Our Beginnings in Europe and America. Philadelphia: John C. Winston Co., 1918.

Cather, Katherine. Boyhood Stories of Famous Men. New York: Century Co., 1916.

Channing, Edward. A Students' History of the United States. New York: Macmillan Co., 1922.

Channing, Edward, in consultation with Susan J. Gins. Elements of United States History. New York: Macmillan Co., 1919.

Coe, Fanny E. Founders of Our Country. New York: American Book Co., 1912.

Daffan, Katie. History of the United States. Ennis, Texas: Katie Daffan, Publisher, 1924.

Davis, William Stearns. Medieval and Modern Europe. Boston: Houghton Mifflin Co., 1920.

Eggleston, Edward. A First Book in American History. New York: American Book Co., 1920.

Elson, Henry W. Modern Times and the Living Past. New York: American Book Co., 1921.

- United States: Its Past and Present. New York: American Book Co., 1926.

Estill, Harry F. The Beginner's History of Our Country. Dallas, Texas: Southern Pub. Co., 1919.

Evans, Lawton B. The Essential Facts of American History. Chicago: Benjamin H. Sanborn \& Co., 1920.

Fish, Carl Russell. History of America. New York: American Book Co., 1925. 
Fite, Emerson David. History of the United States. New York: Henry Holt \& Co., 1926.

- The United States. New York: Henry Holt \& Co., 1923.

Forman, S. E. Advanced American History. New York: Century Co., 1924.

Franciscan Sisters of the Perpetual Adoration. A History of the United States for Catholic Schools. Chicago: Scott, Foresman \& Co., 1914.

Garner, Alfred W., and Henson, Clarence C. Our Country's History. Indianapolis: Bobbs-Merrill Co., 1921.

Gordy, Wilbur Fisk. American Beginnings in Europe. New York: Charles Scribner's Sons, 1925.

- History of the United States. New York: Charles Scribner's Sons, 1922.

—. Stories of Early American History. New York: Charles Scribner's Sons, 1913.

- Stories of Later American History. New York: Charles Scribner's Sons, 1923.

- Stories of American Explorers. New York: Charles Scribner's Sons, 1905.

Gould, F. J. Victors of Peace. New York: Harper Bros., 1915.

Greene, Frances Nimmo. My Country's Voice. New York: Charles Scribner's Sons, 1918.

Guerber, H. A. Story of Our Civilization. New York: Henry Holt \& Co., 1926.

Guitteau, William Backus. History of the United States. Boston: Houghton Mifflin Co., 1924.

—. Our United States: A History. New York: Silver, Burdett \& Co., 1919.

Hall, Robert Green; Smither, Harriet; and Ousley, Clarence. A History of the United States. Dallas, Texas: Southern Pub. Co., 1924.

Halleck, Reuben Post. History of Our Country for Higher Grades. New York: American Book Co., 1923.

Halleck, Reuben Post, and Frantz, Juliette. Our Nation's Heritage. New York: American Book Co., 1925.

Hart, Albert Bushnell. Nerw American History. New York: American Book Co., 1917.

- School History of the United States. New York: American Book Co., 1920. 
Hayes, Carleton J. H., and Moon, Thomas Parker. Modern History. New York: Macmillan Co., 1925.

Hodgdon, Jeanette Rector. A First Course in American History. Book I, Discoverers, Explorers and Colonists. Boston: D. C. Heath \& Co., 1908.

- A First Course in American History. Book II, The National Feriod. Boston: D. C. Heath \& Co., 1922.

Horne, Charles F. The Story of Our American People. 2 Vols.

New York: United States History Pub. Co., 1925.

Hulbert, Archer Butler. United States History. Garden City: Doubleday, Page \& Co., 1923.

James, James Alton, and Sanford, Albert Hart. American History. New York: Charles Scribner's Sons, 1923.

Jones, George J., and Slemon, Emily F. Modern World Setting

for American History. Boston: D. C. Heath \& Co., 1925.

Knowlton, Daniel C., and Howe, Samuel B. Essentials in Modern

European History. New York: Longmans, Green \& Co., 1919.

Latané, John Holiday. A History of the United States. Boston: Allyn \& Bacon, 1921.

Lawler, Thomas Bonaventure. Essentials of American History. Boston: Ginn \& Company, 1918.

Leonard, Arthur R., and J

New York: Henry Holt \& Co., 1924.

Long, William J. America: A History of Our Country. Boston: Ginn \& Co., 1923.

McCarthy, Charles H. History of the United States for Catholic Schools. New York: American Book Co., 1919.

McLaughlin, Andrew C. A History of the American Nation. New York: D. Appleton \& Co., 1919.

Mclaughuin, Andrew C., and Van Tyne, Claude Halstead. A History of the United States for Schools. New York: D. Appleton \& Co., 1923.

McMaster, Јонn Bach. A School History of the United States.

New York: American Book Co., 1920.

McNeat, Edgar Holmes. Modern Europe and Its Beginnings. New

York: Charles Scribner's Sons, 1925.

Mace, William H. A Primary History. Chicago: Rand, MeNally \& Co., 1924.

-. A School History of the United States. Chicago: Rand, McNally \& Co., 1923. 
Mace, William H., and Bogardus, Frank S. History of the United States. Chicago: Rand, McNally \& Co., 1924.

Morris, Charles. Heroes of Discovery in America. Philadelphia: J. B. Lippincott Co., 1919.

Muzzey, David Saville. An American History. Boston: Ginn \& Co., 1923.

- History of the American People. Boston: Ginn \& Co., 1927. Nida, William Lewis. The Dawn of American History in Europe.

New York: Macmillan Co., 1915.

O'Hara, John P. A History of the United States. New York: Macmillan Co., 1919.

Parkman, Mary. Fighters for Peace. New York: Century Co., 1919. Perry, Arthur C., and Price, Gertrude A. American History: First Book (1492-1783). New York: American Book Co., 1914.

Pratt, Mara L. America's Story for America's Children, I, The Beginner's Book. Boston: D. C. Heath \& Co., 1900.

- America's Story for America's Children, II, Exploration and Discovery A.D. 1000 to 1609. Boston: D. C. Heath \& Co., 1900.

- America's Story for America's Children, III, The Early Colonies. Boston: D. C. Heath \& Co., 1901.

. America's Story for America's Children, IV, The Later Colonial Period. Boston: D. C. Heath \& Co., 1901.

- America's Story for America's Children, V, The Foundations of the Republic. Boston: D. C. Heath \& Co., 1901.

- Stories of Colonial Children. Boston: Educational Pub. Co., 1908.

Pumphrey, Margaret B. Pilgrim Stories. Chicago: Rand, McNally \& Co., 1910.

Robrins, Charles L., in collaboration with Elmer Green. School History of the American People. Yonkers-on-Hudson, New York: World Book Co., 1925.

Robinson, James Harvey. Medieval and Modern Times. Boston: Ginn \& Co., 1916.

Rugg, Harold; Rugg, Earle; and Schweppe, Emma. "Town and City Life in America," Social Science Pamphlets, Vol. I, Pamphlet No. 1, "Seventh Grade Series." New York: Harold Rugg, Teachers College, Columbia University.

-. "Resources, Industries and Cities of America," Social Science Pamphlets, Vol. I, Pamphlet No. 2, "Seventh Grade 
Series." New York: Harold Rugg, Teachers College, Columbia University.

- "Industries and Trade Which Bind Nations Together," Social Science Pamphlets, Vol. I, Pamphlet No. 3, "Seventh Grade Series." New York: Harold Rugg, Teachers College, Columbia University.

-. "Industries and Trade Which Bind Nations Together," Social Science Pamphlets, Vol. I, Pamphlet No. 4, "Seventh Grade Series." New York: Harold Rugg, Teachers College, Columbia University.

- "Explorers and Settlers Westward Bound," Social Science Pamphlets, Vol. II, Pamphlet No. 1, "Eighth Grade Series." New York: Harold Rugg, Teachers College, Columbia University. - "The Mechanical Conquest of America," Social Science Pamphlets, Vol. II, Pamphlet No. 2, "Eighth Grade Series." New York: Harold Rugg, Teachers College, Columbia University.

Sheridan, Bernard M. The Liberty Reader. Chicago: Benjamin H. Sanborn \& Co., 1918.

Smith, Harry B. Industrial History. New York: Macmillan Co., 1923.

Stephenson, Nathaniel Wright, and Stephenson, Martha Tucker. A School History of the United States. Boston: Ginn \& Co., 1921.

Tappan, Eva March. American Hero Stories. Boston: Houghton Mifflin Co., 1920.

Thompson, Charles Manfred. History of the United States: Political, Industrial, Social. Chicago: Benjamin H. Sanborn Co., 1922.

Thompson, John Gilbert, and Bigwood, Inez. Lest We Forget. Boston: Silver, Burdett \& Co., 1918.

Thompson, Waddy. A History of the People of the United States. Boston: D. C. Heath \& Co., 1919.

- The First Book in United States History. Boston: D. C. Heath \& Co., 1921.

Thwaites, Reuben Gold, and Kendall, Calvin Noyes. A History of the United States for Grammar Schools. Revised by F. L. Paxson. Boston: Houghton Mifflin Co., 1924.

Tryon, Rolla M., and Lingley, Charles R. The American People and Nation. Boston: Ginn \& Co., 1927.

Vollentine, Grace. The Making of America. Boston: Ginn \& Co., 1925. 
Wells, Louis Ray. Industrial History of the United States. New York: Macmillan Co., 1923.

West, Ruth, and West, Willis Mason. The Story of Our Country. Boston: Allyn \& Bacon, 1926.

West, Willis Mason. History of the American People. Boston: Allyn \& Bacon, 1918.

- Modern Progress. Boston: Allyn \& Bacon, 1920.

- World Progress. Boston: Allyn \& Bacon, 1922.

White, Henry Alexander. Beginner's History of the United States. New York: American Book Co., 1919.

Woodburn, James Albert, and Moran, Thomas Francis. Elementary American History and Government. New York: Longmans, Green \& Co., 1925.

- Finders and Founders of the Nere World. New York: Longmans, Green \& Co., 1925.

- Introduction to American History. New York: Longmans, Green \& Co., 1916.

BOOKS IN CIVICS, SOCIOLOGY, IN ECONOMIC AND POLITICAL PROBLEMS

Adams, Thomas Sewall, and Sumner, Helen L. Labor Problems. New York: Macmillan Co., 1917.

Ames, Edgar W., and Eldred, Arvie. Community Civics. New York: Macmillan Co., 1921.

Ashley, Roscoe Lewis. The Nerw Civics. New York: Macmillan Co., 1917.

Bailey, Carolyn Sherwin. What To Do for Uncle Sam. Chicago: A. Flanagan, 1925.

Beard, Charles A., and Beard, Mary Ritter. American Citizenship. New York: Macmillan Co., 1916.

Bennion, Mruton. Citizenship. Yonkers-on-Hudson, New York: World Book Co., 1925.

Berry, Margaret K., and Howe, Samuel B. Actual Democracy. New York: Prentice-Hall, Inc., 1923.

Binford, J. H., and Graff, E. U. The Young American Citizen. Richmond: Johnson Pub. Co., 1922.

Brooks, Eugene. Our Dual Government. Chicago: Rand, McNally \& Co., 1924.

Brooks, John Graham. An American Citizen. Boston: Houghton Mifflin Co., 1910 
Burch, Henry Reed. American Economic Life. New York: Macmillan Co., 1921.

Burch, Henry Reed, and Patterson, S. Howard. American Social Problems. New York: Macmillan Co., 1922.

- Problems of American Democracy. New York: Macmillan Co., 1922.

Bryant, Sara Cone. I Am an American. Boston: Houghton Mifflin Co., 1920.

Cabot, Ella Lyman; Andrews, Fannie Fern; Coe, Fanny E.; Hill, Mabel; and McSkinnon, Mary. A Course in Citizenship. Boston: Houghton Mifflin Co., 1914, 1924.

Davis, Sheldon E., and McClure, Clarence H. Our Government. Chicago: Laidlaw Bros., 1922.

Dawson, Edgar. Organized Self-Government. New York: Henry Holt \& Co., 1920.

Dole, Charles F. The Nere American Citizen. Boston; D. C. Heath \& Co., 1918.

Dunn, Arthur M. Community Civics for City Schools. Boston: D. C. Heath \& Co., 1921.

Dunn, Arthur W. Community Civics and Rural Life. Boston: D. C. Heath \& Co., 1920.

Ellwood, Charles A. Sociology and Modern Social Problems. New York: American Book Co., 1919, 1924.

Fairchild, Fred Rogers. Essentials of Economics. New York: American Book Co., 1923.

Fairchild, Henry Pratt. Elements of Social Science. New York: Macmillan Co., 1924.

- Immigration. New York: Macmillan Co., 1918.

Fauber, Arthur L. Principles of Economics. New York: Harcourt, Brace \& Co., 1923.

Finch, Charles Edgar. Everyday Civics. New York: American Book Co., 1921.

Forman, S. E. The American Democracy. New York: Century Co., 1920.

- The American Republic. New York: Century Co., 1911. - First Lessons in Civics. New York: American Book Co., 1898.

Fradenburgh, A. G. Elements of Economics. New York: Charles Scribner's Sons, 1921.

Garner, James W. Government in the United States. New York: American Book Co., 1913. 
Gettell, Raymond Garfield. The Constitution of the United States. Boston: Ginn \& Co., 1924.

Greenan, John T., and Meredith, Albert B. Everyday Problems of American Democracy. Boston: Houghton Mifflin Co., 1924.

Guitteau, William Backus. Preparing for Citizenship. Boston: Houghton Mifflin Co., 1918.

Hart, Josepr K. Social Life and Institutions. Yonkers-on-Hudson, New York: World Book Co., 1924.

Hayes, Bridget T. American Democracy. New York: Henry Holt \& Co., 1921.

Hepner, Walter R., and Hepner, Frances K. The Good Citizen. Boston: Houghton Mifflin Co., 1924.

Hill, Howard Copeland. Community Life and Civic Problems. Boston: Ginn \& Co., 1922.

Hill, Mabel. Lessons for Junior Citizens. Boston: Ginn \& Co., 1906.

Hughes, R. O. Economic Civics. Boston: Allyn \& Bacon, 1921.

-. New Community Civics. Boston: Allyn \& Bacon, 1924.

- A Text-Book in Citizenship. Boston: Allyn \& Bacon, 1923. James, James Alton, and Sanford, Albert Hart. Our Government

in State and Nation. New York: Charles Scribner's Sons, 1917. Jenks, Jeremiah Whipple, and Smith, Rufus Samuel. We and Our

Government. New York: American Viewpoint Society, 1922.

Lansing, Robert, and Jones, Gary M. Government, Its Origin, Growth and Form in the United States. New York: Silver, Burdett \& Co., 1911.

Lapp, John A. Our America, the Elements of Civics. Indianapolis: Bobbs-Merrill Co., 1917.

Levis, Elda Cannon. Citizenship. New York: Harcourt, Brace \& Co., 1923.

Long, Joseph R. Government and the People. New York: Charles Scribner's Sons, 1922.

Magruder, Frank Аввott. American Government with a Consideration of the Problems of Democracy. Boston: Allyn \& Bacon, 1921 and 1924.

Marshali, Leon C., and Lyon, Leverett S. Our Economic Organization. New York: Macmillan Co., 1922.

Mavity, Arthur Benton, and Mavity, Nancy Barr. Responsible Citizenship. Chicago: Benjamin H. Sanborn \& Co., 1923.

Mrller, Chester F. The March of Democracy. Boston: D. C. Heath \& Co., 1925. 
Morehouse, Frances, and Graham, Sybil Fleming. American Problems. Boston: Ginn \& Co., 1923.

Morgan, DeWrte S. Living and Working Together. New York: Charles Scribner's Sons, 1923.

Munro, William Bennetr. Current Problems in Citizenship. New York: Macmillan Co., 1924.

Munro, William Bennett, and Ozanne, Charles Eugene. Social

Civics. New York: Macmillan Co., 1925.

Parsons, Geoffrey. The Land of Fair Play. New York: Charles Scribner's Sons, 1919.

Reed, Thomas Harrison. Loyal Citizenship. Yonkers-on-Hudson, New York: World Book Co., 1922.

Rexford, Frank A., and Carson, Clara. The Constitution of Our Country. New York: American Book Co., 1924.

Riley, Eugene B. Economics for Secondary Schools. Boston: Houghton Miflin Co., 1924.

Shepherd, William G. The Boy's Own Book of Politics for Uncle Sam's Young Voters. New York: Macmillan Co., 1924.

Soutrworth, A. T. The Common Sense of the Constitution of the United States. Boston: Allyn \& Bacon, 1924.

Towne, Ezra Thayer. Social Problems. New York: Macmillan Co., 1924.

Turkington, Grace A. Community Civics, Life, Liberty and the Pursuit of Happiness in the United States. Boston: Ginn \& Co., 1924.

- My Country: A Textbook in Civics and Patriotism for Young Americans. Boston: Ginn \& Co., 1918.

Williamson, Thomas Ross. Problems in American Democracy. Boston: D. C. Heath \& Co., 1922.

Woodburn, James Albert, and Moran, Thomas Francis. The Citizen and the Republic. New York: Longmans, Green \& Co., 1918. Ziegler, Samuel H., and Jacquette, Helen. Our Community. Philadelphia: John C. Winston Co., 1918.

\section{TEXTBOOKS IN GEOGRAPHYY}

Allen, Nellie B. Africa, Australia and the Islands of the Pacific (Geographical and Industrial Studies). Boston: Ginn \& Co., 1924.

- Asia (Geographical and Industrial Studies). Boston: Ginn \& Co., 1916. 
. The New Europe (Geographical and Industrial Studies). Boston: Ginn \& Co., 1920.

- North America (Geographical and Industrial Studies). Boston: Ginn \& Co., 1922.

- South America (Geographical and Industrial Studies). Boston: Ginn \& Co., 1918.

- United States (Geographical and Industrial Studies). Boston: Ginn \& Co., 1925.

Barrows, Harlan H., and Parker, Edith Putnam. Geography: Journeys in Distant Lands. New York: Silver, Burdett \& Co., 1924.

- United States and Canada. New York: Silver, Burdett \& Co., 1925.

Beeby, Daniel J., and Beeby, Dorothea. How the World Grores Smaller. New York: Charles E. Merrill Co., 1924.

Bishop, Avard Longley, and Keller, Albert Galloway. Industry and Trade. Boston: Ginn \& Co., 1923.

Blaisdeli, Eтta Austin, and Blaisdell, Mary Frances. Child Life in Many Lands. A Third Reader. New York: Macmillan Co., 1900.

Brigham, Albert Perry, and McFarlane, Charles T. Essentials of Geography. First Book. New York: American Book Co., 1916.

- Essentials of Geography, Second Book. New York: American Book Co., 1920.

Carpenter, Frank G. Asia. Carpenter's Nere Geographical Reader. New York: American Book Co., 1923.

- North America. Carpenter's Nere Geographical Reader. New York: American Book Co., 1922.

- South America. Carpenter's Nero Geographical Reader. New York: American Book Co., 1921.

Chamberlain, James Franklin. How We Are Clothed. A Geographical Reader. New York: Macmillan Co., 1923.

- How We Are Fed. A Geographical Reader. New York: Macmillan Co., 1923.

- How We Are Sheltered. A Geographical Reader. New York: Macmillan Co., 1924.

- How We Travel: A Geographical Reader. New York: Macmillan Co., 1924.

Chance, Lulu Maude. Little Folks of Many Lands. Boston: Ginn \& Co., 1904. 
Clark, Rose B. Unit Studies in Geography. Yonkers-on-Hudson, New York: World Book Co., 1924.

Clark, Vinnie B. Europe. New York: Silver, Burdett \& Co., 1925. Fairgrieve, James, and Youna, Ernest. Children of Many Lands: Human Geography by Grades. Book One. New York: D. Appleton \& Co., 1923.

- Homes Far Away: Human Geography by Grades. Book Tro. New York: D. Appleton \& Co., 1923.

Huntington, Ellsworth. Asia. A Geography Reader. Chicago: Rand, McNally \& Co., 1923.

Knowlton, Philip A. First Lessons in Geography. New York: Macmillan Co., 1924.

Lefferts, Walter. Our Own United States. Philadelphia: J. B. Lippincott Co., 1925.

McMurry, Frank M., and Parkins, A. E. Advanced Geography. New York: Macmillan Co., 1923.

Mirick, George A. Home Life around the World. Boston: Houghton Mifflin Co., 1923.

Morris, Charles. Home Life in All Lands. Book One: How the World Lives. Philadelphia: J. B. Lippincott Co., 1907.

- Home Life in All Lands. Book Two: Manners and Customs of Uncivilized Peoples. Philadelphia: J. B. Lippincott Co., 1909. Packard, Leonard O., and Sinnott, Charles P. Nations as Neighbors. New York: Macmillan Co., 1925.

Perdue, H. Avis. Child Life in Other Lands. Chicago: Rand, McNally \& Co., 1918.

Pitkin, Walter B., and Hughes, Harold F. Seeing America. Book One: Farm and Field. New York: Macmillan Co., 1924.

Robinson, Edward Van Dyke. Commercial Geography. Chicago: Rand, McNally \& Co., 1920.

Salisbury, Rollin D.; Barrows, Harlan H.; and Tower, Walter S. The Elements of Geography. New York: Henry Holt \& Co., 1913.

Smith, J. Russell. Commerce and Industry. New York: Henry Holt \& Co., 1916.

- Human Geography Book One, Peoples and Countries. Philadelphia: John C. Winston Co., 1921.

- Book Troo, Regions and Trade. Philadelphia: John C. Winston Co., 1922.

. Industrial and Commercial Geography. New York: Henry Holt \& Co., 1925. 
TARr, Ralph S., and McMurry, Frank M. Nero Geographies: First Book. New York: Macmillan Co., 1920.

- Second Book. New York: Macmillan Co., 1920.

Whitbeck, R. H. High School Geography. New York: Macmillan Co., 1922.

\section{READERS}

Bailey, Carolyn Sherwin. Friendly Tales. Springfield, Massachusetts: Milton Bradley Co., 1923.

Baker, Franklin T.; Thorndike, Ashley H.; and Batchelder, Mildred. Everyday Classics: Second Reader. New York: Macmillan Co., 1922.

Baker, Franklin T., and Thorndike, Ashley H. Everyday Classics: Third Reader. New York: Macmillan Co., 1917.

- Everyday Classics: Fourth Reader. New York: Macmillan Co., 1917.

- Everyday Classics: Fifth Reader. New York: Macmillan Co., 1917.

- Everyday Classics: Sixth Reader. New York: Macmillan Co., 1917.

- Everyday Classics: Seventh Reader. New York: Macmillan Co., 1918.

- Everyday Classics: Eighth Reader. New York: Macmillan Co., 1918.

Baldwin, James. The Story of Liberty. New York: American Book Co., 1910.

Browne, Hetty S.; Withers, Sarah; and Tate, W. K. The Child's World: Second Reader. Richmond: B. F. Johnson Pub. Co., 1920.

- Third Reader. Richmond: B. F. Johnson Pub. Co., 1920.

Coe, Ida, and Specht, Louise. Easy Steps in Reading. New York: American Pub. Co., 1923.

Coe, Ida, and Dillon, Alice Christie. Story Hour Readers: Revised Primer. New York: American Book Co., 1923.

. Story Hour Readers: Revised Book Two. New York: American Book Co., 1923.

Cowles, Julia Darrow. Plays and Poems. Book One. Chicago: Row, Peterson \& Co., 1921.

Davidson, Isabel, and Anderson, Charles J. The Lincoln Readers: Third Reader. New York: Laurel Book Co., 1922.

- The Lincoln Readers: Fourth Reader. New York: Laurel Book Co., 1922. 
Davidson, Isabel, and Anderson, Charles J. The Lincoln Readers:

Sixth Reader. New York: Laurel Book Co., 1923.

Demarest, A. J., and Van Sickle, William M. Nere Education

Readers. 4 Vols: New York: American Book Co., 1900.

- New Education Readers Book One. New York: American Book Co., 1918.

- New Education Readers Book Troo. New York: American Book Co., 1900.

- New Education Readers Book Three. New York: American Book Co., 1901.

- New Education Readers Book Four. New York: American Book Co., 1901.

Dressex, Herman; Robbins, MaY; and Graff, Ellis U. The Nerw Barnes Readers: First Year, Second Half. New York: A. S. Barnes Co., 1916.

- The New Barnes Readers, Book Tro. New York: A. S. Barnes Co., 1917.

- The Nere Barnes Readers, Book Four. Chicago: Laidlaw Bros., 1921.

- The New Barnes Readers. New York: A. S. Barnes Co., 1920.

Dunn, Fannie Wyche; Baker, Franklin T.; and Thorndike, AshLEY H. Everyday Classics: First Reader. New York: Macmillan Co., 1922.

Dyer, Franklin B., and Brady, Mary J. The Merrill Readers: Primer. New York: Charles E. Merrill Co., 1915.

- The Merrill Readers: First Reader. New York: Charles E. Merrill Co., 1915.

- The Merrill Readers: Second Reader. New York: Charles E. Merrill Co., 1915.

- The Merrill Readers: Fourth Reader. New York: Charles E. Merrill Co., 1916.

- The Merrill Readers: Fifth Reader. New York: Charles E. Merrill Co., 1916.

- The Merrill Readers: Sixth Reader. New York: Charles E. Merrill Co., 1916.

Elson, William H., and Burris, Mary H. Child Library Readers. Book Five, "The Elson Extension Series." Chicago: Scott, Foresman \& Co., 1923.

Elson, William H., and Runkel, Lura E. The Elson Readers: Primer. Chicago: Scott, Foresman \& Co., 1920. 
The Elson Readers: Book Tro. Chicago: Scott, Foresman \& Co., 1920.

Elson, William H. The Elson Readers: Book Three. Chicago: Scott, Foresman \& Co., 1920.

Elson, William H., and Keck, Christine M. The Elson Readers: Book Five. Chicago: Scott, Foresman \& Co., 1920.

- The Elson Readers: Book Seven. Chicago: Scott, Foresman \& Co., 1921.

Ettinger, William Louis; Shimer, Edgar Dubs; O'Regan, James J. The Progressive Road to Silent Reading: Fourth Year. New York: Silver, Burdett \& Co., 1922.

Fassett, James H. The Beacon Fourth Reader. Boston: Ginn \& Co., 1917.

Field, Walter Taylor. The Field First Reader. Boston: Ginn \& Co., 1921.

Fryer, Jane Eayre. Our Home and Personal Duty. Young American Readers. Philadelphia: John C. Winston Co., 1918.

- Community Interest and Public Spirit. Young American Readers. Philadelphia: John C. Winston Co., 1919.

- Our Town and Civic Duty. Young American Readers. Philadelphia: John C. Winston Co., 1920.

Gordon, Emma K., and Stockard, Marietta. Second Reader. Boston: D. C. Heath \& Co., 1918.

Gondon, Емma K. Third Reader. Boston: D. C. Heath \& Co., 1918. - Fourth Reader. Boston: D. C. Heath \& Co., 1918.

—. Fifth Reader. Boston: D. C. Heath \& Co., 1918.

Haliburton, M. W. The Haliburton Primer. Boston: D. C. Heath \& Co., 1919.

- The Haliburton First Reader. Boston: D. C. Heath \& Co., 1919.

. The Haliburton Second Reader. Boston: D. C. Heath \& Co., 1919.

. The Haliburton Third Reader. Boston: D. C. Heath \& Co., 1919.

. The Haliburton Fourth Reader. Boston: D. C. Heath \& Co., 1913. 1916.

Hartweld, E. C. Story Hour Readings Fourth Year. New York: American Book Co., 1921. 
Hartwell, E. C. Story Hour Readings Fifth Year. New York: American Book Co, 1921.

- Story Hour Readings Sixth Year. New York: American Book Co., 1921.

- Story Hour Readings Seventh Year. New York: American Book Co., 1921.

- Story Hour Readings Eighth Year. New York: American Book Co., 1921.

The Heath Readers Primer. Boston: D. C. Heath \& Co., 1903.

The Heath Readers Second Reader. Boston: D. C. Heath \& Co., 1903.

The Heath Readers Fourth Reader. Boston: D. C. Heath \& Co., 1903.

The Heath Readers Fifth Reader. Boston: D. C. Heath \& Co., 1903.

The Heath Readers Sixth Reader. Boston: D. C. Heath \& Co., - 1904.

Hervey, Walter L., and Hix, Melvin. New Primer: The Horace Mann Readers. New York: Longmans, Green \& Co., 1922.

- New Primer and New Daily Lesson Plans. New York: Longmans, Green \& Co., 1922.

- New First Reader and Nerw Daily Lesson Plans. New York: Longmans, Green \& Co., 1922.

- The Horace Mann Readers: Introductory Fourth Reader. New York: Longmans, Green \& Co., 1917.

- The Horace Mann Readers Fifth Reader. New York: Longmans, Green \& Co., 1914.

- The Horace Mann Readers Sixth Reader. New York: Longmans, Green \& Co., 1915.

- The Horace Mann Readers Seventh Reader. New York: Longmans, Green \& Co., 1918.

- The Horace Mann Readers Eighth Reader. New York: Longmans, Green \& Co., 1918.

Horn, Ernest; Cutright, Prudence; and Horn, Madeline DarRAUGH. The Learn To Study Readers: First Lessons in Learning To Study. Boston: Ginn \& Co., 1926.

Horn, Ernest, and McBroom, Maude. Manual of Directions for the Learn To Study Readers, Book II. Boston: Ginn \& Co., 1924.

Horn, Ernest, and Moscrip, Ruth M. The Learn To Study Readers. Book IV, Grade Five. Boston: Ginn \& Co., 1926. 
Lewis, William D.; Rowland, Albert Lindsay; and Gehres, Ethel

H. Maltby. The Silent Readers: First Reader. Philadelphia: John C. Winston Co., 1924.

- The Silent Readers First Reader Manual. Philadelphia: John C. Winston Co., 1924.

- The Silent Readers Second Reader. Philadelphia: John C. Winston Co., 1924.

- The Silent Readers Third Reader. Philadelphia: John C. Winston Co., 1923.

- The Silent Readers Fourth Reader. Philadelphia: John C. Winston Co., 1920.

- The Silent Readers Fifth Reader. Philadelphia: John C. Winston Co., 1920.

- The Silent Readers Sixth Reader. Philadelphia: John C. Winston Co., 1920.

Lewis, William D., and Rowland, Albert Lindsay. The Silent Readers Seventh Reader. Philadelphia: John C. Winston Co., 1920.

Lewis, William D.; Rowland, Arbert Lindsay; and Gehres, Ether H. Maltby. The Silent Readers Eighth Reader. Philadelphia: John C. Winston Co., 1920.

Lyman, Rollo L., and Hilu, Howard C. Literature and Living, Book One. New York: Charles Scribner's Sons, 1925.

- Literature and Living, Book Two. New York: Charles Scribner's Sons, 1925.

- Literature and Living, Book Three. New York: Charles Scribner's Sons, 1925.

McManus, Hannah T., and Haren, John H. The Natural Method Readers: A Primer. New York: Charles Scribner's Sons, 1914.

- The Natural Method Readers: A First Reader. New York: Charles Scribner's Sons, 1914.

- The Natural Method Readers: A Second Reader. New York: Charles Scribner's Sons, 1915.

- The Natural Method Readers: A Third Reader. New York: Charles Scribner's Sons, 1916.

McManus, Hannah T. The Natural Method Readers: A Fifth Reader. New York: Charles Scribner's Sons, 1918. Miller, Sophia A., and Hughes, James L. Midway Readers, Books One, Two and Three. Chicago: Laidlaw Bros., 1922. 
Nicholson, Meredith, ed. Heart of America Readers: A Primer, by Hannah T. McManus and John H. HaAren. New York: Charles Scribner's Sons, 1919.

- Heart of America Readers: A First Reader. New York: Charles Scribner's Sons, 1919.

- Heart of America Readers: A Second Reader. New York:

Charles Scribner's Sons, 1919.

Nicholson, Meredith; Howe, Will D.; and Pritchard, Mrron T. Heart of America Readers: A Third Reader. New York: Charles Scribner's Sons, 1919.

- Heart of America Readers: A Fourth Reader. New York: Charles Scribner's Sons, 1919.

Peters, Merian Shaw. The Peters and Brumbaugh Method Readers, Book Four. Philadelphia: Christopher Sower Co., 1919.

Robbins, May; Dressei, Herman; and Graff, Ellis U. The Nere Barnes Readers: First Year First Half. New York: A. S. Barnes Co., 1916.

Searson, J. W.; Martin, George E.; and Tinley, Lucy Wildiams. Studies in Reading: Additional Primer. Lincoln: University Pub. Co., 1922.

- Studies in Reading: First Grade. Lincoln: University Pub. Co., 1920.

—. Studies in Reading: Second Grade. Lincoln: University Pub. Co., 1920.

Searson, J. W., and Martin, George E. Studies in Reading: Third Grade. Lincoln: University Pub. Co., 1920.

Smith, Carrie J. The Easy Road to Reading: Third Reader. Chicago: Lyons \& Carnahan, 1917.

Withers, Sarah; Browne, Hetty S.; and Tate, W. K. The Child's World: Primer. Richmond, Virginia: B. F. Johnson Pub. Co., 1920.

—. The Child's World: First Reader. Richmond: B. F. Johnson Pub. Co., 1920.

\section{FOREIGN LANGUAGE AND MUSIC FRENCH TEXTBOOKS}

Bierman, Henry, and Frank, Colman Dudley. A Conversational French Reader for Beginners. Boston: Allyn \& Bacon, 1915. Chardenal, C. A. Complete French Course. Boston: Allyn \& Bacon, 1923. 
Halevy, Ludovic. L'Abbé Constantin. New York: Henry Holt \& Co., 1894.

Labiche, M. M. Eugìne, and Martin, Edouard. La poudre aux yeux. New York: Henry Holt \& Co., 1918.

- Le voyage de Monsieur Perrichon. New York: Henry Holt \& Co., 1905.

Lavisse, Ernest. Histoire de France. Boston: D. C. Heath \& Co., 1919.

Matrêt, Jeanne. La tâche du petit Pierre. New York: American Book Co., 1896.

Méras, Albert A., and Méras, B. Le premier livre. New York: American Book Co., 1915.

Méras, Albert A., and Roth, Suzanne. Petits contes de France. New York: American Book Co., 1916.

De Monvert, Adolphe. La belle France. Boston: Allyn \& Bacon, 1916.

\section{ITALIAN TEXTBOOKS}

De Amicis, Edmondo. Cuore. Oscar Kunns, ed. New York: Henry Holt \& Co., 1923.

Van Horne, John. Il Risorgimento. Ernest Hatch Wilkins, ed. Chicago: University of Chicago Press, 1922.

Wilkins, Ernest Hatch, and Marinoni, Antonio. L'Italia. Chicago: University of Chicago Press, 1920.

Wilkins, Lawrence A., and Santelli, Catharine R. Beginners' Italian Reader. New York: D. C. Heath \& Co., 1925.

SPANISH TEXTBOOKS

Dorado, Carolina Marcial. Primeras lecturas en Español. Boston: Ginn \& Co., 1920.

Hills, E. C., and Ford, J. D. M. First Spanish Course. Boston: D. C. Heath \& Co., 1917.

Ibañez, Blasco. Vistas Sudamericanus (Dorado). Boston: Ginn \& Co., 1920.

Nelson, Ernesto. The Spanish American Reader. Boston: D. C. Heath \& Co., 1916.

Pèrez Escrich, Enrique. Fortuna. Boston: Ginn \& Co., 1907. Roessler, Erwin W., and Remy, Alfred. First Spanish Reader.

New York: American Book Co., 1916.

Valera, Juan. El pázaro verde. Boston: Allyn \& Bacon, 1918. 
MUSIC

Alexander, Birdie, ed. Songs We Like To Sing. New York: Silver, Burdett \& Co., 1912.

Armitage, M. Teresa. Junior Laurel Songs. Boston: C. C. Birchard \& Co., 1917.

- Senior Laurel Songs. Boston: C. C. Birchard \& Co., 1926.

- The Laurel Unison Book. Boston: C. C. Birchard \& Co., 1917.

Damrosch, Walter; Gartlan, George H.; and Gehrkens, Karl W., EDs. Universal School Music Series: Primer (1923). New York: Hinds, Hayden \& Eldredge.

- Universal School Music Series, Book One. New York: Hinds, Hayden \& Eldredge, 1923.

- Universal School Music Series, Book Two. New York: Hinds, Hayden \& Eldredge, 1923.

- Universal School Music Series, Book Three. New York: Hinds, Hayden \& Eldredge, 1923.

- Universal School Music Series, Book Four. New York: Hinds, Hayden \& Eldredge, 1924.

Dann, Hollis. Music Course, First Year Music. New York: American Book Co., 1914.

- Music Course, Second Year Music. New York: American Book Co., 1915.

- Music Course, Third Year Music. New York: American Book Co., 1915.

- Music Course, Fourth Year Music. New York: American Book Co., 1916.

- Music Course, Fifth Year Music. New York: American Book Co., 1916.

- Music Course, Sixth Year Music. New York: American Book Co., 1917.

- Music Course, Junior Music. New York: American Book Co., 1917.

Earhart, Will. Art Songs for High Schools. New York: American Book Co., 1910.

Farnsworth, Charles H. Grammar School Songs. New York: Charles Scribner's Sons, 1917.

Foresman, Robert. Book of Songs: First Book of Songs. New York: American Book Co., 1925.

- Book of Songs, Second Book of Songs. New York: American Book Co., 1925. 
- Book of Songs, Third Book of Songs. New York: American Book Co., 1925.

- Book of Songs, Fourth Book of Songs. New York: Ameri'can Book Co., 1925.

- Book of Songs, Fifth Book of Songs. New York: American Book Co., 1926.

Giddings, Thaddeus P.; Earhart, Will; Baldwin, Ralph L.; and Newton, Elbridge W. Music Education Series: Songs of Childhood. Boston: Ginn \& Co., 1923.

- Music Education Series, Introductory Music. Boston: Ginn \& Co., 1923.

- Music Education Series, Juvenile Music. Boston: Ginn \& Co., 1925.

- Music Education Series, Elementary Music. Boston: Ginn \& Co., 1924.

- Music Education Series, Intermediate Music. Boston: Ginn \& Co., 1924.

- Music Education Series, Three Part Music. Boston: Ginn \& Co., 1925.

- Music Education Series, Junior Music. Boston: Ginn \& Co., 1924.

Giddings, Thaddeus P., and Newton, Elbridge W. The Junior Song and Chorus Book. Boston: Ginn \& Co., 1925.

Johnstone, Arthur Edward, and Loomis, Harvey Worthington. Lyric Music Series: Primer. Chicago: Scott, Foresman \& Co., 1913.

- Lyric Music Series: First Reader. Chicago: Scott, Foresman \& Co., 1912.

- Lyric Music Series: Second Reader. Chicago: Scott, Foresman \& Co., 1912.

- Lyric Music Series: Third Reader. Chicago: Scott, Foresman \& Co., 1913.

Livermore, Charles Herbert. The American Song Book. Boston: Ginn \& Co., 1917.

McConathy, Osbourne. The School Song Book. Boston: C. C. Birchard \& Co., 1916.

NeColuins, J. E. Glee and Chorus Book. New York: American Book Co., 1911.

Parker, Horatio; McConathy, Osbourne; Birge, Edward Bailey; and Mressner, W. Отто. The Progressive Music Series, Book One. New York: Silver, Burdett \& Co., 1920. 
Parker, Horatio; McConathy, Osbourne; Birge, Edward Bailey; and Miessner, W. Отто. The Progressive Music Series, Book Troo. New York: Silver, Burdett \& Co., 1920.

- The Progressive Music Series, Book Three. New York: Silver, Burdett \& Co., 1920.

- The Progressive Music Series, Book Four. New York: Silver, Burdett \& Co., 1920.

Smith, Eleanor. Music Course: Primer. New York: American Book Co., 1911.

- Music Course, Book One. New York: American Book Co., 1908.

- Music Course, Book Tro. New York: American Book Co., 1908.

- Music Course, Book Three. New York: American Book Co., 1908.

- Music Course, Book Four. New York: American Book Co., 1908.

Twice 55 Community Songs, No. 1, The Brown Book. Boston: C. C. Birchard \& Co., 1919.

Twice 55 Community Songs, No. 2, The Green Book. Boston: C. C. Birchard \& Co., 1923.

White, William Alfred, ed. Lake High School Song Book. Chicago: Scott, Foresman \& Co., 1916.

COURSES OF STUDY PREPARED BY STATE DEPARTMENTS

OF INSTRUCTION

General Course of Study for Arizona Schools. State Board of Education, 1923.

Course of Study for High Schools, Part III, Social Science Studies [Arkansas]. State Board of Education, 1925.

Colorado State Course of Study in Education. State Superintendent of Public Instruction, 1922.

A Manual of the Social Studies for Secondary Schools [Connecticut]. Hartford: State Board of Education, 1924.

A Course of Study in the Social Studies [Connecticut]. Hartford: State Board of Education, 1924.

A Syllabus of a Proposed Course of Study of the History of Delaware for the High Schools of Delaware.

Course of Study for the Elementary Schools of Florida. Tallahassee:

Department of Public Instruction, 1924.

Manual for Georgia Teachers. State Department of Education, 1925. 
Manual and Courses of Study for the High Schools of Idaho. State Board of Education, 1923.

Burris, Benjamin J. History and Social Sciences, State of Indiana, Department of Public Instruction, Bulletin No. 65-D. Indianapolis, Indiana, 1923.

Francis, May E. An Analysis of the Constitution of the United States and the Constitution of Iorva. Des Moines, Iowa: Published by the State of Iowa, 1924.

- A Syllabus for the Study of Civics in the High Schools of Iowa. Des Moines, Iowa: Published by the State of Iowa, 1923.

McClenahan, P. E. Course in American Citizenship in the Grades. For the Grammar Grades, VII, VIII. Des Moines, Iowa: Published by the State of Iowa, 1921.

- For the Intermediate Grades, IV, V, VI. Des Moines, Iowa: Published by the State of Iowa, 1921.

- For the Primary Grades, I, II, III. Des Moines, Iowa: Published by the State of Iowa, 1921.

Harris, T. H. State Course of Study for Elementary Schools of Louisiana. Department of Education, 1924. Baton Rouge, Louisiana: Ramires-Jones Printing Co.

A Suggested Plan for the Study of the Constitution of the United States in Elementary and Junior and Senior High Schools. Commonwealth of Massachusetts; Bulletin of the Department of Education (1924), No. 4.

The High School Curriculum and Syllabi of High School Subjects [Minnesota]. Bulletin Number 3-C. Social Studies, Introduction to Social Science. St. Paul: Department of Education, 1925.

State of Minnesota, Department of Education. Curriculum for Elementary Schools. State Department of Education, January, 1923.

State of Mississippi Department of Education. Bulletin No. 29 (1924), High Schools (abridged edition), by G. M. Ivy. Issued by W. F. Bond, State Superintendent of Education.

Suggested Courses of Study for Missouri High Schools in American Citizenship. Charles A. Lee, State Superintendent of Public Schools.

State Course of Study for the Elementary Schools in the State of Missouri. Charles A. Lee, State Superintendent of Public Schools, 1924. 
State Course of Study for Montana City Elementary Schools (1924). Prepared by State Department of Public Instruction, Helena, Montana.

State of Nevada, Supplement to the 1922 Elementary Courses of Study and the 1923 Text Book Adoptions. Carson City: State Printing Office, 1923.

Program of Studies Recommended for the Public Schools of New Hampshire Grades VII and VIII. State Board of Education. 4th ed., 1924.

State of New Jersey Department of Public Instruction, Trenton. Syllabus of Social Studies for Secondary Schools, February, 1925.

New Mexico Common Schools Course of Study (1923).

Courses of Study for the High Schools of North Carolina. Educational Publication No. 79. Raleigh, North Carolina: Published by the State Superintendent of Public Instruction.

State of Oklahoma Department of Public Instruction. Course of Study for the Common Schools. Grades 1-8 (1924). Bulletin No. 101. Oklahoma City.

Course of Study for the High Schools of Oregon. (1925-27). Salem, Oregon: Department of Education, 1925.

State of Pennsyluania. Courses in the Social Studies. Harrisburg, 1926.

Carroli, Charles. Outline of Government in Rhode Island for Use in Schools. Public Education Service, State of Rhode Island, 1924.

High School Manual for South Dakota. Pierre: J. Fred Olander Co., 1922.

Department of Education, State of Tennessee. High School Manual (1925). For county high schools.

Texas High School Course of Study. No. 196. State Department of Education, 1925.

Manual and Course of Study Elementary Grades Public Schools of Texas (1924-25). Bulletin 184. Department of Education.

Utah Course of Study for the Secondary Schools: The Junior High School. Salt Lake City: State Department of Public Instruction, 1923.

- The Senior High School. Salt Lake City: State Department of Public Instruction, 1923. 
High Schools of Vermont Manual and Courses of Study. Issued by State Board of Education. Whole Bulletin No. 1 (1923).

State Courses of Study High Schools of Virginia, History and Social Science. Bulletin State Board of Education, Supplement No. 2. Richmond, 1925.

A Manual for the High Schools of Wisconsin. Madison, Wisconsin: Issued by John Callahan, 1924.

COURSES OF STUDY IN CITY SCHOOL SYSTEMS

Department of Education, City of Baltimore. The Social Studies Course of Study for Senior and Junior High Schools. Baltimore, 1925 .

Boston Public Schools. Course in Citizenship through Character Development Grades I to VIII. Boston, 1924.

Clark, M. G. Progress and Patriotism. Bloomington, Illinois: Public School Pub. Co., 1923.

Denver. Course of Study Monograph, Grades Seven, Eight and Nine. No. 3. Denver: Public Schools, 1924.

- Course of Study Monograph, Senior High School. No. 19. Denver: Public Schools, 1926.

- Course of Study Monograph, Elementary School. No. 20. Denver: Public Schools, 1926.

Department of Superintendence. Fourth Yearbook. The Nation at Work on Its Public School Curriculum. Washington, D.C.: Department of Superintendence, 1926.

Detroit. Courses of Study, Social Science Grades 1-6. Detroit: Board of Education, 1927.

Indianapolis Public Schools. Course of Study in American Citizenship. Indianapolis, 1922.

New Yonк. Syllabus for High Schools and Junior High Schools: First Year Civics. New York: Board of Education, 1923.

Character Education in High Schools. New York: Board of Education, 1924.

Омана. Public School Course of Study in History Elementary Grades. Omaha: Board of Education, 1923.

St. Louis. Social Studies Curriculum Bulletin, Nos. 6, 13, 25, 26, 27, 28. St. Louis: Board of Education, 1926. 
Trenton, New Jersey. History, Elementary Course of Study. Trenton: Board of Education, 1922.

- History, Secondary Course of Study, Grades 7 and 8. Trenton: Board of Education, 1924.

- American History, Secondary Course of Study. Trenton: Board of Education, 1923.

- Early European History, Secondary Course of Study. Trenton: Board of Education, 1924.

- Modern European History Course of Study, Grade 11. Trenton: Board of Education, 1924. 


\section{INDEX}





\section{INDEX}

Acts of Trade, 15

Adams, John Quincy, 120, 169, 204

Adams, Samuel, 117, 154

Alabama Claims, 43

Alamo, story of, 71

Alaska, 77

Allen, Ethan, 118, 204-5

Allen, N. B., South America, 190

Alsace-Lorraine, 60, 61, 62; in French textbooks, 223-24

Altschul, Charles, study of American Revolution in fifty-three textbooks, 22, 29-30

“America," song, 217

America. See United States

"America the Beautiful," 217

“America Education Week," 248

"America to Great Britain," 201

“America for Me," 217

America in music textbooks: glory of service to country, 218-19; homage to the flag, 220; land of freedom and peace, 217-18; patriotism, 221; war extolled, 220

American colonies: navigation laws, 13; protection of colonists by England, 12; racial elements in, 13; transportation of criminals to, 13. See American Revolution

“American's Creed," 210

American flag: in courses of study in citizenship, 244-45; in courses of study in history, 247; in music, 221; pledge of citizenship, 171, 210; in the readers, 207-11; as a symbol, 114-16, 170-71, 247; valor and achievement of our heroes in order to preserve the, 169

“American Flag, The," 207

American Legion, 19, 115, 248-49; textbook sponsored by, 8

American Revolution, 13-35; attitude of colonists toward allies, 50; British and Colonial troops compared, 25, $27 \mathrm{ff}$.; effect of description of, 24, 27-28; effect on popular government, 23; employment of German mercenaries in, 55; French alliance, 49; study by Altschul, 29 ff.
American School Citizenship League, Course with Type Studies, 41

American seamen, impressment of, 33 . See War of 1812

Americans, characteristics of: in arts and science, 108-9; in education, 109-10; feeling of superiority over other nations, 124-25; loyalty to heroic characters, 117-21; sense of nationality, 116-17. See United States

Ames and Eldred, Community Civics, 141, $142,144,145,147,148,149,152,169$, 170,171

Andros episode, 10

Anglo-American relations: Alabama claims, 42; arbitration of claims, $42 \mathrm{ff}$.; during Civil War, 42; increased friendship for the United States, 46; regarding Monroe Doctrine, 42; Oregon dispute, 41 ; portrayal of, in textbooks during American Revolution and present day, 46-47; seal fisheries controversy, 43; during Spanish-American War, 46; Venezuelan boundary dispute, 44; Webster-Ashburton Treaty, 42; during World War, 46

"Anvil Chorus," 221

Arbitration, Anglo-American, 42 ff.

Argentine, 75

Argonne, battle of, 66

Arizona, General Course of Study, 242, 244,246

Arkansas, Course of Study for High Schools, 248

Armenians, as immigrants to America, 162

"Army of Peace, The," 212

Arnold, Benedict, 119

Articles of Confederation, 103

Ashley, R. L., The New Civics, 143, 145, $147,148,152,165,166,169,170,171$

Asiatics: early progress of, 181-83; trade with the United States, 186-87

Atkinson, A. M., European Beginnings of American History, 86

Austria, attitude toward in European history textbooks, 131-33

Bagley, W. G. C., character of treatment of American Revolution, 15 
Bailey, C. S., What To Do for Uncle Sam, 148,170

Baker and Thorndike, Everyday Classics: Second, 211; Third, 205, 210; Fifth, 204, 212; Sixth, 204, 205, 212; Seventh, $196,203,205,207,212$

Baldwin, James, The Story of Liberty, 9, $52,198,201 ; 202,204,206,207,213$

Balfour: speech of, 201-2; visit of, to United States, 53

Baltimore, Course for Senior and Junior High Schools, 249

Barker, Webb, and Dodd, The Growth of a Nation, 6, 19, 21

Barnes, Everett, American History for Grammar Grades, 12, 16, 19, 21, 26, 34, $38,44,49,52,59,62,81,82,86,88,97$, 110, 112, 118, 119, 121; Short American History for Grades, 13, 31, 36, 40, 43, 52 , $56,69,81,82,88,97,99,101,105,121$

Barry, John, 118

"Battle Cry of Freedom," the, 217

"Battle Hymn of the Republic," 217

Beard and Bagley, First Book in American History, 101, 105, 108, 118; The History of the American People, 15, 19, 21, 26, $32,34,42,49,51,56,58,59,63,88,96$, $98,99,104,118$

Beard, C. A., and Mary R.: American Citizenship, 141, 142, 144, 145, 147, 148; character of treatment of American Revolution, 15; History of the United States, 8, 16, 19, 21, 24, 32, 34, 41, 42, $46,50,53,55,59,72,74,78,81,82,90$, $91,93,95,96,98,99,101,105,112,113$, 119

Beecher, Henry Ward, 208

Belgium: characteristics of people, 180; invasion of, 63-65, 179; plan of annexation of, by Germany, 61

Bennett, Henry Holcomb, 207

Bennion, Milton, Citizenship, 142, 143

Berlin-to-Bagdad Railway, 61

Berry and Howe, Actual Democracy, 141, $142,143,144,147,152,153,154,155$, $156,157,162,163,168$

Bill of Rights, 143, 154. See American Political Theories

Binford and Graff, The Young American Citizen, 141, 145, 148, 168, 171

Bismarck, 57

Blaisdell and Blaisdell, Child Life in Many Lands, 175, 177

Bolsheviki, 78-79, 134, 179

Boone, Daniel, 120
Boston, course of study, in, 249

"Boston Massacre," 204

Bourne and Benton: American History, 7, $19,21,23,34,38,40,41,42,46,49,52$, $59,69,76,77,81,84,90,101,104,107$, $117,118,121$; character of treatment of American Revolution, 15; History of the United States, 12, 15, 16, 21, 25, 41, $50,57,62,63,70,96,99,118,119$

"Boy, the Bees and the British, The," 202

Braddock, General, 11-13

Brazil, 75, trade with the United States, 186

Breed's Hill, 25

Brest-Litovsk, Treaty of, 78

Brigham and McFarlane, Essentials of Geography: First Book, 179, 181, 184, 190

Bright, John, 43

Brooks, Eugene, Our Dual Government, $140,141,145,146,148,163,165,168$, 169,170

Brown, John, 120

Bryant, S. C., I Am an American, 145, $148,153,154,157,159,168,169,170$, 171

Bryant, William Cullen, 204

Bryce, Viscount, 142

Burch, H. R., American Economic Life, $157,162,163$

Burch and Patterson, Problems of American Democracy, 145, 146, 147, 149, 151, $152,155,157,160,162,163,164,166,168$

Burke, Edmund, 203

Burnham, Smith, The Making of Our Country, 3, 4, 5, 11, 12, 15, 19, 21, 23, $25,28,32,34,38,44,48,50,52,55,56$, $58,59,62,82,88,89,91,95,97,104$, $107,112,113,118,121$

Cabot, E. L., and others, $A$ Course in Citizenship, 145, 146, 148, 159, 165

Calhoun, John C., 34, 120

Canada: desire for, by United States, 33-35; relations with the United States, 41,68

"Capture of Ticonderoga, The," 204

Caribbean Sea, American interest in, 98, 99. See Foreign policy of the United States; Protectorates; Monroe Doctrine

Carpenter, F. G., Asia, 177, 181, 183, 186, 187, 189; Europe, 176, 178, 179, 180, 181, 185, 189; North America, 189, 190; South America, 181, 183, 186 
“Catching a Spy," 197-98

Catholics. See Irish

Channing, Edward: character of treatment of American Revolution, 15;A Students' History of the United States, $3,4,7,8,15,24,34,36,41,42,43,52$, $59,69,84,90,92,100,104,119,121$; Elements of United States History, 11, $12,26,31,35,52,56,96,104,118,119$

Chardenal, Complete French Course, treatment of attitude of Alsatians toward Germany and France, 223, 224

Charlemagne, as a heroic figure in French textbooks, 222

Chesapeake and Leopard Affair, 37; attitudes engendered by discussion of, 37

Cheyney, W. Walker, Education for International Goodwill, 251

Child Library Readers, Book Five, 202, 212

Child's World, The, Second Reader, 211

Chile, 75, 183

Chinese: characteristics of, 175, 182-83; early progress of, 182

Chinese-American relations: in Boxer Rebellion, 82; commerce with the United States, 187; friendly attitude of the United States, 183; Open Door Policy, 82; restriction of Chinese in the United States, 81-82, 160-61

Citizen, the, definition of, 139

Citizenship: courses in, 243-46; blessings of, $140 \mathrm{ff}$.; exercise of the suffrage, 14446; obedience to law, 114, 148, 150; office holding, 146-47; payment of taxes, 149; preservation of, by organized government, 140-44; responsibilities of, 139 ff.; rights of, $142 \mathrm{ff}$.; service to the country in time of war, 14950,213 ; service on juries, 148-49; textbooks in, 141-77

"Civic Creed for the Boys and Girls of the Great Republic," 210

Civil service reform, 105, 146

Civil War: English attitude toward, 42; friendly attitude of Russia, in, 77; French attitude toward, 53; negro in, 163

Clark, George Rogers, 169

Clark, M. G., Progress and Patriotism, 250,251

Clay, Henry, 34, 120, 169

Clayton-Bulwer Treaty, 45

Cleveland, course of study, 250

Cleveland, Grover, 120

Cobden, Richard, 43
Coe, F. E., Founders of Our Country, 9, 119; Heroes of Everyday Life, 251

Colombia, 95-96

Colonial period, characteristics of, 10

Colonists, attitude toward English laws, 14-15; attitude toward Napoleon, 52; character of, 15; political beliefs of, 15; smuggling, 15. See American Revolution; England

Colorado: course of study, 247; Denver schools, 249, 250

"Columbia, the Gem of the Ocean," 217

Columbus, Christopher, 117

Committee on World Friendship, 252

"Concord Hymn," 204

Confederacy, English attitude toward, 42

Connecticut, course in citizenship, 244

Constitution, the, 103, 104-5; as the fundamental law of the land, 141; ideals expressed in, 142-43; preamble of, 144, $147,169,202$

Coolidge, Susan, 212

Course with Type Studies, 41

Course of study in city school systems, 249-52

Courses of study, 242-53

Courses of study prepared by state departments of instruction: citizenship, 243-46; geography, 242-43; history, 246-49

"Creed of Americanism, A," 210

Crevecour, quoted, 107-8

Cuba and the United States, 7, 93, 166. See Spanish-American War; Dependencies of the United States

Curtis, George W., 204

Czechoslovaks: as immigrants to America, 162; trade with America, 185

Daffan, Katie, History of the United States, 7, 20, 39, 42, 103, 113, 119, 120, 254

Daily Iowan, 115

Daily Service, 212

Danes, characteristics of, 180

Danish Islands, 98

Davidson and Anderson, Lincoln Readers: Third, 206; Fourth, 196, 203, 205; Sixth, 211

Davis, Jefferson, 120

Davis and McClure, Our Government, 141, $142,145,147,149,154,170$

Dawson, Edgar, Organized Self-Government, 148, 165 
De Amicis, Cuore, 225

Declaration of Independence, 103, 104, $105,143,204$

Deering High School, Portland, Maine, course of study in, 251

De Kalb, 53, 56

Demarest and Van Sickle, New Education Readers: Book Two, 205, 210

Denver, course of study, in, 249

Department of Superintendence, Year Book, 250

Dependencies of the United States, 93-99

Dewey, Admiral, 58, 120

Dickinson, John, 119

Dickson, Thomas J., Critique on American School Histories, 123, 124

Diedrich, von, 58

Dole, Charles F., 212; The New American Citizen, 143, 146, 147, 148, 170, 171

Dorado, C. M., Primeras lecturas en Español, 224, 225

Douglas, Stephen, 120

Drake, Francis, 9

Drake, J. R., 207

Dressel and Graff, The New Barnes Readers: Book Three, 207; Book Four, 204

Dunn, A. W., Community Civics for City Schools, 141, 142, 143, 144, 145, 147, $148,149,152,164,165,167,169,170$, 171

Dutch: characteristics of, 180; in the United States, 84

Dyer, F. B., and M. J., Merrill Readers: Fifth, 204, 207; Sixth, 211

Economic problems, textbooks in, 141-77

Ecuador, trade with the United States, 186

Edison, Thomas, 120

Education: American, 99, 109-10; for enlightened voters, 145; free, 189; influence of patriotism on, 253; interest in, 253; for international good will, 251

Eggleston, Edward, First Book in American History, 7, 63, 97, 109, 112, 119

Ellwood, C. A., Sociology and Modern Social Problems, 160, 161, 163

Elson, H. W.: Modern Times and the Living Past, 132, 133, 134, 135; United States: Its Past and Present, 8, 12, 13, $16,19,21,25,27,28,31,35,36,37,39$, $41,45,50,52,56,66,68,74,81,83,90$, $96,97,98,101,104,107,108,110,112$, $113,117,118,119,121$
Elson, W. H., and Runkel, M. H., Elson Readers: Book Two, 196, 207, 210; Book Three, 202, 212; Book Five, 205, 210; Book Seven, 199, 200, 203, 204, 205, 207, 208, 209

Emerson, Ralph Waldo, 204

England: attitude toward colonists, 17, 19; attitude of colonists toward English laws, 15; attitude toward English colonial policies, 21-22; attitude toward United States in Civil War, 42; attitude toward United States in SpanishAmerican War, 46; in World War, 46, 202; characteristics of laws of 1696,1732 , 1750,14 ; characteristics of people, 17778 ; in civics books, $153-56$; in economic and social problems books, 153-56; in European histories, 135; evasion of laws by colonists, 14; exploration, 9 ; in histories, 9-47; immigrants from, 15356 ; impressment of American seamen, $32 \mathrm{ff}$.; parent of American institutions, 47, 202; prevention of trade, 31 ; protection of colonists, 12 ; in readers, 201-5; theory of representation, 17. See American Revolution; Colonists; SpanishAmerican War; World War

English immigrant: characteristics of, 153; common ties between English immigrant and America, 155-56; relations with, during Colonial and Revolutionary periods, 154-55

Eskimos, characteristics of, 180

Esthonians, characteristics of, 180

Estill, H. F., Beginner's History of Our Country, 7, 12, 13, 19, 21, 25, 32, 50, $96,97,114$

Europeans: characteristics of: Belgians, 180; Danes, 180; Dutch, 180; English, 177-78; Eskimos, 180; Esthonians, 180; Finns, 180; French, 178; Germans, 17879; Greeks, 181; Icelanders, 180; Irish, 180-81; Letts, 180; Lithuanians, 180; Magyars, 181; Poles, 180; Portuguese, 181; Russians, 179; Scandinavians, 180; Spanish, 181; Swiss, 179; Turks, 180. See under names of countries

Evans, L. B., The Essential Facts in American History, 5, 11, 12, 13, 15, 19 , $21,25,38,50,59,61,62,63,64,67$, $78,81,82,89,90,100,104,105,112$, 119,121

Exports to the United States. See Trade under names of countries

Fairchild, H. P., Elements of Social Science, 161 
Fairgrieve and Young, Human Geography by Grades, Homes Far Away, Book II, 176, 180

"Famous Protest against the American War, A," 203

Far East, immigrants from: characteristics of, 160; problem of restriction, of, 160-61

"Fatherland, The," 212

Federal Council of the Churches of Christ in America, 252

Federalists, The, 36

Field, W. T., First Reader, 212

Finch, C. E., Everyday Civics, 141, 142, $143,144,145,147,148,149,154,169$, 170,171

Finns, characteristics of, 180

Fish, C. R., History of America, 10, 15, 16, $19,21,23,24,31,32,35,38,41,42,55$, $59,71,78,81,91,93,100,101,103,104$, $112,113,118,120,121$

Fite, E. D.: character of treatment of American Revolution, 15; History of the United States, 7, 10, 15, 25, 27, 34, $40,41,42,45,46,49,57,58,69,74$, $77,78,81,82,90,97,103,104,105$, 107, 109, 118, 119; The United States, $7,19,21,34,35,41,44,51,54,75,76$, $81,82,86,88,93,94,95,99,104,105$, $108,109,118$

Flag. See American Flag

"Flag, The," 207

“Flag Groes By, The," 207

Florida, course of study in, 245, 246, 247

Foreign language, textbooks in, 221-25

Foreign policy of the United States, 100-1; 164-66. See also United States, foreign policy of; Monroe Doctrine; Protectorates

Forman, S. E.: Advanced American History, $3,5,7,10,12,19,21,31,35,40$, $41,44,46,59,63,72,77,81,82,84,85$, $90,91,94,96,97,98,101,112,117$, 118, 119; The American Democracy, $142,144,145,146,147,148,149,152$, 166, 169, 170; First Lessons in Civics, $145,146,148,149$

France: attitude toward American merchantmen, 51; attitude toward, in American readers, 195-97; attitude toward, in European history textbooks, 134; attitude toward, in geographies, 178; attitude of, before War of 1812, 33; characteristics of people, in, 178; colonial policy of, 48; commerce in, 184; in courses of study, 243; descriptions of, 48,49 ; diplomatic negotiations with colonies, 52; effect of descriptions of warfare, 52; in European histories, 134 ; in foreign language books, $222 \mathrm{ff}$.; in French textbooks for public schools, 222-23; immigrants from, 156-57; motives of in allying herself in War for American Independence, 48-50; in the readers, 195-96; traditional friend of United States, 48

Franciscan Sisters of the Perpetual Adoration, A History of the United States for Catholic Schools, 4, 11, 16, 19, 34, 52, $57,69,86$

Franco-German relations: regarding Alsace-Lorraine, 223-24; in 1870, 223; evacuation of Germans after World War, 224

Franklin, Benjamin, 111, 119, 169

Free speech. See American political theories

Freedom: American favorable to, 8; of person, 102; of the press, 102. See American political theories

Frémont, John C., 120

French-English wars: characteristics of, 10; discussion, 10

French immigrants, characteristics of, 156-57

Friends' Peace Committee, 251

Friends' Select School of Philadelphia, emphasis of international idea, in, 251

Fryer, J. E., The Young American Readers Community Interest and Public Spirit, 199

“Fulfillment, The," 200

Garner, J. W., Government in the United States, 145,148

Garner and Henson, Our Country's History, $5,7,11,12,16,24,35,39,40$, $50,52,56,58,62,63,73,78,82,92$, $93,94,98,99,105,109,110,118,119$, 121,125

Garrison, William L., 120

“General Joseph Warren's Address," 204

General character of material in readers, 193-94

Genêt episode, $31,51,52$

Geneva Award, 43

Geography: courses of study in, 242-43; textbooks in, 175-90

George III, 17; characteristics of, 20-21; his program in relation to American colonies, 21-22, 154, 198

Georgia, Manual for Georgia Teachers, $246,247,248$ 
Germans: in attempt to involve the United States in war with Mexico, 73; attitude toward trade with the United States, 185; characteristics of, during colonial period, 55 ; Kultur, 60-61; as immigrants to America, 87, 157-59; methods of warfare during World War, 63-65, 158; and other Europeans, 17879 ; in World War, 60, $133 \mathrm{ff}$.

Germany: in civics, economic and social problems textbooks, 157-59; in geographies, 178-79; in history textbooks, 55-67, $133 \mathrm{ff}$.; in readers, 197-201

Gettell, R. G., The Constitution of the United States, 139, 142, 143, 145, 146, $147,150,151,154,155,165,166$

Gilbert, Sir Humphrey, 9

"Give me liberty or give me death," 203

Gladstone, William, 142

Good Will Day, 248

Gordon, E. K., Fifth Reader, 204, 212

Gordon, E. K., and Stockard, M., Second Reader, 210

Gordy, W. F.: History of the United States, 6, 12, 14, 15, 19, 25, 31, 37, 40, $44,52,58,59,66,72,78,82,86,87,89$, $90,91,92,93,94,95,97,98,101,105$, $109,111,112,114,118,119,121$; Stories of Later American History, 50, $117,118,119,120$

Government, purpose of, 141

Grant, Ulysses S.,' 120

Greeks: characteristics of, 181; as immigrants to America, 162

Greenan and Meredith, Everyday Problems of American Democracy, 142, 143, $144,145,147,148,149,152,157,160$, $164,165,166,168,170$

Greene, F. N., My Country's Voice, 193, 196, 197

Greene, Nathaniel, 118

Guitteau, W. B.: The History of the United States, 14, 19, 21, 25, 32, 35, 46, $58,65,66,70,78,79,81,90$; Our United States, 5, 6, 12, 15, 19, 20, 21, $31,32,35,38,41,44,53,54,57,60$, $61,66,73,76,78,88,91,92,99,100$, $111,112,113,118,121,124,125$; Preparing for Citizenship, 140,141, 145, $146,148,149,151,153,166,169,247$; character of treatment of American Revolution, 15

Hague Conference, 62, 78

"Hail Columbia," 217

Haiti, 98, 166
Hale, Edward Everett, 204, 205

Hale, Nathan, 118, 213

Haliburton, M. W.: Fourth Reader, 204; Fifth Reader, 203, 204, 205, 210

Hall, Smither, and Ousley, History of the United States, 7, 25, 26, 28, 32, 34, 37. $38,41,50,52,57,59,73,78,89,93$, $96,97,98,109,117,130$

Halleck, R. P., History of Our Country, $7,8,10,15,21,25,27,34,36,41,49$, $50,58,59,62,71,77,82,93,96,97$, $99,105,110,112,113,115,119,121$

Halleck and Frantz, Our Nation's Heritage, 110, 111, 118, 119

Hamilton, Alexander, 119, 169

Hancock, John, 154

“Happy Is Our Soldier Band," 219

Harrison, Benjamin, 212

Hart, A. B.: New American History, 9, $19,21,24,35,48,52,69,78,89,91$, 100, 112, 118, 119; School History of the United States, 19, 21, 34, 36, 40, 42, $52,74,84,87,90,93,97,103,104,108$, $113,118,119$

Hart, J. K., Social Life and Institutions, 144

Hartwell, E. C., Story Hour Readings: Fourth Year, 204, 205, 210, 213; Fifth Year, 199, 200, 204, 205, 208, 210; Sixth Year, 203, 204, 205, 206, 208, 211, 212; Seventh Year, 203, 204, 205, 212; Eighth Year, 205, 206, 213

Haviland, Walter W., principal of Friends' Select School of Philadelphia, 251

Hawaiian Islands, 95-96

Hawthorne, Hildegarde, 212

Hawthorne, Nathaniel, 204, 205

Hay, John, 120

Hayes, B. T., American Democracy, 141, $143,146,147,148,154,156,159,165$, 168,169

Hayes, C. J. H., 253

Hayes and Moon, Modern History, 132, 133, 134, 135

"Hear O Ye Nations," 221

Heath Readers: Fourth Reader, 212; Fifth Reader, 205, 209; Sixth Reader, 204, 206, 207

Hemans, Felicia, 206

Henry, Patrick, 24, 117, 169

Hepner, W. R., and F. K., The Good Citizen, 141, 142, 144, 145, 154, 162

Herkimer, General, "the hero of Oriskany," 118 
Heroes: in courses in history, 247; description of, 36, 114, 117-21, 188-89

Hervey, W. L., and Hix, Melvin, Horace Mann Readers: Fourth Reader, 207; Fifth Reader, 203, 204, 205, 209, 210; Sixth Reader, 203, 204, 205, 213; Seventh Reader, 205, 207, 209; Eighth Reader, 203, 204, 205, 209, 212, 213; Introductory Fourth Reader, 208

Hessians, 55

Hill, H. C., Community Life and Civic Problems, 144, 145, 147, 152, 160, 168

Hill, Mabel, Lessons for Junior Citizens, 170

Hindus, as immigrants to America, 161

Hirshfield, David, 13

History: courses of study in, 246-49; textbooks in, 3-141

Holmes, Oliver Wendell, 207

Horne, C. F., The Story of Our American People, 3, 4, 7, 8, 10, 12, 15, 16, 20, 21, $23,24,25,27,28,32,34,35,38,40$, $42,44,46,51,53,59,66,71,73,74,75$, $79,82,84,91,94,97,102,103,105,107$, $109,110,111,113,114,115,117,118$, 119,121

Houston, Sam, 120

"How Andy Helped To Capture the Redcoats," 202

Huerta, 73

Hughes, R. O.: Community Civics, 149; Economic Civics, 142, 144, 145, 146, 147, $148,149,152,154,166,167,170 ;$ New Community Civics, 139, 141, 144, 145, 146, 170; Text-Book in Citizenship, $141,144,145,146,147,152,161,163$, $167,169,171$

Huguenots, as settlers, 48

Hulbert, A. B., United States History, 8, $11,16,19,21,34,35,41,45,46,55$, $57,72,79,81,90,91,93$

Huntington, Ellsworth, Asia, 175, 178, $179,180,181,182$

Hyde, Modern Biography, 251

Ibañez, Blasco, Vistas Sudamericanas, 224,225

Iceland, characteristics of people in, 180

Idaho: Courses of Study for Public Schools, 247; Manual and Courses of Study for High Schools, 246

Immigrants to United States: contributions of, 151; duties of, to U.S., 88; economic effect of, 152; English, 15356; Germans, 157-59; Irish, 84-85; Italians, 162; loyalty in World War,
152; Mexicans, 163; oriental, 159-60; political ideas of, 152; Southern and Eastern Europe, 161-63. See under different nationalities.

Immigration, 86-88, 151-63. See Immigrants

Imports from the United States. See trade under names of countries

Impressment of American seamen. See War of 1812

"Independence Bell," 204

Indian, the: characteristics of, 91; policy of the United States government toward, 91-92, 163

Indianapolis, Course of Study in American Citizenship, 251

"In Flanders Field," 199

International attitudes in some European history textbooks, 131-35

Iowa, Course in American Citizenship, 244

Irish: in Catholic histories, $85 \mathrm{ff}$.; characteristics of, 85, 180; immigrants, 8485; sentiment in the United States toward, 85-86

Irving, Washington, 205

Italians: characteristics of, 179; as immigrants to America, 162; in Italian textbooks used in American schools, 225; trade with the United States, 185

“Jabez Rockwell's Powder Horn," 202

Jackson, Andrew: at Horseshoe Bend, 38; in Mexican situation in 1837, 69, 120,169 ; in spoliation claims, 51 ; his victory at New Orleans, 39

James and Sanford: American History, $15,19,21,34,43,91,96,117$; character of treatment of American Revolution, 15

Jamestown, 9

Japanese: characteristics of, 175, 182; early progress of, 181; sending of dolls to children of, by school children of America, 252; trade with the United States, 186

Japanese-American relations, 82-83; Perry's visit to Japan, 82; restriction of Japanese to the United States, 83, 161; United States in Russo-Japanese War, 82

Jay, John: quoted, 49; treaty, by, 32, 51-52

Jefferson, Thomas, 84; in Chesapeake and Leopard Affair, 37, 119, 205 
Jenks and Smith, We and Our Government, 140, 141, 142, 145, 146, 148, 153, $157,160,162,168,170$

Jews, as immigrants to America, 162-63

Joan of Arc, heroic figure of French textbooks, 222

“Joan and Pierre," 196

Joffre, visit of, to United States, 53

Jones, John Paul, 118, 169, 205

Jones, William, 212

Junior Red Cross, 252

Kaiser Wilhelm, 198

Keller, William H., 210

Knowlton, P. A., First Lessons in Geography, 188, 190

Kultur, German, 60, 61

Labiche and Martin, Le voyage de Monsieur Perrichon, 222

Lafayette, 50, 53, 196

Lake County, Indiana, social studies course, 250

"Landing of the Pilgrims, The," 206

Lane, Franklin L., 208

Lansing and Jones, Government in State and Nation, 141, 142, 143, 144, 149, 154

Lapp, J. A., Our America, 141, 142, 143, $145,146,165,169$

Latané, J. H., A History of the United States, 5, 13, 21, 24, 34, 41, 45, 46, 58, $59,81,118,119$

Latvia, characteristics of people in, 180

Lavisse, Ernest, Histoire de France, 222, 223

Lawler, T. B., Essentials of American History, 11, 16, 19, 21, 32, 41, 78

Laws, $229 \mathrm{ff}$.; citizenship and loyalty of teachers, 237-39; the curriculum, 22932; observance days, 239-41; textbooks, 232-34; use of English and foreign language, 234-37

Lee, Charles, 119

Lee, Robert E., 120

Lefferts, Walter, Our Own United States, 188

Leger, Sir William, 118

Lenine, 78

"Leon and Marcel," story of, 195-96

Leonard and Jacobs, The Nation's History, $7,19,20,32,34,40,50,56,73,81$, $82,88,94,97,104,105,110,119$

"Let Dread War Cease," 221

"Let Peace Endure," 221
Levis, E. C., Citizenship, 141, 142, 144, 146, 148, 149

Lew, Timothy T., "China in American School Textbooks," 80

Lewis and Clark, 120

Lewis and Rowland, The Silent Readers: Fourth Reader, 196; Fifth Reader, 196, 205; Seventh Reader, 198, 205, 212; Eighth Reader, 195, 197, 199, 200, 201, 208, 211, 212

"Lexington and Concord," 203

Liberty: concept of, in study of the Revolution, 29-35; preservation of, 103

Lincoln, Abraham, 111, 120, 169, 212

Lithuania, characteristics of people in, 180

Locke, John, 24

Long, J. R., Government and the People, $141,145,163,167,168$

Long, W. J., America, 7, 10, 11, 15, 16, $23,25,28,29,31,38,39,41,48,51$, $53,59,66,67,69,71,72,77,90,91$, $92,93,94,96,98,99,104,106,107$, $108,113,116,121$

Longfellow, William W., 204

Louisburg, return to France, 11

Lowell, James Russell, 212

Loyalists. See Tories

Loyalty. See Patriotism

Lusitania, 60, 65, 158-59

Lyman and Hill, Literature and Living: Book Three, 207, 208, 212, 213

McCarthy, C. H., History of the United States for Catholic Schools, 5, 7, 19, 21, $25,39,58,72,73,78,86$

McClenahan, P. C., Course in American Citizenship, 244

MacDonough: superiority of American seamanship, 39; victory of, on Lake Erie in 1814, 39

McKinley, William, 120

McLaughlin, A. C.: character of treatment of American Revolution, 15 ; History of the American Nation, 3, 7, 8, 15, $19,21,22,23,25,31,34,40,42,46$, $49,51,52,59,63,75,78,81,89,94$, $97,101,103,104,105,113,118$

McLaughlin and VanTyne, A History of the United States for Schools, 11, 19, 21 , $34,39,42,49,52,56,70,71,90,95$, $96,100,118$

McManus and Haaren, Natural Method Readers: Third Reader, 202, 205, 207; Fifth Reader, 204 
McMaster, J. B., A School History of the United States, 7, 10, 11, 21, 25, 36, 40, $43,50,52,95,97,99,119$

McMurry and Parkins, Advanced Geography, 177, 178, 179, 180, 181, 182, 183, $184,187,189,190$

McNeal, E. H., Modern Europe and Its Beginnings, 132, 133, 134

Mace, W. H.: Primary History of the United States, 117, 118, 120; School History of the United States, 6, 11, 19, 21, $25,35,40,44,52,53,56,72,79,82$, $88,97,99,100,119$

Mace and Bogardus, History of the United States, 7, 10, 11, 19, 21, 32, 35, 39, 41, $42,49,52,59,69,71,73,74,78,82,84$, $88,90,91,94,98,101,104,105,110$, $112,118,119,121,123,125$

Macy, Arthur, 208

Madison, James, 33, 34, 35, 119, 169

Magna Charta, 143, 154

Magruder, F. A., American Government in 1923, 141, 142

Magyars, characteristics of, 181

Mairet, La Tâche du petit Pierre, 223

Majority Rule, 147 ff.

"Makers of the Flag, The," 208

"Man without a Country, The," 213

Manila, episode of, 58

“Marching Song of Stark's Men, The," 204

Marion, 26, 118, 203

Marshall, John, 120, 169

Maryland, Baltimore schools, course of study in, 249

Mason and Slidell, capture of, 43

Massachusetts: bulletin, 246; Plan for the Study of the Constitution, 246; Teachers' Manual of the United States History for Grades 7 and 8, 247

Mavity, A. B., and N. C., Responsible Citizenship, 143, 144, 145, 146, 149, $155,156,160,161,163,165,167,168$, 169

Maximilian Affair, 53

Mayflower Compact, 103, 143-44

Menendez, attack on Ribaut, 4-5

Méras and Roth, Petits contes de France, 222, 223

Mercantile theory, 16

Merimée, Colomba, 223

Metternich, 132, 134

Mexico: characteristics of people, 71-72, 163, 183; French desire for territory in, 53; government of, 163; immigrants from, 163; Santa Anna, president of, 71; and the United States during Wilson's administration, 72-73; war with the United States, 69-72, 163

Military Order of the World War, the, 123

Minnesota, Curriculum for Elementary Schools, 243

Minority opinion, $147 \mathrm{ff}$.

"Minute Men of '76, The," 204

Mirick, G. A., Home Life around the World, 179

Mississippi: Department of Education Bulletin, 246; high schools, 246

Missouri, course of study in, 243, 244-45, 247,248

Molasses Act, 14

Monroe Doctrine: Anglo-American relations regarding Venezuèlan boundary dispute, 42, 44, 45, 53, 59; effect of its declaration on American people, 100-1, 158; as phase of United States foreign policy in dealing with European powers, 74 ; protectorates, 166,189 ; purpose of, $74,164-65$; in relation to Russia, 77, 98

Monroe, James, 120, 164

Monroe and Miller, The American Spirit a Basis for World Democracy, 205

Montana, course of study in, 243, 246

Monvert, A. de, La Belle France, 222, 223

Morehouse and Graham, American Problems, 145, 149, 162, 167, 168, 170, 171

Morgan, D. S., Living and Working Together, 141, 143, 145, 148, 154, 170

Morgan, General, 118

Morris, Charles, Home Life in All Lands, Book $I, 175$

Morris, Robert, 119, 205

Munro, W. B., Current Problems in Citizenship, 140,142,143, 145, 147, $148,152,155,157,160,161,166,168$, 170

Munro and Ozanne, Social Civics, 140, $141,142,143,144,145,146,147,143$, $149,151,155,160,161,163,164,165$, $166,170,171$

Music: textbooks in, 217-21; elementary, 218; upper grades and high school, 219

Muzzey, D. S.: An American History, $3,7,11,14,15,16,19,20,21,22,23,24$, $25,31,34,36,38,40,41,42,46,48,49$, $57,59,62,69,71,73,78,81,84,89,90$, 91, 93, 95, 110, 112, 118, 119, 121; History of the American People, 3, 6, 7; criticism of, 13

"My Country," 217 
Napoleon, 51, 77, 134, 135; as a heroic figure in French textbooks, 222; relations with colonies, 52

National Education Association, 248, 249

Nationality, meaning of, 116

Natural rights, doctrine of, 24, 143

Naval war of 1798, 50

Navigation laws, 13, 15

Negro: in America, 89-91; characteristics of, 90-91; problem of, 163; treatment of, in textbooks, $89 \mathrm{ff}$., $163 \mathrm{ff}$.

Nelson, Ernesto, Spanish American Reader, 225

Nesbit, Wilbur, D., 207

Neutrality Act, 31

"New American Hymn," 217

New Mexico, course of study, 242

New York: civics courses, in, 250; elementary schools, 246; report of textbooks used in city schools, 13

Nicaragua, 98, 166

Nicholson, Meredith, Heart of America Readers: Third Reader, 209, 210, 211; Fourth Reader, 203, 204; Fifth Reader, 206, 208

Nida, W. L., The Dawn of American History in Europe, 6, 48

Northwest Ordinance, 103

O'Hara, J. P., A History of the United States, 10, 11, 19, 21, 35, 39, 73, 121

Oklahoma, course of study, 244, 246

"Old Bay," 202

Opportunities for foreigners. See United States, the land of opportunity

Oregon: reports concerning, 42; state course of study, 246, 248; treaty in regard to, 41

Otis, James, 16, 119

"Our Mutual Interests," 201-2

"Our Native Song," 217

Packard and Sinnott, Nations as Neighbors, 176, 177, 179, 180, 181, 182, 184, 189,190

Pan-Americanism, 75, 165

Pan-American Union, 75, 190

Panama Canal region, $96 \mathrm{ff}$.

Panama revolt, 75, 97

"Parade, The," 220

"Patriot of Georgia, A," 202

Patriotism: characteristics of Americans, $114-15,130$; in courses of study in history, 246; in music textbooks, 221; questionnaire a mong school children on, 124-30

"Paul Revere's Ride," 204

Peace of Paris, 31

Penn, William, 119, 205

Pennsylvania, Manual and Courses of Study for Elementary Schools, 243, 246, 247, 248

Perdue, H. A., Child Life in Other Lands, 180

Perry: victory of, on Lake Erie, 38; description of American fighting, 38

Pershing, John, 120

Peruvians: characteristics of, 183; trade with the United States, 186

Petition of Right, 143, 154

Petition, right of, 102. See American political theories

Philippines: American work in, 94-95; dependency of the United States, 93-95

Pierce, B. L., Public Opinion and the Teaching of History in the United States, 14, 230

Pierpont, John, 204

Pinchot, Gifford, 120

Pinckney, 51

Pitcher, Molly, 205

Pitt, William, 29, 203

Platt Amendment, 93

"Playing Soldier," 220

"Pledge, The," 199

"Pledge of the Athenian Youths," 210

"Pledge to the Flag, The," 210

Poland, characteristics of people in, 180

Political parties, affiliation with, 147

Political problems, textbooks in, 141-77

Political rights. See American political theories

Political theories. See American political theories

Porto Rico, 95

Portuguese, characteristics of, 181

Pratt, M.L.: America's Story for America's Children, 25; Stories of Colonial Children, 206

Preparedness, as treated by textbook authors, 99, 121, 170

Proclamation Line of 1763, 16

"Promised Land, The," 113

Property holding, right of, 102

Prosperity. See United States, advantages of, land of opportunity 
Protectorates of the United States, 98. See Caribbean, Monroe Doctrine, Foreign policy of the United States

Public officials: characteristics of, 104-5, 146; duty of, 105, 146

Public opinion, 145

Public and the School, The, quoted, 252

Public school curriculum, 250

Pupils: in schools, attitude toward the United States and foreign countries, $128 \mathrm{ff}$; toward patriotism, $125 \mathrm{ff}$.

Puritans, reasons for migration to the United States, 10

Putnam, Israel, 118

Quaker schools, Courses of Study, in, 251

Racial elements in the United States, 8492

Raleigh, Sir Walter, 9

Readers: England in, 201-4; France in, 195-97; general character of materials in, 193-94; Germany in, 197-201; United States in, 207-13

Reconcentrados, 7

"Red Coats," 202

Reed, T. H., Loyal Citizenship, 141, 142, $143,144,146,147,149,152,166,169$, 170,171

Religious freedom, 102, 167, 250. See American political theories

Representation, theory of, 17-21

Republicans, 36

Revere, Paul, 24, 118, 204

Rexford and Carson, The Constitution of Our Country, 142, 144, 146, 148, 154, 168,170

Ribaut, attacked by Menendez, 4-5

Robbins, C. L., School History of the American People, 8, 11, 19, 21, 32, 46, $58,59,62,73,78,90,92,93,94,97$, 99,$100 ; 101,105,109,118$

Robertson, James, 120

Robinson, E. V., Commercial Geography, $177,178,179,180,182,183,184,189$, 190

Robinson, J. H., 256

Rochambeau, 53, 196

Roosevelt, 59, 75, 96-97, 109, 120, 169

Root, Elihu, 120

Rugg, Harold, The Social Science Pamphlets $I, 91,110,112,113$

Rush-Bagot Agreement of 1817, 41
Russia and the United States, during the Civil War, 77-78; attitude toward, in European history textbooks, 134

Russians, characteristics of, 179; trade with the United States, 185

Russo-Japanese War, 82

St. Louis Schools, Social Studies Curriculum Bulletin, 249

Samoan incident, 56, 57-58

Santa Anna, president of Mexico, 71

Santo Domingo, 98, 166

Scandinavians, characteristics, 180

Schleswig and Holstein, 62

Scotch and Irish in the United States, 8486

Scott, J. F., The Menace of Nationalism in Education, 124

Seal fisheries: arbitration of, 44; controversy of, 44

Searson, Martin, and Tinley, Studies in Reading: First, 205, 210; Third, 210, 212

Secular institutions, characteristics of courses in social studies, 252

"Sergeant, The," 218

Seward, William, 120

Shepherd, W. G., The Boy's Own Book of Politics, 145, 146, 147, 171

Sioux City, Iowa, courses of study in, 250

Slavery, negro. See Negro

"Smallest Soldier of All," 196

Smith, C. J., The Easy Road to Reading: Third Reader, 207

Smith, Eleanor, Music Course: Book One, 220; Book Three, 218; Book Four, 217, 220

Smith, Goldwin, 43

Smith, John, 119, 205

Smith, J. R., Human Geography, Book I, 177, 178, 179, 183, 188; Human Geography, Book II, 176, 177, 179, 180, 181, 182, 184, 189

Social contract, theory of, 143

Social problems, textbooks in, 141-77

Sociology, textbooks in, 141-77. See Social problems

"Soldier Song," 220

"Song of Marion's Men," 204

Songs of Childhood, 220

Sons of the American Revolution, 13

South America: characteristics of people in, 183; increasing trade of, with North 
America, 76, 184; Monroe Doctrine in, 74; relations with the United States, 74-76

South Dakota, High School Manual, 246

Southworth, A. T., The Common Sense of the Constitution of the United States, $143,149,154,169$

Spain: in Catholic histories, 5 ; cause of the United States intervention in behalf of Cuba in 1898, 6-8, 181; characteristics of, during period of exploration, 3-4; colonial policy of, 5-8; credit for discovery of new world, 3 ; in histories, 3-6; in incident of Menendez and Ribaut, 4-5; in Protestant histories, 5; in Spanish textbooks, 224

Spanish-American War, attitude of European Powers, $8,46 \mathrm{ff}$.; causes of, 6 ; comparison of Spain and United States, 8; influence in making United States world-power, 164

"Speed Our Republic," 217

"Spirit of Peace, The," 221

Spoils system, 105, 146

Stamp Act, 15, 16

"Star Spangled Banner, The," 217

Stark, John, 118

Stephenson, N. W., and M. T., A School History of the United States, 9, 19, 21, $25,26,28,35,41,42,43,46,50,59$, $62,63,71,82,87,96,97,108,109,112$, $118,119,121,122$

Steuben, Baron von, 56

Struggle between France and England in the eighteenth century: French and Indian War, 11-13; return of Louisburg to France, 10-11

Submarine. See Germany

Suffrage, exercise of, 144-45

Sugar Act, the, 14-15

Sullivan, Mark, Our Times: The United States 1900-1925, Vol. I: The Turn of the Century, 58

Sumter, 118

Swiss: characteristics of, 179; trade with United States, 185

Syrians, as immigrants to America, 162

Tappan, E. M., American Hero Stories, 119

Tarr and McMurry: New Geographies First Book, 176, 177, 181, 182, 188, 189, 190; New Geographies Second Book, $178,179,180,182,190$

Taxation, 19-20, 148 ff. See Citizenship
Taylor, Zachary, 71

"Tea Party, A," 203

Teacher of history, influence of, 30

Texas, independence of, $\mathbf{7 0}$

Textbooks: characteristics of, 16, 30, 254-56; critics of, 24 ; influence of contents on readers, 254; political concepts in, 255; treatment of different nations, 254-55. See History, Geography, etc.

Thomas, A. A., 248

Thompson, C. M., History of the United States, Political, Social, and Industrial, 108

Thompson, Waddy: First Book in United States History, 7, 16, 21, 27, 34, 62, 86, 88, 97, 101, 108, 119, 121; A History of the People of the United States, 5, 6, $10,11,16,19,26,32,35,39,40,41$, $45,52,58,63,72,77,86,93,96,97,112$, $118,121,125$

Thwaites and Kendall, A History of the United States, 11, 19, 20, 41, 44, 56, $62,65,69,77,87,93,94,96,105,109$, $110,118,119,121$

Tories, 22-23, 30

Towne, E. T., Social Problems, 160, 161

Trade among nations, 184-87; influence of transportation on, 176

Transportation, influence of, on interdependence of nations, 176

Treaty of Washington, 43

Trent Affair, English recognition of, 43

Trial by jury, 102

Triple Alliance, 62

Trotsky, Leon, 78

“True Patriotism," 212

Tryon and Lingley, The American People and Nation, 6, 7, 21, 34.

Turkey, 134

Turkington, G. A.: Community Civics, $141,145,146,167,168,170 ; M y$ Country, 141, 149, 153, 156, 158, 163, $167,168,169,170,171$

Turks, characteristics of, 180

"Union and Liberty," 207

United States: amusements in, 109; attitude toward, by foreign nations, 9; climate of, 188; defense from foreign countries, 169-70; dependencies of, 9399; education, 109, 189, 211, 250; foreign policy of, 100-101, $164 \mathrm{ff}$.; freedom from military requirements, 167; government of, 123, 144, 250; humanitarianism, 110-11, 125; in- 
vincibility in arms, $36,38,39,40,122$, 169,171 ; land of opportunity, 107, 111, $113,116,167,188 \mathrm{ff} ., 211$, 250; literature in, 109; peace advocate, 124, 170; political and religious freedom, 167, 250; natural resources, 188-89; social ideals in, 125; world-minded, 111. See America, Americans

United States, Bureau of Education, 248

Utah, course of study, 243, 247, 248

Valley Forge, effect of description of, 26

Van Horne, John, Il Risorgimento, 225

Venezuelan boundary dispute: effect of, on Anglo-American relations, 44-45;

Germany refuses arbitration in, $\mathbf{5 9}$

Venezuelans: characteristics of, 183; trade with the United States, 186

Villa, 73

Viviani, visit of, to United States, 53

Vollentine, Grace, The Making of America, 52, 70, 109, 112

War: in civics books, 170; in histories, 121; in music textbooks, $218 \mathrm{ff}$; in the readers, 212. See Preparedness

'War Hawks," 35

"War's Recompense," 200-201

War of 1812, 35-40; causes of, 35, 36; cost of, 40 ; descriptions favorable to the United States, 40 ; results of, 40 ; timeliness of, 35

Washington, Booker T., 90

Washington, D.C., burning of, 38-39

Washington, George, 23, 53, 56, 100, 111 , $118,120,154,165,169,202,212$

Wayne, Anthony, 118

Webster, Daniel, 120, 169, 204

Webster-Ashburton Treaty, latent British-American feeling aroused, 42

West, W. M.: character of treatment of American Revolution, 15; criticism of, 13; History of the American People, 14, $15,16,21,23,34,35,36,39,40,41,49$, $50,52,58,63,64,65,69,72,97,121$; World Progress, 131, 132, 133, 134, 135

West and West, The Story of Our Country, $7,10,15,19,21,24,25,26,35,36,41$, $42,44,45,86,87,89,90,94,97,98$,
$99,100,108,109,110,113,116,118$, 121,125

Weyler, General, 6-7

"What Constitutes a State," 212

Whigs, 23

Whitbeck, R. H., High School Geography, $176,177,178,179,182,183,184,185$

White, H. A., Beginner's History of the United States, 7, 71, 104, 117, 118

"Who Patriots Are," 212

Wilkins and Marinoni, L'Italia, 225

Williams, Roger, 119

Williamson, T. R., Problems in American Democracy, 139, 140, 143, 145, 146, 147

Wilson, President, in Mexican situation, 72-74, 120

Winthrop, John, 119

Wisconsin, course of study, 243, 246

Withers, Sarah, and others, The Child's World: Second Reader, 211

Woodburn and Moran: The Citizen and the Republic, 139, 142, 143, 145, 146, $147,149,151,156,158,159,162,164$, 165, 168, 171; Elementary American History and Government, 6, 12, 19, 21, $22,23,24,25,26,31,35,42,63,65$, $68,76,78,88,96,97,98,99,104,109$, $112,113,118,119$

World Federation of Education Association, in teaching history, 248

"World Peace," 220

World War: background of, 61; cause of, 62; characteristics of Germans, 60; characterizations of belligerants, 64, 178-79; for democracy, 66; England an ally of United States in, 46; motives of German invasion, 61; stories of, 195-97; United States aids France in, 53

Writs of Assistance, 16

XYZ affair, 52

"Yankee Doodle," 217

"Your Best and Hardest Job," 212

"Your Flag and My Flag," 207

Ziegler and Jacquette, Our Community, $139,141,143,144,145,147,148,149$, 170,171

Zimmerman note, 65 






